\title{
Aiding science Swedish research aid policy 1973-2008
}

\author{
Veronica Brodén Gyberg
}

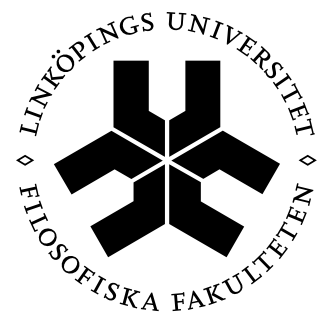

Linköping Studies in Arts and Science • No. 594

The Department of Thematic Studies - Technology and Social Change Linköping 2013 
Linköping Studies in Arts and Science • No. 594

At the Faculty of Arts and Science at Linköping University, research and doctoral studies are carried out within broad problem areas. Research is organized in interdisciplinary research environments and doctoral studies mainly in graduate schools. Jointly, they publish the series Linköping Studies in Arts and Science. This thesis comes from The Department of Thematic Studies - Technology and Social Change.

Distributed by:

The Department of Thematic Studies - Technology and Social Change Linköping University

58183

Veronica Brodén Gyberg

Aiding science. Swedish research aid policy 1973-2008

Edition 1:1

ISBN 978-91-7519-481-3

ISSN 0282-9800

(C) Veronica Brodén Gyberg

The Department of Thematic Studies - Technology and Social Change 2013

Printed by: LiU-tryck, Linköping 2013

Cover by: LiU-tryck (photo by Olle Edqvist)

The photo collages are made up of images from Sarec's annual reports 


\section{Table of contents}

\section{Acknowledgements ................................................................................6}

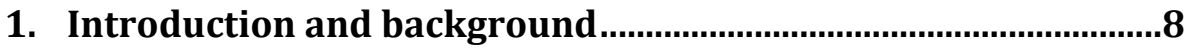

The object of study: Swedish research aid policy ................................................................ 10

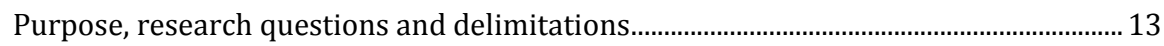

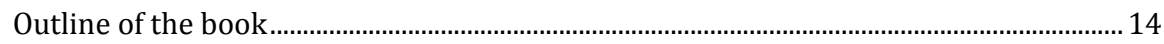

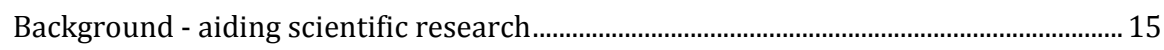

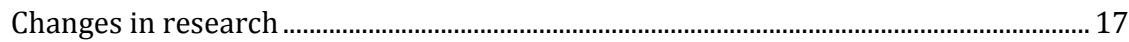

Theories about science (technology) and policy ............................................................ 19

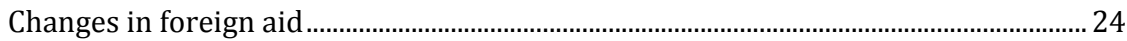

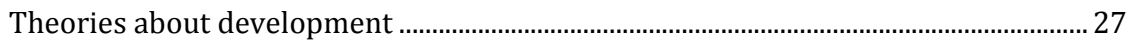

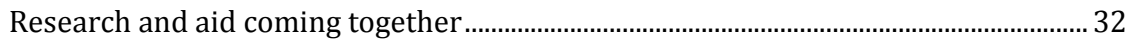

Research aid - symptomatic of the "knowledge society?" ................................................ 34

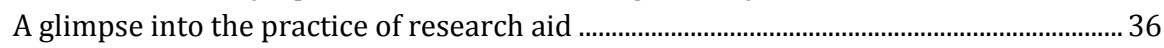

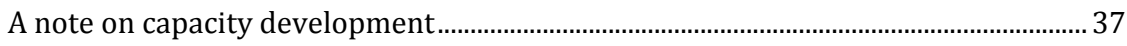

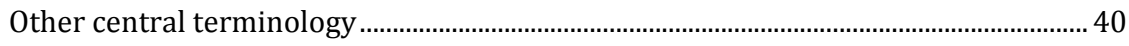

2. Theoretical perspectives.................................................................41

Framing the construction of research aid- theories of discourse ...................................... 42

Discourse according to Foucault.................................................................................... 43

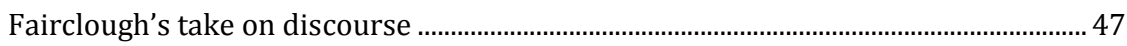

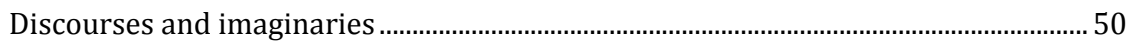

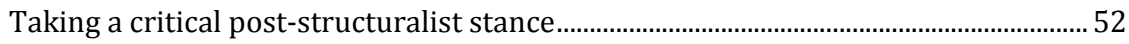

Science and Technology Studies and colonialism(s) ........................................................... 55

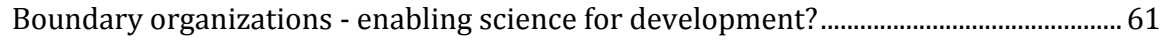

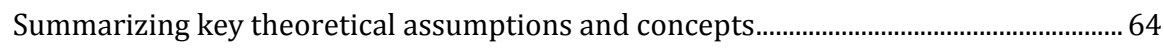

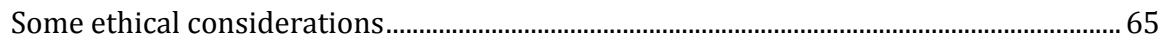

3. Methods and materials ..............................................................68

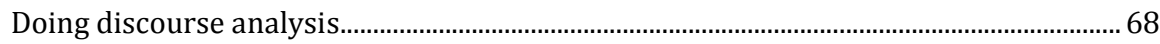

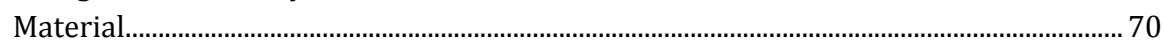

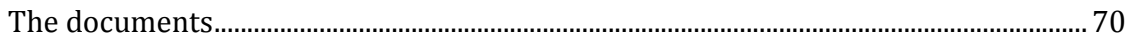

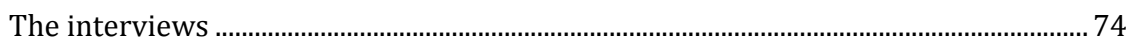

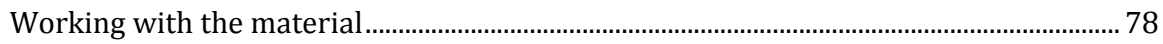

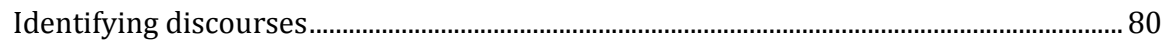

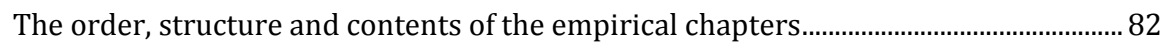

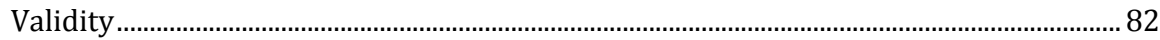

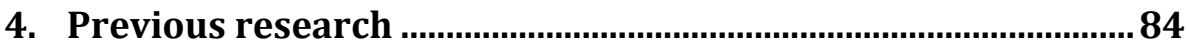

Foreign aid: wanted dead or alive? Questioning aid efficiency ........................................... 86

Research aid: some general trends in the literature ............................................................ 90

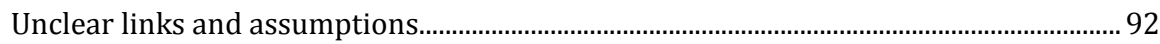

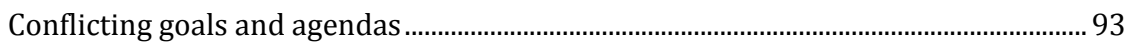


Mutually beneficial cooperation or neocolonial science? .............................................. 95

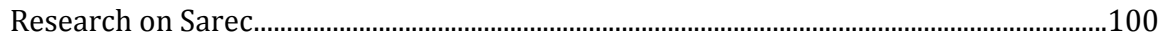

Concluding reflections and the contribution of this study .............................................106

5. 1973-1979: Tracing foundations .............................................. 109

Swedish research-related aid before Sarec: setting the scene.........................................111

Research for Development - the 1973 investigation report ..............................................112

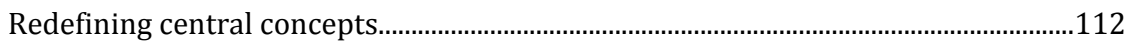

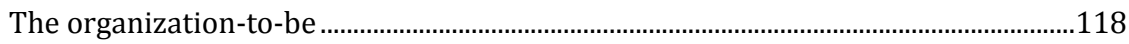

Economists protest. A battle to define the problem and its solution. .........................121

Sarec takes form..............................................................................................................124

Interpreting the task. The first annual reports. ...........................................................124

Modes of support: old and new priorities .....................................................................127

Renewed economist protest............................................................................................131

From research to development through aid ......................................................................133

Sarec as the context-sensitive and emancipatory donor..............................................133

Sarec as a temporary provider of priorities and expertise............................................135

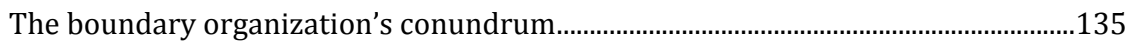

Concluding discussion: discourses and tensions between them .....................................136

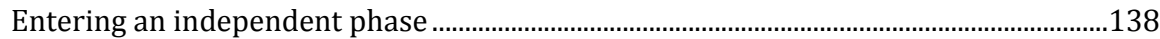

6. 1981-1990: Settling in and becoming pragmatic .................. 141

Attempting to construct a more pragmatic and concise task ..............................................143

The 10 year evaluation: questioning models and measures .............................................144

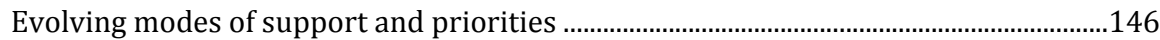

The battle to define development problems and their solutions. Part 2: converging

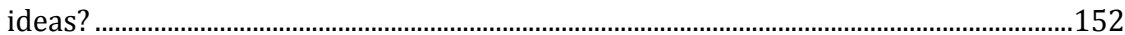

Bilateral cooperation as a way to build national capacity ............................................154

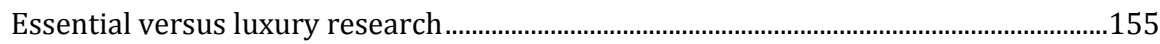

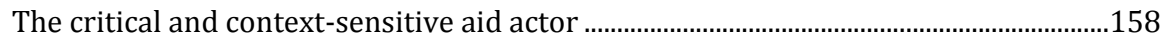

Questioning agenda-setting while setting the agenda .....................................................161

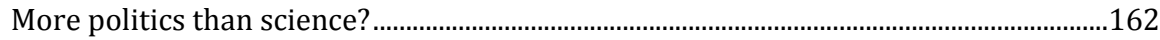

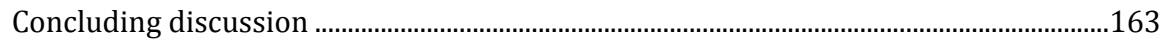

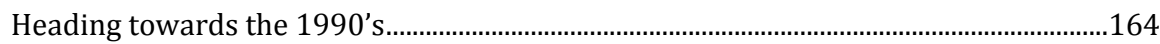

7. 1991-1997: Revival and change............................................ 167

The "Sarec model" - evolving modes of support and priorities ........................................169

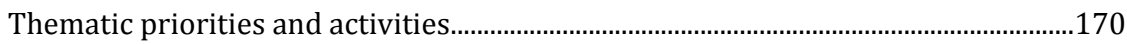

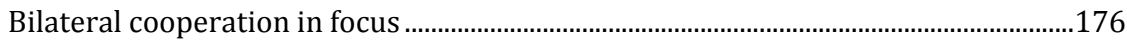

20 years of existence; taking stock and "returning" to Sida................................................182

One research university per country ..........................................................................185

Framing horizontal research as key to sustainable development...................................188

Localist universalism? The branches grow closer ..............................................................190

Concluding discussion. Dependency as a way to independence? .....................................191 


\section{1998-2008: Constructing sustainable knowledge societies.. 195}

The wider social practice - a snapshot ………....................................................................196

Sarec within Sida. Building new capacities?.........................................................................198

Localist universalism continued. Evolving modes of support and priorities.................204

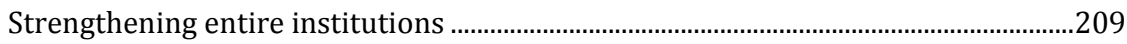

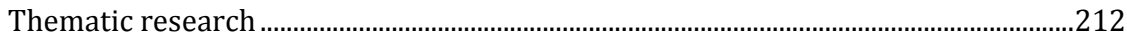

Reducing poverty through sustainable development ........................................................213

Imagining research within innovation-systems for development ...................................216

The picture of the aid actor: unique, context-sensitive and empancipatory .................220

Sarec within Sida. Embracing change while resolutely defending boundaries between

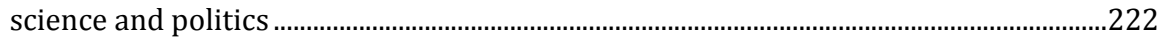

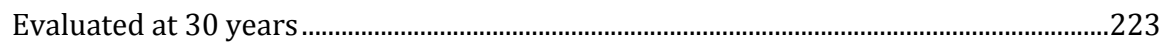

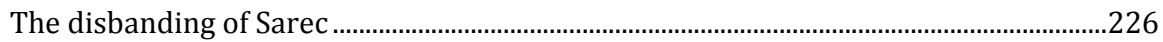

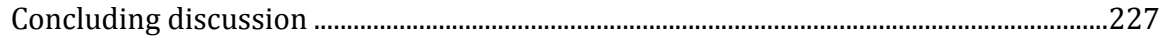

9. Concluding discussion: the boundary organization's

conundrum ............................................................................................ 229

Four decades of science aid. Negotiating capacities and imagining research for

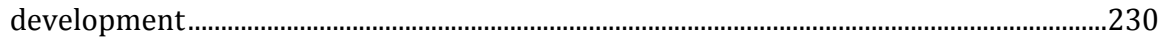

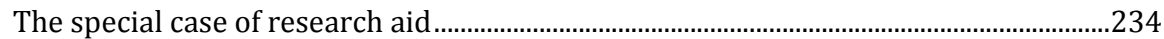

EPILOGUE: Imagining futures post-2008 …..................................... 238

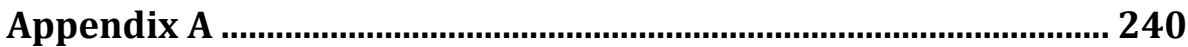

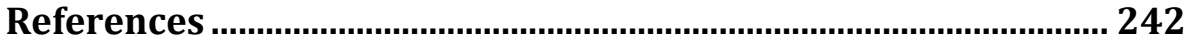




\section{Acknowledgements}

I am very happy to be sending this book to the printers, and I am extremely grateful to the environments and people who made it possible. My main supervisor along this whole journey has been Sven Widmalm. You have encouraged my interests from day one by being been consistently positive, supportive and always available with great questions, opinions, critique, honesty and a great sense of humor. There should be more Svens in academia in my opinion, and I look forward to continued cooperation with you! My first co-supervisor Olle Edqvist unfortunately passed away in 2011, and I am very sad that he is no longer with us. I am grateful that he gave me the chance to thank him for all his good ideas, advice, detailed readings, encouraging words and excellent conversations about life in general. Thank you so much again. Eva Lövbrand, my current co-supervisor: your perspectives and ideas have greatly enriched my writing and I have found our conversations really challenging and inspiring every time. I'm happy our paths crossed and hope that they will keep doing so. I feel truly privileged to have had you all as my supervisors!

The study I have conducted was very interesting when it was just me and the documents, but it became even more interesting as I started interviewing all the former directors of Sarec. You greatly improved my understanding of research aid and provided many new angles to think about, thank you for your time!

Thank you C-F Helgesson, Isabelle Dussauge and Wiktoria Glad for constructive comments at my 60\%-seminar. The next big deadline, my final seminar, was a very interesting and productive experience thanks to Aant Elzinga, Per-Anders Forstorp, Ericka Johnson and Johan Hedrén. You gave me the feedback I needed to take on the last part of this trip with energy and inspiration. A special thanks to Aant for the excellent job you did, you helped me see things from several new perspectives!

Many chapter drafts have been discussed in TVOPP and towards the end also in TPI/P6 and Green Critical Forum. A special thanks to Jonas Anshelm, Vasilis Galis, AnnSofie Kall, Julia Schwabecker, Per Gyberg, Simon Haikola, Hanna Sjögren, Anders Hansson, Johan Hedrén and Boel Berner for your helpful comments during these seminars.

It's been very rewarding to work with all the excellent staff and ambitious students in several inspiring teaching contexts, not least the environmental science program (miljövetarprogrammet) where I spent most of those hours, but also other places. I have thoroughly enjoyed the cooperation with other colleagues "in class", in the corridors and at meetings. The experiences have all enriched my perspectives and helped me to think better about both teaching and doing research.

Thanks to the fabulous people Jenny Gleisner, Helena Karresand, Dick Magnusson, Emmy Dahl, Alma Persson, Karin Skill, Ericka Johnson, Hannah Grankvist, Hanna Sjögren and Ann-Sofie Kall for all the fun talks, work talks and fikas! Malin Henriksson, it has been great approaching the finish line with you, including various distractions (no apps mentioned()). Anna Morvall, you were an excellent roomie to share space with! Aside from the production of texts many of us have also produced babies - and sharing stories about all these experiences has been excellent. Wenda Bauchspies, it's 
been a pleasure and very productive to work with you, and you've helped me stay STS'y! Thank you Lars Ingelstam for your support and good ideas! Eva Danielsson, Christina Lärkner and John Dickson, thank you for all your help! LiU-tryck did an excellent job with the cover, and thanks for your professional and quick work. I am also thankful to all my lovely former colleagues at the HR department for letting my hang on to my old workplace a bit. :) Baki Cakici, Francis Lee, Hanna Sjögren, Jenny Lee, Monica Brodén and Per Gyberg, thank you for helping me with proof-reading towards the end!

Thanks to my parents Monica and Peter Brodén for subconsciously brainwashing me into choosing this path by dragging my brother Victor and I with you on all kinds of challenging and extraordinary adventures in the world. Lots of hugs to my enormous extended family of which I am part - on both sides - for all your energizing awesomeness. Pelle, Saga, Rakel, Tyra and Dobby, thank you for sharing the joys and challenges of everyday life; like debating what to eat for dinner, pulling laundry around the house, making popcorn, solving logistical issues, deciding which action-adventurecomedy-fantasy-movie to watch, trips to Nicaragua and imagining futures. $\uparrow$

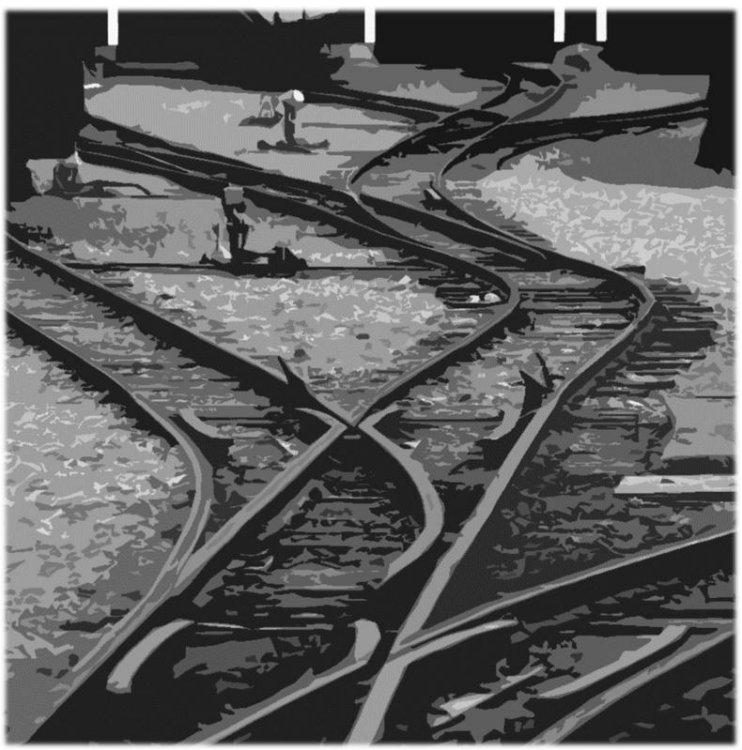




\section{Introduction and background}

Developing countries reliance on import of ready-made technology or research results will not suffice to satisfy basic needs. A pre-requisite for independent development strategies in this direction is a national capacity for research as well as for the development, evaluation and adaptation of technology. Massive resource transfers will only work if developing countries have absorption capacity. The lack of a minimum of national capacity in science and technology severely restricts the possibilities of developing countries to reach their economic and political goals. ${ }^{1}$

- Sarec Annual Report 1977/1978

...Development will increasingly depend on a country's ability to understand, interpret, select, adapt, use, transmit, diffuse, produce and commercialize scientific and technological knowledge in ways appropriate to its culture, aspirations and level of development. [...] Science and technology has always been important for development, but the unprecedented pace of advancement of scientific knowledge is rapidly creating new opportunities for and threats to development. ${ }^{2}$

- Strategic Approaches to Science and Technology in Development,

World Bank Report 2003

Science and technology have long been considered key for development in low-income countries, but knowledge resources in the world are unevenly distributed, and a disproportionate amount of the research conducted concerns issues and problems of relevance only to the richest countries in the world. ${ }^{3}$ The difference in "strength" between universities in high- and low-income countries is an area that more aid actors have come to focus on in the 1990's and 2000's. ${ }^{4}$ Foreign aid policies from recent decades are commonly studded with references to the knowledge society and the importance of science, technology and innovation for economic development as well as poverty reduction. This development accelerated when large actors such as the World Bank started underlining the importance of university education and research. ${ }^{5}$ The essence of what one could call this "knowledge-for-development" discourse within foreign aid is that increased knowledge will enable both growth and poverty reduction in low-income

\footnotetext{
${ }^{1}$ Sarec (1979). Sarec's Second Year, Annual Report 1977/1978. pp25-26

${ }^{2}$ Watson, R., M. Crawford, et al. (2003). Strategic Approaches to Science and Technology in Development. World Bank Policy Research Working Papers, The World Bank. abstract ${ }^{3}$ See for example Hollanders, H. and L. Soete (2010). The UNESCO Science Report 2010. The Current Status of Science Around the World UNESCO: Executive Summary. p6

4 Fisher, E. and D. Holland (2003). "Social development as knowledge building: research as a sphere of policy influence." Journal of International Development 15(7): 911-924. p912

${ }^{5}$ King, K. and S. McGrath (2004). Knowledge for Development? Comparing British, Japanese, Swedish and World Bank Aid. New York, Zed Books Ltd. p38. One of the reports said to have been most influential was the World Bank's Dahlman, C. and T. e. Vishwanath (1999). World Development Report 98/99: Knowledge for Development, The World Bank.
} 
countries, and that if they do not improve their knowledge systems they will lag even further behind.

Aid to universities as a solution to development problems is an interesting phenomenon to study since it straddles two contentious and in some ways very different political fields; foreign aid and research. The quotes above illustrate some of the many issues that this task entails. There are contradictions and tensions in research aid policy. The policies may, for instance, underline the importance of demand-driven and context sensitive development at the same time as they more or less explicitly uphold Western science as a universally applicable, objective and modern way to produce new knowledge (superior to other, more locally specific knowledge systems) - the one to be modeled. One could argue that this assumption implies that the form for development is already set, effectively contradicting the ambition of context sensitivity.

Which futures and paths are imagined, and by whom? The goals and methods of aid actors depend in part on what views of development they adhere to - explicitly or implicitly. In an analysis of the concept of progress, science and technology policy researcher Andy Stirling maintains that it is difficult to see a diversity of futures from the vantage point of a powerful actor (for example an aid actor): "Patterns of power in society may thus be seen not only as outcomes, but also as determinants of our understandings of progress. As a result, our imaginations of progress are, ironically, a principal factor conditioning the ways our progress actually unfolds." 6 Science and technology are strongly associated with progress and modernity, so questions concerning potential futures are highly relevant to consider as backdrop for this study. It is necessary to critically question how futures are described in aid policies because it is a partial reflection of how the aid actors work in low-income countries ${ }^{7}$ and therefore also - to some extent - the effects of aid.

The Swedish Agency for Research Cooperation with Developing Countries (Sarec) was a pioneer in this context; created in 1975 mainly to assist in improving research capacity in low-income countries. ${ }^{8}$ Sheila Jasanoff and San-Hyun Kim maintain that the relationship between science and technology and political institutions has remained "undertheorized" in the field Science and Technology Studies; "why states support science rarely gets asked." 9 This study asks that question, and uses the policy history of Sarec to illustrate how and why a non-scientific state actor promotes science

\footnotetext{
${ }^{6}$ Stirling, A. (2009). "Direction, Distribution and Diversity! Pluralising Progress in Innovation, Sustainability and Development." The STEPS Centre.p5

7 Instead of using the often misrepresentative categories of "developing" and "developed" countries, I will use low-income countries, middle-income countries, and high-income countries while recognizing that what constitutes development is a matter of definition and certainly not only tied to income. Low-income according to the World Bank is having an annual GNI per capita of $\$ 745$ or less. Middle-income countries: more than $\$ 745$, but less than $\$ 9,206$. High-income countries: $\$ 9,206$ or more.

${ }^{8}$ See for example Jones, N., M. Bailey, et al. (2007). Research capacity strengthening in Africa Trends, gaps and opportunities, Overseas Development Institute (ODI). p7

${ }_{9}^{9}$ Jasanoff, S. and S.-H. Kim (2009). "Containing the Atom: Sociotechnical Imaginaries and Nuclear Power in the United States and South Korea." Minerva 47(2): 119-146. p119-120
} 
and technology. Discourse theory, ${ }^{10}$ along with the concepts of sociotechnical imaginaries ${ }^{11}$ and boundary organization, ${ }^{12}$ are used to critically explore Sarec's research for development discourses.

This introductory chapter has two purposes - to present the object of study, the aim of the thesis and research questions, and to provide some background. The background in this case is a story about how the political fields of research and foreign aid develop and meet in both theory and practice.

Despite having ambitions of being as balanced and nuanced as possible, it is of relevance for researchers to somehow situate themselves in their work. The unequal distribution of resources globally is in my opinion problematic, I cannot look at this inequality entirely neutrally, and it is one of the main reasons why this topic is of interest to me. I have spent about 16 years of my life in Tanzania and Nicaragua with parents who worked in several different development organizations and aid agencies. Though I undoubtedly experienced these settings from a privileged standpoint, it nevertheless imprinted in me that what constitutes development differs depending on who you ask, where, and why.

\section{The object of study: Swedish research aid policy}

Sweden had one of the first national aid agencies ${ }^{13}$ to engage in research, Sarec was formed in 1975. Sweden had already supported research as a part of aid efforts on a smaller scale since the 1950's, but the formation of Sarec represented a shift in how the role of research in development was perceived. Its task was to work specifically to support development research and contribute to building research capacity in low-income countries. The organizational history of Sarec can be summarized as follows. Between 1975 and 1995 it was a free-standing public agency, after which it became a department within Sida. In 2008, Swedish aid politics changed significantly and Sida was reorganized. Sarec ceased to exist in the form that it had up until then, it changed names to the Secretariat for Research Cooperation and the majority of its staff was moved to other

\footnotetext{
10 Mainly inspired by Michel Foucault and Norman Fairclough

${ }^{11}$ Sociotechnical imaginaries can in short be described as specific normative views of how science and technology shape society, for example research projects or policies. This will be discussed in more detail in chapter two but my use of the concept is inspired by among others Sheila Jasanoff and Sang-Hyun Kim (2009).

12 As discussed by David Guston (2001)

13 The UN started working with development research soon after its inception in 1945, and the first national development agency to tackle the issue of research capacity was the International Development Research Centre (IDRC) in Canada 1970.
} 
parts of Sida. ${ }^{14} 15$ The timeline below outlines in a rough manner a small selection of the events of interest and relevance to the study.

\begin{tabular}{|c|c|c|c|c|c|c|}
\hline 1960 & & & & & & 2010 \\
\hline $\begin{array}{l}\text { Sarec/ } \\
\text { Sida-Sarec }\end{array}$ & $\begin{array}{l}\text { Forskning för } \\
\text { utveckling } \\
\text { SOU 1973:41 }\end{array}$ & $\begin{array}{c}\text { Sarec was } \\
\text { formed } 1975\end{array}$ & $\begin{array}{c}\text { Sarec } \\
\text { independent } \\
\text { agency } 1979 \\
10 \text { year } \\
\text { evaluation } \\
1985\end{array}$ & $\begin{array}{c}20 \text { year review } \\
1995 \\
\text { Sarec merged } \\
\text { with Sida } 1995\end{array}$ & $\begin{array}{c}30 \text { year } \\
\text { evaluation } \\
2006\end{array}$ & $\begin{array}{l}\text { Sarec disbands } \\
2008 \\
\text { New strategy } \\
\text { for research } \\
\text { aid 2010-2014 }\end{array}$ \\
\hline Foreign aid & $\begin{array}{c}\text { Sida was } \\
\text { formed } 1965\end{array}$ & & $\begin{array}{c}\text { The } \\
\text { environment } \\
\text { was included } \\
\text { in a new } \\
\text { Swedish aid } \\
\text { goal } 1988\end{array}$ & $\begin{array}{l}\text { Sweden joined } \\
\text { the EU } 1995\end{array}$ & $\begin{array}{c}\text { Policy for } \\
\text { global } \\
\text { development } \\
2003\end{array}$ & $\begin{array}{l}\text { Foreign aid } \\
\text { politics and } \\
\text { Sida } \\
\text { reorganized } \\
2008\end{array}$ \\
\hline Research & & $\begin{array}{c}\text { First Swedish } \\
\text { Research Bill } \\
1981\end{array}$ & $\begin{array}{l}\text { Research bill: } \\
\text { Research for } \\
\text { knowledge } \\
\text { and progress } \\
1992\end{array}$ & $\begin{array}{l}\text { Research bill: } \\
\text { Research and } \\
\text { society } 1996 \\
\text { Research bill: } \\
\text { Research and } \\
\text { Renewal } 2000\end{array}$ & $\begin{array}{l}\text { Research bill: } \\
\text { Research for a } \\
\text { better life } \\
2004\end{array}$ & $\begin{array}{l}\text { Research bill: } \\
\text { Research and } \\
\text { Innovation } \\
2008\end{array}$ \\
\hline $\begin{array}{l}\text { Inter- } \\
\text { national } \\
\text { aid and } \\
\text { research } \\
\text { events }\end{array}$ & $\begin{array}{c}\text { UNCSAT } \\
\text { conference } \\
\text { Geneva } 1963\end{array}$ & $\begin{array}{l}\text { UN world plan } \\
\text { of action } \\
\text { S\&T4D } 1971\end{array}$ & $\begin{array}{c}\text { UNCSTD } \\
\text { conference } \\
1979\end{array}$ & $\begin{array}{l}\text { World Bank } \\
\text { Report on } \\
\text { Knowledge for } \\
\text { development } \\
1998\end{array}$ & $\begin{array}{l}\text { Millennium } \\
\text { development } \\
\text { goals } 2000\end{array}$ & $\begin{array}{l}\text { Paris Agenda } \\
\text { on aid } \\
\text { effectiveness } \\
2005\end{array}$ \\
\hline
\end{tabular}

\section{Table 1: Timeline}

Sarec's activities have been based on the conviction that research can be an important tool for poverty reduction and on the belief that national research capacity ${ }^{16}$ is necessary

\footnotetext{
${ }^{14}$ Another reorganization occurred in 2011. By then, the staff working with research had been reduced by $50 \%$. Staff are now divided between a secretariat (research unit), the long-term program department (PROGSAM) and Swedish Embassies. Essentially the task remains the same, the budget remains around one billion crowns but the responsibilities for implementation are more spread out.

15 The total budget for Swedish aid has increased over time, although it has fluctuated up and down quite a bit throughout the decades. In 1975 the budget was 2.35 billion Crowns and in 2012 it was 37.8 billion Crowns. The greatest and most consistent increases have occurred between 2000 and now, according to Openaid.se. (2013). "Sveriges totala bistånd." Retrieved 102213, from www.openaid.se.. The budget for research (most of which has been channelled through Sarec and/or Sida) was 75 million crowns in the beginning and in 2012 it was around one billion crowns.

16 The definition of research capacity includes everything from individual researcher's skills to information and communication technologies, laboratories, and national research policies.
} 
in order for low-income countries to be able to tackle their own development problems. Sarec has aided research through three major programmes which in turn include several different forms of cooperation or support that will be explained later on. The bilateral programme (involving cooperation between universities in Sweden and universities in low-income countries) has been considered the main way through which to contribute to capacity building, while the other two areas (support to Swedish development research and to international research organizations) have been classified as thematic given that their main aim has been to support development relevant research. Though the two overlap in terms of effects, bilateral support is more focused on strengthening the preconditions for research whereas the thematic support is results-oriented. The organizational development of Sarec will be discussed in more detail in the empirical chapters, but the fact that it was one of the pioneer organizations of its kind makes it an interesting object of study. Sarec produced annual reports, evaluations and a number of other documents through which it is possible to follow quite consistently how their policies developed.

The "place" of research aid in Swedish politics is the middle of two political policy spheres - research and foreign aid - the former belonging to the ministry of education and research and the latter to the ministry of foreign affairs - making Sarec a boundary organization in this sense. ${ }^{17}$ The overarching goal of Swedish foreign aid is to contribute to poverty reduction in low-income countries while the goals of research somewhat simplified - are to produce new knowledge and contribute to national development. ${ }^{18}$ Internationalization is a priority in research policy, but cooperation is encouraged with middle and high-income countries first and foremost. ${ }^{19}$ The goal of Swedish research aid is to support development-relevant research and contribute to building research capacity in low-income countries, and the research agendas pursued are to be based on low-income country priorities. While research seems relatively wellrecognized as a tool in foreign aid policy, ${ }^{20}$ development-relevance seems to be

\footnotetext{
${ }^{17}$ A boundary organization being one that has to perform a task involving at least two distinct political areas, as discussed in Guston, D. (1999). "Stabilizing the Boundary between US Politics and Science: The Role of the Office of Technology Transfer as a Boundary Organization." Social Studies of Science 29(1): 87-111

${ }^{18}$ See for example the discussion about growth and increased commercialization of research in (2008). Ett lyft för forskning och innovation. Regeringens proposition 2008/09:50. T. S.

Government. pp1-2. This is also an interesting issue since the institutional setting for research is national, yet research itself has numerous international components and the results do not necessarily benefit the country in which the research is "housed." See for example Edqvist, 0. (2009). Gränslös forskning, Nya Doxa. and Benner, M. (2008). Kunskapsnation i kris. Politik, pengar och makt i svensk forskning, Nya Doxa.

${ }^{19}$ This seems to be the case in Canada as well, for example; cooperation with middle and highincome countries is encouraged but commitments above and beyond standard internationalization measures need to be made in order to increase cooperation with lowincome countries. See Angeles, L. and P. Boothroyd (2003). "Canadian Universities and International Development: Learning from Experience." Canadian Journal of Development Studies 24(1): 9-26.

${ }^{20}$ Even though some evaluations show that there might be differences in opinion regarding exactly how this "tool" should be used.
} 
considered more like a desirable side effect in research bills. ${ }^{21}$ The two policy areas are not always compatible; goals are quite different, and results are measured differently in the two fields. The fact that research cooperation with low-income countries is a relatively marginalized issue in research politics places the research aid actor in a challenging position. ${ }^{22}$ This is another of the reasons why research aid policy is an interesting study object.

\section{Purpose, research questions and delimitations}

This study investigates how Swedish official aid policy constructs the role of research for development in low-income countries. The policies include sociotechnical imaginaries which support and enable certain types of development and not others. I have chosen to study these through an analysis of the evolution of Sarec's policies between 1973 and 2008. While support to development-related research activities also involved other Swedish state actors and organizations during different periods, focusing on the case of Sarec is warranted since it was by far the most central actor.

The overarching purpose of the study is to contribute to an understanding of how research policy discourse in the context of foreign aid has developed and changed during the last few decades. The main research questions are listed below.

1. How is the role of research for development constructed? How are individual researchers and universities seen to contribute to development? How is the role of the aid actor portrayed?

2. What discourses can be identified in the policy development and how do these relate to each other over time; what kind of futures are imagined?

3. What can the Sarec case say about the relationship between science policy and aid policy in the post WWII period?

The study ends 2008 given the fact that Sarec is radically reorganized that year along with the rest of Sida, but I comment briefly on the developments post-2008 in the epilogue. The empirical materials and methods used to explore these questions are discussed in further details in chapter three but I use annual reports, methods documents, evaluations, government bills and investigations, and parliamentary records. They are all official

\footnotetext{
${ }^{21}$ In the research bill from 2012 no significant changes can be noted in this area, research partnerships with middle-income/BRIC countries are still encouraged on a strategic basis. ${ }^{21}$ Low-income countries are largely absent, except for a section of the bill where it is established that the Swedish Research Council (Vetenskapsrådet) takes over the responsibility for distributing the funds for Swedish development research and that applications will be judged primarily by scientific relevance.

22 Despite the PGU and references to cooperation with low-income countries in research-related government bills and increased attention to internationalization, Sarec's research council remains the heaviest funder of development research. See also Edqvist, O. (2009). Gränslös forskning, Nya Doxa.
} 
policy documents. I have also conducted interviews with former directors and other key informants.

My main aim is not to evaluate the development of research aid discourse per se, but rather to explore and analyze it from different perspectives. This ambition is in line with the view of sociologist and development theorist Jan Nederveen Pieterse, who maintains that discourse analysis lends itself well to critical analysis, not policy formulation. It is most appropriate for "critiquing hegemonic discourses and exposing its silences, omissions and double talk", including "the scrutiny of development policy, official texts and development thinking." 23 Nederveen Pieterse also maintains that combining discourse analysis with contextual information (about political economy for instance) makes the critique more useful, something which I have also attempted to do. In line with this reasoning, I will not be making concrete recommendations, but the study can nonetheless constitute useful background for discussions about past, current and future policy. ${ }^{24}$

This study is first and foremost situated within the field of Science and Technology Studies (STS) but it also draws on different parts of Development Studies. These fields are in turn influenced by several disciplines like economics, history, sociology and political science, to name a few. The study can be of interest in different ways to these fields - empirically, theoretically or methodologically.

\section{Outline of the book}

Chapters one to four comprise introduction, background, theoretical perspectives, previous research and methods and materials. Chapters five to eight are the main empirical chapters, beginning with an analysis of the founding, early documents from the 1970s. Chapters six to eight focus roughly on the 1980s, 1990s and 2000s respectively. The empirical chapters include both contextual information of relevance for the decade in question as well as analysis of policy development and interviews with directors. Chapter nine is a concluding discussion followed by a short epilogue which includes reflections on the development in the years after 2008.

Empirical chapter
\begin{tabular}{|l|l|}
\hline 5. Tracing the foundations & $\begin{array}{l}\text { Period and key material } \\
\text { Sarec's first annual reports, interview with Björn } \\
\text { Hettne, Economic Debate articles. It starts with the } \\
\text { founding state investigation and ends with Sarec } \\
\text { becoming an independent agency. }\end{array}$ \\
\hline & \\
\hline
\end{tabular}

\footnotetext{
${ }^{23}$ Nederveen-Pieterse, J. (2011). "Discourse analysis in international development studies." Journal of Multicultural Discourses 6(3): 237-240. pP239

${ }^{24}$ See also for example Nowotny, H. (2004). Does History of Science Have Policy Implications? The Science Industry Nexus. History, Policy, Implications. K. Grandin, N. Wormbs and S. Widmalm, Science History Publications/USA \& The Nobel Foundation.
} 


\begin{tabular}{|c|c|}
\hline 6. Settling in and becoming pragmatic & $\begin{array}{l}\text { 1980-1989. The } 10 \text {-year evaluation, annual reports, } \\
\text { interviews with Lars Anell and Bo Bengtsson. It starts } \\
\text { with Sarec's first independent year and is rounded off } \\
\text { as the cold war ended. }\end{array}$ \\
\hline 7. Revival and change & $\begin{array}{l}\text { 1990-1997. Methods document, the } 20 \text {-year review, } \\
\text { annual reports, interviews with Bo Bengtsson, Anders } \\
\text { Wijkman, Johan Holmberg and Rolf Carlman. The } \\
\text { beginning of the decade is characterized by the start of } \\
\text { new global aid politics, and ends the year before Sida- } \\
\text { Sarec publishes a new kind of methods documents. }\end{array}$ \\
\hline $\begin{array}{l}\text { 8. Constructing sustainable } \\
\text { knowledge societies }\end{array}$ & $\begin{array}{l}\text { 1998-2008. Methods documents, annual reports, the } \\
\text { 30-year evaluation, interviews with Rolf Carlman and } \\
\text { Berit Olsson. It starts with the publication of new } \\
\text { methods documents and ends with the disbanding of } \\
\text { Sarec. }\end{array}$ \\
\hline
\end{tabular}

\section{Background - aiding scientific research}

A brief account of the development and general trends within research and foreign aid internationally and in Sweden provides a useful background against which to understand Sarec. Here it is appropriate to point out that the empirical material that I have analyzed sometimes includes quite explicit reflections about theory concerning for example development and research or knowledge production. These reflections and references mirror political trends and schools of thought in academia during the decades in question (both dominant and challenging trends). This is why I discuss them in this section as background rather than under theoretical perspectives or previous research. It is a way to contextualize the empirical material and inform my discourse analysis.

Scientific research is considered a central driving force in the modern world and universities are therefore seen as important actors. ${ }^{25}$ Apart from providing higher education and conducting research, universities are also expected to more directly stimulate national economic growth and development through cooperating with other public and private actors. Developmental universities is one of the concepts that reflect these demands, entrepreneurial universities is another. ${ }^{26}$ There are, however, different opinions regarding how universities affect a country's social and economic

25 See for example Shapin, S. (2008). Science and the Modern World Handbook of Science and Technology Studies (3rd ed). E. J. H. e. a. (eds), The MIT Press.p433

26 See for example Brundenius, C., B.-A. Lundvall, et al. (2009). The role of universities in innovation systems in developing countries: Developmental University Systems - Empirical, Analytical and Normative Perspectives. Handbook of Innovation Systems and Developing Countries - Building Domestic Capabilities in a Global Setting. B.-Å. Lundvall, K. J. Joseph and C. e. Chaminade, Edward Elgar Publishing. It should be noted that Developmental universities is not an entirely new concept, see for example Coleman, J. S. (1986). "The idea of the developmental university." Minerva 24(4): 476-494. 
development, ${ }^{27}$ and there are studies which suggest that universities often lack the capacity to live up to all of these demands. ${ }^{28}$ Discussions about development - including universities - often seem to be framed more or less explicitly by gap questions; "what is missing (in x country or organization for instance)?" in comparison with high-income countries. When discussing the distribution of research capacity in the world for example, one UN report concludes the following:

...the knowledge divide is deep and is heavily tilted in favor of developed countries. Developing countries suffer from a lack of both financial and human resources in R\&D. They need to improve their capacity to produce knowledge domestically and absorb the knowledge produced elsewhere. This can happen when allocation of financial resources to R\&D activities increases, human resources are trained in adequate numbers and an institutional framework to carry out R\&D activities is created. ...There is a need for reviving and strengthening the university system in developing countries to strengthen their research capacities. ${ }^{29}$

The questions appear in different shapes and forms - but they concern gaps that need to be filled in order to promote progress of some kind. Similar questions are also asked in high income countries, the difference being that they are often perceived as already being at the top of the development ladder - or at least further ahead in the "race" when compared to low-income countries. One might ask whether it is ever possible for lowincome countries to ever "catch up" as long as the premises are that gaps need to be filled in relation to specific stages of development. Either way, improving research capacities is envisioned as one way of enabling this catch-up, as exemplified on Sida's website:

By helping developing countries build up their own research capabilities, Sida indirectly enhances their ability to negotiate, choose technologies, make use of natural resources and develop the social sector. It puts them on a more equal footing with the developed world. ${ }^{30}$

The terminology developed versus developing remains, as illustrated by this quote, yet the divisions in the world are of course considerably more complex. Countries can also be classified as being low, middle and high-income - and inequalities are many times larger within countries than between countries. While this complexity is also acknowledged in other parts of this and other aid policy, simplifications are common.

27 See for example Mowery, D. C. and B. N. Sampat (2005). Universities in National Innovation Systems The Oxford handbook of innovation. J. Fagerberg, D. C. Mowery and R. R. e. Nelson, Oxford University Press.

${ }^{28}$ See for example Göransson, B., R. Maharajh, et al. (2009). "Introduction: New challenges for universities beyond education and research." Science and Public Policy 36(2): 83-84. p83

${ }^{29}$ Sanyal, B. C. and N. V. Varghese (2007). Research Capacity of the Higher Education Sector in Developing Countries, International Institue for Educational Planning, UNESCO. p2

${ }^{30}$ Sida. "From funding research to fighting poverty." Retrieved October, 2010, from http://www.sida.se/English/Partners/Universities-and-research/From-funding-research-tofighting-poverty/. 
The idea that research is important for development seems relatively unquestioned by aid actors though there is discussion about which challenges that are the most pressing and what methods are adequate to address them. To give an international aid actor example, the UN Educational, Scientific and Cultural Organization (UNESCO) maintains that while internationalization of research and higher education has many positive effects, national government funds seldom suffice and industry has thus become a more significant financial actor, resulting in a trend of "academic capitalization" where knowledge is treated more and more as a commodity. ${ }^{31}$ According to UNESCO, this trend jeopardizes the public good of research. ${ }^{32}$ Similar concerns are voiced by other aid actors and are also frequently discussed in the academic literature. ${ }^{33}$

\section{Changes in research}

The world of higher education and research has gone through many changes in the last century, not least in the period after World War II. The number of universities has grown, and the number of students enrolled in higher education in low-income countries more than doubled between 1980 and 1995. ${ }^{34}$ The end of the 20 $0^{\text {th }}$ century saw a considerable acceleration in the internationalization of education and research. ${ }^{35}$ Different explanations for this include the end of the Cold War, the spread of new information and communication technologies (ICT's), and economic globalization. ${ }^{36}$ Putting aside the potential explanations as to the whys, the amount of spending on education, research and development (R\&D) worldwide has increased greatly. UNESCO statistics, for example, show that global investment in R\&D (including the business sector) increased by $44 \%$ between 2002 and 2007.37

As discussed above, however, resources are unequally distributed across the world. ${ }^{38}$ of the resources spent on research, around $85 \%$ are invested in high-income

\footnotetext{
31 UNESCO. "Higher Education Section "Some general trends and Challenges" " Retrieved February, 2011, from http://portal.unesco.org/education/en/ev.php-

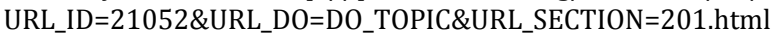
32 Ibid.

${ }^{33}$ For example Altbach, P., G. (2007). "Peripheries and Centres: Research Universities in Developing Countries." Higher Education Management and Policy 19(2): 106-130. And Altbach, P., G. and J. Knight (2007). "The Internationalization of Higher Education: Motivations and Realities." Journal of Studies in International Education 11(3-4): 290-305

34 (2000). Higher Education in Developing Countries - Perils and Promise. The Taskforce on Higher Education and Society. T. W. Bank. p27

35 See for example Frank, D. J. and J. W. Meyer (2007). "University expansion and the knowledge society." Theory and Society 36(4): 287-311. ${ }^{36}$ See for example King, K. and S. McGrath (2004). Knowledge for Development? Comparing British, Japanese, Swedish and World Bank Aid. New York, Zed Books Ltd. p22-30 37 UNESCO (2009). A Global Perspective on Research and Development (2009). UIS Fact Sheet No. 2-09. U. I. f. Statistics. and UNESCO (2004). A Decade of Investment in Research and Development (R\&D): 1990-2000 UIS Bulletin on Science and Technology Statistics Issue No. 104. U. I. f. Statistics.

38 Weiler, H. N., S. Guri-Rosenblit, et al. (2006). Universities as Centres of Research and Knowledge Creation: An Endangered Species? Summary report from Colloquium on Research and Higher Education UNESCO. p1
} 
countries, $10 \%$ in middle-income countries like India, China, and Brazil. Between 4 and $5 \%$ of the resources are invested in low-income countries - most of which is through highincome country actors undertaking research there. ${ }^{39}$ An estimated 5 to $10 \%$ of all research funding concerning global health goes to research on problems that affect $90 \%$ of the world's population, and only a fraction of this funding actually goes to researchers in low-income countries. ${ }^{40}$ In other words, there is a large gap between high and lowincome countries both in terms of access to resources for research and in terms of who is benefited by the results.

International scientific collaboration is also growing significantly, but the benefits for low-income countries remain relatively small in terms of for example the amount of scientific paper publications. According to studies from 2003 and 2009, only $30 \%$ of the publications based on research carried out in low-income countries include an author from those countries, ${ }^{41}$ and roughly $80 \%$ of research papers produced in Central Africa are co-written with researchers from outside the region. ${ }^{42}$ The unequal distribution of resources for research can be illustrated by the map below.

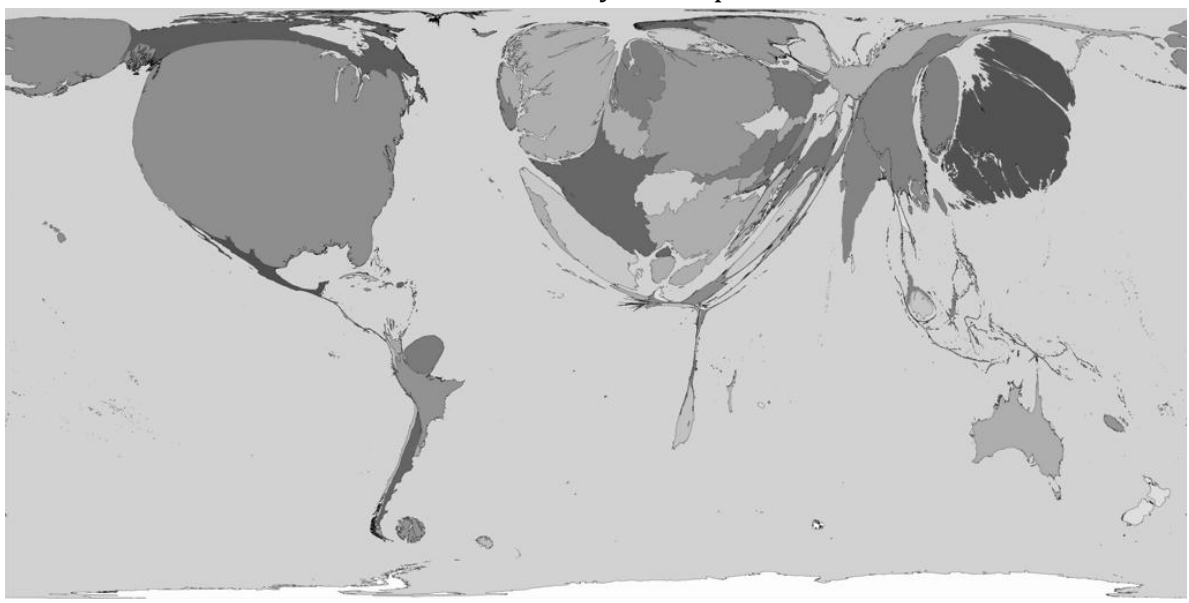

Figure 1: Scientific papers published $2001^{43}$

${ }^{39}$ Young, J. and N. Kannemeyer (2001). Building Capacity in Southern Research: A Study To Map Existing Initiatives. O. D. I. (ODI). p2

${ }^{40}$ (1999). The 10/90 Report on Health Research. G. F. f. H. Research. Geneva.

${ }^{41}$ Dahdouh Guebas, F., J. Ahimbisibwe, et al. (2003). "Neo-colonial science by the most industrialised upon the least developed countries in peer-reviewed publishing " Scientometrics 56(3): 329-343. p329

${ }^{42}$ Boshoff, N. (2009). "Neo-colonialism and research collaboration in Central Africa." Ibid. 81(2): 413-434. p413

43 (C) Worldmapper. "Map 205, "Science Research"." Retrieved August, 2010, from www.sasi.group.shef.ac.uk/worldmapper/. "Territory size shows the proportion of all scientific papers published in 2001 written by authors living there. There is more scientific research, or publication of results, in richer territories. This locational bias is such that roughly three times more scientific papers per person living there are published in Western Europe, North America, and Japan, than in any other region." 
The territory sizes illustrate the proportion of scientific papers published per million people and is based on statistics from 2001.44 A similar map shows the growth of published articles between 1990 and 2001, during which period the number of scientific papers published per million people in the world went from 80 to 106.45 The increase was primarily found where the existing scientific research was already relatively strong, and the strongest increase occurred in China, Japan, Germany, the Republic of Korea, and Singapore. The territory with least amount of published articles in 2001 per million people was Central Africa, and the highest amount was in Western Europe. ${ }^{46}$ Comparing the amount of published papers per region is of course just one way of measuring scientific activity. Between 2002 and 2007 for example, the number of researchers in lowincome countries went from 1.8 to 2.6 million (a $45 \%$ increase) compared to an $8.6 \%$ increase of researchers in high-income countries. ${ }^{47}$ On average, $29 \%$ of the researchers in the world are women.

These statistics indicate that though the global distribution of resources for research is still highly unequal, there may be some positive trends under way for a number of low-income countries. ${ }^{48}$ Heavy teaching loads, low salary levels, and brain drain are examples of challenges facing researchers in low-income countries. ${ }^{49}$

\section{Theories about science (technology) and policy}

I will go through some of the theories and perspectives that have influenced attempts to manage scientific knowledge in the post-WWII period. The linear model of innovation was one of the first developed frameworks for analyzing how science and technology related to the economy. The general idea was that innovation occurs through a linear process beginning with basic research, followed by applied research and development, to then end with production and diffusion. The linear model has been criticized and declared dead countless times in the last fifty years. ${ }^{50}$

\footnotetext{
${ }^{44}$ It is based on statistics on scientific work within the fields of physics, biology, chemistry, mathematics, clinical medicine, biomedical research, engineering, technology, and earth and space sciences. It does not provide a complete picture since it excludes social sciences and humanities, and it does not take other forms of scientific activity or other ways of publishing research, but it provides an interesting illustration nonetheless.

${ }^{45}$ Worldmapper. "Map 206, "Science Growth", accessed in August 2010." Retrieved August, 2010, from www.sasi.group.shef.ac.uk/worldmapper/.

${ }^{46}$ See for example Wagner, C. S. and L. Leydesdorff (2005). "Network structure, self-

organization, and the growth of international collaboration in science." Research Policy 34(10): 1608-1618.

47 UNESCO (2009). A Global Perspective on Research and Development (2009). UIS Fact Sheet No. 2-09. U. I. f. Statistics.

${ }^{48}$ See for example UNESCO (2005). What do Bibliometric Indicators tell us about World Scientific Output? . UIS Issue No. 2-05. U. I. o. Statistics.

${ }^{49}$ See for example Sawyerr, A. (2004). "African Universities and the Challenge of Research

Capacity Development1." Journal of Higher Education in Africa 2 (1): 213-242.

50 Godin, B. (2005). "The Linear Model of Innovation: The Historical Construction of an Analytical Framework." Science Technology Human Values 31(6): pp659-660.
} 
Alternatives to the linear model are often characterized as more systemic in the sense that they include more actors and processes and account for links between them in a more flexible way. Etzkowitz and Leydersdorff summarize three such models that have been proposed to explain how science and technology relate to the economy: the model national systems of innovation (NSI) ${ }^{51}$, the model of an emerging "Mode 2 " of the production of scientific knowledge ${ }^{52}$, and the model of a Triple Helix of universityindustry-government relations".53 54 The three models/theories have important differences concerning for example focus/purpose, analytical use, and scope. They also identify and prioritize actors and their interrelations differently, but they take as a point of departure the idea that knowledge production and innovation follows a non-linear dynamic and requires collaboration between many actors in a system. Universities and scientific research are seen as essential, but collaboration between actors in a system (mainly academia, industry and government but also other actors like civil society groups and NGO's) is seen to increase a country's or region's innovative abilities.

Similar arguments are made by science policy researcher John Ziman, who distinguishes between academic science and postacademic science (Mode 2 is a form of postacademic science) where the latter, guided by more entrepreneurial norms, is expected to "shed some of the doctrines of 'modernism'". In particular, it will not claim to be able to produce a universally applicable answer to every problem. ${ }^{55}$ Ziman envisioned Robert K. Mertson's traditional CUDOS norms (communalism, universalism, disinteredness, originality and skepticism) as being replaced by PLACE (property, local, authoritarian, commissioned and expert). ${ }^{56}$

Modes 1 and 2 are portrayed as two different modes of knowledge production (one old and one new). ${ }^{57}$ Mode 1 science, according to a review by science policy researcher Fredrik Melander, tends to be disciplinary in orientation, more oriented towards basic sciences and relatively homogenous in its organizational structures. Research problems are usually formulated in the academic context. Mode 2, in contrast, is characterized by transdisciplinarity, applicability and usefulness. Research problems are defined within the context that they are relevant to, and there is great diversity when it

\footnotetext{
${ }^{51}$ Se for example Freeman 1987, Lundvall 1988 and 1992, Nelson 1993, Edquist 1997

52 Gibbons, M., C. Limoges, et al. (1994). The New Production of Knowledge - The Dynamics of Science and Research in Contemporary Societies, SAGE Publications.

${ }^{53}$ Etzkowitz, H. and L. Leydesdorff (2000). A Triple Helix of University-Industry-Government Relations: »Mode 2 « and the Globalization of »National« Systems of Innovation, in "Science under pressure" The Danish Institute for Studies in Research and Research Policy p8 54 Etzkowitz and Leydersdorff $(1995,1997$, and 2000)

55 Ziman, J. (1996). "Post-academic Science': Constructing Knowledge with Networks and Norms." Science Studies 9(1): 67-80. p77

56 Melander, F. (2006). Lokal forskningspolitik. Institutionell dynamik och organisatorisk omvandling vid Lunds universitet 1980-2005, Lund University. pp91-93

${ }^{57}$ Shinn, T. (2002). "The Triple Helix and New Production of Knowledge: Prepackaged, Thinking on Science and Technology." Social Studies of Science 32(4): 599-614. p600
} 
comes to the organizational structures that support the research (universities are just one such place, industry, think tanks and different kinds of research centres are others). ${ }^{58}$

Science policy researcher Terry Shinn compares and discusses Mode 1/Mode $2^{59}$ and Triple Helix. In mode 1, he maintains, the links between academia and society (including industry) are said to be few, and the university is relatively free and selfdefined. In mode 2 (which is said to have gained in strength since the end of World War II) the modern university is collapsing in a sense. Peer control over research priorities is eroded, and disciplines are increasingly replaced by problem-oriented, interdisciplinary science in short-term taskforce expert teams. ${ }^{60}$ Shinn states that in contrast to this, Triple Helix claims historical continuity; that relations between university, industry, and government have always existed and continue to do so. What has been added is a layer of "knowledge development" - in which groups from all three sectors collaborate on certain problems that arise. ${ }^{61}$ Shinn is critical of the claims of both views and maintains that both fail to account for the fact that universities are still situated in national contexts for example, and he maintains that both tendencies co-exist.

Similar criticism is delivered by Godin in a review of The New Production of Knowledge - where he maintains that Mode 1 never really existed in pure form and Mode 2 is not exactly taking over either. ${ }^{62}$ STS researchers Philip Mirowski and Esther-Mirjam Sent agree, and maintain that the stage 1/stage 2 narrative is superficial and does not mirror the history of science particularly well. Universities have always "served society" in many ways and academic freedom has never been as free as it is sometimes claimed. ${ }^{63}$

The models above in part react against the linear model, but technology historian David Edgerton maintains that the linear model has never really been used as a model. He opposes attempts to give the model more "historical agency" than it deserves. ${ }^{64}$ He claims that Science - the Endless Frontier65, a text often cited as the birthplace of the

\footnotetext{
${ }^{58}$ Melander, F. (2006). Lokal forskningspolitik. Institutionell dynamik och organisatorisk omvandling vid Lunds universitet 1980-2005, Lund University. pp98-99

${ }^{59}$ The discussion about mode 1 and mode 2 started in 1994 in Gibbons, M., C. Limoges, et al. (1994). The New Production of Knowledge - The Dynamics of Science and Research in Contemporary Societies, SAGE Publications. and continued in the book Nowotny, H., P. Scott, et al. (2001). Re-thinking science: knowledge in an age of uncertainty, Polity Press.

${ }^{60}$ Shinn, T. (2002). "The Triple Helix and New Production of Knowledge: Prepackaged, Thinking on Science and Technology." Social Studies of Science 32(4): 599-614.

61 Ibid.

62 Godin, B. (1998). "Writing Performative History: The New New Atlantis? ." Ibid. 28(3): 465483.

${ }^{63}$ Mirowski, P. and E.-M. Sent (2008). The Commercialization of Science and the Response of STS. The Handbook of Science and Technology Studies (3rd ed). E. J. Hackett, O. Amsterdamska, M. Lynch and J. Wajcman, the MIT Press: 636-637.

${ }^{64}$ Edgerton, D. (2004). The "Linear Model" Did not Exist. Reflections on the History and Historiography of Science and Research in Industry in the Twentieth Century The ScienceIndustry Nexus. History, Policy, Implications. K. Grandin, N. Wormbs and S. Widmalm, Science History Publications/USA \& The Nobel Foundation.p34

${ }^{65}$ A 1945 report by Vannevar Bush, then Director of Scientific Research and Development
} 
linear model, has been misinterpreted, and in fact does not propose a linear model. ${ }^{66}$ In the same book, David Hounsell and other authors argue that however misinterpreted the Bush document may have been, the model has nevertheless affected science policy significantly. ${ }^{67}$

None of the researchers referred to above seem to deny that there are significant changes going on in the relationship between science and the rest of society, but are pointing out that they are often discussed in a simplified manner. The alternative terms and models (such as the ones discussed above) to discuss the "new" situation are equally reductionist and simplifying in that they focus on such a small part of the sciencesociety landscape, according to science policy researcher Aant Elzinga. ${ }^{68}$ In a similar line of argument, STS researcher Andrew Jamison talks about how the role of technology is also simplified within the innovation-oriented discussions:

the story-line of innovation has come to provide the dominant way in which technology is discussed. [...] The ways in which these stories are told follows a typical pattern, which can be characterized as a form of technological determinism, according to which new, radical innovations - in our day, primarily in information technologies, genetic engineering, and nanotechnology - are claimed to be the central factors behind economic growth and "competitiveness." 69

As mentioned above, the idea of innovation systems started out as an alternative way to account for the role of technology in economic growth. Jamison maintains that the focus on innovation to a large degree has come to focus on certain sciences and technologies, and that it is a kind of technological determinism. In relation to research and research aid, it becomes significant not least because it might entail that technological sciences are prioritized at the expense of social sciences and the humanities for example. This is a problem if one assumes that scientific diversity is important.

This study deals with technology in a relatively indirect manner, but it is nonetheless of importance to explore some of its conceptualizations in relation to science. According to STS-researcher Sergio Sismondo, technology is often conceived of as applied science (in the kind of linear line of argumentation discussed above). STS research, however, suggests that reality is more pragmatic: "Scientists" invent, and "inventors" do

\footnotetext{
${ }^{66}$ Edgerton, D. (2004). The "Linear Model" Did not Exist. Reflections on the History and Historiography of Science and Research in Industry in the Twentieth Century The ScienceIndustry Nexus. History, Policy, Implications. K. Grandin, N. Wormbs and S. Widmalm, Science History Publications/USA \& The Nobel Foundation. p40

${ }^{67}$ Hounsell, D. A. Ibid.Industry Research. K. Grandin, N. Wormbs and S. e. Widmalm. pp63-64

${ }^{68}$ Elzinga, A. Ibid.The New Production of Reductionism in Models Relating to Research Policy. K. Grandin, N. Wormbs and S. Widmalm. pp278-279. See also Elzinga, A. (2004). "Metaphors, models and reification in science and technology policy discourse." Science as Culture 13(1): 105-121., (a review of the book Miettinen, R. (2002). National Innovation System. Scientific concept or political rhetoric?, Edita.

${ }^{69}$ Jamison, A., S. Hyldgaard Christensen, et al. (2011). A Hybrid Imagination. Science and Technology in Cultural Perspective, Morgan \& Claypool. p19
} 
scientific research - whatever is necessary to move their program forward". ${ }^{70}$ Both science and technology are situated and complex, they are constantly under negotiation and construction: "the interpretations of knowledge and artifacts are complex and various: claims, theories, facts, and objects may have very different meanings to different audiences." 71 Sismondo maintains that scientific knowledge is one of many different kinds of knowledge required in the development of technology, just like technology is often used in the process of producing scientific knowledge. ${ }^{72}$

In relation to research and knowledge production, it is of relevance to consider how the role of technology is conceived. Depending on how central technology itself is considered, social factors and contexts are ascribed different amounts of significance. For example, sometimes new information and communication technologies and the internet are rather uncritically described as changing the world - social and other contextual factors like demand, levels of education or existing infrastructure are not acknowledged as particularly important co-drivers. With this view, it would be logical to transfer technologies and more or less expect them to function as "intended" in its original context. Genetically modified organisms (GMO), industrial machinery, XO laptops ${ }^{73}$ or ehealth software may be upheld as drivers of economic growth and/or increases in social welfare:

There are a number of technological determinisms (See Bimber 1994; Wyatt 2007), but the central idea is that technological changes force social adaptations, and consequently constrain the trajectories of history. [...] Because economic actors make rational choices, class structure is determined by the dominant technologies. This reasoning applies to both the largest scales and much more local decisions. Technology, then, shapes economic choices, and through them shapes history. ${ }^{74}$

Experiences regarding these examples have shown that it is not that simple, but one can still find quite technologically deterministic and optimistic projections in development policies for example. There is a scale from soft to hard technological determinism where different weight is accorded to the factors surrounding the technology, affecting its preconditions and potential developments and effects.

Awareness and opinion concerning the risks and potentially negative effects of science and technology has grown. Efforts by governments, industry, and other organizations (including aid actors) to manage, regulate, and steer knowledge have grown, illustrated by for example the proliferation of science and technology policies,

\footnotetext{
${ }^{70}$ Sismondo, S. (2010). An Introduction to Science and Technology Studies (2nd ed), WileyBlackwell. p95

${ }^{71}$ Ibid. p11

72 Ibid. p96

73 The One laptop per child project http://laptop.org/en/laptop/

${ }^{74}$ Sismondo, S. (2010). An Introduction to Science and Technology Studies (2nd ed), Wiley-

Blackwell. pp86-87
} 
knowledge policies, and research policies. ${ }^{75}$ In the decades after World War II these efforts were mainly a high-income country phenomenon, but in the 1970's low-income countries became more critical of high-income country policies and started prioritizing science and technology development as one of the paths to achieve self-reliance. ${ }^{76}$ Changes also include an expansion of the so-called third mission ${ }^{77}$ of universities along with theories that prescribe increased cooperation between universities, the state and industry such as some of the models described above.

A parallel can be drawn here to arguments by policy researchers Maarten Hajer and Hendrik Wagenaar about policy as an increasingly important method of governance. They are critical of the "widespread tendency among analysts to describe the changing reality in terms of key macro-sociological processes" such as technological development, globalization, and individualization. ${ }^{78}$ The main discussion in their case concerns the shift in vocabulary from government to governance in relation to changes taking place in politics and ways of governing. Hajer and Wagenaar are critical of those that claim that new vocabulary (such as governance and network management) is appearing in response to "the new reality of the network society". ${ }^{79}$ The same tendency can be identified in many foreign aid policies. Hajer and Wagenaar argue that even though this new vocabulary may in fact be reflective of radical changes taking place, there is a lack of rigorous analysis of what, more specifically, is new - and how.

\section{Changes in foreign aid}

As with the case of higher education and research, many changes have occurred in the policy and practice of aid during recent decades. To take a brief step further back, public foreign aid prior to World War II was primarily provided in the form of humanitarian relief or investments as part of colonial relations. ${ }^{80}$ The reasons for engaging in aid were diversified with the end of World War II, the UN was formed, the rate of decolonization increased and increased attention was paid to problems of low-income countries. The US was the dominating economic and military power in the period after WW II, and was highly influential in the creation of the IMF, the World Bank and the OECD for example. France and Great Britain were also major donors. ${ }^{81}$ Former US president Harry Truman's

\footnotetext{
${ }^{75}$ Benner, M. (2008). Kunskapsnation i kris. Politik, pengar och makt i svensk forskning, Nya Doxa. 66

${ }^{76}$ Shinn, T., J. Spaapen, et al. (1996). Science and Technology in a Developing World, Kluwer Academic Publishers. pp3\&11

77 For an interesting discussion about the "third mission", see Laredo, P. (2007). "Revisiting the Third Mission of Universities: Toward a Renewed Categorization of University Activities?" Higher Education Policy 20: 441-456.

${ }^{78}$ Hajer, M. and H. Wagenaar (2003). Deliberative Policy Analysis- Understanding Governance in the Network Society Cambridge University Press. p4

${ }^{79}$ Ibid. p4

${ }^{80}$ See for example Lancaster, C. (2006). Foreign Aid: Diplomacy, Development, Domestic Politics, The University of Chicago Press. pp25-27

${ }^{81}$ A Global Perspective on Research and Development (2009), UIS Fact Sheet, No. 2-09, UNESCO Institute for Statistics, Odén, B. (2006). Biståndets idéhistoria: från Marshallhjälp till millenniemål. Lund, Studentlitteratur. pp42-43
} 
speech from 1949 about the importance of counteracting underdevelopment in the world is often referred to as influential for Western aid policies to follow. These policies adhered to the modernistic catch-up ideas and high-income countries had to provide aid not only for the benefit of the low-income countries, but because of the security threats that underdevelopment posed. ${ }^{82}$

Economic growth, industrialization and modernization ideals dominated until the late 1960's, but in the 1970's critique against the focus on economic growth intensified. The lives of poor people had to be improved in order to able to say that development was occurring - distribution of resources became a central issue in aid policy. ${ }^{83}$ Oil prices were high and economic growth in high-income countries slowed down. Several large UN conferences took place which reflected the issues dominating development agendas, such as: the environment, world trade, food security, population, women's issues, technical cooperation, health care, housing and water. US influence as a donor was reduced but together with France and West Germany, they still provided a majority of the foreign aid. At the same time, Japan's foreign aid grew and Canada, the Netherlands and Scandinavian countries began having more impact in aid discussions. ${ }^{84}$

In 1980, there was a proposition put forth by the so-called Brandt report, to transfer massive amounts of funds to create a better balance between "North" and "South". Aid in the 1980's, however, was profoundly affected by the global debt crisis and the spread of neoliberal ideology (strongly supported by for example Margaret Thatcher and Ronald Reagan). Emancipatory ambitions and the priorities of the low-income countries shrunk in importance across the board, according to peace-and-development researcher Bertil Odén. The Brandt reforms were placed on ice, and aid attention turned to achieving macroeconomic stability. The role of the state was seen as diminished in importance and processes of privatization were encouraged by for example the structural adjustment programs of the IMF and the World Bank. ${ }^{85}$ Protests and critique from both high and low-income country actors (low-income country researchers, governments and NGO's for example) led to the "second generation" of structural adjustment programs which were more "humane", including some social safety nets. ${ }^{86}$

There have been profound changes in international relations after the end of the Cold War. Among other things, the "infrastructure of aid" has been rearranged, argue policy researchers Jacques Forster and Olav Stokke. ${ }^{87}$ Political scientist Kenneth King and

\footnotetext{
82 Odén, B. (2006). Biståndets idéhistoria: från Marshallhjälp till millenniemål. Lund, Studentlitteratur. p46

${ }^{83}$ Ibid. pp74-76

84 Ibid. pp82-83

85 Ibid. pp92-97

${ }^{86}$ See for example UNICEF's report Adjustment with a human face (1987). For a more detailed discussion on the effects of structural adjustments, see Limpach, S. and K. Michaelowa (2010). The Impact of World Bank and IMF Programs on Democratization in Developing Countries. CIS working paper No. 62 Center for Comparative and International Studies, ETH Zurich and University of Zurich.

${ }^{87}$ Forster, J. and O. e. Stokke (1999). Policy Coherence in Development Cooperation, Frank Cass \& Co. Ltd. pp1\&16-18
} 
international education researcher Simon McGrath agree and point out that the influence of the UN has since been reduced and been partially replaced by organizations such as the OECD and the WTO that are controlled by the wealthiest countries. They maintain that the expansion of the European Union as a development actor adds to this asymmetrical concentration of resources. In short, they suggest that aid is now more explicitly dominated by the interests of the richest countries. ${ }^{88}$

This view is also shared by Odén, who states that many influential countries became more focused on national interests in the beginning of the 2000's. ${ }^{89}$ King uses the UN Millennium Development Goals ${ }^{90}$ as an example and points out that although the policy rhetoric had become more focused on cooperation and joint capacity development (instead of knowledge and technology transfer), high-income country determined priorities nonetheless seem to have continued to dominate the agenda. ${ }^{91}$ Similar criticism is raised by peace and development researcher Maria Eriksson Baaz in her book The Paternalism of Partnership. She maintains that the need to create more equal relationships in development aid has been expressed in various ways using concepts like; ownership, participation and empowerment, but that research has shown that this proves difficult in practice. ${ }^{92}$

Aid can be provided for a number of reasons, official and unofficial ones. Altruism and solidarity are common explicit motivations, but reasons can also be to maintain stability and security through different kinds of presence and influence. There may be commercial or military interests as well. Odén gives the example of US and Soviet aid during the cold war; resources were strategically allocated in areas of conflict.93 Continued influence in former colonies has also been a motive, maintains Odén, like in the case of France, where aid flows up until the 1990's clearly followed this kind of pattern. The Scandinavian countries' aid, along with Canadian and Dutch aid has often been associated with motives based on solidarity, ${ }^{94}$ but this has recently changed; aid from these countries are increasingly serving national interests - as will be discussed more in the chapter on previous research.

\footnotetext{
${ }^{88}$ King, K. and S. McGrath (2004). Knowledge for Development? Comparing British, Japanese, Swedish and World Bank Aid. New York, Zed Books Ltd. p22-23

89 Odén, B. (2006). Biståndets idéhistoria: från Marshallhjälp till millenniemål. Lund, Studentlitteratur. p125

${ }^{90}$ Eradicate extreme poverty and hunger, Achieve universal primary education, Promote gender equality and empower women, Reduce child mortality rates, Improve maternal health, Combat HIV/AIDS, malaria, and other diseases, Ensure environmental sustainability, and Develop a global partnership for development, UN. "The UN Millenium Goals." Retrieved March, 2013, from www.un.org/millenniumgoals/.

${ }^{91}$ King, K. (2004). Development Knowledge and the Global Policy Agenda. Whose Knowledge? Whose Policy? Occasional Paper, . UNRISD Social Knowledge and International Policy-making: Can Research Make a Difference? Centre of African Studies, University of Copenhagen 92 Baaz Eriksson, M. (2005). The Paternalism of Partnership, Zed Books. p6

93 Odén, B. (2006). Biståndets idéhistoria: från Marshallhjälp till millenniemål. Lund, Studentlitteratur. pp13\& 31-36

${ }_{94}$ Ibid. pp13\& 31-36
} 
To put things into perspective; the amount of official foreign aid per year is relatively small when compared to several other financial flows in and out of low-income countries, such as foreign direct investment (FDI), for example, interest on loans, and private income transfers. Despite the fact that aid represents a relatively small amount of money in the bigger picture of global flows, activities and their effects cannot just be measured in financial terms. What this money does, how, and with what intentions and preconditions is obviously significant. Depending on whether the support is given to governments or to smaller NGO:s, for example, different parts and aspects of society are strengthened. Aid can have both intended and unintended consequences, but as Odén points out; giving direct budget support to governments tends to strengthen the leaders in power, while giving money to NGO:s to a larger degree strengthens civil society. ${ }^{95}$ Nevertheless, it is of relevance to contextualize aid financially since money can is one important indicator of political priorities.

\section{Theories about development}

"Development is a struggle of the shape of futures, a dramatic and complex struggle." 96 Which futures and paths are imagined, by whom, and what alternatives exist? Nederveen Pieterse maintains that development is a field in constant flux - a "high energy field" with challenges and setbacks together with successes and advances. Development theories are often grand theories about progress, and they can be seen as ideologies which depend heavily on political tides, or as an academic social science subject for example. A combination of both views is more contextual, development theory is influenced by both political processes and intellectual academic work. Development can according to this approach be defined as "the organized intervention in collective affairs according to a standard of improvement." 97

Development thinking is problem-driven rather than theory-driven, maintains Nederveen Pieterse, something which makes it "street smart" but also makes it rank "fairly low on the totem pole of social science" ${ }^{98}$ Development theory, he claims, is underestimated because it reflects a neocolonial division of labour in the production of knowledge. Below I have reproduced three tables from Nederveen Pieterse's book, on the meanings of development over time. They are of course simplifications, but they assist in understanding some of the trends.

\section{Table 2: meanings of development over time ${ }^{99}$}

\begin{tabular}{lll} 
Period & Perspectives & Meanings of development \\
\hline $1800 \mathrm{~s}$ & Classical political economy & Remedy for progress, catching-up \\
\hline
\end{tabular}

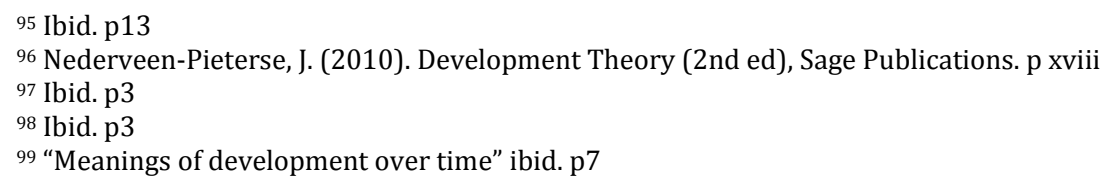




\begin{tabular}{|c|c|c|}
\hline $1870>$ & Latecomers & Industrialization, catching-up \\
\hline $1850>$ & Colonial economics & Resource management, trusteeship \\
\hline $1940>$ & Development economics & Economic growth, industrialization \\
\hline $1950>$ & Modernization theory & Growth, political and social modernization \\
\hline $1960>$ & Dependency theory & Accumulation - national, auto-centric \\
\hline $1970>$ & Alternative development & Human flourishing \\
\hline $1980>$ & Human development & Capacitation, enlargement of people's choices \\
\hline $1980>$ & Neoliberalism & $\begin{array}{l}\text { Economic growth, structural reform, } \\
\text { deregulation, liberalization, privatization }\end{array}$ \\
\hline $1990>$ & Post-development & Authoritarian engineering, disaster \\
\hline $2000>$ & Millennium Development Goals & Structural reforms \\
\hline
\end{tabular}

With the exception of dependency theory, alternative development and human development thinking, Nederveen Pieterse states, the theories have been produced in the West and in this way represent a "history of hegemony and political and intellectual Eurocentrism." 100 Each theory consists of many layers which should be taken into account when trying to understand them, for example its' historical and political context, what it aims to explain and how, and how it imagines futures. What these tables among other things illustrate is that ideas about development are historically contingent, as the section above on changes in foreign aid (above) exemplified.

\section{Table 3: Development perspectives and future options ${ }^{101}$}

\section{Theories and \\ definitions of \\ development}

\section{Modernization}

Development is state-led growth. Keynotes: industrialization, western model, foreign aid, linear progress, convergence

\section{Dependencia}

Development is underdevelopment (or dependent development) by comprador bourgeoisie; or stateled autocentric development (associated dependent development) by national bourgeoisie.

Neoclassical economics, neoliberalism
Revaluation of 'tradition', postmodernism, 'end of history', neomedievalism

Critique of newly industrialized countries, new international division of labour, social exclusion. Global political economy: power and economics, bring the state back in. Uneven global development
Future options

Modernities plural

Critique of uneven globalization

Financial crises. Market failure, safety net, human capital, good

100 Ibid. p9

101 "Development perspectives and future options". Ibid. p187 
Development is marked-led growth

Keynotes: overcome state failure through structural reform

(deregulation, privatization, liberalization) and get prices right

\section{Alternative development}

Development is society-led, equitable and sustainable

\section{Human development}

Development is capacitation. Human resource development is the means and end of development, measured in Human Development Index

\section{Post-development}

Development is destructive Immiserizing, authoritarian, past. Keynote: discourse analysis, critique of science and modernity governance, sustainability. Debt reduction. New institutional economics: institutional analysis
Coopted in mainstream.

Decentralization, professionalization. Alternative globalization.

Gender development index. Freedom development index, human security, global reform. Social and cultural capital.
Social development. Global justice
Social development. Global reform

There has been a convergence of sorts regarding the major perspectives on development, according to Pieterse, a growing reflexivity about both modernity and development and the available paths can now be found across the board. ${ }^{102}$ This has obviously not always been the case; the ideas above have clashed against one another in different ways during the period of Sarec's existence, sometimes quite explicitly. A short exploration of their major assumptions will be useful for the analysis to follow.

A central idea in modernization theory is that given certain preconditions, there is a set order to developments largely irrespective of local contexts. For example, the idea that agricultural societies will develop into industrial societies given certain set preconditions (economic ones mainly), and that countries needed to pass through one stage in order to get to the next one. ${ }^{103}$ Modernization and "Westernization" are not as attractive anymore, according to Nederveen Pieterse.104 Alternative views to development have emphasized context-dependence and the possibility of other futures than those following the paths of richer countries. In the table below, global power relations are mapped together with dominant paradigms in development thinking at the time.

\footnotetext{
102 Ibid. p182

${ }^{103}$ See for example Rostow, W. (1959). "The stages of economic growth." The Economic History Review, New Series 12(1): 1-16.

${ }^{104}$ Nederveen-Pieterse, J. (2010). Development Theory (2nd ed), Sage Publications. p1
} 
Table 4: Global hegemony and development theories ${ }^{105}$

\begin{tabular}{|c|c|c|c|}
\hline Historical context & Hegemony & Explanation & Development thinking \\
\hline Nineteenth century & British Empire & $\begin{array}{l}\text { Colonial anthropology } \\
\text { Social Darwinism }\end{array}$ & Progress, evolutionism \\
\hline 1890's-1930’s & $\begin{array}{l}\text { Latecomers, } \\
\text { colonialism }\end{array}$ & Classical political economy & Catching up \\
\hline Postwar boom & US hegemony & $\begin{array}{l}\text { Growth theory, structural } \\
\text { functionalism }\end{array}$ & Modernization \\
\hline Decolonization & $\begin{array}{l}\text { Third World } \\
\text { nationalism, NAM, } \\
\text { G77 }\end{array}$ & Neo-Marxism & Dependency \\
\hline $1980 s>$ & $\begin{array}{l}\text { Globalization, finance } \\
\text { and corporate capital }\end{array}$ & Neoliberalism, monetarism & Structural adjustment \\
\hline $1990 s>$ & $\begin{array}{l}\text { Rise of Asia, big } \\
\text { emerging economies, } \\
\text { BRIC }\end{array}$ & $\begin{array}{l}\text { Capabilities, } \\
\text { developmental state }\end{array}$ & Human development \\
\hline
\end{tabular}

The conflict is now between human and alternative development on the one hand and neoclassical economic politics on structural reform on the other. ${ }^{106}$ Actual development, though, "involves continuous traffic back and forth across the spectrum" of different views, maintains Nederveen Pieterse. ${ }^{107}$ Understandings of development today are more multidimensional than in the past - both "hard" and "soft" aspects ${ }^{108}$ are considered important - and "Western" perspectives exist alongside perspectives from the South and East. ${ }^{109}$ An example of recent consensus among development policy-makers as well as researchers is that in order for knowledge and technology to be adequate and relevant in any given context, its development and/or application needs to be driven by endogenous processes. ${ }^{110}$ In other words, critique towards excessively donor-driven approaches has been strong. According to anthropologist Arjun Appadurai, this kind of critique was not as common in the heyday of modernization theories:

In an earlier, more confident epoch in the history of social science-notably in the 1950s and 1960s during the zenith of modernization theory-such epistemological diffidence would have been quickly dismissed, since that was a period when there

\footnotetext{
105 "Development perspectives and future options" (table11.1), ibid. p10

106 Ibid. p84

107 Ibid. p189

${ }^{108}$ Hard: infrastructure, capital and technology. Soft: institutions, processes, management, education and knowledge

${ }^{109}$ Nederveen-Pieterse, J. (2010). Development Theory (2nd ed), Sage Publications. p189

110 See for example Howitt, P. (2004). Endogenous Growth, Productivity and Economic Policy: A

Progress Report. International Productivity Monitor 3-15.
} 
was a more secure sense of the social in the relationship between theory, method, and scholarly location. Theory and method were seen as naturally metropolitan, modern, and Western. The rest of the world was seen in the idiom of cases, events, examples, and test sites in relation to this stable location for the production or revision of theory. Most varieties of Marxist theory, though sharply critical of the capitalist project behind modernization theory, nevertheless were equally "realist," both in their picture of the architecture of the world system and in their understanding of the relationship between theory and cases. Thus much excellent work in the Marxist tradition had no special interest in problems of voice, perspective, or location in the study of global capitalism. In short, a muscular objectivism united much social science in the three decades after World War II, whatever the politics of the practitioners. ${ }^{111}$

As shall be shown, the changing ideas about development are visible in the policy development of Sarec. Nederveen-Pieterse maintains that even though different development actors - such as large international organizations, states or NGOs - have different perspectives and policy preferences; "seen up close, each position itself is a cluster of positions and an arena of different views." 112 It is to be expected, in other words, that a variety of theoretical perspectives exist in aid actors policies for example.

The terminology used in the development field has changed over the decade, as illustrated by the tables above. Concepts that became common after the decolonization process according were modernization, industrialization, development and third world.113 Though all the concepts are still in use, there has also been a shift from for instance technology transfer to development cooperation and capacity building. ${ }^{114}$ There are many buzzwords that represent different views and relations to concepts of development. ${ }^{115}$ The focus, however, still largely remains on gaps, implying that "modernization" or "linear" thinking continues to exist alongside more pluralistic ideas. This can be partly illustrated by the knowledge divide example from the UNESCO report below. The authors essentially argue that developments in high-income countries can and will occur in the same way in low-income countries given the right circumstances:

The experience of developed countries shows that the private sector investment in $R \& D$ increases when the research environment and facilities improve in the

\footnotetext{
${ }^{111}$ Appadurai, A. (2000). "Grassroots Globalization and the Research Imagination." Public Culture 12(1): 1-19. p4

112 Nederveen-Pieterse, J. (2010). Development Theory (2nd ed), Sage Publications. p188

${ }^{113}$ See for example Shinn, T., J. Spaapen, et al. (1996). Science and Technology in a Developing World, Kluwer Academic Publishers.

${ }^{114}$ See for example Whyte, A. (2004). Landscape Analysis of Donor Trends in International Development. Human and Institutional Capacity Building. t. R. Foundation., and Kenny, S. and M. Clarke (2010). Challenging capacity building: comparative perspectives rethinking international development Palgrave Macmillan 115 See for example Cornwall, A. (2007). "Buzzwords and fuzzwords: deconstructing development discourse." Development in Practice Vol 17:4(4): 471-484 and Biccum, A. R. (2005). "Development and the 'New' Imperialism: a reinvention of colonial discourse in DFID promotional literature." Third World Quarterly 26(6): 1005-1020.
} 
country. Therefore, the initial investments to strengthen research capacity in developing countries have to come from public sources. ${ }^{116}$

King and McGrath suggest that discourse has changed more than practice. The "new" positively loaded discourse of globalization, partnership, capacity building and poverty reduction may serve to maintain old power relations by new means. Policy researcher Osita Ogbu for example, maintains that "colonialism was anti-indigenous knowledge and technology. It created a legacy of knowledge and technology dependency that is still very much in evidence." 117 He claims that Africa repeatedly goes through "forced technological transitions" driven first by colonialism, then by postcolonial ties and now by globalization. The most recent driving force, according to him, is not as concerned with low-income country capacities as it is with consumerism. ${ }^{118}$

\section{Research and aid coming together}

Direct research cooperation between universities in high-income and low-income countries is not a new phenomenon, and international aid actors have also long worked to harness the benefits of science and technology for development. Organizations like the UN and the World Bank are important to address here given that their policies strongly influence other aid actors. The UN, for example, has worked with issues of research for development in different forms since its inception by among other things organizing global conferences on the topic. The first conference was in Geneva in 1963 - "UN Conference on the Application of Science and Technology for the Benefit of the Less Developed Areas" (UNCSAT) in Geneva. ${ }^{119}$ According to a working document by KlausHeinrich Standke (then at UNESCO), the intention of the conference was to discuss the need for low-income countries to build their own science and technology capabilities, but only $16 \%$ of the near 1700 delegates were from low-income countries. Though this first UN conference of its kind was considered a failure due to the lack of concrete policy results, it is thought to have lifted the importance of science and technology policy on the development agenda. ${ }^{120}$ Many more such conferences followed.

The World Bank has also given attention to these issues for several decades, though primary and secondary education were given higher priority until the 1990's, ${ }^{121}$ when there was a significant upsurge of "knowledge-related" activities in relation to

\footnotetext{
116 Sanyal, B. C. and N. V. Varghese (2007). Research Capacity of the Higher Education Sector in Developing Countries, International Institue for Educational Planning, UNESCO. p2 117 Ogbu, 0. (2006). The demand for policy research in Africa. Science and Technology Policy for Development: Dialogues at the Interface. L. Box and R. e. Engelhard, Anthem Press. p27 118 Ibid.

119 Jolly, R., L. Emmerij, et al. (2004). UN contributions to development thinking and practice, Indiana University Press. pp95-96

${ }^{120}$ Standke, K.-H. (1997). Overview of past multilateral Conferences on Science and Technology. Third Meeting of the Steering Committee of the International Scientific Advisory Board of UNESCO. UNESCO. pp4-5 121 (2000). Higher Education in Developing Countries - Perils and Promise. The Taskforce on Higher Education and Society. T. W. Bank. p10
} 
higher education and research. ${ }^{122}$ Previous to that it was considered unnecessary to contribute to low-income country knowledge-building capacity since knowledge could be transferred/imported from aid organizations or other countries instead. ${ }^{123}$ The World Bank and the International Monetary Fund (IMF) were responsible for the Structural Adjustment Programs imposed in return for loans (during the 1980's and 1990's), programs which are often considered to have contributed negatively to the development of low-income countries and their education systems. ${ }^{124}$

Research as part of national foreign aid efforts appeared in a few different forms during the 1950's and 1960's and added another type of actor into the equation high-income country development agencies with goals pertaining to development and poverty reduction. The basis for cooperation is different compared to when international research partnerships are established between universities without the added explicit goal of contributing to each other's research capacity or producing results of direct development relevance. The number of high-income country aid agencies and international development organizations ${ }^{125}$ involved in supporting higher education and research in low-income countries has increased since the beginning of the 1970's, ${ }^{126}$ but especially since the middle of the 1990's. With the goal to reduce the "research gap", aid actors provide various types of support to improve the research capacity 127 of low-income countries. A search through the strategies and policies of high-income country development agencies ${ }^{128}$ shows that higher education and research is on a majority of these actors' development agendas, although methods of support and levels of priority vary. ${ }^{129}$ According to a study by the Overseas Development Institute (ODI), there were at

122 See for example Higher Education: Lessons for Experience (WB, 1994), Knowledge for Development (WB, 1999), Higher Education in Developing Countries: Peril and Promise (WB, 2000), Science and Technology Collaboration: Building Capacity in Developing Countries? (WB, 2001), and Constructing Knowledge Societies: New Challenges for Tertiary Education (WB, 2002).

${ }^{123}$ Sida (2006). Time for Rethinking. Capacity Development in a Changing Landscape of Development Cooperation. p39

124 See for example Babb, S. (2003). "The Social Consequences of Structural Adjustment: Recent Evidence and Current Debates." Annual Review of Sociology 31: 199-222, and Easterly, W. (2005). "What did structural adjustment adjust? The association of policies and growth with repeated IMF and World Bank adjustment loans, ." Journal of Development Economics 76: 1-22. 125 Aid agencies and similar organizations engaging in research for development in some way will sometimes collectively be referred to as research aid actors. I will use research aid as a term that encompasses all activities that aim to improve the research capacity of low-income countries - whether it is on individual, organisational, or policy levels.

126 Gaillard, J. (1990). "Science in the developing world: foreign aid and national policies at a crossroad." Ambio 19: 348-353.

${ }^{127}$ I will discuss definitions of capacity later, but an example of a definition of research capacity is that of the British DFID: "the ability of individuals, organizations and systems to undertake and disseminate high quality research effectively and efficiently" (From DFID:s Research Strategy 2008-2013)

${ }^{128}$ Such as development agencies in Austria, France, Germany, the UK, the Netherlands, USA, Denmark, and Canada

129 The UK for example, doubled its spending on research for development 2008-2013 (See DFID Research Strategy 2008-2013, UK Department for International Development) 
least 49 such research aid actors (of larger size) in 2001. The top three bilateral donors in research aid were the Netherlands (NUFFIC), Canada (IDRC), and Sweden (Sida), and the areas given most funding in total were health, agriculture and economic research. ${ }^{130}$

This focus on creating links between research and development policy has, according to political scientists Eleanor Fisher and Jeremy D. Holland revived a number of old questions in new ways; how should research be related to policy making, what should the role of public funding be in capacity building and the production of knowledge, and how are research capacities effectively strengthened? ${ }^{131}$ Discussing this same attempt to bridge theory and practice, development policy researchers Julius Court and Simon Maxwell maintain that the policy debate on these issues is often too transnational in nature; "the typical developing country debate is much influenced by the international zeitgeist, as represented by World Bank or UN reports."132 This will be discussed in more detail in the chapter on previous research, but several critics maintain that North-South research partnerships have been dominated by Northern agendas and that effects on development are questionable. ${ }^{133}$ In light of this, it is of interest to analyze the policy development of one of the aid actors which has been referred to as strongly solidaritybased for much of the post-war period.

\section{Research aid - symptomatic of the "knowledge society?"}

According to Marybeth Long Martello and Sheila Jasanoff (2004) there has been "a shift from science as the primary cognitive resource for addressing global-scale social and ecological challenges to the broader category of "knowledge."134 This, they maintain, has been facilitated not least by the gradual realization that environmental problems are global and require cooperation. International environmental regimes increasingly admit that local, traditional and indigenous knowledges may serve as useful instruments for sustainable development and for connecting with "on-the-ground" political constituencies." They claim that local epistemologies have recently been ascribed more value, Western science is not the only valid knowledge. ${ }^{135}$ They maintain that early development programs (no specific ones mentioned) tried to build capacity in the image of "Western-know-how" whereas there now seems to be more respect for local forms of knowledge - that is - other knowledge than "Western" scientific knowledge. 136 There are differing opinions as to whether this is the case, but the concept of knowledge society has nevertheless become a hot topic.

\footnotetext{
130 Young, J. and N. Kannemeyer (2001). Building Capacity in Southern Research: A Study To Map Existing Initiatives. O. D. I. (ODI).

131 Fisher, E. and D. Holland (2003). "Social development as knowledge building: research as a sphere of policy influence." Journal of International Development 15(7): 911-924. p912

${ }_{132}$ Court, J. and S. Maxwell (2005). "Policy entrepreneurship for bridging poverty reduction:

Bridging research and policy in international development." Ibid. 17: 713-725. p717

${ }^{133}$ See for example Menon, V. and K. N. Nair (2002). Capacity Building for Demand-led Research:

Issues and Priorities Maastricht: European Centre for Development Policy Management. p14

134 Jasanoff, S. and M. Long Martello (2004). Earthly Politics, The MIT Press. p9

135 Ibid. p15

136 Ibid. p20
} 
The dominant discourse of the knowledge society - somewhat simplified assumes a positive relationship between knowledge, innovation, and socio-economic development. Definitions vary greatly, but according to Nico Stehr, a knowledge society is one where all spheres are penetrated by scientific and technical knowledge. ${ }^{137}$ The concept was coined in the late 1960 's, ${ }^{138}$ but became more widely used in the 1990's. ${ }^{139}$ Other related terms that are sometimes used interchangeably are knowledge economy, information society, and network society - the definitions overlap in many respects. Knowledge has been considered an important driver of development for a very long time. A valid question to ask, therefore, is what the novelty is. Nevertheless, knowledge has come to be considered increasingly central for social and economic development in recent decades. ${ }^{140}$

National innovation systems, for example, have actively been exported, "transferred" or pursued in low-income country contexts. How much the focus lands on "hard" sciences and economic growth varies depending on which school of research one looks at, or which aid actor, but nevertheless - innovation systems are often framed as being able to solve all kinds of development problems (innovation, economic growth and poverty reduction go hand in hand, in this view) as exemplified by this quote from a report by the OECD from 2012:

Innovation can make a difference in addressing urgent developmental challenges such as providing access to drinking water, eradicating neglected diseases or reducing hunger. The transfer and, when necessary, adaptation of technologies developed in developed countries can often contribute significantly to these goals. Substantial research efforts are needed to find solutions that address other global challenges. Effective international cooperation that involves both public and private bodies is an important mechanism for finding these much-needed solutions. Moreover, one of the important lessons of the past two decades has been the pivotal role of innovation in economic development. The build-up of innovation capacities has played a central role in the growth dynamics of successful developing countries. These countries have recognised that innovation is not just about high-technology products and that innovation capacity has to be built early in the development process in order to possess the learning capacities that will allow "catch up" to happen. ${ }^{141}$

\footnotetext{
137 Stehr, N. (2005). Knowledge Politics: Governing the Consequences of Science and Technology., Paradigm Publishers. p12

138 To the best of my knowledge, the concept was coined by Drucker, P. F. (1969). The Age of Discontinuity - Guidelines to Our Changing Society, Harper and Row.

${ }^{139}$ See for example UNESCO (2005). Towards Knowledge Societies. pp17-18

140 See for example Etzkowitz, H. and L. Leydesdorff (2000). "The dynamics of innovation: from National Systems and "Mode 2" to a Triple Helix of university-industry-government relations." Research Policy 29. P109 and Benner, M. (2008). Kunskapsnation i kris. Politik, pengar och makt i svensk forskning, Nya Doxa. p17

141 OECD (2012). Innovation for Development. A discussion of the issues and an overview of work of the OECD Directorate for science, technology and industry. p4
} 
The quote exemplifies a kind of marriage that seems to have occurred between linear and systemic models of knowledge and development; the emphasis on local conditions and contexts is combined with general or universal models for development.

\section{A glimpse into the practice of research aid}

This study focuses more on the policy discourse of the research aid actor than on the organization per se, yet a glimpse into what different research aid actors do is a relevant background to have in order to understand Sarec.

International and multilateral aid actors such as the World Bank, the UN and the European Union differ greatly in methods and goals pertaining to research for development. Some of them work with clear capacity building goals; others conduct and/or fund development research, and others do both. In addition to the abovementioned types of actors there are charitable foundations that fund research for development (such as the Bill and Melinda Gates foundation, the Wellcome Trust or the Rockefeller Foundation) and many organizations that work on spreading news and information about research for development, such as the Science and Development Network. ${ }^{142}$

It is important to distinguish between support to development research and support to building research capacity - the two are related in many cases but have slightly different goals. Development research is research which has more or less direct relevance to the solving of problems facing low-income countries, but it is not necessarily only conducted there - certain research on agricultural or medical technologies for example. When the goal is to contribute to the building of research capacity in low-income countries, however the research process itself and its surrounding prerequisite conditions are the priority. The main goal might be to contribute to an increased number of doctoral graduates or to assist in research policy management. The specific areas of research involved and their development relevance are certainly not irrelevant, but of secondary importance.

The support from research aid actors may consist of activities such as split research training programs for low-income country students to attain MSc's and PhD's, the financing of infrastructure (such as labs and ICT), assistance with national and/or local education and research policies, support to research networks between low-income countries, and direct research project funding. Most of these activities occur with varying levels of collaboration with high-income country universities - regardless of whether the focus is on capacity building or development research.

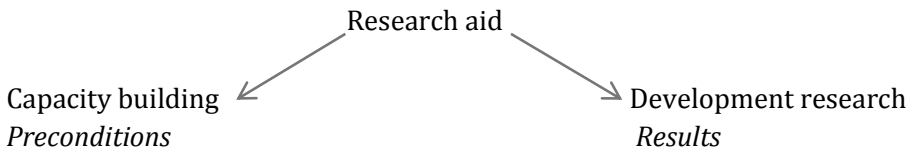

142 The Science and Development Network, www.scidev.net (accessed Jan 2011) 
The level of research aid actor that I am focusing on in this thesis is the national aid agency level. National aid agencies comprise a different type of research aid actor which to a higher degree than other actors focuses on contributing to building research capacity in low-income countries. Examples are the Canadian International Development Research Centre (IDRC), the Netherlands organisation for international cooperation in higher education (Nuffic), and the Swiss Commission for Research Partnerships with Developing Countries (KFPE). The long-term goal with their activities is to contribute to development (for example economic growth and/or poverty reduction). The research aid strategies of different country agencies have many components in common, they can encompass for example:

- supporting specific research projects in low-income countries in bilateral cooperation with universities in donor high-income countries

- assisting with, or creating, training programs for researchers (carried out in high-income countries, low-income countries, or both),

- supporting the building of important infrastructure (such as information and communication technology, administration systems, or labs),

- supporting the development of national, regional, and international research networks, or

- directly financing research for development and poverty reduction (in high-income countries, low-income countries, or both).

Some place larger emphasis on for example training programmes or infrastructure, while others focus more on policy level efforts, and others do all of the above. Sometimes cooperation with other actors in industry and civil society are encouraged or demanded.

\section{Actors}

International// $\underbrace{\text { multilateral }}_{\text {Low-income and high-income universities }}$

\section{A note on capacity development}

Many aid actors work with a 'capacity building' or 'capacity development' perspective, an approach which has been developed to a large extent through the practice of development organizations. ${ }^{143}$ Given the centrality of capacity in research aid I will discuss it in some detail here. The origins and evolution of capacity building are diverse and have been strongly influenced by aid actor practice, but also institutional economics (in the 1950's and 1960's), human resource development (1970's and 1980's) and ideas about knowledge networks. It is characterized by participatory approaches and local ownership. ${ }^{144}$ Horton et al combine definitions from various development organizations

${ }^{143}$ Horton, D. (2003). Evaluating capacity development experiences from research and development organizations around the world. The Hague :, ISNAR ;. p33

${ }_{144}$ Blagescu, M. and J. Young (2006). Capacity Development for Policy Advocacy: Current thinking and approaches among agencies supporting Civil Society Organisations, ODI: 56. 
like the United Nations Development Program (UNDP) and the Red Cross and offer the following definition of organizational capacity building:

\begin{abstract}
...an ongoing process by which an organization increases its ability to formulate and achieve relevant objectives. It involves strengthening both its operational and adaptive capacities....[it] is undertaken through its own volition. It is carried out through the application of the organization's own resources, which may be supplemented with external resources and assistance. External support for organizational capacity development can take different forms, including provision of financial resources, technical expertise, training, information, political negotiation, and facilitation of capacity development processes. ...The objective...is to help improve organizational performance to address known issues and react to emerging issues that arise in today's rapidly changing world. ${ }^{145}$
\end{abstract}

The authors maintain that in order for capacity building to work, the efforts cannot solely focus on for example individual competence building or physical equipment - all aspects of the organization and its context (individual, organizational and policy) need to be addressed. ${ }^{146}$ The organizations themselves have to be ultimately responsible for the process, and external resources and assistance should be adapted to the organization's needs and priorities. Hence, 'supply-driven' capacity development; where the external actors, based on their specific development goals, define which assistance to offer, is considered problematic and can have negative effects on the organizations in question. ${ }^{147}$

Some definitions surrounding capacity are more detailed than others. Sida's general definition of capacity development is "the combined efforts to support the development of knowledge, competence and well-functioning organisations and institutions." 148 Sida also claims that the end goal of building capacity is wider than increasing competitiveness:

The ultimate objective of the development of knowledge and capacity is therefore to make it easier for people to build up an identity: for themselves and in relation to others. To speak about knowledge and capacity as "the true humanist mission of education" is not in conflict with the idea of knowledge and capacity as means to increase productivity. Knowledge and capacity are tools, but not tools that serve solely to increase productivity. They also help give people an identity and enable them to participate fully in social and political life. ${ }^{149}$

Similar discussions concerning capacity can be found in several other aid actor policies and reports. To tie back to the discussion about gaps in the beginning, this increasing focus

\footnotetext{
${ }^{145}$ Horton, D. (2003). Evaluating capacity development experiences from research and development organizations around the world. The Hague :, ISNAR ;.

146 Ibid.

147 Ibid.

${ }^{148}$ Sida (2000). Sida's Policy for Capacity Development a Strategic Question in Development Cooperation p15

149 Ibid.
} 
on 'capacity' in aid policies could be seen as indicative of a changing view of development amongst high-income country aid actors from a linear stage view to a more systemic one. The Swiss KFPE, for example, is quite explicit in this regard:

\begin{abstract}
A major paradigm shift has been taking place in development-oriented research that focuses on the nature of knowledge production and the social validation, diffusion and utilisation of knowledge. The linear model of scientific innovation - based on the view that a problem crops up in reality, is then addressed by science, which then finds a solution, which is then applied in reality - has been replaced by models insisting on the continual interaction between science and society, on learning processes, and on networks. In development-oriented research, science is now perceived as a system of innovation that produces knowledge in interaction with the social context for which research results will be relevant. This more holistic approach to knowledge creation and technology development is also advocated for North-South research partnerships. ${ }^{150}$
\end{abstract}

Other aid actors are using this type of terminology as well, referring to national knowledge or science systems for example. The changes in terminology might in some cases be clearer on paper than in reality. ${ }^{151}$ The existence of other interests (financial, political) and path dependence may result in quite different practice. The terminology and arguments used in the policies are nevertheless interesting to analyze. Development researchers Sue Kenny and Matthew Clarke maintain that the various meanings of capacity building tend to be taken for granted within aid, but it is attractive because it aims at enabling people to have increased control over their own lives. It is often placed against things like structural adjustment programs and "top-down social engineering". 152

Having discussed some definitions and problems surrounding 'capacity' and 'capacity building' - I will discuss ways of defining 'research capacity'. The ability of a university to function and fulfil its goals is seen by many development agencies to depend on its capacity. A UNESCO report summarizes research capacity as consisting of the following:

- Capable researchers (for example faculty, research staff, graduate students)

- Time (excessive amounts of teaching and administration can keep researchers from living up to their research potential)

- Infrastructure (laboratories, libraries, administration systems, computational resources)

- Research climates (support from politicians, the public, and the media in creating a climate where research and researchers are valued)

- Funding (predictable levels of support over time)

\footnotetext{
150 Sieber, P. and T. Braunschweig (2005). Choosing the Right Projects. Designing Selection Processes for North-South Research Programmes, KFPE . p11

${ }^{151}$ See for example Cornwall, A. (2007). "Buzzwords and fuzzwords: deconstructing development discourse." Development in Practice Vol 17:4(4): 471-484

152 Kenny, S. and M. Clarke (2010). Challenging capacity building: comparative perspectives rethinking international development Palgrave Macmillan pp3-4
} 
- Structural conditions (optimal use of resources and facilities in order to avoid unnecessary dispersion or duplication)

- Research ethics (codes of ethics prevent conflicts of interest and other pressures, and enables transparency)

- Critical perspective (critique and feedback to keep research from becoming self-serving and introvert) ${ }^{153}$

There are of course other definitions but they all more or less have in common a systemic perspective. The Department for International Development (DFID) in the UK defined research capacity as:

...the ability of individuals, organisations and systems to undertake and disseminate high quality research effectively and efficiently. There is, in addition to the three levels in the definition, the 'institutional' context in which capacity building takes place. This covers the incentives, the economic, political and regulatory context and the resource base on which the context is built. ${ }^{154}$

Even though the definitions can be considered similar, the strategies and activities undertaken by different donors vary considerably.

\section{Other central terminology}

In addition to capacity building, there are several concepts and terms that are central; science, technology, research capacity, or development for example. ${ }^{155}$ Some of these have been partly defined in this chapter, and others will be discussed in chapters two to four. The most relevant definitions of central concepts given my purpose, however, are the ones provided by the empirical material, hence I will analyze how the different materials over time relate to and define central concepts. The study is a discourse analysis of ideas within Swedish research aid, hence attempting to provide some sort of standard definitions a priori is not as interesting as comparing the ones that develop over time in the material. These definitions can then in turn be contrasted to previous research for instance, but I do not provide any "closed" definitions.

\footnotetext{
153 Weiler, H. N., S. Guri-Rosenblit, et al. (2006). Universities as Centres of Research and Knowledge Creation: An Endangered Species? Summary report from Colloquium on Research and Higher Education UNESCO. pp 2-4 154 DFID research strategy 2008-2013, Working Paper Series: Capacity Building (2008), Department for International Development (DFID)

155 Research and science are sometimes used interchangeably.
} 


\section{Theoretical perspectives}

...the predominance of the Western research tradition is not a matter of a conflict between "developed" and "undeveloped" thought, or of a "scientific" versus a "primitive" quality. It is a matter of differences of knowledge and intellectual specialization, which are ultimately due to differences in material resources, social organization, intellectual traditions and systems of values between different cultures. ${ }^{156}$

- Sarec's first annual report

The quote above frames different kinds of research traditions in an equal manner, objecting to the kind of differentiation that depicts Western science as superior. The policy documents that Sarec and other aid actors publish construct specific ideas about the role of science and technology in development; ideas about different knowledge systems for example, as exemplified by the quote above. This also implies that there are a number of alternatives that are not imagined - or "made possible" at any given time. Universities in low-income countries often provide higher education to a very large number of students for example, but without also having strong research it may not be considered an optimally functioning university. One point of departure in this study is that research aid policies affect how researchers and universities in low-income countries are perceived, and also to some extent affect the choices available to these researchers and universities. Policy is politics.

Discourse theory, according to political theorist David Howarth, is theory that assumes that the meaning of objects and actions is a "product of historically specific systems of rules". ${ }^{157}$ Discourse can be defined quite narrowly, as single utterances or conversations, or it can be conceptualized more widely, as branch-specific language or entire systems of meaning. ${ }^{158}$ Schools of discourse analysis may be placed on a scale from structuralist/realist to post-structuralist/constructivist. Somewhat simplified: structuralist accounts see physical and material resources first and foremost as creating the preconditions (possibilities as well as limits) for certain discourses whereas poststructuralist accounts underline the significance of discourses in shaping and constituting the physical and material world and our perceptions of it. ${ }^{159}$ Discourse theorists are interested in "how, under what conditions, and for what reasons, discourses are constructed, contested and change". ${ }^{160}$ Discourse analysis refers to analysis of how discursive forms and practices are signified, and this is done by using a variety of qualitative methods including document analysis and interviews. ${ }^{161}$

\footnotetext{
${ }^{156}$ Sarec (1977). Sarec's First Year, Annual Report 1975/1976. pp8-9

${ }^{157}$ Howarth, D. (2000). Discourse, Open University Press. p8

158 For a discussion on this see for example ibid. pp2 \& 9

159 Ibid. pp2-3

160 Ibid. p131

161 Ibid. pp10 \& 140
} 
In this study, I employ discourse theory and analysis to interpret how research policy discourse in the context of Swedish official foreign aid has been imagined and portrayed since the 1970's. Through an analysis of documents and interviews, I identify how for example the role of science and technology in development is discursively constructed; how researchers, universities and aid actors are seen to play into this and how these conceptions evolve over time. My ambition has been to analyze this development while also being able to make sense of the empirically informed literature on development and knowledge that is more or less explicitly embedded in the material.

The purpose of this chapter is to discuss how discourse theory together with certain perspectives and concepts from Science and Technology Studies provide relevant points of departure for this study.

\section{Framing the construction of research aid-theories of discourse}

Discourse theory and analysis have their roots in both structuralist and post-structuralist linguistic philosophy which portrayed language as a system of signs that is given meaning through social conventions. ${ }^{162}$ Linguist Ferdinand de Saussure (1857-1913) was among the first to claim that words (or signs) gain meaning in relation to other words as opposed to the phenomenon or physical object it refers to - relations that can change over time depending on social conventions. ${ }^{163}$ To take a very concrete example, the word "bag" could refer to something we carry things in during one period or context and something entirely different in another period or context, but "bag" always gets its' meaning from other words which represents other things. A bag is not a guitar for example.

Saussure distinguished between language as structure, which he considered a stable system of rules and relations, and language in use. He believed that language in use was much too messy to merit study. ${ }^{164}$ Post-structuralists such as Jacques Derrida, Roland Barthes and Michel Foucault rejected this sharp distinction and claimed that language as structure was in fact much less stable and more subject to inconsistencies than Saussure had claimed. Words or signs do get their meaning from their relation to each other - but these relations can differ and words can have different meanings depending on the context in which they are used.165 The word "wicked" can be either something very negative or something very positive depending on who is using it, when and in what context. Post-structuralists argued that this fact made language in use the more interesting study object since this was where the differences and changes in meaning could be observed. ${ }^{166}$

I will define my own position more specifically throughout the chapter, but my point of departure is towards the post-structuralist or constructivist end of the scale.

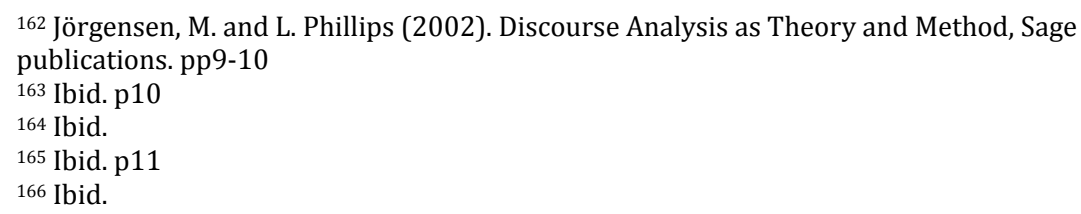


On a general level, many of the post-structuralist discourse analysts share the view that language is not a neutral reflection of "reality"; our access to the material or physical world is through language. ${ }^{167}$ Language enables us to create representations of physical objects and material resources and these representations contribute to constructing reality. Furthermore, what we count as valid knowledge is historically and culturally specific - it could have been otherwise. ${ }^{168}$ Certain ideas or actions may be acceptable in one time and place while others are deemed unthinkable.

I have chosen use Foucault's theory about discourse as a general point of departure in this study, and I will start with a discussion about some of his central arguments and concepts. Foucault's ideas will then be complemented by more contemporary discourse theory, focusing mainly on Norman Fairclough's conceptualization of discourse which assists in more concretely framing my object of study. Foucault and Fairclough are not applied in a reverent manner. I borrow some perspectives and conceptualizations that I find useful for contextualizing, understanding and explaining my study of Swedish research aid. I discuss some of the areas where they harmonize and overlap, and some points of potential contention. Concepts used within of STS - sociotechnical imaginaries and boundary organization - complement discourse analysis and together they make my theoretical framework somewhat of a patchwork quilt in that sense, but one sewn together in a robust manner and enabling a multi-faceted analysis.

\section{Discourse according to Foucault}

Foucault is often categorized as being post-structuralist, though many argue that his early work was semi-structuralist and he himself generally seemed to be against categorizations of this sort. ${ }^{169}$ Discourse analysis post-Foucault has been developed and applied in a wide variety of fields and with quite different emphasis and methodology. ${ }^{170}$ Most contemporary discourse analysts agree with Foucault's basic theoretical claims, or at least use them in some way. ${ }^{171}$ In addition to differing in terms of how realist or constructivist they are, they vary regarding scope and levels of analyses.

Foucault's definition of discourse varies but one is "practices that systematically form the objects about which they speak." 172 How we act and talk in relation to an object defines to a large extent what that object becomes. To take an example, the object development is systematically and actively constructed and contested through acts and statements that reinforce certain values and beliefs while excluding others. Objects, furthermore, can be seen as central building blocks, essential parts of what

\footnotetext{
167 Ibid. p8

168 Ibid. pp5-6

169 Nilsson, R. (2006). Foucault - en introduktion, Egalité. pp11-12

${ }^{170}$ For example critical discourse analysis, discursive psychology, the Essex school

171 Jörgensen, M. and L. Phillips (2002). Discourse Analysis as Theory and Method, Sage

publications. p13

172 Dreyfus, H. L. and P. Rabinow (1983). Michel Foucault. Beyond Structuralism and

Hermeneutics (2nd ed), The University of Chicago Press. p62
} 
characterizes any specific discourse. In a similar manner to social theorist Walter Bryce Gallie's essentially contested concepts ${ }^{173}$, these central objects (such as development or capacity) may be defined quite differently within the same certain field for instance (intentionally or unintentionally) or it can be widely used without really being defined at all. They are concepts which enable a diversity of uses. ${ }^{174}$

Another definition of discourse is "historically specific systems of meaning which form the identities of subjects and objects." 175 Specific possibility conditions are constructed by both discursive and "non-discursive" practices according to Foucault, and these possibility conditions determine what can be considered knowledge and knowing during a specific historical period.176 Foucault believed in a principle of "ontological discontinuity" - continuities and causal mechanisms were to be challenged. ${ }^{177}$ He strongly maintained the post-structuralist standpoint that there is no one history, just as there is no correct grand and all-encompassing theory. ${ }^{178}$ One has to analyze from a specific perspective.

The empirical studies of Foucault focus on how norms and knowledge are made legitimate and objective. ${ }^{179} \mathrm{He}$ was interested in power and knowledge - not least claims to truth through the use of scientific knowledge: "through his studies of psychiatry, biomedicine, penology, sexuality and various bodies of political knowledge, Foucault explored how such forms of knowledge informed and enabled the exercise of power". ${ }^{180}$ Identifying underlying meaning was not the purpose with the type of studies he conducted. The analyses do not lend themselves to empirical generalizations; instead they examine what the political uses of certain knowledge production can be for example, and show how it is possible to think in a certain way. 181 One example that he provides is the "idea of the university." This idea makes possible a certain mix of "things" in a university system; the institutions and practices of that particular time must sustain the discourse; otherwise it cannot "fulfill" that particular idea of the university. ${ }^{182}$ During the 2000's it has become more common to have "innovation offices" at Swedish Universities for

\footnotetext{
173 See for example Collier, D., F. D. Hidalgoa, et al. (2006). "Essentially contested concepts: Debates and applications." Journal of Political Ideologies 11(3): 211-246. pp211-212 \& 236 ${ }^{174}$ Another way to discuss this phenomenon is to use the term "plasticity", defined as "the ability to be easily molded or to undergo a permanent change in shape" by the Oxford English Dictionary (www.oed.com) 175 Howarth, D. (2000). Discourse, Open University Press. p9 176 Dreyfus, H. L. and P. Rabinow (1983). Michel Foucault. Beyond Structuralism and Hermeneutics (2nd ed), The University of Chicago Press. p69

177 Nilsson, R. (2006). Foucault - en introduktion, Egalité. p52

${ }^{178}$ Ibid. pp168 \& 182

179 Dreyfus, H. L. and P. Rabinow (1983). Michel Foucault. Beyond Structuralism and Hermeneutics (2nd ed), The University of Chicago Press. p60 180 Triantafillou, P. (2012). New Forms of Governing. A Foucauldian Inspired Analysis, Palgrave Mcmillan. p11

181 Dreyfus, H. L. and P. Rabinow (1983). Michel Foucault. Beyond Structuralism and Hermeneutics (2nd ed), The University of Chicago Press. p61 and Triantafillou, P. (2012). New Forms of Governing. A Foucauldian Inspired Analysis, Palgrave Mcmillan. p12 182 Dreyfus, H. L. and P. Rabinow (1983). Michel Foucault. Beyond Structuralism and Hermeneutics (2nd ed), The University of Chicago Press. p66
} 
example, and one could argue that this would not have been possible if it were not for the increasing amount of discussion in Swedish research policy (among other places) about the role of universities in relation to innovation and economic growth.

Foucault's studies problematize rationality and subject formation and they identify boundaries, how categories are created and maintained. ${ }^{183}$ The possibility conditions as constructed in research policy during a particular decade open up for certain interpretations of development and the role of universities etc. and not others. The policies of the time and organizational structures form part of these possibility conditions. I can analyze how Sarec's policies set up and maintain certain boundaries and categories over time. The documents I have analyzed and the former directors I have interviewed can be conceptualized as discursive agents. According to policy researchers Karin Bäckstrand and Eva Lövbrand, ${ }^{184}$ discursive agents "interpret, articulate and reproduce storylines congruent with certain discourses." 185 These agents contribute to the strengthening, maintenance or weakening of central objects in the discourses identified.

Archaeology and genealogy are two alternative modes of writing history put forth by Foucault. 186 The archaeologist, he claims, is "interested in how one discourse formation comes to be substituted by another... it is not the purpose to discover the birth of discourses."187 At the same time he says that archaeology is pure description of discursive events and that the analysis of statements is a historical analysis which avoids all interpretation. ${ }^{188}$ This might be considered contradictory and problematic since it suggests that the historian can be completely objective. ${ }^{189}$ Archaeology, furthermore, assumes that discourses as autonomous practices produce the object of which it speaks more so than "non-discursive" factors. Discourse acts upon and changes non-discursive factors. ${ }^{190}$ Archaeology is more concerned with dominant discourses or serious claims to truth. ${ }^{191}$

The genealogist, on the other hand, studies how primary spaces emerge, spaces that "condition, limit and institutionalize" discursive formations. ${ }^{192}$ Genealogy

\footnotetext{
183 Ibid. pp174-175

${ }^{184}$ Building on the work of Hajer, M. (1995). The politics of environmental discourse: Ecological modernization and the policy process, Clarendon Press. and Litfin, K. (1994). Ozone Discourse: Science and Politics in Global Environmental Cooperation.

185 Bäckstrand, K. and E. Lövbrand (2007). Modernization and Civic Environmentalism. The Social Construction of Climate Change: Power, Knowledge, Norms, Discourses. M. E. Pettenger, Ashgate Publishing. p125

${ }^{186}$ Nilsson, R. (2006). Foucault - en introduktion, Egalité. pp58-59

187 Dreyfus, H. L. and P. Rabinow (1983). Michel Foucault. Beyond Structuralism and

Hermeneutics (2nd ed), The University of Chicago Press. pp73-44

188 Ibid., p50-51, builds on Foucault, M. (1972). The Archaeology of Knowledge \& the Discourse

on Language, Tavistock Publications. p109

$189 \mathrm{~A}$ critique which is also raised by Howarth (2000) on for example p62

190 Dreyfus, H. L. and P. Rabinow (1983). Michel Foucault. Beyond Structuralism and

Hermeneutics (2nd ed), The University of Chicago Press. pp61-62 and Howarth, D. (2000).

Discourse, Open University Press. pp52\&72

${ }^{191}$ Howarth, D. (2000). Discourse, Open University Press. pp54-55

192 Dreyfus, H. L. and P. Rabinow (1983). Michel Foucault. Beyond Structuralism and

Hermeneutics (2nd ed), The University of Chicago Press. pp106 \& 109
} 
does not study discourses in isolation, it produces a history which takes into account a diversity of elements which contribute to the constitution of knowledge - including nondiscursive practices. ${ }^{193}$ Foucault maintains that genealogy entails capturing the diversity of passing events, not force the telling of a balanced tale:

Genealogy does not pretend to go back in time to restore an unbroken continuity that operates beyond the dispersion of forgotten things; its duty is not to demonstrate that the past actively exists in the present, that it continues secretly to animate the present, having imposed a predetermined form on all its vicissitudes. ${ }^{194}$

In his genealogical studies, Foucault also engaged in a more critical evaluation of the discourses in question, 'genealogy is committed to a thoroughgoing 'perspectivism' in which events are perceived from the particular view of a 'situated' researcher." 195 I agree that it is impossible to restore a complete picture of history, but parts of the past can be traced in present policies; sometimes secretly animating it and sometimes explicitly. I see it as my duty in this case to explore and analyze such traces where they are visible.

Foucault maintains in his genealogical work that discursive formations need to be placed in a larger power context for us to be able to "evaluate its claim to describe reality." 196 In the Archeology of Knowledge, non-discursive factors are defined as including "an institutional field, a set of events, practices and political decisions, a sequence of economic processes that also involve demographic fluctuations, techniques of public assistance, manpower needs, different levels of employment etc." ${ }^{197}$ These are seen to surround and sustain the discursive factors, though discourse is still considered more constituting. He calls it a space or system of primary relations, which also relates to a space of reflexive or secondary relations, and a discursive system of relations. ${ }^{198}$ I interpret this as meaning that any given space consists of different sets of relations. The space might be "Swedish research aid" and the primary and secondary relations constitute what early Foucault might call the non-discursive aspects of this particular space - things such as the organization Sarec and its placement within the institution of Swedish aid etc.

Linguistics researcher Sara Mills maintains that although a political commitment is not as straightforward in Foucauldian discourse theory as it is when using for example ideology analysis, it is possible. ${ }^{199}$ Feminist and postcolonial analyses are a testament to this, states Mills, and other scholars like Peter Triantafillou maintain that Foucault's genealogy in particular contains potential for political critique in relation to for

\footnotetext{
${ }^{193}$ Howarth, D. (2000). Discourse, Open University Press. p72

${ }^{194}$ Foucault, M. (1977). Nietzsche, Genealogy, History. Language, Counter-Memory, Practice M.

Foucault, Basil Blackwell. p146

195 Howarth, D. (2000). Discourse, Open University Press. p71

${ }^{196}$ See Dreyfus, H. L. and P. Rabinow (1983). Michel Foucault. Beyond Structuralism and

Hermeneutics (2nd ed), The University of Chicago Press. p72

197 Ibid. p157

198 Ibid. p63

199 Mills, S. (2003). Discourse, Routledge. p29
} 
example forms of governance. We can be considered "trapped" in our time, entrenched in a specific historical perspective on what kind of political action/government seems reasonable for instance, within which it is very difficult to imagine other perspectives. ${ }^{200}$ Foucault's analyses are envisaged to contribute to "unsettling existing power relations, making them more mobile and reversible, and by implication creating more space for the exercise of freedom."201

This study could be classified as a genealogy in the sense that I am not simply describing the discourses (nor claiming that I can), and the discourses are studied in relation to their context. The purpose is to capture dominant discourses as well as irregularities and continuities that do not necessarily fit the more general categories.

\section{Fairclough's take on discourse}

I have chosen to complement the perspectives of Foucault discussed above with certain parts of Fairclough's critical discourse analysis (CDA) approach. ${ }^{202}$ I consider his conception of discourse useful and therefor helpful in guiding the analysis.

According to Fairclough, "discourses are semiotic ways of construing [representing] aspects of the world (physical, social or mental) which can generally be identified with different positions or perspectives of different groups and social actors."203 Discourse encompasses both written and spoken language, including visual images. ${ }^{204}$ Fairclough regards language use as "a form of social practice rather than a purely individual activity or a reflex of situational variables," 205 it is not just something which represents the world - it also signifies or constitutes it. "Different discourses constitute key entities in different ways, and position people in different ways." 206

In Fairclough's view there is a context surrounding the discursive (similar to what Foucault calls non-discursive practices) which is significant for how things develop and change. The structure of the political system is one such example. "Reality (the potential, the actual) cannot be reduced to our knowledge of reality, which is contingent, shifting and partial." 207 He draws a parallel to the texts we analyze, saying that the potential realities or meanings of a text cannot be exhausted by our knowledge of them. In relation to constructivism he maintains that the way we represent the social world can change its construction but that this also depends on many contextual factors. ${ }^{208}$

\footnotetext{
200 Triantafillou, P. (2012). New Forms of Governing. A Foucauldian Inspired Analysis, Palgrave Mcmillan. pp1, 4-5

201 Ibid. p2

${ }^{202}$ Fairclough is the name most frequently associated with CDA, though there are other variants of the school, Such as the work by Teun A. van Dijk and some of the work by Ruth Wodak ${ }^{203}$ Wodak, R. and M. Meyer (2009). Methods of Critical Discourse Analysis (2nd ed), Sage publications. p164

${ }^{204}$ Fairclough, N. (1993). Discourse and Social Change, Polity Press. p3

205 Ibid. p62

206 Ibid. pp3-4

${ }^{207}$ Fairclough, N. (2003). Analysing Discourse - Textual Analysis for Social Research, Routledge. p14

208 Ibid. pp8-9
} 
In line with Bourdieu, Fairclough is in favour of a "constructivist structuralism... a way of seeing and researching social life as both constrained by social structures, and an active process of production which transforms social structures".209 Discourse is both constituted and constitutive, but is only one of many aspects of any social practice. Furthermore, discursive practices are interdependent, "any discourse practice is generated out of combinations of others and defined by its relationship to others." 210 What is said and what is written can be interpreted very differently depending on which discursive formation it is said or written within.

Fairclough uses the discourse concept in different ways. One level is abstract, where language use is seen can be a social practice (relating to a wider context, like Swedish state politics). Discourse can also be a certain type of language used within a specific setting or context, such as foreign aid, marketing or banking. A slightly more concrete use of the concept is "a way of speaking which gives meaning to experiences from a particular perspective which can be distinguished from others." ${ }^{211}$ An example of this might be feminist discourse or liberal discourse, although categories can be even more specific of course. Discourses can be constructive in several ways, they can construct: social identities and subject positions (identity function), relationships between people (relational function), and systems of knowledge and belief (ideational function). ${ }^{212}$

...texts simultaneously represent aspects of the world (the physical world, the social world, the mental world); enact social relations between participants in social events and connect parts of texts together, and connect texts with their situational contexts. ${ }^{213}$

Fairclough calls every instance of language use a communicative event which has three dimensions; it is a text, a discursive practice and a social practice. ${ }^{214}$ The analysis of discourse should therefore take into account the context in which the text in question (spoken, written or visual) is produced and consumed.

A three-dimensional model is proposed by Fairclough to conceptualize discourse. I have redrawn it below, with attempts to frame my own case to the right. $\mathrm{He}$ aimed to bring different traditions together in this model, linguistics and macrosociological theory for example.215

\footnotetext{
${ }^{209}$ Chouliaraki, L. and N. Fairclough (1999). Discourse in Late Modernity. Rethinking Critical Discourse Analysis, Edinburgh University Press. p1

${ }^{210}$ Fairclough, N. (1993). Discourse and Social Change, Polity Press. pp39-40

${ }^{211}$ Jörgensen, M. and L. Phillips (2002). Discourse Analysis as Theory and Method, Sage publications. p66-67

212 Fairclough, N. (1993). Discourse and Social Change, Polity Press. p64

${ }^{213}$ Fairclough, N. (2003). Analysing Discourse - Textual Analysis for Social Research, Routledge. pp26-27

${ }^{214}$ Jörgensen, M. and L. Phillips (2002). Discourse Analysis as Theory and Method, Sage publications. p68

215 See for example Fairclough, N. (1993). Discourse and Social Change, Polity Press. pp70-73
} 
DISCURSIVE PRACTICE The research aid organization (Sarec) Processes relating to text production and consumption

TEXT

Official policy documents and interviews Communicative events. Written and spoken language, images.

Figure 2: Fairclough's three-dimensional model

The discursive practice is where the production, distribution and consumption of texts occur. Who does what? Where and under what conditions? How are texts distributed, who reads them, why and how? Depending on if we are talking about a newspaper, an academic article, a photo, a commercial ad, an interview transcript or an annual report, these routines and conditions vary. ${ }^{216}$ These processes of production and interpretation are influenced and conditioned by the structures, norms and convention of its context, including the social structures. ${ }^{217}$

The social practice dimension is a wider context and can contain many different economic, political or cultural elements for example - all of which can be discursive to some extent. ${ }^{218}$ Ideologies are embedded in discursive practices, Fairclough maintains. They assist in establishing or maintaining "relations of domination" or hegemony, ${ }^{219}$ but they can also be used in struggles to reshape and transform discursive practices. Texts may have remnants and traces of these ideologies but ideologies do not reside in texts, argues Fairclough. Meaning is produced through the social process of interpretation which can lead to quite different results depending on how it is done. ${ }^{220}$

Studying the discursive practice entails focusing on how for example authors draw upon previous discourses or how readers interpret texts, while the study of the texts

\footnotetext{
216 Ibid. pp78-79

217 Ibid. p80

218 Ibid. p66

219 Fairclough builds on Gramsci, A. (1971). Selections from the Prison Notebooks, International Publishers., and maintains that "hegemony is leadership as much as domination across the economic, political, cultural and ideological domains of a society... [...] it is the power over society as a whole of one of the fundamental economically-defined classes in alliance with other social forces, but it is never achieved more than partially and temporarily, as an 'unstable equilibrium'. Hegemony is about constructing alliances, and integrating rather than simply dominating subordinating classes, through concessions or through ideological means, to win their consent." Fairclough, N. (1993). Discourse and Social Change, Polity Press. p92 ${ }^{220}$ Fairclough, N. (1993). Discourse and Social Change, Polity Press. pp87-89
} 
themselves is more focused on formal features like vocabulary use.221 Fairclough maintains that the researcher needs other theories in order to analyze the social practice dimension, such as macro and middle-range theories about how society is constituted and changes. ${ }^{222}$ Individual text may draw on discourse elements from other texts (intertextuality ${ }^{223}$ ), and change can be analyzed through investigating intertextuality. ${ }^{224}$

My research questions encompass all of these levels - research aid policy contains ideas regarding researcher identities for example, relationships between them, and their relation to a larger system of knowledge and belief about the role of science and technology in development. The study focuses primarily on texts, but the analysis is also consistently related to the contexts which presumably affect, and are affected by, these texts.

The analysis relates more to the wider social practice than to the more immediate discursive practice. To be more specific, the analysis of the production and interpretation of the texts by others/intended audiences is the least studied aspect. Having said that, some of this interpretation does become visible. The analysis of evaluations and the responses coupled to them is one such place where one type of interpretation by others is illustrated. Also, some interviews and annual reports at times refer to how $\mathrm{X}$ report was received and interpreted by actor $\mathrm{Y}$ for example, but I did not set out to systematically investigate how intended readers interpreted central texts.

\section{Discourses and imaginaries}

Another key concept to address in this context is imaginaries. The concept is used by Fairclough, ${ }^{225}$ who maintains that discourses contain both representations of how things are and have been as well as imaginaries of "how things might or could or should be"; future visions which can put into effect through networks of practices. ${ }^{226}$ Imaginaries, in this sense, are the part of discourses that refer to things like goals and visions.

The knowledges of the knowledge-economy and knowledge society are imaginaries in this sense - projections of possible states of affairs, 'possible worlds'. These

\footnotetext{
221 Jörgensen, M. and L. Phillips (2002). Discourse Analysis as Theory and Method, Sage publications. p69

222 See for example Wodak, R. and M. Meyer (2009). Methods of Critical Discourse Analysis (2nd ed), Sage publications. pp168-169

${ }^{223}$ Where a distinction can be made between manifest and constitutive intertextuality/interdiscursivity, the former being more explicit Fairclough, N. (1993). Discourse and Social Change, Polity Press. p85

${ }^{224}$ Jörgensen, M. and L. Phillips (2002). Discourse Analysis as Theory and Method, Sage publications. p73

225 Though one its first proponents was Jacques Lacan, and many others have used the concept in different variations since. See for example Strauss, C. (2006). "The Imaginary." Anthropological Theory 6(3): 322-344 , Taylor, C. (2004). Modern Social Imaginaries, Duke University Press, Strauss, C. (2006). "The Imaginary." Anthropological Theory 6(3): 322-344 Marcus, G. (1995). Technoscientific Imaginaries: Conversations, Profiles, and Memoirs, University of Chicago Press. 226 Fairclough, N. (2010). Critical Discourse Analysis - The Critical Study of Language (2nd ed), Longman. p266
} 
imaginaries may be enacted as actual (networks of) practices - imagined activities, subjects, social relations etc. Such enactments include materialisations of discourses, in the 'hardware' (plant, machinery, etc) and the 'software' (management systems etc.) ${ }^{227}$

Another use of the concept is sociotechnical imaginaries, which STS researchers Sheila Jasanoff and Sang-Hyun Kim define as: "collectively imagined forms of social life and social order reflected in the design and fulfilment of nation-specific scientific and/or technological projects." 228 The role of the state and non-scientific political institutions in defining the purpose of publically supported science and technology deserves more attention in STS research, according to Jasanoff and Kim. In their 2009 article about national policy narratives of the US and South Korea about nuclear power, they question who's interests are served, how the public good is defined and steered and how technological risks are handled. ${ }^{229}$ How are controversies solved, and how do science and technology projects reinforce particular conceptions of nationhood and the good society?

Sociotechnical imaginaries, they maintain, are not policy agendas: "they reside in the reservoir of norms and discourses, metaphors and cultural meanings on which actors build their policy preferences." ${ }^{230}$ In a manner similar to discourses, sociotechnical imaginaries create certain possibility conditions, building on the idea that the collective imagination can be constitutive of social and political development. They construct possible futures. ${ }^{231}$ Sociotechnical imaginaries are active exercises of state power that help create the political will or resolve to attain certain kinds of developments through the application of science and technology. ${ }^{232}$ Exploration of past sociotechnical imaginaries can provide useful insights for present developments. In a later article on the same kind of topic, for instance, they conclude that South Korea's national energy policies show how the risks associated with energy technologies are considered far less important than the potential failure to develop as a country. ${ }^{233}$

The concept has been used in slightly different ways to study areas like energy politics ${ }^{234}$, neuroscience ${ }^{235}$, nanotechnology ${ }^{236}$ and development. In a study of the Rockefeller foundation for example, Elta Smith uses the term imaginaries to study the

\footnotetext{
227 Ibid. p266

${ }^{228}$ Jasanoff, S. and S.-H. Kim (2009). "Containing the Atom: Sociotechnical Imaginaries and Nuclear Power in the United States and South Korea." Minerva 47(2): 119-146. p120

229 Ibid. p120

230 Ibid. p123

${ }^{231}$ Ibid. p122

232 Ibid. p123

${ }^{233}$ Jasanoff, S. and K.-S. Kim (2013). "Sociotechnical Imaginaries and National Energy Policies." Science as Culture 22(2): 189-196. P189

${ }^{234}$ Levidow, L. and T. Papaioannou (2013). "State imaginaries of the public good: shaping UK innovation priorities for bioenergy." Environmental Science and Policy 30: 36-49.

235 Pickersgill, M. (2011). "Connecting neuroscience and law: anticipatory discourse and the role of sociotechnical imaginaries." New Genetics and Society 30(1): 27-40.

${ }^{236}$ Felt, U. (2013). Keeping Technologies Out: Sociotechnical imaginaries and the formation of a national technopolitical identity. Pre-Print, University of Vienna.
} 
ideas about how agricultural research projects generate development. ${ }^{237}$ She defines imaginaries as:

\begin{abstract}
...a particular, often complex view of the world that comes to shape agendas, research trajectories, projects and policies. [...] They are normatively loaded visions not only of what should be done "in the world" but also how it should be undertaken and why. Imaginaries of development are comprised of science and technology imperatives as well as economic, political and cultural, and are hence sociotechnical. ${ }^{238}$
\end{abstract}

The concept of sociotechnical imaginaries refers specifically to the role of science and technology and I consider it to be a complementary concept to discourse in the framing and analysis of research aid policy. My goal has been to identify at least one major sociotechnical imaginary in each decade as a way to understand what kind of futures the discourses are enabling. Sociotechnical imaginaries can also be useful in a critical discussion of alternative futures.

\title{
Taking a critical post-structuralist stance
}

If everything is dependent on how we interpret it through our language and conceptions, can we really call anything non-discursive? This is an example of where the structuralist versus post-structuralist question enters; it entails potentially different ontological positions and thus affects what one considers relevant material to study for example, and also what can reasonably be concluded from it.

One common critique of social constructivist theory and much of discourse theory is that it is "too relativist." Here I agree with Jörgensen and Phillips when they say that knowledge and identities can be contingent in principle - but quite inflexible in specific situations. ${ }^{239}$ "Situations place restrictions on the identities which an individual can assume and the statements which can be accepted as meaningful." 240 Situations are always conditioned by elements such as the people present, what they say and do, relations between them and their material surrounding. ${ }^{241}$

The significance of this in relation to my study regards the challenge of where to draw the line concerning the context of the object studied. I consider some historical contextualization of each decade necessary to help frame the analysis of the annual

\footnotetext{
${ }^{237}$ Smith, E. (2009). "Imaginaries of Development: The Rockefeller Foundation and Rice Research." Science as Culture 18(4): 461-482.

${ }^{238}$ Ibid. p462. Smith's definition is inspired by Taylor, C. (2004). Modern Social Imaginaries, Duke University Press., Andersson, B. (1991). Imagined Communities: Reflections on the Origin and Spread of Nationalism, Verso books., Appadurai, A. (1996). Modernity at large - cultural dimensions of globalization, University of Minneapolis Press., and Jasanoff, S. (2006). States of Knowledge: The Co-production of Science and the Social Order, Routledge.

${ }^{239}$ Jörgensen, M. and L. Phillips (2002). Discourse Analysis as Theory and Method, Sage publications. p6

240 Ibid. p8

${ }^{241}$ Fairclough, N. (2003). Analysing Discourse - Textual Analysis for Social Research, Routledge. p25
} 
reports and other material. In relation to the study object, then, certain surrounding preconditions become relevant context. This is something which is also discussed by Jörgensen and Phillips as they critique the difficulty of drawing the boundaries between the levels empirically; one can solve the issue by treating it as an analytical distinction. ${ }^{242}$ Hence, not everyone would necessarily agree that the "social practice" in this case is Swedish aid politics, but it is up to me to provide good reasons for doing so and this in turn has to do with what kind of purpose I have and which field I am in.

In other words, whether or not one wants to call these contextual factors or elements non-discursive does not need to be of great consequence. Jörgensen's and Phillip's example about flooding is a useful way to illustrate the relationship between "reality" or "material facts" and our interpretation of them. Rivers can flood and people can drown if they are at the wrong place at the wrong time, but how people make sense of and relate to the phenomenon of flooding varies immensely. It means different things to different people in different situations. The way a person relates to and talks about a particular flood depends on many things, for example how the flood affected them (was it just observed from a comfortable distance or was their own house flooded?) religious views, age, and whom the person is talking with. There are also a number of interpretations that are more likely in any given time and place. It might be reasonable in some contexts to interpret flooding as being the result of heavy rain upstream, or melting of glaciers, but some may instead see it as god's punishment for sins committed this year or as a blessing for the land. The interpretations represent different rationalities, and when certain discourses are dominant, alternative interpretations might not be understood or considered valid.

A dualistic perspective has dominated the debate about approaches and methods in social science according to Berth Danemark et al (2002); positivism versus hermeneutics, universalism versus particularism or modernism versus postmodernism. They present critical realism as positioning itself somewhere in the middle, without necessary being an outright "mix." 243 I consider my positioning on this scale as critically post-structuralist. On that note, one might object to the combination of Foucault and Fairclough with reference to them possibly being ontologically incompatible; Fairclough gives more agency to the physical and material, whereas Foucault's post-structuralist position might grant discourse more agency than so-called "non-discursive elements".244 To that I would say that while Foucault was mainly considered a poststructuralist, he resisted being labelled, and his stance on the relationship between discursive and nondiscursive elements changed over time, as shown above. As for Fairclough, while he builds his ideas on realist ontology, he states that objects do not exist independent of our reference to them. That does not equal an incompatibility in my view.

\footnotetext{
${ }^{242}$ Jörgensen, M. and L. Phillips (2002). Discourse Analysis as Theory and Method, Sage publications. pp89-90

243 Danemark, B., M. Ekström, et al. (2002). Explaining Society: Critical Realism in the Social Sciences, The Cromwell press. p2

244 Jörgensen, M. and L. Phillips (2002). Discourse Analysis as Theory and Method, Sage publications. p20
} 
International relations researcher Jan Selby claims that the use of Foucault in theorizing international and world politics would be more effective if combined with perspectives that recognize structural dimensions of power. ${ }^{245}$ Selby maintains that Foucault's ideas could be combined with Marxist perspectives, they are not as incompatible as often claimed:

...both the Marxist tradition and Foucault share a sensitivity to historical disjunctures and transformations, and a corollary hostility to ahistorical and positivist modes of analysis, which set them apart from orthodox IR and its erroneous universalization of modern politics. [...] both Marx and Foucault were interrogators of bourgeois capitalist society, and of liberal doctrines of the sovereignty and freedom of the individual. [...] both Marx and Foucault outline (equally underdeveloped) non-statist models of the state...246

Another objection to the combination of Foucault and Fairclough may be that they conduct different kinds of critique. I take the concept of critical in this setting to mean that the research is not viewed as neutral, it entails a political commitment to social change. The research in question should aim to counteract inequality in some way. Fairclough argues that discourse functions ideologically and creates subjects based on categories such as gender or class for example (identity function), contributing to the reproduction or transformation of dominant relations. Foucault's kind of critique is considered less direct. Philosopher Colin Koopman maintains that Foucault engaged in "critical problematization" which lends itself to normative commitments but not necessarily explicit critique with the goal to undermine and subvert or strengthen different practices. $^{247}$ These differences to me do not signal incompatibility either. I align myself with the position of education researcher Linda Graham:

...the Foucauldian discourse analyst certainly shares the critical discourse analyst's concern as to the 'relationship of language to other social processes, and of how language works within power relations' (Taylor, 2004:436). Whilst these two approaches may offer different analyses, this simply confirms the assertion that 'there will always be other perspectives from which to interpret the material under review' (Humes and Bryce, 2003:180) and the kaleidoscopic nature of language and meaning; certainly not that one analyses is any more 'true' than the other. ${ }^{248}$

The type of critique I deliver in this study could be placed closer to what Koopman describes above as critical problematization, I do not suggest concrete policy changes as part of my conclusions for example. I do not, however, see Fairclough's commitment to

245 Selby, J. (2007). "Engaging Foucault: Discourse, Liberal Governance and the Limits of Foucauldian IR." International Relations 21(3): 324-345. pp325-326

246 Ibid. p340

247 Koopman, C. (2009). Two uses of genealogy: Michel Foucault and Bernard Williams.

Foucault's Legacy. C. G. Prado, Continuum International Publishing. pp91-92

248 Graham, L. J. (2005). Discourse analysis and the critical use of Foucault. Australian Association for Research in Education. Sydney. p5 
social change as being a significantly different endeavor than the problematization that Foucault engaged in.

\section{Science and Technology Studies and colonialism(s)}

...the shift from colonial to postcolonial science has meant very little in terms of the capacity to use the tools of research to shape economic development. Most newly decolonized states invested heavily in education, and especially in the training of scientists and technicians. However, their reliance on import substitution schemes for the transfer of industrial technology provided few opportunities for local technicians to innovate in the application of science. [...] globalization has created a situation in which, despite the rhetoric of national sovereignty, most developing countries remain in a condition of dependency. ${ }^{249}$

A central issue in this study, as well as in Science and Technology Studies, is the relationship between science, technology and ideas about development and modernity. STS is an interdisciplinary field covering a vast amount of subjects and perspectives today, but a common denominator is the study of the social process and political effects of science and technology. ${ }^{250}$ The field became more widely known in the late 1970's and 1980s for its studies of technology, laboratory work and scientific controversies. It was "a philosophically radical project of understanding social issues linked to science and technology as discursive, social and material activities [...] and how these developments could be harnessed to democratic and egalitarian needs." 251

So how can perspectives and experiences from STS assist in the analysis of research aid discourse? I argue that it does so in several ways, for example; by questioning the objectivity and universality of "Western" science, by challenging conceptions of modernity, critically analyzing the interplay between politics and science and technology, and not least by providing a cross-disciplinary platform from which to do so. The STS literature contributes to a nuanced discussion about the discourses identified in the texts.

Science and technology have been used to legitimate imperialism and colonialism, also making STS perspectives a fruitful toolbox to use in studies related to development, though it has been relatively marginal as an area of STS research. ${ }^{252}$ Efforts to integrate postcolonial perspectives and create meeting points and collaboration between for example Development Studies and STS have increased in the recent decade 253 ,

\footnotetext{
249 Merson, J. (2000). "Bio-prospecting or Bio-piracy: Intellectual Property Rights and Biodiversity in a Colonial and Postcolonial Context." Osiris 15(282-296). pp283-284 ${ }^{250}$ Sismondo, S. (2010). An Introduction to Science and Technology Studies (2nd ed), WileyBlackwell. preface

251 Ibid. preface

252 Ibid. pp195-196

${ }^{253}$ More development-related sessions appear in STS conferences and the number of papers relating to the topic has grown. See for example Warwick Anderson $(2002,2005,2009)$, Sandra Harding $(1999,2008,2012)$, Maureen McNeil (2005), Wesley Shrum $(1995,2005,2007)$, Kavita Philip (2008, 2012), Suzan Cozzens (2007, 2009), Michael Mascarenhas (2003, 2012), Wenda K. Bauchspies $(2005,2012)$, Ruha Benjamin $(2009,2012)$, Suzanne Moon $(2004,2005,2010)$, Amit
} 
and a niche has developed which is sometimes referred to as postcolonial technoscience, postcolonial science studies or studies of global science but the topics relating to development and/or postcolonialism are diverse and found under many different STS spaces. The "political economies of knowledge" has grown as an area of study, for example, focusing on how different actors try to influence and manage the flow of knowledge and technology more efficiently - its production, distribution and consumption. ${ }^{254}$ Issues of concern are for example the commercialization of science and global scientific relations. ${ }^{255}$ Before taking on some of the development-related theorizing within STS, I will discuss some ideas and concepts from postcolonial studies which inform both STS and my study.

The academic field of postcolonial studies is a very diverse one ${ }^{256}$, and has a rich and complex history which I will not fully account for here. A relevant place to start is in a definition of central concepts. Postcolonialism, argues postcolonial researcher Ania Loomba, refers to a highly variable relationship of inequity (in a similar way to the concept patriarchy). It should be used with caution and qualification since it is a generalization; postcoloniality is "articulated alongside other economic, social, cultural and historical factors, and therefore in practice, it works quite differently in various parts of the world". 257

Colonialism can be defined as "the conquest and control of other people's land and goods." 258 One can distinguish between different stages and categories of colonialism depending on which periods of history are being discussed for example, but a central aspect of colonialism was the flow of profits back to the "mother-country". ${ }^{259}$ The role of capitalism in colonialism can be theorized in many different ways and imperialism has sometimes been used to refer to the more economic forms of domination, where direct political rule of territories is not a necessary part. Neocolonialism is sometimes used in a similar manner, as will also be discussed in chapter four on previous research. ${ }^{260}$ The differences between political and economic control and influence in these conceptualizations are far from clear, however, and an important reason for why it is important to be cautious in using them. ${ }^{261}$

Loomba maintains that though colonial discourse studies are in debt to Foucault, ${ }^{262}$ Foucault's theories were criticized for being inadequate for postcolonial

Prasad (2008), Chris J. Shepherd (2005, 2006), Rob Hagendijk (2008, 2012), Richard Rottenburg $(2009,2012)$ and Edward Woodhouse $(2002,2007)$ to name a few.

254 Sismondo, S. (2010). An Introduction to Science and Technology Studies (2nd ed), Wiley-

Blackwell. p189

255 Ibid. pp189-191

${ }^{256}$ See for example Loomba, A. (2005). Colonialism/Postcolonialism. The New Critical Idiom

(2nd ed), Routledge. pp2-4

${ }^{257}$ Ibid. p22

258 Ibid. p8

259 Ibid. pp9-10

260 Ibid. pp10-11

261 Ibid. pp11-12

262 With reference to for example Said, E. W. (1978). Orientalism, Vintage books. 
analysis since they are Eurocentric in their conceptions. ${ }^{263}$ This critique, though no doubt valid, does not necessarily undermine the usefulness of discourse theory in the study of science and technology policy. ${ }^{264}$ Though I am not studying low-income countries per se, it is important to reflect upon the potential consequences of certain assumptions or concepts: “...far from being an objective, ideology-free domain, modern Western science was deeply implicated in the construction of racist ways of thinking of human beings and the differences between them." 265

The way the colonialism-concept is used in this study is based on the idea that despite the end of formal colonialism, and despite a more diversified development map, high-income countries have to a large degree continued to influence and/or dominate many areas through pervasive economic and technological systems. It is a process that is still on-going, albeit in different and less formal forms. Countries with high levels of resources and capacity now have the upper hand through for example economic, scientific, and technological means instead of having direct political or geographic control. ${ }^{266}$ While the concept of postcolonial will appear on account of its widespread use in the literature, I prefer the term neocolonial since it distinguishes itself from formal state colonialism. It is also more specific than postcolonial in the sense that is underlines both the continuity of certain power relations as well the potential to "invent" new ways of controlling or influencing the way things proceed in countries. ${ }^{267}$

STS researcher Kumju Hwang (inspired by Schott and Traweek ${ }^{268}$ ) re-enacts the colonialist discourse of center and periphery in order to understand the unequal relationship between low- and high-income countries when it comes to international relations in science and technology. Hwang maintains that core-periphery relationships have shaped the practices and identities of science and researchers:

...the means of reenactment have not been direct violence and political force but the interactions between scientific actors and communities' self-referential systems, infrastructures, reputations, recognition, nationalities, political and scientific heritage, and so forth. The re-enactment of colonialist discourse contains the fundamental notion that sociocultural elements [...] predetermine the status of an

\footnotetext{
${ }^{263}$ Loomba, A. (2005). Colonialism/Postcolonialism. The New Critical Idiom (2nd ed), Routledge. pp49-50

264 See for example Cornwall, A. (2007). "Buzzwords and fuzzwords: deconstructing development discourse." Development in Practice Vol 17:4(4): 471-484

265 Loomba, A. (2005). Colonialism/Postcolonialism. The New Critical Idiom (2nd ed), Routledge. p56

266 See for example Shaobo, X. (1997). "Rethinking the Problem of Postcolonialism." New

Literary History 28(1): 7-19.

${ }^{267}$ In line with for example Shaobo (1997) and Loomba (2005)

268 Schott, T. (1998). "Ties between center and periphery in the scientific world system:

Accumulation of rewards, dominance and self-reliance in the center." Journal of World Systems Research 4(2): 112-144. and Traweek, S. (1988). Beamtimes and lifetimes: The world of high energy physicists, Harvard University Press.
} 
individual scientist or engineer, or an individual institution that stands in the core or periphery in the hierarchical structure of international relations. ${ }^{269}$

The center (which during the $20^{\text {th }}$ century was the US first and foremost, but also Western Europe) has stronger capacity, and attracts both students and scientists from all over the world. Hwang argues that due to this global inequality, peripheral science is often associated with low production of knowledge, it adapts knowledge from elsewhere to local contexts, and when it does produce knowledge, it may be assumed to be of lower status. ${ }^{270}$ Hwang argues that the picture is more complex than this, however, and suggests that a "globalization of science and technology" theoretical approach is more adequate. ${ }^{271}$ The article builds on a study of Korea and among other things, Hwang asks why unequal parties collaborate. One conclusion is that the primary purpose of cooperation is not knowledge production; collaboration benefits knowledge transfer, career-building, model application to local conditions, or fund-raising. ${ }^{272}$ In other words, the creation of new knowledge alone is not the reason for collaboration, there are other reasons like those explored in my study, such as capacity building and application of international research to local conditions (agricultural or medical research for example).

Sismondo and Goonatilake, argue along similar lines as Hwang, and underline the fact that the scientific resources in the world are unequally distributed, also using terminology associated with dependency theory:

\begin{abstract}
Despite sizeable numbers of scientists, the less developed world remains scientifically peripheral; it is "dependent" science: "What is considered scientific knowledge in a dependent context is only that which has been made legitimate in the centre. It is then imitated in the periphery through the operation of pervasive dependent social and cultural mechanisms...The fundamental and the basic core knowledge grows largely in the West and is transferred to developing countries in the context of a dependent intellectual relationship."273
\end{abstract}

It is rather sweeping to say that all science in low-income countries is dependent and peripheral, but they nevertheless make the point that Western science remains dominant and consider this problematic. Interactions between people in peripheral and central places are affected by the fact the central "expertise" is privileged. ${ }^{274}$ While Sismondo and others maintain that STS has been good at displaying the locality of science and

\footnotetext{
${ }^{269}$ Hwang, K. (2008). "International Collaboration in Multilayered Center-Periphery in the Globalization of Science and Technology." Science Technology Human Values 33(1): 101-133. pp104-105

270 Ibid. pp105-106

271 Ibid. pp108-109

272 Ibid. pp120-123

${ }^{273}$ Sismondo, S. (2010). An Introduction to Science and Technology Studies (2nd ed), WileyBlackwell. p201, citing Goonatilake, S. (1993). Modern Science and the Periphery. The "Racial" Economy of Science. S. Harding, The University of Indiana Press: 259-267. p260 274 Sismondo, S. (2010). An Introduction to Science and Technology Studies (2nd ed), WileyBlackwell. p201
} 
technology, they claim that its' success in analyzing conflicts has stood in the way of offering positive lessons for development. ${ }^{275}$

The increasing commodification of science globally 276 is one of the reasons why it is of importance to conduct more postcolonial studies of science and technology, according to Anderson, who has published several articles on the topic. ${ }^{277}$ He maintains that a postcolonial analysis "offers us a chance of disconcerting conventional accounts of so-called 'global' technoscience, revealing and complicating the durable dichotomies, produced under colonial regimes, which underpin many of its practices and hegemonic claims." ${ }^{278}$ STS research, he maintains, has come to study traditionally postcolonial issues from globalization perspectives, which he considers less critical than postcolonial genealogies for instance. ${ }^{279}$ Anderson's reasoning above is in line with the type of explicit critical stance that Fairclough calls for.

An STS scholar who has written extensively about the issue of inequalities and science and technology is Sandra Harding. ${ }^{280}$ One of her books, Sciences from Below (2008), asks whether Western modernity and its institutions (including science) has the capacity to deliver social progress given that this concept of modernity embraces a certain type of development driven by an objective scientific rationality which tends to crowd out "others", that is, women in general and non-Western men. ${ }^{281}$ She is critical of how modernity is used not least since it is often contrasted with traditional, a binary which continues to be influential in science and science policies and which tends to label the interests of traditional people and women as irrational and/or irrelevant. ${ }^{282}$ Harding claims that:

...this binary needs examination because modern discourses are haunted by specters of the feminine and the primitive. Objectivity, rationality, good method and other self-proclaimed modern achievements are all measured in terms of their distance from whatever is associated with the feminine and the primitive. ${ }^{283}$

\footnotetext{
275 Such as Sismondo (2010), Cozzens et al $(2007,2008)$ and Prasad (2008)

276 associated with discussions about Mode 2 science for example

277 Andersson, W. (2002). "Introduction: Postcolonial Technoscience." Social Studies of Science 32(5-6): 643-658. p644

278 Ibid.

${ }^{279}$ Andersson, W. (2009). "From subjugated knowledge to conjugated subjects: science and globalization, or postcolonial studies of science?" Postcolonial Studies: culture, politics, economy 12(4): 389-400. pp389 \& 396-398

280 In books like Harding, S. (1998). Is Science Multicultural? Postcolonialisms, Feminisms and Epistemologie, Indiana University Press. and Harding, S. (1999). The Racial Economy of Science: Toward a Democratic Future Indiana University Press.

281 Harding, S. (2008). Sciences from Below- Feminisms, Postcolonialisms, and Modernities, Duke University Press. pp1-2

282 Ibid. p3

${ }^{283}$ Ibid. p3
} 
She maintains that this needs to be questioned and multiple modernities need to be acknowledged - being "Western" is not the only way to be modern. ${ }^{284}$ In order to make sciences more inclusive and democratic, Western researchers must consider feminist and postcolonial science studies insights. At the same time, analyses of modernity "from above" do not gain enough legitimacy. According to Harding's standpoint epistemology, such a project necessitates capturing the view of the least advantaged groups, hence her purpose is to facilitate views of modernity and its sciences "from below." 285 Harding asks STS scholars to step up their level of controversiality by questioning the modernity/tradition binary more extensively. ${ }^{286}$ As STS scholars we should engage in developing progressive anti-colonialist and anti-sexist expertise in our teaching and writing, always keeping in mind the daily lives of the people who have benefited the least from "modernity."287

While I find her account and critique of racism and sexism in the history/present of Western science very useful, there are many centers and peripheries in the world, including within countries. Furthermore, there are not just rich and poor countries but a very large group in-between. Whether or not one takes this diversity as a point of departure, I would say, has consequences for how one might frame analyses in research. I strongly agree with Harding in that we should be critical of inequalities and act to lessen them, but a researcher from a so-called low-income country is not necessarily a "disadvantaged" voice and "Western" researchers should not be assumed incapable of thinking outside the privileged box. ${ }^{288}$

Science and technology for development is studied in different ways within STS, one example being the EU research project ResIST (Researching inequality through science and technology), led by the James Martin Institute at Oxford. ${ }^{289}$ Different "work packages," research questions and parts of the world were handled by different universities. The objective of the project was to understand how science and technology could both increase and mitigate inequalities. ${ }^{290}$ One of the results of the project was a model of how science and technology consisting of three types of inequalities. Cozzens et al maintain that structural inequalities are due to unequal distribution of capacities, and that representational inequality entails underrepresentation in political, economic and

\footnotetext{
${ }^{284}$ Ibid. p3

285 Ibid. p5

286 Ibid. pp7-8

287 Ibid. pp223-226

${ }^{288}$ Anderson (2009) expresses similar criticism, stating that her conceptualizations of Western and other sciences are "abstract and essentialized", and that she does not engage enough with "conventional postcolonial critique", p393

${ }^{289}$ Collaborating partners in the project were Germany (ISI FhG, Karlsruhe), Malta (University of Malta), Mozambique (Eduardo Mondlane University, Maputo), the Netherlands (University of Amsterdam), Norway (NIFU-STEP, Oslo), Portugal (CES, University of Coimbra), South Africa (CREST, Stellenbosch University), Turkey (Ankara Branch of the Middle East Technical University), the United Kingdom (Universities of Oxford and Leeds) and the United States (Georgia Institute of Technology)

290 ResIST. (2006). "Researching inequality through science and technology." Retrieved 110713, from http://www.resist-research.net/home.aspx. where all the projects reports can be found.
} 
cultural activities. The latter affects whose interests are represented in proposed solutions to political problems for example. Together, "structural and representational factors produce inequalities in effects, that is, in the distribution of benefits and costs for various individuals and households." 291 Another conclusion put forth by the research team on the basis of various country studies was that a so-called "social cohesion agenda" should be expanded in science, technology and innovation policies. Social cohesion entails a focus on reducing inequalities to spread the benefits and costs of science and technology more evenly. 292

One could say that Harding, Andersson, Sismondo, Cozzens, Hagendijk, Healey, and many others whom I do not have space to discuss here, in different ways challenge researchers (as well as other actors) to become more explicitly anti-colonialist or decolonizing. One way to do this, I maintain, is to critically analyze the sociotechnical imaginaries of actors that in different ways affect low-income country policy on science and technology. It also entails being mindful of the theories and methods we use, the categories we construct and whom we might benefit through our research. ${ }^{293}$

\section{Boundary organizations - enabling science for development?}

The fact that organizations such as Sarec are influenced by both aid politics and research politics makes an analysis of their discourses and sociotechnical imaginaries a very interesting and complex task. The concept of boundary organization is compatible with what Sarec was and is therefore useful in this analysis.

With boundary organization I mean - in line with David H Guston (1999) in his study of the US Office of Technology Transfer - one that straddles a task involving at least two distinct political areas. ${ }^{294}$ According to Guston, these organizations "internalize the contingent character of the science/politics boundary".295 The boundary, furthermore, is constantly negotiated and its success depends on the satisfaction of the organization's political principals (patrons: politicians) and scientific agents (performers: researchers in this case). ${ }^{296}$ These are concepts that Guston borrows from Stephen Turners principal-agent theory, assisting in explaining the way by which one actor delegates tasks to another, one that is presumably more capable of performing them; "an extension of self by delegation."297 Guston calls the boundary organization a site that

291 Cozzens, S. E., R. Hagendijk, et al. (2007). Research Summary 3: A Framework for Analyzing Science, Technology and Inequalities: Preliminary Observations. p2

${ }^{292}$ Healey, P., S. E. Cozzens, et al. (2008). Review Report: Policy Issues and Options in ResIST and the CARE model. pp4-5

${ }^{293}$ Ideas inspired by the conference session: Bauchspies, W. and V. Gyberg Brodén (2013).

Decolonization of Science and Technology: Why?, About Time!, or Impossible. 4S. San Diego.

${ }^{294}$ Guston, D. (1999). "Stabilizing the Boundary between US Politics and Science: The Role of the Office of Technology Transfer as a Boundary Organization." Social Studies of Science 29(1): 87 111.p87

295 Ibid. pp90-91

296 Ibid. p91

${ }^{297}$ Braun, D. and D. Guston (2003). "Principal-agent theory and research policy: an introduction." Science and Public Policy

30(5): 302-308. p303 
enables stabilization and facilitates the co-production ${ }^{298}$ of both knowledge and social order with their differing logics of action - fulfilling both scientific and political interests. ${ }^{299}$ Boundary organizations, he maintains, also enable the production and use of boundary objects ${ }^{300}$ (such as a patent or a report) which sits "between two different social worlds, such as science and non-science, and they can be used by individuals within each for specific purposes without losing their own identity"301

The political principals may have the money and interest to perform a task, for instance, but not the necessarily skills or time. In the case of research aid, the government delegated the task to Sarec for example. The task of research aid has other principals as well, the Ministry of Foreign Affairs and the Ministry of Education. Sarec was also a principal since they in turn funded various different actors; international research organizations, universities in low-income countries, and Swedish universities. This was the case both when it was an independent agency and when it was part of Sida. ${ }^{302}$ There can also be professionalized mediators which in this case could be administrative staff at Sarec or universities (staff who may well have a PhD for example but that are not employed to conduct research, rather mediate it). ${ }^{303}$

The assumptions about principals and agents are built upon perspectives from institutional economics that assume some sort of rational actor behavior that is driven by self-interest. ${ }^{304}$ I believe it is more appropriate to talk about bounded rationality, assuming individuals and actors can only possess partial information. ${ }^{305}$ The issue of selfinterest will not be explored too deeply in this context, but it is worth noting that Braun and Guston have concluded that the relationship between political principals and scientific agents is often one of relatively productive mutual dependence, meaning that conflicts and cheating (or "shirking") are not a big problem in general. ${ }^{306}$ Elizabeth Shove,

298 With reference to Jasanoff, S. (2006). States of Knowledge: The Co-production of Science and the Social Order, Routledge.

${ }^{299}$ Braun, D. and D. Guston (2003). "Principal-agent theory and research policy: an introduction." Science and Public Policy

30(5): 302-308. pp305-306

300 With reference to Star, S. L. and J. Greisemer (1989). "Institutional Ecology, 'Translations' and Boundary Objects: Amateurs and Professionals in Berkeley's Museum of Vertebrate Zoology, 1907-39." Social Studies of Science 19(3): 387-420.

301 Guston, D. (2001). "Boundary Organizations in Environmental Policy and Science: An Introduction." Science, Technology, \& Human Values 26(4): 399-408. p400

302 As mentioned in chapter one, after 2008 Sarec changed names and the organization changed significantly a couple of times, and the number of staff has been reduced by half. For this reason I am treating research-aid post-2008 essentially as a new form altogether.

303 Guston, D. (1999). "Stabilizing the Boundary between US Politics and Science: The Role of the Office of Technology Transfer as a Boundary Organization." Social Studies of Science 29(1): 87 -

$111 \mathrm{p} 93$

304 Braun, D. and D. Guston (2003). "Principal-agent theory and research policy: an introduction." Science and Public Policy

30(5): 302-308. p303

305 See for example Simon, H. A. (2000). "Bounded Rationality in Social Science: Today and

Tomorrow." Mind \& Society 1: 25-39.

306 Braun, D. and D. Guston (2003). "Principal-agent theory and research policy: an introduction." Science and Public Policy 
on the other hand, maintains (in an article about directed research programmes) that while principal-agent theory's level of abstraction can be an asset, co-production is a better way to talk about the relationship between political and scientific actors. This is because while there may be productive mutual dependence between them, political principals cannot effectively control the scientific agents - they become principals of their own. ${ }^{307}$

As discussed earlier, from a discourse theoretical perspective Sarec, the annual reports, its staff and directors can be seen discursive agents that act and are acted upon in different ways depending on their context. The figure below visualizes the boundary organization Sarec and its principal and agent relations.

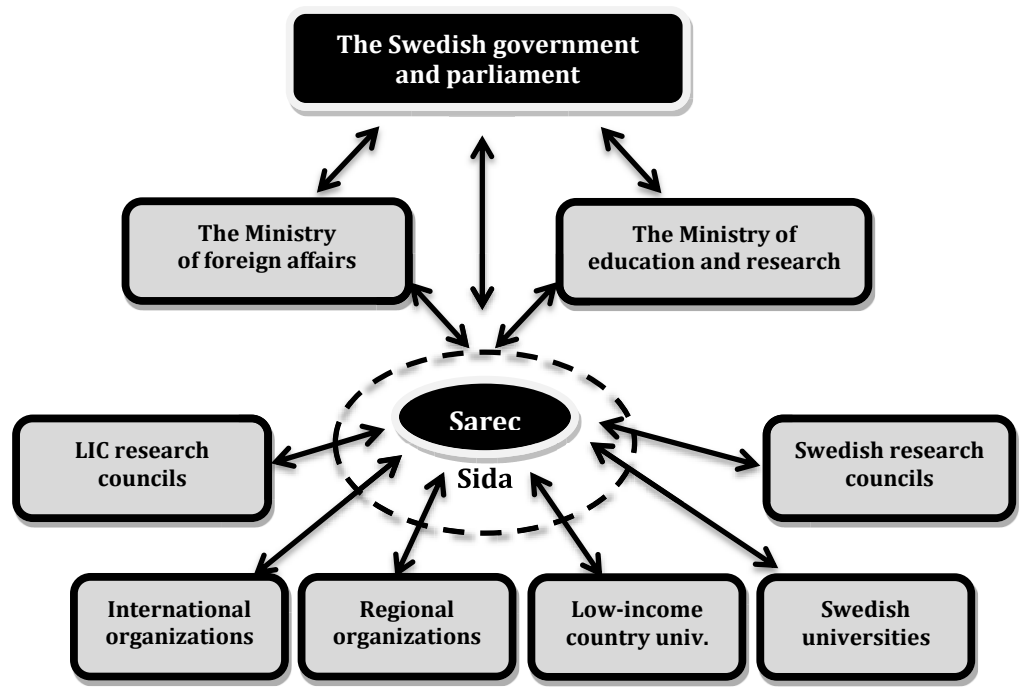

Figure 3: The boundary organization

The research aid organization is both principal and agent, as illustrated above. The parliament provides instructions, but the policy is also influenced by, and concerns, the ministries of foreign affairs and education and research. Much of what I focus on does not concern the organization per se, however, the relationships are discussed from the point of view of the documents and interviews. Guston's ideas are useful to describe and understand the place of Sarec since they specifically deal with the relationship between politics and science.

30(5): 302-308. pp306-307

307 Shove, E. (2003). "Principals, agents and research programmes." Science and Public Policy 30(5): 371-381. p372 


\section{Summarizing key theoretical assumptions and concepts}

Informed by both Foucault and Fairclough, I understand discourses as historically situated practices (such as speech and written text) which contribute to the formation of the objects and the identities of subjects that they refer to. Discourses actively construct that of which it speaks; the idea of universities and researchers in low-income countries for example. Many different interpretations and constructions of the physical and material world are possible. Having said this, I adhere to a mutual constitution perspective and also believe that the physical world has agency. Natural and man-made objects or artefacts have physical properties, and sometimes also inscribed politics ${ }^{308}$, which can affect how we are able to interact with them. In the same way, historical contexts and path dependencies place limits on the amount of possible actions and interpretations in any given situation. So even though there are many functions one could imagine a physical object having, what we end up doing with it is conditioned by both our preconceived notions as well as the object's size, shape and potentially intended uses via designers and so on.

How development is constructed depends on how it has been constructed previously, on what we conceptualize as not development as well as how the objects it refers to materializes in different ways. Development is often associated with "eliminating" or "reducing" poverty for example - creating economic growth, prosperity and well-being. Concretely we might think of things like children being able to going to school, thriving "productive" sectors (industries and businesses for example) and people earning sufficient income to feed their families, access health care etc. Of course there are conflicts surrounding these associations. ${ }^{309}$ There are struggles about the right to define problems and their solutions, but in any given time period a certain set of interpretations and definitions will appear as more reasonable than others.

Swedish official research aid policy affects and is affected by different actors, contexts and ideas. The influence theoretically flows in all directions, but in this case the focus is on how the policy documents and interviews construct research for development, thereby directly and indirectly contributing to some potential futures and not others. While keeping in mind that there is room for change and resistance within all these spaces, I argue that Swedish research aid discourse (as constructed by texts such as annual reports, parliamentary proceedings, evaluations and interviews with former directors) is partly constitutive of how universities in low-income countries come to contribute to development. It is also constitutive of how they are perceived to do so by

\footnotetext{
${ }^{308}$ See for example Winner, L. (1986). The Whale and the Reactor: a Search for Limits in an Age of High Technology., University of Chicago Press.

309 On a related note, according to an analysis of Swedish media coverage between 2011 and 2012 on foreign aid to Africa, it is most common to illustrate news stories pertaining to foreign aid with images of starving children, white aid workers or Swedish school classes. Retriever Sverige, A. Retrieved December, 2013, from http://www.mynewsdesk.com/se/retriever/pressreleases/download/resource_attached_pdf_d ocument/884760.
} 
those who take part of the documents, regardless of whether these are critical or positive readers for example. The story I am telling could be visualized like this:

THE WIDER

SOCIAL PRACTICE

SOCIAL PRACTICE

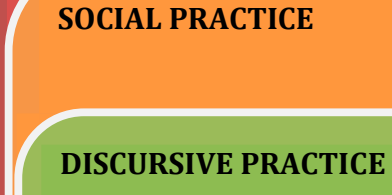

TEXT
International politics

Other international and national organizations and agencies

Swedish state politics (research and foreign aid) Universities and researchers

Actors: Principals/patrons - politicians

The research aid organization (Sarec)

A boundary organization engaging in both scientific and political work.

Actors: Principals/patrons and/or professional mediators

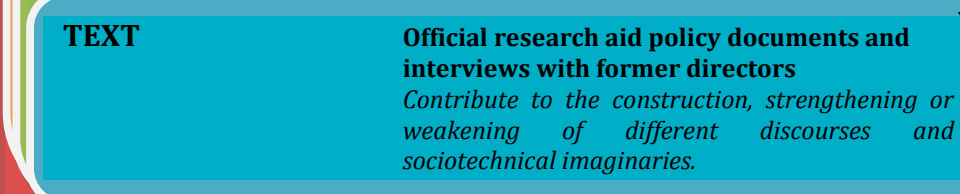

Official research aid policy documents and interviews with former directors

Contribute to the construction, strengthening or sociotechnical imaginaries.

The ideas and activities of researchers and other staff, university environments and research results internationally, in low-income countries

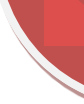

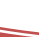

\section{Figure 4: Theoretical framework}

The texts I analyze enable the identification of several different discourses concerning the role of science and technology in development. These discourses mirror different sociotechnical imaginaries; projections by the Swedish state about certain futures and the place of science and technology within these.

\section{Some ethical considerations}

Using a critical analytical approach raises a few ethical questions that deserve attention. It demands an ability to somehow determine what inequality or injustice may consist of since one would effectively have to take some sort of stand. The knowledge and experiences of the "West" continue to be dominant, even though voices from all parts of the world are increasingly influencing the perspectives. Neither development agencies nor universities are neutral actors; hence they continually contribute to constructing certain discourses and potential futures while excluding others. By attempting to understand which discourses are strengthened and which ones are excluded, one creates 
a space for potential critique and change. Development policy is one place where struggles to define futures very clearly take place.

STS has always been critical of how science and technology have been portrayed in different contexts for example, further adding to the push to "take sides." STS is critical of technological determinism and universalistic views of scientific work and development, something which may directly or indirectly favor more pluralistic views. Foucault's theory also questions linear accounts of historical development. I argue that even though I share a critical perspective of linear accounts, the primary aim in this study is to identify different discourses and how they are built up and how they evolve during a specific period. As Sismondo puts it, "the study of rhetoric is crucial to understanding what people believe and why they believe it." 310

To use the terminology discussed by STS researchers Vasilis Galis and Anders Hansson (inspired by Brian Martin's book Confronting the Experts from 1996) perhaps my approach could be placed somewhere in between de facto and overt partisanship. ${ }^{311}$ I would argue that one can strive for a certain distance to theory, the empirical material, as well as one's preconceived notions of them while also acknowledging the situatedness of the researcher. In other words, rigorous and consistent application of theory and methodology along with the ambition to be explicit about one's own stance increases transparency and makes the results of this study credible though not everybody may agree with the results. Using the words of Fouacult: "Perhaps in the end, what I must do is take caution to be explicit about what I am doing, without trying to dictate what is to be done." 312

I do not claim to explain any ultimate origin, nor to judge whether any given discourse is "good" or "bad" per se. I do not necessarily take sides with a particular discourse identified in my material; I see it as a challenge to not take any claims for granted. I systematically examine how the objects and subjects are constructed in my material - regardless of discourse - and question in what way this portrays the conditions and options of the people the policies aim to assist. And despite the fact that I can sometimes be critical of how the role of science is constructed in this case for example, my stance is not that science "itself" is bad. My perspective is also in line with that of for example STS researchers Wenda Bauchspies and Sal Restivo in their 1996 article How to criticize science and maintain your sanity, who essentially make the case to not throw the baby out with the bathwater. Science and its many contexts can and should be criticized - this does not mean that critics (in this case, social constructivists) are anti-science. ${ }^{313}$

\footnotetext{
${ }^{310}$ Sismondo, S. (2010). An Introduction to Science and Technology Studies (2nd ed), WileyBlackwell. p156

${ }^{311}$ In line with for example the arguments of Galis, V. and A. Hansson (2012). "Partisan

Scholarship in Technoscientific Controversies: Reflections on Research Experience." Science as Culture 21(3): 335-364. pp5-7

312 Graham, L. J. (2005). Discourse analysis and the critical use of Foucault. Australian Association for Research in Education. Sydney. p6 citing Foucault, M. (1980). Questions of Method. Michel Foucault: Power. J. D. Faubion, The New Press: 223-238.

${ }^{313}$ Restivo, S. and W. Bauchspies (1997). "How to criticize science and maintain your sanity." Science as Culture 6(3): 396-413.
} 
While I definitely do not claim that this interpretation of Sarec's policies is the only possible one, I believe that it is a well-grounded interpretation. So what type of conclusions I can draw from my study when using this type of theory? I feel confident that I can point out certain patterns, but could I provide policy advice on the basis of this for example? I am not so sure, given that I am only investigating part of the research aid practice. What I can do, however, is use the patterns identified in the policies and speculate with the help of previous research and different theoretical perspectives. A kind of perspectivism in other words. ${ }^{314}$

314 See for example Giere, R. N. (2006). Scientific Perspectivism University of Chicago Press pp23 


\title{
3. Methods and materials
}

\begin{abstract}
Genealogy is gray, meticulous, and patiently documentary. It operates on a field of entangled and confused parchments, on documents that have been scratched over and recopied many times. [...] To follow the complex course of descent is to maintain passing events in their proper dispersion; it is to identify the accidents, the minute deviations - or conversely the complete reversals - the errors, the false appraisals, and the faulty calculations that give birth to those things that continue to exist and have value for us. ${ }^{315}$
\end{abstract}

- Michel Foucault (1977)

The purpose of this chapter is to explain what I have done, how and why. More precisely, to discuss what methods and materials I have used in order to answer my research questions - and why. My theoretical and methodological point of departure is a discourse analytical perspective. The theoretical underpinnings of discourse analysis have been discussed in the previous chapter. Here I will concentrate mostly on the concrete implications of these in the research process.

The material used by discourse analysts often includes text of some kind which can be both written and spoken (or images). This implies that other literature is also relevant to consider in order to create a clear account of how this study has been conducted - literature about document analysis and interviews for example. ${ }^{316}$ I will begin by outlining the premises of discourse analysis before presenting the material and discussing how I went about analyzing it.

\section{Doing discourse analysis}

Why use discourse analysis? Howarth claims that the objective of using discourse analysis is "the production of novel and plausible interpretations of selected cases and problems". ${ }^{317}$ The aim of discourse analysis is not to uncover "truth" nor to establish causality - but to provide well-founded interpretations and analyses of the chosen material. So how does one do that? The instructions range from very few to relatively detailed depending on which school and/or author one consults, but they are compatible with much of what is recommended in social science research methods in general.

This openness in purpose could be considered vague, but it allows room for many types of studies and it mirrors the ontological and epistemological points of departure of discourse theory. Foucault was not known for methodological stringency, for example, but the way he describes the genealogical approach (above, and in chapter 2) in

\footnotetext{
315 Foucault, M. (1977). Nietzsche, Genealogy, History. Language, Counter-Memory, Practice M. Foucault, Basil Blackwell. pp139 \& 146

316 See for example the discussion about referring to other methodological theory in Howarth, D. (2000). Discourse, Open University Press. p140

317 Ibid. p142
} 
my opinion captures very well the motivation, process and challenges involved when attempting to engage with 30-40 years of historical development in a meaningful and methodologically rigorous way. His lack of explicit methodological guidelines is clearly not a reason to avoid being methodologically rigorous.

Fairclough places more emphasis on analysis of small rather than large amounts of material - but he also makes room for those of us who instead want to analyze a whole corpus or larger body of material in broader terms. ${ }^{318}$ The issue of how to select samples for more detailed analysis may be more challenging with a large amount of material, but nevertheless the process is much the same. Discourse analysis is, according to Fairclough, suited for "interdisciplinary undertaking" in the sense that several perspectives (from history, sociology or political science for example) may be required in order to adequately account for the different levels in his definition of discourse. ${ }^{319}$ In the same way, I would argue, there is no reason why methods from all of these areas cannot be used.

A form of open coding is a common place to start in analyzing text, identifying things like conflicts, repetitions, misunderstandings or sudden shifts of style. ${ }^{320}$ This assumes some form of prior knowledge about what might be reasonable to expect of this particular material. ${ }^{321}$ There are more detailed guidelines available as well, ${ }^{322}$ and though these might be excellent help in cases with less material, I find the general conceptualizations of discourse and more general advice to be sufficient as guidelines in the analysis in this case. These are used together with complementary methodological literature on document analysis and interviews. I do pay attention to vocabulary and also highlight some aspects of intertextuality for example, but the general focus is on the development and change of ideas, discourses and imaginaries in the texts covering several decades so the level of detail in my analysis of each text is not as dense as Fairclough might prescribe, for example. ${ }^{323}$

The accounts of the social and discursive practice in this study are necessarily limited. I do not directly study the context in which the texts are produced for instance, nor do I investigate different receivers' process of reading and interpreting texts. I start in the social practice by discussing the politics and theory of research aid (in the introduction), to then discuss the discursive practice (about Sarec - in previous research and also in the empirical chapters) together with a more close immersion in the analysis of the central texts (in the empirical chapters). The concluding chapters tie back to the discursive and social practice levels more explicitly by interpreting what the analysis of texts might imply in relation to the Swedish case and the politics of research aid in general.

\footnotetext{
${ }^{318}$ Fairclough, N. (1993). Discourse and Social Change, Polity Press. p230

319 Ibid. p226

${ }^{320}$ So is the case also in the guidelines in ibid. p230

321 Ibid. pp232-238

322 Specific conceptualizations related to the close analysis of texts, such as distinguishing between vocabulary, grammar, cohesion and text structure.

${ }^{323}$ As exemplified in the analysis guide in Fairclough, N. (1993). Discourse and Social Change,

Polity Press. pp231-238
} 


\section{Material}

The annual reports and policy and methods documents are central to my analysis. They have been chosen as central because they are public documents explicitly aimed to inform various outside stakeholders and other instances about what Sarec did, why and how. The annual reports were also published consistently, something which enables relevant and interesting comparison over time. Complementary and also very important materials are interviews with former director generals as well as certain evaluations. I focus mainly on the large all-encompassing evaluations; they provide an external view of Sarec's activities at 10, 20 and 30 years of existence. They are comparable in their size and/or significance and provide interesting contrast.

\section{The documents}

The documents are presented in the table below and more details and issues coupled with the process of analysis are discussed further on. In addition to the central documents presented below, I have consulted a number of state investigations and parliamentary records/government documents, some smaller evaluations, reports, brochures, conference papers and position papers. Secondary literature critiquing the activities of Sarec in different ways provides additional contrast. These additional materials have been used because they were referred to in the annual reports or because they in other ways tie into central issues concerning the context of that particular decade's policy.

Most of the central material; the annual reports, methods documents and evaluations, were available at the LiU library but some were borrowed from Sida's archive or accessed through their website database. I used online databases and search engines such as Web of Science, Scopus, Libris and Google Scholar to find previous research. I also used the LiU library (for books, older journals, and government documents), the Swedish parliamentary records website (riksdagen.se) and aid organization websites. Keywords used in searches, alone and in various combinations were: developing countries, lowincome countries, capacity building, capacity development, universities, development, foreign aid, research cooperation, research capacity, research aid, aid effectiveness, aidefficiency, knowledge for development, science and technology for development, knowledge, foreign aid and universities. Keywords in Swedish included: Sarec, ulandsforskning, u-forsk, forskningssamarbete, utvecklingsforskning, ulandsforskningsutredningen, högre utbildning, forskning för utveckling, Sida.

\section{Documents List}

\begin{tabular}{|l|l|}
\hline Annual reports & - Sarec's first year 1975/1976 \\
& - Sarec's second year 1976/1977 \\
& - Sarec's third year 1977/1978 \\
\hline & - Sarec - annual report 1978/1979 \\
- Sarec - annual report 1979/1980 \\
- Sarec - annual report 1980/1981 \\
\hline
\end{tabular}




\begin{tabular}{|c|c|}
\hline & 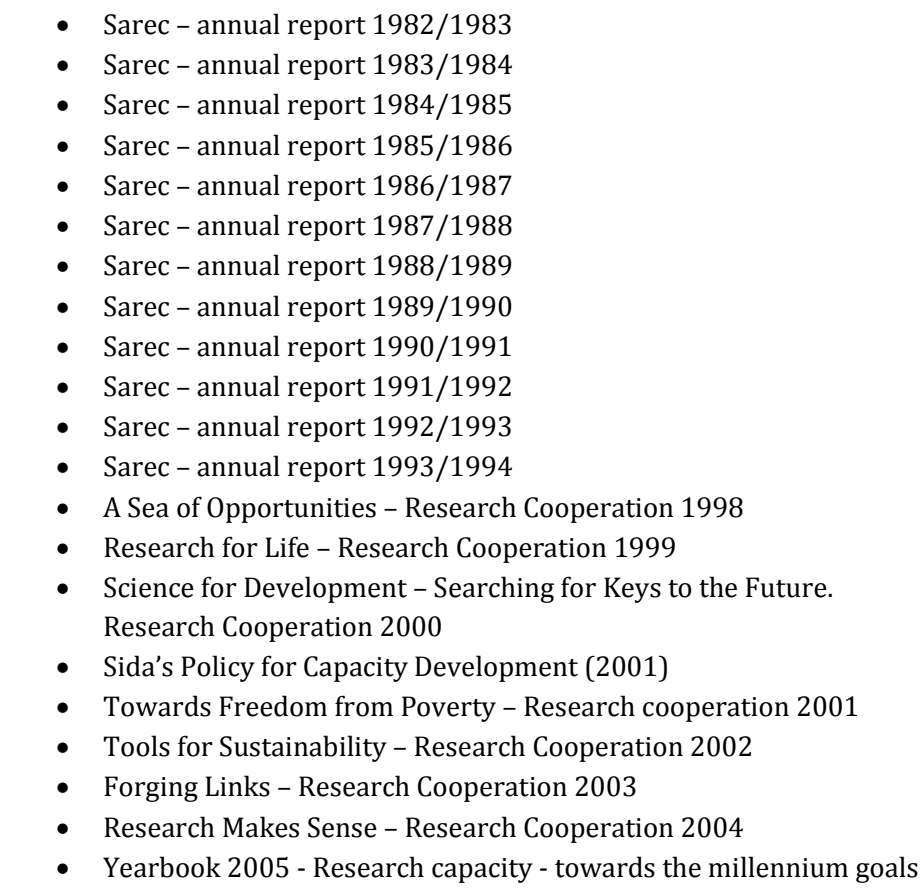 \\
\hline $\begin{array}{l}\text { Policy and methods } \\
\text { documents }\end{array}$ & $\begin{array}{l}\text { - The SAREC Model: Institutional Cooperation and the Strengthening } \\
\text { of National Research Capacity in Developing Countries (1992). } \\
\text { - Research Cooperation I - An Outline of Policy, Programmes and } \\
\text { Practice \& Research Cooperation II - Trends in Development and } \\
\text { Research (1998/2000) } \\
\text { - The Ownership and Cultivation of Knowledge - The rationale for } \\
\text { Swedish support to universities in developing countries (Berit } \\
\text { Olsson, 1992) } \\
\text { - Sida's Policy for Capacity Development a Strategic Question in } \\
\text { Development Cooperation (2000) } \\
\text { - Sida's Manual for Capacity Development (2005) } \\
\text { - Time for Rethinking - Capacity Development in a Changing } \\
\text { Policy för forskning inom det Svenska utvecklingssamarbetet } \\
\text { 2010-2014 och strategi för Sidas stöd till forskningssamarbete } \\
\text { 2010-2014 (2009) }\end{array}$ \\
\hline $\begin{array}{l}\text { Evaluations and } \\
\text { reviews }\end{array}$ & $\begin{array}{l}\text { The larger evaluations: } \\
\text { - Tio år med Sarec. En utvärdering av SARECs verksamhet med } \\
\text { särskild tonvikt på de bilaterala insatserna, } 1985\end{array}$ \\
\hline
\end{tabular}


- Research for Development. Sarec 20 years, 1995

- Review of Sida's Research Cooperation. Synthesis Report, 2006

- Sida/SAREC Bilateral Research Cooperation: Lessons Learned

- SARECs stöd till svensk u-landsforskning

- Sidas U-landsforskningsråd

- Evaluation of Sida Information and Communications Technology Support to Universities

- Organisationsstudie av SAREC

- SAREC Support to International and Regional Thematic Research Programs 2000-2005. Individual reports and cases

- SAREC Support to International and Regional Thematic Research Programs 2000-2005. Main report

The annual reports were produced at Sarec and sent out to various stakeholders like the Swedish government as well as universities in both Sweden and in low-income countries as a way to spread information about the activities being undertaken and results being achieved. The reports were also made available at Sida, and in the 2000's, they were (along with other documentation like evaluations) made available on Sida's website.

The annual reports are generally between 40 and 80 pages long and their layout, content and level of detail concerning undertaken activities vary over time. For example, certain years the introduction is rich in critical reflection, essay-like, and signed by the director, and other years the introductions are short, formal, and anonymous. Almost all of the annual reports contain the following: an introduction that included a statement on the task of Sarec, a list of the various programmes and projects (modes of work and activities as I usually call them), information about collaborating countries, budget allocations, and a list of the Sarec board, staff and publications. Activities are sometimes presented according to continent and country, sometimes by programme area or thematic area. All of the annual reports are in English.

With the exception of the years 1995-1997 and 2005-2008, Sarec produced annual reports the whole period. The documents available for the gap 1995-1997 and 2005-2008 are Sida's general annual reports (which are far less detailed), parliamentary records, Sida country reports and various evaluations.

During the first 15 years (1975-1991), there was no separate document focused on outlining the policy and methods of work; this was instead described in the annual reports and was based on the initial instructions as stipulated by the government and the committee on development research. Perhaps there were internal documents which I have not managed to come across, but to the best of my knowledge the first Sarec document to exclusively discuss policy and methods is from 1992. The next document (and last major policy and methods-related document in the period being studied) was published in 1998 and reworked somewhat in 2000. Other policy and methods-related 
documents (such as certain position papers and Sida policies) were also included when deemed of relevance (additional contrast on a certain topic for example).

Several evaluations of Sarec's work were produced each year, both small and large. The evaluations were mainly externally commissioned, meaning that either individuals, teams of consultants or researchers conducted them. Some are thematic (covering certain prioritized themes/areas or projects, for instance support to social sciences or biotechnology); some were methods-related (covering for example support to international organizations or regional research networks), and some were country or region-specific.

The three most central evaluations are very different in terms of scope, content and length. The one from 1985 (Tio år med Sarec. En utvärdering av SARECS verksamhet med särskild tonvikt på de bilaterala insatserna) was written by five researchers and mostly focused on bilateral support (around 100 pages). The Ministry of Foreign Affairs also published a shorter version of the report in English in 1986 (SarecThe First Decade). The 1995 publication (Research for Development. Sarec 20 years) is not an evaluation per se, more of a review, but it fills a similar purpose as the evaluations since it provides outside perspectives on the activities of Sarec at important junctures in time. It is around 200 pages long and written in anthology-like form by a larger number of researchers. The 2006 evaluation consisted of six separate evaluations by groups containing both consultants and researchers, comprising in total over 500 pages. The evaluations were also summarized in a report of around 50 pages (Review of Sida's Research Cooperation. Synthesis Report).

The evaluations and their recommendations likely had different kinds of influence on Sarec and later Sida-Sarec. Some of this influence is explicitly traceable in subsequent texts. The 1985 evaluation for example was discussed in parliament and resulted in a new agency instruction for Sarec while the 1995 review and 2006 evaluations both seem to have received less explicit attention afterwards. This could be due to the fact that they were both published during or around the time of large reorganizations or political elections for example, but the study does not enable me to establish that kind of causality.

Some state investigations and other parliamentary records are key texts. The 1973 state investigation which led up to the creation of Sarec was the most important one in the sense that it contains many of the seeds to ideas and policies which are later traceable all the way to "the end." There are, however, many other state investigations and government bills which in some way relate to or discuss of Sarec's activities, priorities and budget. A government bill from 1994 (Proposition 1994/95:100), for instance, is important in the sense that it was right before Sarec and Sida were merged - it discusses some of the reasons for the merger.

There are also transcriptions of debates and discussions in parliament which are electronically searchable, and some of these discussions concern the policies and direction of Sarec and Swedish research aid. I have mainly referred to these types of documents when they in some way appeared as central in relation to the events discussed in the central material (for example, if an annual report referred to a parliament decision). 
Sometimes I also used this kind of material to understand key events such as the instatement of Sarec, the dates surrounding major evaluations (roughly every ten years) and large organizational changes. All of these documents are in Swedish.

Other documents include brochures, position papers, and conference papers. They have in common that they discuss and/or briefly present and reflect the work of Sarec. I have also searched for critique or debate about research aid for each decade of Sarec's existence since I believed it could provide interesting contrast to my main material. I found relevant material to this effect in books, scientific journals, and in magazines. Some of these are discussed in previous research, but most of them are discussed in the empirical chapters.

\section{The interviews}

I conducted eight formal interviews in total, seven with former and current directors, and one with another key informant. All the former director generals of Sarec have been interviewed, with the exception of Karl-Erik Knutsson (the first director), who passed away in 2002. I interviewed Björn Hettne (key informant) - who in addition to having been Knutsson's assistant in the 1970's also wrote the appendix on development theory to the SOU 1973:41 and a number of subsequent Sarec publications on development theory.

The background of the directors is presented in a very concise manner below. The previous appointments listed represent only selected examples from their careers. Several of the formers directors had worked for many years at Sarec prior to going into that position. The decision to interview only Sarec directors was based on the assumption that they had a broad understanding of the policy and activities of the organization. This kind of perspective is a good match with my research questions which are also concerned with a relatively general level. I use "directors" for short.

\section{Name Short background information}

Lars Anell Director general, Sarec (1980-1983). Academic background in economics, Stockholm School of Economics and Stockholm University. Currently chairman of the Swedish Science Council Board. Previous appointments include: the Ministry of Finance (1966-1970), the Ministry of Foreign Affairs (1970-1978) chairman in the UN Intergovernmental Group of Experts on Science and Technology (1980-1982), senior adviser to the Swedish prime minister's office (1983-1986), UN ambassador in Geneva (1986-1992) and ambassador, Head of Sweden's delegation to the European Communities (1992-1994) and senior vice president of Volvo (1992-2001)

Bo Bengtsson

Director general, Sarec (1983-1991). Academic background in agricultural science (PhD), Swedish University of Agricultural Sciences. Currently retired and consultant. Previous appointments include: Professor, Dept. of Crop Production Science, Swedish University of Agricultural Sciences (1999-2004), Senior Research Officer, Agriculture and Rural Development, Sarec (1979- 


\begin{tabular}{|c|c|}
\hline & $\begin{array}{l}\text { 1983), Development Expert/Weed and Pest Specialist, Ethiopian Ministry of } \\
\text { Agriculture, Addis Ababa through Sida (1966-1968) }\end{array}$ \\
\hline $\begin{array}{l}\text { Anders } \\
\text { Wijkman }\end{array}$ & $\begin{array}{l}\text { Director general, Sarec (1992-1994). Academic background in political science } \\
\text { and economics, Stockholm University. Currently senior Advisor, Stockholm } \\
\text { Environment Institute (SEI) and consultant at Tällberg Foundation. Previous } \\
\text { appointments include: Member of the European Parliament (1999-2009), } \\
\text { Assistant Secretary General of the United Nations and Policy Director, UNDP } \\
\text { (1995-1997), Member of the Swedish Parliament (1971-78), Secretary } \\
\text { General, Swedish Red Cross (1979-1988) }\end{array}$ \\
\hline $\begin{array}{l}\text { Johan } \\
\text { Holmberg }\end{array}$ & $\begin{array}{l}\text { Director general, Sarec (1995-1996). Academic background MBA, Gothenburg } \\
\text { University. Currently retired and consultant. Previous appointments include: } \\
\text { Head of Division, SIDA (1980 - 1986), Assistant Director General, SIDA (1986 } \\
\text { - 1992), Programme Director and Deputy Director General, Sarec (1992 - } \\
\text { 1995), Assistant Director General, Sida (1995 - 1999), Ambassador (1999- } \\
\text { 2003). }\end{array}$ \\
\hline Rolf Carlman & $\begin{array}{l}\text { Director general, Sarec (1996-1999). Academic background in civil } \\
\text { engineering and economics, Royal Institute of Technology (KTH). Currently } \\
\text { retired and consultant for Sida (follow-up of Sida's reorganization, for } \\
\text { example). Previous appointments include Aid advisor, Sweden's general } \\
\text { consulate, Jerusalem, Sida Country Director concerning Sweden's aid to the } \\
\text { West Bank/Gaza (2008-2010), Project manager, Sida's reorganization (2007), } \\
\text { Chargé d'affaires and aid director, the Swedish Embassy in Vientiane, Laos } \\
(1993-1995) \text {, Research secretary, Sarec (1980-1986) }\end{array}$ \\
\hline Berit Olsson & $\begin{array}{l}\text { Director general, Sarec (1999-2008). Academic background in dental sciences } \\
\text { and oral health (PhD, Docent), Lund University. Currently retired and } \\
\text { consultant. Previous appointments include: Head, Division for University } \\
\text { Support and National Research Development, Sida-Sarec (1996-1999), } \\
\text { Director of Cooperation, International Association of Universities, IAU, Paris, } \\
\text { France (1994-1996), Senior Research Advisor, Health Research, Sarec (1984- } \\
\text { 1993), District Dental Officer, HIS Hospital, Asella, Ethiopia (1973-1976) }\end{array}$ \\
\hline \multirow[t]{2}{*}{$\begin{array}{l}\text { Tomas } \\
\text { Kjellqvist }\end{array}$} & $\begin{array}{l}\text { Director, Sida Secretariat for Research Cooperation (2008-2010). Academic } \\
\text { background in technoscience studies (PhD), Blekinge Institute of Technology } \\
\text { and human geography, Stockholm University. Currently research Manager, } \\
\text { Blekinge Institute of Technology, Technoscience studies and Vice Chair, } \\
\text { Swedish National Commission for UNESCO. Previous appointments include: } \\
\text { Head of Division for Natural Sciences and Technology for Sustainable } \\
\text { Development, Sida (2007-2008), Head of Division for ICT in Development and } \\
\text { Sida's Development Research Council (2000-2002), Senior Research Advisor } \\
\text { at Sarec, Sida (1995-2000), Research officer at Sarec (1992-1994) }\end{array}$ \\
\hline & $\begin{array}{l}\text { Head of Sida's Research Cooperation Unit (2011 - ). Academic background in } \\
\text { geological sciences (PhD, Docent). Previous appointments include: Counsellor }\end{array}$ \\
\hline
\end{tabular}




\begin{tabular}{|l|l|}
\hline Anders & $\begin{array}{l}\text { and Chargé d'affaires (2001), Swedish Embassy, Dhaka, Bangladesh (2000- } \\
\text { 2003), Head of division for Sida Research Council and ICT for development at } \\
\text { Sarec (1998-2000), Senior research officer, responsible for Marine Sciences, } \\
\text { Sarec (1993-1996), Associate Professor, dept of Geology and Geochemistry, } \\
\text { Stockholm University (1989-1994), Research secretary, Sarec (1988-1993) } \\
\text { Sarec/INMINE/SGAB geological program, Nicaragua (1987-1989). }\end{array}$ \\
\hline Björn Hettne & $\begin{array}{l}\text { Professor emeritus in peace and development, Gothenburg university. } \\
\text { Member of the Executive Committee of the European Association of } \\
\text { Development Research and Training Institutes (EADI) throughout the 1980s; } \\
\text { Vice-President of EADI (1990-93); Dean of the Faculty of Social Science, } \\
\text { Göteborg University (1990-93); Coordinator of a series of Research Projects at } \\
\text { the UNU/WIDER, Member of the board of UNRISD. Member of the Swedish } \\
\text { Government's Expert Group on Development Issues (EGDI) (1998-2002). } \\
\text { Author and editor of 30+ monographs or edited collections on a range of } \\
\text { topics. Author of 100+ articles, book chapters and research reports, two } \\
\text { examples being Vad är utveckling [What is development?] (2008), SNS förlag, } \\
\text { and Thinking about development (2009), Zed Books. }\end{array}$ \\
\hline
\end{tabular}

The purpose with the interviews was both explorative and orienting. I asked questions in order to better understand research aid as a phenomenon, to understand the documents and to get the unique perspectives of each person on their time as director. I see interviews as co-produced accounts. In other words, the interviewer and interviewee both contribute to the account that is the result of the interview - I am not simply objectively "mining" the minds of the interviewees. ${ }^{324}$ The interviews are a kind of conversation, hence my "input" as an interviewer has to be taken into account somehow in order to adequately analyze the directors' statements. In one sense, the same goes for documents since they do not speak for themselves, I interpret and prompt, ask questions and draw conclusions from them. The interviewees' perspectives, however, were of course made available to me under quite different conditions than the documents.

Like the documents, I consider the former directors to be "discursive agents" - they contribute and relate to the construction of ideas about research for development. They align, reinterpret and reproduce certain discourses. As leaders of a boundary organization, they had to answer to principals and patrons on both the political and scientific "sides." As the material illustrates, this navigation can be quite difficult and involves a fair amount of argumentation.

The interviews were semi-structured, between one and two hours long, and conducted with roughly the same type of questionnaire (see appendix A for Swedish and English versions). The interviews were recorded and transcribed. All the informants agreed to be identified with their names, something which in this case makes the use of the interview material much more useful and relevant. Tying quotes to specific decades would not have been possible if their anonymity was to be secured.

${ }^{324}$ Kvale, S. and S. Brinkmann (2009). Den kvalitativa forskningsintervjun, Studentlitteratur. pp63-67 
The interviews were conducted between 2009 and 2013. I had a general idea of their background, but not a detailed understanding. The more time passed, the more I learned. One of the consequences of this was that I was able to ask more initiated followup questions in later interviews. I had understood the "language" of this field better. The directors also talked about each other, so the later the interview, the bigger my frame of reference became. This, however, is not something I consider problematic since the benefits of having spread out the interviews are also clear. I had time to think about what each director talked about before doing the next one, even though I asked the same questions more or less. I also became more confident.

The questions I used were partly based on my evolving research questions, and to a lesser extent adapted to the themes and issues of relevance to the time during which the person in question was director. I attempted to create a level of comparability with the interviews by using the same set of questions, but they varied slightly from interview to interview. The time for the interviews was between 1.5-2 hours. They were all recorded and transcribed. The interviewees were informed beforehand about the main themes of the interview as well as the fact that I wished to record the conversation. I also informed them that I would let them check any quotes or other references to them that I intended to use in the dissertation.

I did not experience any serious difficulty in conducting the interviews, it was a rewarding and interesting experience. That is not to say that some things were not challenging. The fact that they have had, and often still had, influential positions (though not necessarily in relation to research aid), was intimidating at times. ${ }^{325}$ They tend to be experienced in politics, negotiations, and being interviewed for example. I sometimes felt that I missed some important points to follow up, either because I was too focused on listening to some other aspect or because I did not have enough knowledge or experience to pick up less explicit statements. The transcriptions allowed me to double-check what was said; I could see and understand certain things afterwards instead.

The interview questions were on a relatively general level in the sense that they could basically be used for all the informants, though follow-up questions differed depending on whom I was talking to. It was sometimes difficult to ascertain which questions could be perceived as controversial - and by whom - not least concerning the latter time period. I found that the best thing to do in these situations was to clarify my questions, and not least the reason for asking them, and also mention that they did not have to comment if they did not want to. Having said that, all the interviewees were very open and interested in sharing both their opinions and experiences.

Given that I am interested in how these issues are perceived and presented I found the interviews to be very relevant. The issues we discussed provided valuable perspectives and contrasts to the documents. The interviews also greatly improved my general understanding of issues we discussed; it was like laying a puzzle. In hindsight of course there are things I wish I had known before talking to the next interviewee and there are issues I think I could or should have asked more about, but in general I am very

325 See for example Kvale and Brinkmann’s discussion about elites. Ibid. p163 
satisfied with the interviews. Having the transcripts meant I could re-read the first interviews much later and understand things that I did not see at the time. My transcriptions did not include all the repetitions and pauses, I aimed at getting the essential content of each "sentence" or point, and I recorded the time regularly so as to facilitate going back to listen again if necessary. I transcribed most of the interviews relatively late in the process, something which I think was positive in the sense that I listened to all of them again relatively close in time to one another, perhaps making it easier to identify patterns. As with the documents - I constructed a table to summarize main points of each interview using the same guiding points as for the coding of documents which will be discussed below.

I have not given the directors' ideas the heaviest empirical focus in this study - I have not aimed at "following the actor" or doing network analyses - even though such an approach would likely be very interesting. Research aid policy is my main object of study here, and it is influenced by many significant actors and groups, of which the directors are one. They are of course important discursive agents in their role as leaders of the boundary organization and their opinions during their time in management were presumably very significant. Nevertheless, the interviews are treated as a complement to the analysis of documents. It would have been relevant and interesting to also interview other actors such as low-income country researchers and government officials, research officers and administrative directors at Sarec, the Sarec Board, people at the Swedish Ministry of Foreign Affairs, the Ministry of Education, aid ministers, directors at Sida, or Swedish researchers and evaluators. In order to do this in a scientifically rigorous manner, however, and still maintain the long historical perspective - I would have needed more time.

\section{Working with the material}

Most of the documents from the first two decades, and many of those from the 1990's as well, were only available in paper format, hence I have done all the work with these "manually". I have not used any text analysis software, though I am aware the documents could have been scanned to enable this. I found that my central material was a manageable amount to analyze without the help of text analysis software. In those central documents that were available electronically, I still did most of the work manually, both because I wanted continuity in my method and because I just found it easier to analyze them this way. Having documents electronically searchable, however, of course made it easier to find many of them (in Sida's publication database for example). With documents in paper format I was depending on them existing in the university library catalogues for example, with relevant registered searchable terminology. The use of electronic word searches was mainly used in the documents analyzed for chapter 8 mainly, which was helpful since the amount of documents available grew exponentially with time. The 2000's had a great number of secondary material that provided interesting context, and in order to cover as many of them as possible, it was good to be able to do some elementary "mining" of them.

The methodological approach in thesis has been abductive - I have switched between inductive and deductive approaches, in line with what sociology researcher Boel 
Berner refers to as double fitting. ${ }^{326}$ It is a simultaneous production and analysis of both theory and empirical material, where trial and error with ideas, materials and hypotheses eventually (hopefully!) leads to increased levels of abstraction. ${ }^{327}$

The initial analysis of the annual reports and other documents was loosely inspired by Grounded Theory. ${ }^{328}$ I have not followed this methodology consistently, but my aim when working with the material initially was to pursue a more inductive approach. I felt that my theoretical ideas and draft research questions limited what I saw in the material and wanted to remove myself somewhat from my previous understanding about research aid. I thus tried to approach the analysis of the material more openly. This more "open" approach of course did not mean that my previous theoretical understanding and preconceived notions were suddenly gone - it still conditioned what I was able to see in the texts - but I believe that it has enabled me to think somewhat more widely about the material.

I found sensitizing concepts to be a useful way of identifying the relevant aspects in my material. Sensitizing concepts can be considered "interpretive devices" which enable starting points and inform the formulation of the research problem. ${ }^{329} \mathrm{I}$ thought about things related to capacity building, development theory, research cooperation and aid for example. My draft research questions guided my reading initially, but I put them aside after a while and tried to just read, take notes and code openly. When I say open coding I mean that I read the material and took textually close notes (without categorizing them at first) keeping an eye out for repetitions, contradictions and other things that stood out. Things that "stood out" could be the use of metaphors, the appearance of "new" concepts (like when the use of third world became replaced by developing countries for example) or references to scientific literature or specific theories. ${ }^{330}$ The exercise of coding entails interpretation and eventually more detailed categorization. This process is very similar to - and compatible with - the kind of analytical process that Fairclough recommends. ${ }^{331}$ After the first round of coding I organized my notes more clearly into categories (see below). Categories can be of very different kind - descriptive, analytical or interpreting for example. My initial categories were very descriptive. I have analyzed entire documents, sometimes zooming in more specifically on single sentences, paragraphs or ideas depending on what I considered

\footnotetext{
${ }^{326}$ Bergman, P., B. Berner, et al. (2005). Samhällsvetenskapens hantverk, Arkiv förlag. p140 inspired by 1972 Baldamus, W. (1972). The Role of Discoveries in Social Sciences. The Rules of the Game. T. Shanin. London, Tavistock Publications. 327 Bergman, P., B. Berner, et al. (2005). Samhällsvetenskapens hantverk, Arkiv förlag. pp141142 328 Which originated as an alternative to positivistic methods, Glaser, Anshelm and Strauss 1998 and 2008

${ }^{329}$ Bowen, G. A. (2006). "Grounded Theory and Sensitizing Concepts." International Journal of Qualitative Methods 5(3). P14

${ }^{330}$ Ryan, G. W. and R. H. Bernard (2003). "Techniques to Identify Themes." Field Methods 15(1). ${ }^{331}$ Although I was not explicitly applying it - parallel to this part of the empirical work I had also read some of Fairclough's work.
} 
them to be a representation of. Parallel to this process, I read theoretical literature and previous research, reworking my purpose and research questions as I went along.

Using the example of the annual reports - which are the most central documents - the initial detailed notes were converted into a table based on categories that were inspired by both the material and my research questions. The categories were: 1) task/goals and organization, 2) key concepts, 3) relationship between research capacity and development, 4) methods, and 5) other notes. The table included compact notes on all the categories and all the years in question. This enabled me to get a broad overview of the period and provided a base to return to during the progression of the work. I read other central documents several times, took notes, compared to other documents, and took new notes before writing about them.

I followed a similar process of analysis with the other documents (parliamentary records, evaluations and other reports) as I did with the annual reports and policy and methods documents, though it was in some respects a less open reading and not as detailed categorization process. I took some general notes on each document but sometimes had a more clear idea about how I was going to use them.

Regarding the interviews, I did a table similar to the one I did for the annual reports, which was organized according to the central questions in the interview guide. I systematically read through each interview transcript and took notes, ending up with a useful overview of what the interviewees had talked about in relation to central issues for the study. I used this table, as with the annual reports table, for quick orientation of the bigger picture as well as when I needed to find my way back to certain issues. I could look through the tables and remember where something was talked about, and then go to the original report or transcript and verify, check the context, compare, etc.

Though the analytical process could have been documented with even more stringency, these tables together with all my drafts and notes provide evidence of systematic work with the empirical material and would allow others to follow how I have come to tell the story of Swedish research aid policy and the conclusions I have drawn.

\section{Identifying discourses}

Theories about development and knowledge production are at times actively "enrolled" in the texts. With development theory I mean ideas about how countries change, and should change, over time and why - ideas which are central to how foreign aid is designed and implemented. Knowledge production theories encompass ideas about how knowledge plays into this change, including scientific research. Discourses have been labeled, described and analyzed using concepts embedded in the empirical material, which can often be coupled to the type of theories described above.

The work process concerning identification and naming of discourses has been closely related to the analysis in general. I have looked for both recurring patterns and discontinuities of different kinds by reading and re-reading documents and interview transcripts, taking notes and so on, as described above. As my research questions and theoretical positioning and tools became more defined, I started thinking about how these patterns and discontinuities could be explained, understood and presented in relation to 
the bigger context of each decade, nationally and internationally. A process of layering occurred where I piece by piece tried to understand what certain variations in definitions in the documents could mean in relation to development theory trends and research policy ideas for example. What views of science and technology did they contain and how was that made visible?

My understanding of different development theories or theories of knowledge, for example, enabled me to identify patterns of reasoning that reminded of one theory or another. These observations were then cross-checked with secondary literature, the interviews and other documents. I may, for example, have gotten the impression that a certain argumentation surrounding bilateral cooperation was in line with a linear view of innovation, or that it straddled two very different theories at the same time. I would then try check whether this was a reasonable interpretation and specify what I saw by triangulating several materials and eventually provide a wellanchored analysis. I also questioned what else it could mean, and tried to provide alternative interpretations, which of course meant that the analysis changed a number of times. Looking at "the whole" also lead to adjustments, my understanding and portrayal of the 1970's were improved when I better understood the 1980's and so on.

Undoubtedly, one risks missing certain trends depending on preconceived notions, and one's research questions and theories may increasingly shape what is visible, but I have aimed to show the diversity in the policy development. Choosing a genealogical approach of sorts helps, and reminding oneself of what that is from time to time is a good way to remember to avoid simplifying where the material does not really lend itself to simplification. Is the policy development to be interpreted like the competition between two or more major separate discourses, or is it one discourse with many branches which share the same roots? Asking questions like these forces a testing of the categories one develops. Given the fact that the amount of material is significant, it is necessary to simplify to some extent of course, and I cannot account for all the variations and continuities in the policy.

Relatively late in the work I decided to use objects to follow and discuss the most central concepts to my research questions in a slightly more abstract way. Objects, as discussed in the theory chapter, are central building blocks of discourse. Development, for example, is a central object. How is development as an object constructed in relation to research aid? Is it economic development, is it social development, capacity building, or something else? Research capacity is another central object; and together these different constructions have consequences for the characteristics of research aid discourses. It is possible to identify certain patterns and sociotechnical imaginaries that can be identified with one or more development theories or knowledge theories for example. The same objects can be defined differently by different discourses, meaning that though building research capacity may be a central goal in all the decades of Sarec's existence, its meaning evolves and in that way it is possible to say that the discourses also change in character.

In line with this kind of reasoning, one might call discourses universalist or localist for example. This is a simplification, no doubt, but their generality allows for 
discussion of the heterogeneity and complexity in the policies. My categorizations are a construction based on different theoretical perspectives as well as the material studied, a way to analyze the ideas through a certain logic. The construction of objects differ during one and the same decade - the discourses overlap and exist side by side. I do not think either discourse necessarily exists in "pure" form in the sense that I would not claim that any of the former Sarec directors would have adhered to only one side of the ideational spectrum. Diversity and contradictions are to be expected, but it is nonetheless be productive to highlight some of the possible influences in policy developments.

\section{The order, structure and contents of the empirical chapters}

The way the story is told is based both on a chronological presentation of the events as well as a thematic analysis of the discursive development in the documents and interviews. Since the study is a genealogy of sorts I have tried to capture both continuities and discontinuities. I have tried to contextualize the analysis in both its discursive and social practices. Doing both the historical contextualization and the analysis of central material - and finding a balance between them - has been one of the biggest challenges in this process. The work with chapter 1 and its long background part, for example, started relatively early in the process as a way to get oriented in the field. I waited until quite late, however, to work with the contextualizing literature in the empirical chapters. In retrospect, this seems like a good thing because I was able to focus on understanding and analyzing my material. I then opened up the box of contexts again more towards the end and used it as a way to tie the story together when I had begun to see the whole picture.

Though the end result has both strengths and weaknesses, I find that it was justified to structure the chapters this way. Only being able to hint at some of the contextual factors (and completely omitting many factors) was necessary in order to leave enough space for the main empirical material. The parallel histories of foreign aid and research aid politics, however short and concise, enabled a more interesting analysis.

As far as the layout within the chapters themselves, there is something of a pattern, though each chapter has its own logic as well. The introductory part is usually followed by a more empirically close analysis of the annual reports and other central documents. The chapter is then rounded off with more thematically oriented discussion about the decade's policy development. Having said that, I also discuss important investigations, evaluations and other events - and they are included in different ways in each chapter.

I see the analytical process as a continuous exercise, and I have also included concluding discussions in all of the empirical chapters. In other words I have not endeavoured to save all my analytical observations and conclusions to the last chapter.

\section{Validity}

The main object of study is policy and how the aid actor chooses to describe its task, principles, and methods in various documents and in interviews. Regarding the policy documents, I am well aware that what ends up on paper - in an annual report for example 
- is a relatively clean version of the actual real life diversity of opinions and interpretations in an organization. It is also reasonable to expect that written policy reflect this diversity to some extent - which can result in contradictions. Nevertheless, the contents written down on paper can reasonably be seen as an expression of will and direction of Sarec as a state agency.

What I am doing is constructing one specific type of interpretation of my chosen material. The texts, people, the agencies and universities are "out there" and continuously constructed and interpreted repeatedly and in different ways by different people in different contexts. I have made an effort to include a diverse array of materials as well as secondary literature in order to provide a nuanced picture of Sarec's policy development. Studying the subject with different materials and methods increases the credibility of my interpretations. I have aimed at capturing the diversity of the material, but there are likely issues that I have missed which would have been interesting to include. I do not believe that these issues would render my analysis incorrect in the sense that I am identifying relatively general tendencies.

One may question the choice to focus mainly the textual representations of policy, since it does not say so much about the effects of policy. I could have for example conducted an ethnographic case study in a low-income country university instead. That, however, would have required me to focus on a shorter time-span and a more narrow part of the research cooperation policy. This is something I might be able to do later on. My conviction is that the heavier focus on policy development is interesting and relevant - particularly when applying a longer historical perspective. Analyzing how the organization chooses to publically portray itself, its task, and choices of methods over time can result in the identification of patterns and dilemmas which can then be contrasted with other types of materials. The policy material was rich and interesting and relatively easily available. The memories of directors from the early periods may in some senses less be considered reliable than the memories of directors who were responsible more recently. This might be the case, but the early directors may have been able to highlight different aspects with the benefit of hindsight. All the interviewees have provided invaluable input in different ways, something which I think has been able to be put to use in the thesis. A deeper focus on documents complemented with input from the interviews is priority-wise a compromise that allows for both depth and width. Each type of material added to my understanding and ability to see things from different perspectives. Together, I believe these approaches can result in a useful and interesting picture of how research aid policy has developed and changed in the last 40 years. 


\section{Previous research}

It is easy to understand criticism which says that it is an issue of the decision makers' power and values - not a lack of knowledge and reasonable thinking - which causes the large global injustice, poverty and the skewed, preventable diseasedness. [...] Why else do at least six million children under the age of five die annually despite the fact that there are scientifically proven interventions that can prevent most of the deaths (respiratory diseases, diarrhoea, measles, malaria and infections during infancy)? [...] I come to think of Sven Lindqvists bok, Terra Nullius, that I read about a year ago. It was about the rich countries' debt in relation to the colonial conquest of the current poor parts of the world and how we repress both the memory of this as well as our remnant colonial ideas. [...] Already as children we share the prey and continue throughout our lives to live well on it. Those from whom it has been taken, for example banana plantation workers, have to sweat in hunger strikes under plastic sheeting while their kids eat what we leave at the restaurants and the workers themselves get sick from the pesticides that make our bananas cheaper. [...] In Sarec's 20-year anthology, social anthropologist Gudrun Dahl and historian Birgitta Odén describe the relationship between knowledge and Sweden's road from poverty to prosperity. [...] The authors conclude by maintaining that the extreme inequality existing between rich and poor countries risks making scientific knowledge acquire a much larger argumentational value than the locally acquired, practical knowledges of farmers, fishermen, workers and many others. This can be prevented but in order for this to happen, a more active, self-critical and epistemologically aware research which focuses on its own foundations and has the ability to search for insights in a frequently diffuse practical experience that does not provide prestige. ${ }^{332}$

- Åke Thörn, physician and researcher

Who gives reality its name? About research aid and blind spots (2008)

Thörn worked as a physician and researcher in Nicaragua for several years as part of Sarec-financed efforts to contribute to capacity building within healthcare research. The book is not primarily academically oriented, but it is nonetheless very relevant in this context. Thörn expresses frustration with the fact that known solutions to problems of development and health are not applied to the extent that they could be. It is also a plea for recognition of the existence of a variety of important knowledges; scientific knowledge is not the only valid way to understanding our surrounding. The quote could be seen as another, more personal, illustration of the complexities involved in aiding science.

The literature on issues surrounding research aid is abundant and also very diverse in terms of where it comes from and what perspectives and approaches are used. If one adds the literature on the broader theme of the role of universities, science and/or

332 Thörn, Å. (2008). Vem ger verkligheten namn? Om forskningsbistånd och blinda fläckar, Hjalmarsson och Högberg. pp191-192 (English translation of title: Who gives reality its name? About research aid and blind spots). 
technology in development - the list grows considerably. The phenomenon of research aid is influenced by both research politics and aid politics and is consequently studied in several fields such as different branches of economics, politics, management, policy, environmental science, health sciences and agriculture. There are also a great number of studies produced or commissioned by aid organizations (some written by researchers, some by policymakers and some by both). ${ }^{333}$ Given that I have framed this as a contribution to science and technology studies (STS), it is worth underlining that this kind of empirical focus is still relatively marginal. Though many studies within STS involve the study of different aspects of science and/or technology in low-income countries, ${ }^{334}$ studies related to the history of aid are not common. The links to STS in this study are therefore more prominent on a general level and in my use of theory.

The purpose of this chapter is to present an overview of the research of relevance to my area of study. ${ }^{335}$ Given the cross- and interdisciplinary nature of research aid - I have chosen to cast a broad net in this case. The aim is to provide a picture of both practical and more theoretical research on the object of study. I try to be clear in contextualizing what kind of publication I am referring to, and why, but the diversity of the material used in this chapter illustrates the complexity of the field. The questions in focus in the studies vary but there are also several common themes that can be identified. Some studies focus on aid-related capacity building cooperation and others on standard research partnerships; some are based on country or case studies and others are more

\footnotetext{
${ }^{333}$ I am referring mainly to documents by large and influential donor organizations such as the World Bank, the United Nations and some other smaller donors. These are a kind of hybrid to me - sometimes the documents are clearly a part of my material - or the wider object of study anyway - and sometimes they fall under the category "previous research." Whether or not a publication is peer-reviewed could be a way of separating the two, but this is not necessarily easy to assess (the organizations publish a lot in all kinds of formats), so I have instead tried to be clear with presenting the actors behind such reports, position papers or evaluations. ${ }^{334}$ Such as Ynalvez, M. A. and W. M. Shrum (2009). "International Graduate Science Training and Scientific Collaboration." International Sociology 24(6): 870-901., Ampofo, A. A., J. Beoku-Betts, et al. (2004). "Women's and Gender Studies in English-Speaking Sub-Saharan Africa. A Review of Research in the Social Sciences." Gender \& Society 18(6): 685-714., Duque, R. B., M. Ynalvez, et al. (2005). "Collaboration Paradox: Scientific Productivity, the Internet, and Problems of Research in Developing Areas." Social Studies of Science 35(5): 755-785., Seth, S. (2009). "Putting knowledge in its place: science, colonialism, and the postcolonial." Postcolonial Studies 12(4): 373-388, Ordóñez-Matamoros, G., S. E. Cozzens, et al. (2011). North-South and South-South Research Collaboration: What Differences Does It Make For Developing Countries? - The Case of Colombia. Atlanta Conference on Science and Innovation Policy, Shepherd, C. J. (2006). "From In Vitro to In Situ: On the Precarious Extension of Agricultural Science in the Indigenous "Third World'." Social Studies of Science 36(3): 399-426., Smith-Doerr, L. A. and J. B. Croissant (2011). "A feminist approach to university-industry relations: Integrating theories of gender, knowledge, and capital." Journal of Women and Minorities in Science and Engineering 17(3): 251-269., Philip, K., L. Irani, et al. (2012). "Postcolonial computing - a tactical survey." Science Technology Human Values 37(1): 3-29., and de Laet, M. and A.-M. Mol (2000). "The Zimbabwe Bush Pump: Mechanics of a Fluid Technology." Social Studies of Science 30(2): 225-263

335 Parts of this chapter have been published in an article I wrote on the topic of tensions and dilemmas within research aid: Brodén, V. (2012). "Aiding research capacity for development: tensions and dilemmas." International Journal of Contemporary Sociology 49(1): 117-144.
} 
theoretical. My impression is that there are not many studies that focus specifically on the contents of policies. Furthermore, there are several studies on aid policy, but very few that address specifically research aid policy.

A glimpse into the debate on foreign aid in general is a good place to start in order to understand the context of the Swedish case. I will then present some of the research that has been done on Swedish aid. Last but not least, I will account for some of the studies that have investigated research aid - both internationally and in the case of Sarec specifically.

\section{Foreign aid: wanted dead or alive? Questioning aid efficiency}

The discussion about what good aid is has been going on since its beginning, but during the 1990's the critique got particularly intense, ${ }^{336}$ and the debate has continued during the 2000 's. ${ }^{337}$ It is important to criticize aid since "the business of aid" can impact countries' long-term development significantly, according to policy researcher Nancy Birdsall. As a way to problematize the policy and practice of both bilateral and international aid actors, she presents "seven deadly sins" committed by donors: impatience (with institution building); envy (collusion and coordination failure); ignorance (failure to evaluate); pride (failure to exit), sloth (pretending participation is sufficient for ownership), greed (unreliable as well as stingy transfers) and foolishness (underfunding of global and regional public goods). ${ }^{338}$

Birdsall envisions "fixes" for these sins as well, such as: the adoption of longer-term commitments (seven years and longer) tied with incremental financing tied to explicit goals concerning increases in capacity; a revival in support to long-term education and training; increased concentration of resources to fewer countries or to multilateral efforts to avoid inefficient donor overload; more independent and international evaluations of aid actors; and donors basing activities more on the proposals from low-income countries instead of shaping programs themselves. ${ }^{339}$ These suggestions represent a reformist approach in the sense that the current system is seen to have flaws but that that same system can be used to solve the problems.

Other critical voices maintain that low-income countries would be better off without foreign aid altogether. This is one of the central claims in the book "Dead Aid" by economist Dambisa Moyo. She maintains that foreign aid tends to hinder good governance and trap African countries in dependency rather than enable growth and development,

\footnotetext{
336 See for example the discussion about the three waves of aid literature by Hansen, H. and F. Tarp (2000). "Aid Effectiveness Disputed." Journal of International Development 12: 375-398. 337 Those actively involved in the aid efficiency debate during the last couple of decades are mostly economists, some of the most well-known participants being Paul Collier, William Easterly, Jeffrey Sachs and Joseph Stiglitz. Others who are frequently cited on the subject include Craig Burnside and David Dollar.

${ }^{338}$ Birdsall, N. (2008). Seven Deadly Sins: Reflections on Donor Failings. Reinventing Foreign Aid. W. Easterly, MIT Press. p516

339 Ibid. pp519-540
} 
and suggests that aid should be phased out within a period of 5 to 10 years. ${ }^{340}$ The book attracted a great amount of attention - both support and critique. ${ }^{341}$ Moyo is not alone in questioning the effectiveness of aid. There are opinions all across the spectrum between "aid is useless" and "aid is great"; the topic of aid is no doubt controversial. ${ }^{342}$

The answers to whether or not aid "works" differ depending on which kinds of programs and donors that are analyzed, what time periods are studied, and not least how one defines and measures development. Is development economic growth, poverty reduction, both, or something else? How does one measure development? Development is often equated with economic growth, and the assumption seems to be that economic growth will automatically lead to poverty reduction. Nevertheless, since economic growth is so often discussed in conjunction with aid, a glimpse into what has been said about the links is an interesting place to start. It is even more interesting when debating the question "do economists make markets?", as sociology researchers Donald MacKenzie, Fabian Muniesa and Lucia Siu do in their anthology on the performativity of economic theory:

To speak at a high level of generality about the "effects" of economics on economies is a dangerous short-cut. Are those effects direct? Of what kind are they? Economics (both in the broad sense of the wide variety of specialties and technical forms of knowledge deployed in markets and also in the narrower sense of the academic discipline) can relate to and act upon its objects in many ways: by observing them, by measuring them, by predicting them, by providing theories to explain them or instruments to regulate them, by spreading some functional technique about them (or just some suggestive vocabulary to deal with them), buy designing them in a laboratory, by inventing them, and so on. And, symmetrically, the "object" of economics (the many economic entities that are taken into account by economics) can react to this science in many ways: by mimicking it, by using it for profit, by believing it (and possibly by funding it!), by inadvertently operating it, but also by fighting it, by undermining its validity, and so on. Such interactions can change how resources are produced, organized, exchanged and consumed. ${ }^{343}$

In other words, economics is not just a matter of objectively observing and describing reality. Similarly to the ideas by Andy Stirling in the opening chapter ("our imaginations

\footnotetext{
${ }^{340}$ Moyo, D. (2009). Dead Aid. Why Aid Is Not Working and How There Is a Better Way for Africa, Farrar, Straus and Giroux. pp xix, 76\&143

${ }^{341}$ See for example an article published by Sida on Moyo's claims, including references to some reviews, Sida. (2009). "Zambiska Dambisa Moyo utmanar biståndet." Retrieved January, 2011, from http://www.sida.se/Svenska/Nyhetsarkiv/2009/Maj/Zambiska-Dambisa-Moyo-utmanarbistandet/.

${ }^{342}$ Some are critical of the idea of international development in general, like sociology and development studies researcher Henry Veltmeyer. See for example Veltmeyer, H. (2005). "Development as Globalization as Imperialism." Canadian Journal of Development Studies xxxvi(1).

343 MacKenzie, D., F. Muniesa, et al., Eds. (2007). Do Economists Make Markets? On the Performativity of Economics, Princeton University Press.
} 
of progress are [...] a principal factor conditioning the ways our progress actually unfolds" ${ }^{344}$ ), ideas about how the economy works are significant in constructing that very economy.

Back to the debate on aid efficiency. There is no systematic evidence to support the idea that increased economic growth (measured in BNP) leads to poverty reduction or more equitable distribution of resources in a country. A report from 2001 by economist Jakob Svensson claims that as a result of this, aid-related research has been focused on exploring the connection between foreign aid and economic growth. ${ }^{345}$ The connections between foreign aid and growth, however, remain difficult to prove. Despite this, Svensson maintains that it is reasonable to measure the effects of aid by looking at both economic growth and poverty reduction.

According to a study by economists Craig Burnside and David Dollar the relationship between foreign aid and growth depends on the quality and robustness of institutions and policies (such as property rights and rule of law). ${ }^{346}$ Svensson argues along similar lines, suggesting that macroeconomic stability is a sign of the "recipient country's" policy preferences which in turn may be indicative of the government's economic values and priorities. These values and priorities impact the effect of foreign aid as improved political rights and democratic institutions increase the accountability of political power. ${ }^{347} \mathrm{He}$ claims that countries which are lacking in political rights show a weaker correlation between foreign aid and growth. Furthermore, Svensson points out that the importance of macroeconomic balance appears to be greater when the period of study is relatively short (four years), but if the period is extended to ten years, the level of political rights and democracy are more significant to the relationship between foreign aid and growth. He concludes that though foreign aid and growth tend to be positively correlated in certain countries, the effects on poverty reduction and long-term growth appear to generally be very low. ${ }^{348}$

Based on the findings discussed above it seems like foreign aid can contribute to economic growth only in countries that do not really need aid. Burnside and Dollar claim that robust and high-quality institutions and policies are a prerequisite for aid to contribute to economic growth. They also encourage aid organizations to continue the trend of directing funds systematically to countries with strong institutions and

\footnotetext{
${ }^{344}$ Stirling, A. (2009). "Direction, Distribution and Diversity! Pluralising Progress in Innovation, Sustainability and Development." The STEPS Centre.p5

${ }^{345}$ Svensson, J. (2001). Foreign Aid: Does it Work? Can it Work? Report to the Committee on Sweden's Policy for Global Development (Globkom). p7

${ }^{346}$ Burnside, C. and D. Dollar (2004). Aid, Policies, and Growth: Revisiting the Evidence, World Bank Policy Research Working Paper 3251. pp3\&6. See also Burnside, C. and D. Dollar (2000). "Aid, Policies, and Growth." The American Economic Review 90(4).

${ }^{347}$ Svensson, J. (1999). "Aid, Growth and Democracy." Economics and Politics 11(3). pp276 \& Svensson, J. (2001). Foreign Aid: Does it Work? Can it Work? Report to the Committee on Sweden's Policy for Global Development (Globkom). p8 348 Svensson, J. (2001). Foreign Aid: Does it Work? Can it Work? Report to the Committee on Sweden's Policy for Global Development (Globkom). p9
} 
policies. ${ }^{349}$ Aid, however, is sometimes focused on building stronger institutions and policies, and the goals can encompass more than economic growth. One could also argue, latching onto the arguments of Burnside and Dollar, that aid to building institutional capacity could contribute to more effective aid and economic growth. Certain aid could then work in countries with "weak" institutions and policies. Of course one might question whether aid can successfully contribute to institutional capacity building, but my point is that it might have unfortunate consequences to equate successful aid with just economic growth and choosing countries based on such generalizing factors. ${ }^{350}$

Svensson raises this question as well, highlighting the fact that donors often have other types of aims, including poverty reduction, and poverty is defined by factors that are difficult to control in the short-run. ${ }^{351}$ While the unclear links between aid and economic growth could be interpreted as failure, the flows of foreign aid are in practice largely determined by strategic and political considerations; ${ }^{352}$ hence, he suggests, the efficiency of aid should be measured by using other indicators. ${ }^{353}$ Svensson suggests among other things improved donor coordination and financial commitments based more on specific countries' situations, needs, and "performance." He is in favour of creating a kind of competition between "recipient" countries, and recommends a larger focus on transfer of "ideas" rather than money. ${ }^{354}$

Many researchers have analyzed the claims of Burnside and Dollar, questioning their models and adding a variety of different types of factors, kinds of aid and contexts. To make a long story short, aid seems to be able to work even in countries with so-called unfavourable policy environments even though there is room for much improvement in the way aid works. ${ }^{355}$ Political economists Steven Radelet, Michael Clemens, and Rikhil Bhavnani distinguish between humanitarian, early-impact ${ }^{356}$ and

349 Burnside, C. and D. Dollar (2000). "Aid, Policies, and Growth." The American Economic Review 90(4). p21

350 For critique of Burnside and Dollar see for example Cogneau, D. and J.-D. Naudet (2005).

"Who Deserves Aid? Equality of Opportunity, International Aid and Poverty Reduction." World Development 35(1).

351 Svensson, J. (2001). Foreign Aid: Does it Work? Can it Work? Report to the Committee on Sweden's Policy for Global Development (Globkom). p13

352 See also the discussion on reasons for providing aid further on in this chapter. Explicit vs.

"unwritten" goals.

353 Svensson, J. (2001). Foreign Aid: Does it Work? Can it Work? Report to the Committee on Sweden's Policy for Global Development (Globkom). pp10-11. See also Radelet, S., M. Clemens, et al. (2004). Counting Chickens when they hatch: The short-term effect of aid on growth Working paper \#44, Center for Global Development. p1

${ }^{354}$ Svensson, J. (2001). Foreign Aid: Does it Work? Can it Work? Report to the Committee on Sweden's Policy for Global Development (Globkom). pp16-19

355 For a summary on the aid-efficiency debate see Loots, E. (2006). "Aid and Development in Africa: The Debate, The Challenge and The Way Forward." South African Journal of Economics 74(3). See also Hansen, H. and F. Tarp (2000). "Aid Effectiveness Disputed." Journal of International Development 12: 375-398. and Arndt, C., S. Jones, et al. (2009). Aid and Growth Have We Come Full Circle? . Discussion Paper No 2009/05, United Nations University World Institute for Development Economics Research.

356 Which is more likely to have effect within a four-year period, such as infrastructure, budget support and industry investments 
late-impact aid, where late-impact aid (such as environmental protection, democratic reform or education) is of the kind that might impact growth but likely in an indirect way and over longer periods of time. ${ }^{357}$ They found that aid has a positive effect on growth regardless of the strength of institutions, even though early-impact aid has somewhat better effect on growth in countries with stronger institutions and higher life expectancy. ${ }^{358}$

Others have focused more directly on the effect of aid on poverty rather than economic growth. According to economists Paul Mosley, John Hudson and Arjan Verschoor poverty reduction has since the end of the 1990's replaced economic growth as the main goal of development efforts in low-income countries, resulting in donors changing the way they select collaborating countries. ${ }^{359}$ Instead of demanding policy changes, Mosley et al maintain that donors now choose to collaborate with countries which already have "desirable" policy conditions. They suggest increased attention to corruption, inequality and composition of public expenditure in order to improve aid effectiveness - a new kind of conditionality where several levels of commitment can be made to countries rather than deciding aid or no aid. ${ }^{360}$

What the verdict is on the link between aid and development clearly has to do with what definition of development one has and what factors that are taken into account - why and how. There are many both explicit and implicit reasons for engaging in aid, and what might seem economically sound may not be politically sound, and so on. The bearing of these findings on my own study is that it helps place research aid in a wider context. Research aid, according to the discussion above, would fit under in the category "late-impact aid" which is deemed likely to contribute to growth but in an indirect way and over a long period of time. Research aid is nonetheless considered to be able to have faster impact as well, something which I will return to further on in this chapter.

\section{Research aid: some general trends in the literature}

Studies on research aid are found in various different disciplines, under different names and with different concepts. ${ }^{361}$ It also covers slightly different kinds of cooperation, some under the umbrella of foreign aid and others not. ${ }^{362}$ This has been a challenge because the field is diverse and many of the authors do not seem to know about each other even

${ }^{357}$ Radelet, S., M. Clemens, et al. (2004). Counting Chickens when they hatch: The short-term effect of aid on growth Working paper \#44, Center for Global Development.. See also Radelet, S., M. Clemens, et al. (2005). Aid and Growth. Finance and Development, IMF. 42.

${ }^{358}$ Radelet, S., M. Clemens, et al. (2004). Counting Chickens when they hatch: The short-term effect of aid on growth Working paper \#44, Center for Global Development. pp1-2

${ }^{359}$ Mosley, P., J. Hudson, et al. (2004). "Aid, Poverty Reduction and the New Conditionality." The Economic Journal 114. pF217

360 Ibid. pF219

${ }^{361}$ It can be called for example university collaboration, capacity building in research, research cooperation, North-South research collaboration, science and technology cooperation, research and technology for development and so on.

362 This is reflective of what was discussed under "background" in chapter 1 - there are various kinds of actors involved in promoting research cooperation with different purposes. 
though they are writing about similar things. ${ }^{363}$ There are some books on the subject, but the bulk of what I found consists of journal articles and conference papers or proceedings.

Development studies researcher Megan Bradley conducted a literature review on the area of North-South research partnerships, surveying around 150 texts available in 2007. According to Bradley, the literature has discussed ways to make research cooperation more beneficial to low-income countries for many decades. ${ }^{364}$ Asymmetry between collaborating countries has been identified as the main problem - an asymmetry expressed by for example unequal salaries, unequal access to information and training or control over choice of partners, research agendas and project administration. ${ }^{365}$ She claims that the literature indicates that researchers from both high-income and low-income countries are seeing partnerships more as mutually beneficial. ${ }^{366}$ Furthermore, she maintains that the outputs of these partnerships considered valuable are no longer limited to co-authored papers in journals, but that capacity building and policy effects are considered important indicators of success as well. ${ }^{367}$ At the same time, studies consistently show that high-income country partners benefit the most. ${ }^{368}$ Bradley suggests that the term collaboration often covers a great number of activities other than joint publication (like capacity-building partnerships and formal or informal research networks), and that these activities are not studied enough (as opposed to bibliometric analyses of global publishing trends for example). ${ }^{369}$

There is a growing pro-interdisciplinarity trend among donors, not least evident during the 1990's and 2000's, though this interdisciplinarity seems difficult to realize in practice. Despite the fact that there is a growing interest in studying North-South partnerships, seems to be little cooperation between researchers in different disciplines. ${ }^{370}$ Nevertheless, studies of research cooperation of different kinds are being done, and one of the theoretical approaches that have become popular in recent decades is systems of innovation - and this seems to be the case with both low-income and high-

\footnotetext{
${ }^{363}$ References between authors are fewer than I expected. This has also been pointed out in the literature review by Bradley (2007), see below.

364 According to Bradley, one of the first concrete articles on making development research more equal was one by Amin, S. (1975). "New Forms of Collaboration in Development Research and Training." International Social Science Journal XXVII(4): 790 - 795.

${ }^{365}$ Bradley, M. (2007). On the agenda: North-South research partnerships and agenda-setting processes International Development Research Centre (IDRC). pp1,2\&16. See also Menon, V. and K. N. Nair (2002). Capacity Building for Demand-led Research: Issues and Priorities Maastricht: European Centre for Development Policy Management. p14

366 Bradley, M. (2007). On the agenda: North-South research partnerships and agenda-setting processes International Development Research Centre (IDRC). p2

367 Ibid. pp2 \&10

368 Ibid.pp19\&29

${ }^{369}$ Ibid. p13

370 Health and agricultural sciences are two examples of areas where partnerships and cooperation have been (and are) many (including studies about this cooperation), yet interdisciplinary dialogue on the issues does not seem to be widespread (see Bradley pp2, 10 \& 27)
} 
income country researchers. Interest in "demand-led research" has also been on the rise. ${ }^{371}$

Actors that Bradley considers underrepresented in the literature about research partnerships and research aid are research councils, students, and publishers for example. ${ }^{372}$ Underrepresented actors are something I have thought about as I have worked through my material, not least concerning students and the way that higher education and research are handled very much as separate policy areas. Increased research capacity is seen as contributing to the quality of higher education through the production of more highly-educated and up-to-date university teachers - but the fact that universities in many low-income countries have a lot more students and much fewer teachers than in high-income countries is not discussed to the extent that I expected.

Following up on some of Bradley's findings above, I will now present what I consider to be the main tensions in research aid as portrayed by the previous research I have taken part of.

\section{Unclear links and assumptions}

Tying back to the first pages of this chapter, one contentious question concerns how increased research capacity is seen to contribute to poverty reduction. ${ }^{373}$ The consensus seems to be that links do exist, but that they are more often considered indirect than direct. ${ }^{374}$ There is no "conclusive" evidence that increased capacity in science and technology in low-income countries will significantly contribute to economic growth for example, but since this has been the case in high-income countries, the conclusion seems to be that one could reasonably expect a similar development in low-income countries. A World Bank report from 2001 states: "Despite the lack of a theoretical or quantitative link between science and technology investment and development in developing or underdeveloped countries, many policymakers assume that benefits will accrue from such investments." 375

What kind of research leads to development - and what kind of development? This question is often tied to a discussion about what the role of universities is in society and the economy, and how knowledge is produced and disseminated. For instance, many texts (both policy-related and academic) reject the

\footnotetext{
${ }^{371}$ Bradley, M. (2007). On the agenda: North-South research partnerships and agenda-setting processes International Development Research Centre (IDRC). p. 11-12

372 Ibid. p6

373 See for example Banzon Bautista, M. C. R., L. Velho, et al. (2001 ). Comparative study of the impacts of donor-initiated programmes on research capacity in the South The Hague, Ministry of Foreign Affairs/Directorate-General for Development

Cooperation, the Netherlands p18

${ }^{374}$ See for example Weiler, H. N., S. Guri-Rosenblit, et al. (2006). Universities as Centres of Research and Knowledge Creation: An Endangered Species? Summary report from Colloquium on Research and Higher Education UNESCO. p14

375 Wagner, C. S., I. T. Brahmakulam, et al. (2001). Science and Technology Collaboration:

Building Capacity in Developing Countries?, The World Bank. p9
} 
linear model of innovation in favour of other theories of knowledge production such as Triple Helix, Systems of Innovation or Mode 1 and 2.376

These ideas about how science works or should work have clear effects on research policies and those that study them as well. Policy researcher Lea Velho uses the Mode 1/Mode 2 concepts to question the effects that research aid has on low-income country development and poverty reduction. ${ }^{377}$ More specifically, she claims that donors focus too much on individual capacity building. The training of individual scientists is not an effective enough method for building research capacity nor of contributing to development or poverty reduction, not least because in its current form it implies long periods of solitary work. According to Velho, this kind of method reflects an outdated, linear view of knowledge production and innovation. She calls for more systems-based strategies for research capacity building along the lines of Mode 2,378 where more effort is placed on teamwork and creating links between universities and other actors in society in order to for example increase the usability of research, and implement results faster. Nair and Menon agree with her, claiming that a mode 2 approach is likely to make support to building research capacity more demand-led. ${ }^{379}$ I will return to Velho further down, as her study is based on Sarec-supported cooperation.

\section{Conflicting goals and agendas}

According to an article by policy researcher Leo Van Audenhove, there has been a trend among research aid actors of moving away from aid to individual projects and focus on specific academic areas to broader support for institutional development more clearly based on specific low-income country contexts and priorities, including increased focus on development relevance and impact. ${ }^{380} \mathrm{He}$ suggests that this shift - initiated by a number of donors (including Sweden) in the late 1980's and early 1990's ${ }^{381}$ - reflects an ambition to find more appropriate models for cooperation in recognition of the fact that academic cooperation alone cannot build research capacity. ${ }^{382} \mathrm{He}$ maintains, however, that the shift also creates some dilemmas. The national aid agencies in high-income countries often provide support to research capacity building with development relevance in both the donor country and the low-income country. In many cases, both

\footnotetext{
376 Embedded in the more systemic theoretical perspectives is a different view of the role of technology in economic growth. The linear model of innovation is often associated with neoclassical economic models, which in turn have been criticized for black-boxing technology.

377 Se for example Velho, L. (2006). Building a critical mass of researchers in the least developed countries: new challenges. Science and Technology Policy for Development, Dialogues at the Interface. L. Box and R. Engelhard, Anthem Press.

378 For a detailed discussion on this see ibid. pp2-8

379 Menon, V. and K. N. Nair (2002). Capacity Building for Demand-led Research: Issues and Priorities Maastricht: European Centre for Development Policy Management. p6

380 van Audenove, L. (1998). "Development cooperation and linkages in higher education: Key issues concerning policy and organisation." International Review of Education 44 (5/6). p533 381 The article by Audenhove (1998) is based on a study of the research aid agencies of Canada, the Netherlands, Norway and Sweden.

382 van Audenove, L. (1998). "Development cooperation and linkages in higher education: Key issues concerning policy and organisation." International Review of Education 44 (5/6). p537
} 
academic cooperation and development cooperation (aimed at building research capacity) are pursued within the same program. Van Audenhove considers this to be problematic because the universities involved are often better equipped for academic cooperation than they are for development cooperation. ${ }^{383}$

This can be related to the discussion about the difference between conducting development-relevant research versus contributing to building research capacity in low-income countries. Actors such as universities, aid agencies, private sector actors, and governments have different views on what research activities should be prioritized. Given the many changes that universities have undergone during the last few decades, these views are possibly even more diverse. To what extent does the increased focus on cooperation with private sector actors affect the autonomy of research for example? The literature has to a large extent concerned universities in high- and middleincome countries, but also has relevance in low-income countries, not least given the increased presence of international actors, both public and private.

Krishna, Waast, and Gaillard argue that economic globalization - in the shape of for example increased presence of multinational enterprise (including the establishment of industrial R\&D) and higher foreign direct investment has influenced science structures in low-income countries. They argue that the presence of business actors in combination with the relatively low levels of national funding for research in low-income countries is contributing among other things to a type of internal brain drain and a change from "science as public good" to "science as market good."384

Brundenius et al raise similar concerns, maintaining that it is a challenge for universities that globalization processes push them to become more and more active internationally at the same time as they are expected to contribute more to development in their national contexts. ${ }^{385}$

The issue of inequality is the basis for a majority of the tensions. All efforts on the part of high-income countries to collaborate and cooperate with low-income countries to achieve development and poverty reduction can be questioned given the unequal footing between high-income countries and low-income countries. How much power do low-income countries have in steering the development agenda for example? Arriving at "national" or "local" priorities is not always a straightforward process. ${ }^{386}$ According to Bradley, the issue of inequality can result in problems when negotiation research agendas:

\footnotetext{
383 Ibid. pp533 \& 538

${ }^{384}$ Krishna, V. V., R. Waast, et al. (2002). "The Changing Structure of Science in Developing Countries." Science, Technology and Society 5(2). p211-213

385 Brundenius, C., B.-Å. Lundvall, et al. (2009). The role of universities in innovation systems in developing countries: Developmental University Systems - Empirical, Analytical and Normative Perspectives. Handbook of Innovation Systems and Developing Countries - Building Domestic Capabilities in a Global Setting. B.-Å. Lundvall, K. J. Joseph and C. e. Chaminade, Edward Elgar Publishing. pp311 \& 326

${ }^{386}$ See for example van de Sande, T. (2006). Priority Setting in Research For Development: A Donor Perspective. Science and Technology Policy for Development: Dialogues at the Interface. L. Box and R. Engelhard, Anthem Press. pp151-152
} 
Advocates of North-South research partnerships suggest that they are efficient, intellectually enriching, and conducive to capacity building. Yet veterans of NorthSouth research partnerships attest to a more complex reality, shaped first and foremost by the fact that partnering is often the only way for Southern researchers to access funding. The agenda-setting process represents a formidable obstacle for many development research partnerships. The literature on North-South research cooperation often laments the continued domination of collaborative agendas by the interests of Northern donors and scholars, and almost invariably calls for more equitable Southern engagement in agenda-setting processes. ... even innovative funding strategies cannot resolve all of the tensions that characterise collaborative agenda-setting processes. ${ }^{387}$

She maintains that research capacity is very complex, and that though research partnerships can contribute to capacity building, they are not enough. Similar to the conclusions of van Audenhove, Bradley's research illustrates the dilemma of combining the goal to achieve development goals with processes of building research capacity. Aid actors generally maintain that adequate research capacity is necessary for a country to be able to effectively address the country's present and future challenges - regardless of whether the challenges are directly relevant to international or high-income country development goals. At the same time, the support is conditioned in a variety of ways in order to match for example the foreign aid policy of a donor country. This is not sustainable, maintains chemistry professor and science and technology expert Erik W. Thulstrup in an article about research capacity building from 1998.388 According to Thulstrup, the reason why technologies so often fail in transfers to low-income countries is because national research capacity is not strong enough. In order for low-income countries to make efficient use of various technologies, he argues, research cannot be so driven by donors. Donor priorities focus on traditional areas like tropical health, tropical agriculture and development studies, whereas the needs are much wider. Basic sciences, engineering and management are examples of areas which Thulstrup maintains should be developed. ${ }^{389}$

\section{Mutually beneficial cooperation or neocolonial science?}

There is a substantial amount of discussion among researchers as well as development practitioners concerning how research-aid is done best in order to contribute to sustainable research capacity in low-income countries. Some are sceptical to altruistic rhetoric in development policies (such as that surrounding 'capacity'), questioning the reasons why high-income countries engage in development cooperation. Others see it as reflective of good intentions as well as recognition of the complexity of development

\footnotetext{
387 Bradley, M. (2008). "On the agenda: North-South research partnerships and agenda-setting processes." Development in Practice 8(8). pp673-674

388 Who has conducted a number of evaluations of Sarec.

389 Thulstrup, E., W. (1998). "Evaluation of Research Capacity Building in the Third World."

Knowledge, Technology \& Policy 10(4): 90-101. pp91-92
} 
processes. The discussions concern different views on for example what development is, how knowledge relates to development, what theories of development and of knowledge production underlie efforts in research aid, and what the role of universities is (or should be) in society and the economy. There exist many levels of tension between the idea of foreign aid based on solidarity, altruism, and poor countries' interests versus strategic and profit-driven activities designed to "conquer" markets. ${ }^{390}$

Regardless of whether the forms for cooperation are foreign aid-based or not, the inequality between high-income countries and low-income countries is seen to create problems. Though some global gaps are slowly closing and joint challenges demand increased international cooperation, one may question whether the practice of research aid paves the way for a sort of neo-colonial science. As far as research partnerships go, the terms for cooperation have been - and remain - more or less equal depending on the methods used. Exchanges might be explicitly or implicitly based more on priorities and needs of the university with the most resources. Costello and Zumla give some examples of unequal methods of research cooperation:

- Postal research - high-income country researchers request low-income country colleagues to supply them with data

- Parachute research - high-income country researchers travel to low-income countries for short periods of time and collect data. Results of both types of research are often published with minimal representation of low-income country input.

- Annexed sites for field research, led and managed by expatriate staff. Often successful but contributes to "brain drain" 391

Costello and Zumla claim that these methods can generally be classified as semicolonial, ${ }^{392}$ since they benefit high-income country researchers while they contribute little or nothing to the research capacity of the low-income country. Altbach argues along similar lines concerning power and influence of the low-income countries, and suggests that the development can be considered a form of 'neocolonialism':

We are now in a new era of power and influence. Politics and ideology have taken a subordinate role to profits and market-driven policies. Now, multinational corporations, media conglomerates, and even a few leading universities can be seen

\footnotetext{
${ }^{390}$ See for example Berthelemy, J.-C. (2005). Bilateral donor's interest vs. recipients' development motives in aid allocation: do all donors behave the same ? The Political Economy of Aid. Hamburg p2

391 Costello, A. and A. Zumla (2000). "Moving to research partnerships in developing developing countries." British Medical Journal (BMJ) 321(September): 827-829. p827. For an extensive discussion of some other research partnership models, see for example Ofori-Adjei, D. and J. Gyapong (2007). A Developing Country Perspective on International Research Partnerships on Health, Centre for Tropical Clinical Pharmacology, University of Ghana Medical School College of Health Sciences, Accra, Ghana Health Research Unit, Ghana Health Service. 392 Costello, A. and A. Zumla (2000). "Moving to research partnerships in developing developing countries." British Medical Journal (BMJ) 321(September): 827-829. pp827-828
} 
as the new neocolonists-seeking to dominate not for ideological or political reasons but rather for commercial gain. ${ }^{393}$

Altbach suggests that colonialism has merely taken on new forms, acquiring stronger profit-seeking mechanisms. The power and resources of high-income countries in essence leads to low-income country universities having very few options but to for example participate in exchanges and collaboration with high-income country actors if they want access to the global scientific playing field. Altbach maintains that there is a problem with structural dependency and also discusses for example the brain drain of students and researchers from "South to North." 394 In another article, he states that there will always be a scientific core and periphery - and that the industrialized countries are likely to remain the core for a while. ${ }^{395}$ His critique concerning the new face of colonialism is echoed by Xie Shaobo:

Formal independence for colonized countries has rarely meant the end of the First World's hegemony [...] rather, Westerners, after their withdrawal from these countries, continued to rule [...] morally and intellectually. Neocolonialism emerges as a regeneration of colonialism through globally hegemonizing Western economy, technology and ideology. With its economic and technological superiority, Western culture is penetrating entire systems of values, attitudes, morality, institutions and more important, modes of production. This is the moment of neo-colonialism, which is the cultural logic of multinational capital. 396

Shaobo maintains that despite the cutting of formal colonial ties, moral and intellectual "rule" has continued, and increased, through the economic and technological dominance of high-income countries, which in turn is very much driven by capitalistic interests. Issues concerning the effect of capitalistic interests on foreign aid and development agendas can be found in many of the articles, and it is also discussed as problematic in relation to higher education and research. Sawyerr discusses this inequality issue from a similar, but slightly different, perspective, focusing on the "hegemony of modern knowledge:"

The rise and spread of the "knowledge society" in the developed countries has led to the hegemony of modern knowledge and its manifestations and has opened up

\footnotetext{
393 Altbach, P., G. (2004). "Globalization and the University: Myths and Realities in an Unequal World." Tertiary Education and Management(10:1).p6

394 Ibid. pp6-8

395 Altbach, P., G. (2007). "Peripheries and Centres: Research Universities in Developing

Countries." Higher Education Management and Policy 19(2): 106-130. p2

${ }^{396}$ Shaobo, X. (1997). "Rethinking the Problem of Postcolonialism." New Literary History 28(1):

7-19. In the quote, Shaobo refers to Edward Said (1993, Culture and Imperialism), Ella Shohat, (1992, Notes on the Postcolonial), and Abdul R. JanMohamed, (1985, The Economy of Manichean Allegory: The Function Racial Difference in Colonialist Literature)
} 
virtually all societies to increased pressure from global values, products, and services. ${ }^{397}$

Sawyerr maintains that while there are positive effects of the spread of modern knowledge - such as improvements in nutrition and knowledge about environmental protection - there are negative effects as well: tendencies of political and economic dominance by high-income countries and their institutions, culture homogenization, and threats to local knowledge. ${ }^{398}$ Sociology researcher Syed Farid Alatas concurs in much of this, stating that "control is indirect via international law, the power of major commercial banks, [and] the threat of military intervention by the superpowers" for example. ${ }^{399} \mathrm{He}$ draws parallels between economic dependence and academic dependence within the social sciences - maintaining that neo-colonialism continues in part due to the academic dependency. This dependence concerns everything from research agendas, theoretical perspectives, methodology, research training and higher education. 400

An example of the neo-colonial potential of research aid is presented by Dana $G$ Holland. ${ }^{401}$ She interviewed researchers in Malawi who discuss some of the dilemmas they face. One researcher highlights part of the problem with unequal partnerships:

Since the 1990s, we have been spending more and more of the limited time we have for research, on commissioned research for the sake of, you know, survival (laugh). So sometimes we have been undertaking research, a type of research for which we have limited expertise given the kind of training that most of us have, but we have no choice. We take them up for the sake of survival because that way we are able to access the money with which to improve the budget of the department, to buy computers, what we cannot get through the regular university budget. ${ }^{402}$

Holland concludes that there is a tension between Mode 1 and 2 science in that the Mode 2 emphasis on applicable results is not always compatible with the quality criteria associated with Mode 1. Pursuing both basic and applied sciences, not least context where research capacity is limited, can be difficult. ${ }^{403}$ In a similar discussion (though not specifically related to Mode 1 and 2) public health and biotechnology researcher Eva Harris maintains that scientific capacity building has to be more in tune with the needs of the developing country partners; “Clearly, 'parachute science', in which investigators from

\footnotetext{
${ }^{397}$ Sawyerr, A. (2004). "African Universities and the Challenge of Research Capacity Development1." Journal of Higher Education in Africa 2 (1): 213-242. p214 398 Ibid.

${ }^{399}$ Alatas, S. F. (2003). "Academic Dependency and a Global Division of Labour in the Social Sciences, Current Sociology, Vol.51." Current Sociology 51(6): 599-613. p602 400 Ibid. pp606-607

401 Whom also wrote a dissertation: Holland, D. G. (2006). Socializing knowledge: The production and circulation of social science in Malawi, 1964--2004, University of Pennsylvania. 402 Holland, D. G. (2009). "Between the Practical and the Academic: The Relation of Mode 1 and Mode 2 Knowledge Production in a Developing Country " Science, Technology and Human Values 34(5). p563 403 Ibid. pp568-569
} 
developed countries merely collect samples, return home and publish papers, is of no real use to scientists and citizens in developing countries." 404 Long-term support and research partnerships are necessary in order to build sustainable capacity, maintains Harris.

As exemplified above, time-frames are raised as an important factor in research aid. Reaching development goals and building capacity is according to several researchers as well as policymakers demands long-term endeavours and require efforts on many levels. At the same time, aid actors are criticized for having too many short-term research cooperation projects (or as expressed by several researchers: 'parachuting partners'). This is also discussed by a group of UK researchers:

There is often a tension between finding suitable interventions that can bring shorter-term and longer-term capacity building. Although short-term approaches may play some role in shaping long-term capacities, they may not be systemic, costeffective, or appropriate. [...] Supporting the correct mix of activities is crucial to building effective capacity [...] Short-term initiatives and activities must be understood in the context of longer-term institutional support and innovation. ${ }^{405}$

The authors maintain that though the time-factor is just one of many important ingredients, too many projects that aim to improve research capacity are short-term and isolated from other projects and actors, which according to them inhibits the learning process and limits their actual effect on capacity. ${ }^{406}$ Long-term cooperation is also, however, seen as increasing the risk for academic dependency, as discussed by Alatas. ${ }^{407}$

One might ask whether global problems (such as environmental challenges and threats to food or energy security) - which increasingly require international cooperation - are levelling the playing field between high-income countries and low-income countries in some sense. According to agricultural researcher Stig Enemark, it is important for highincome countries to recognize that there are mutual benefits to research cooperation between high-income countries and low-income countries:

It is important that such capacity building activities are seen as not only a key driver for societal development in the recipient countries, but also as a necessity for facilitating the building of relevant international capacity and institutional innovation in the donor countries. It is a process of mutual benefit for both recipient and donor countries. ${ }^{408}$

\footnotetext{
${ }^{404}$ Harris, E. (2004). Building scientific capacity in developing countries. EMBO reports VOL 5:1 7-11.p9

405 Chataway, J., J. Smith, et al. (2005). Partnerships and Building Capabilities for Science, Technology, Innovation and Development in Africa, The Open University, Research Centre on Innovation. Knowledge and Development. pp21-22

406 Ibid. p22

${ }^{407}$ See for example Alatas, S. F. (2003). "Academic Dependency and a Global Division of Labour in the Social Sciences, Current Sociology, Vol.51." Current Sociology 51(6): 599-613.

408 Enemark, S. (2005). Capacity Building for Higher Education in Developing Countries - A Part of the Western World University Portfolio? Capacity Building in Higher Education and Research on a Global Scale. Copenhagen UNESCO. p1
} 
Enemark also states that the role of high-income country universities in this process needs to be clearer, and suggests that in order for research cooperation to work better, there needs to be a national understanding among actors in the high-income countries (donor agencies, universities and education ministries) regarding the purpose and interests of all involved. ${ }^{409}$ Furthermore, efforts need to be based on "a national priority and a holistic historical analysis of the national system of higher education (in the lowincome country) and its contribution to social, economic and political development." 410

Having mapped out some of the tensions and dilemmas in the previous research, it becomes clear that as a field of study - it is diverse, complex and of interest to many actors. After a short comment Swedish aid in general, I will narrow in on studies that in some way concern the activities of Sarec.

\section{Research on Sarec}

There seems to be consensus concerning the idea that Swedish foreign aid has since its start consistently had a wider definition of development, with poverty reduction as the motivation for providing aid. Sweden has become known for large volumes of aid, untied and demand-sensitive, even emancipatory in its approaches. This does not mean that Sweden does not provide aid for other reasons than solidarity. Political science researcher Anna Brodin maintains in her doctoral thesis about development cooperation workers that the view of Sweden as a donor ("the darling of the third world") has changed since the introduction of the OECD. ${ }^{411}$ This view is echoed by Wolgemuth and Odén who state that Sweden has had solidarity as its lead motive since its beginnings and was running very much its own aid agenda - in international comparison - until at least the 1980's. ${ }^{412}$ They claim that the time after the end of the Cold War and the EU-expansion has seen Sweden become more of a mainstream donor:

A change in the perception of the role of Swedish aid has been evident in recent years. The basic element of trust between two sovereign states seems to have weakened as indicated by increasing demand for control measures. [...] The new results agenda, as described above, is a major feature of this new attitude. The more skeptical attitude towards partnership with governments has also meant that aid is channeled increasingly through non-governmental actors, in particular the private business sector in the partner countries. Thus, Swedish development cooperation seems to have become more supply-driven and less demand-driven; the influence of the receiving partner has been reduced while Swedish views and ideas of what is

\footnotetext{
${ }^{409}$ Ibid. pp1-2

410 Ibid. p2

411 Brodin, A. (2000). Getting politics right : democracy promotion as a new conflict issue in foreign aid policy Doctoral thesis, University of Gothenburg. pp35-37

${ }^{412}$ See for example Sogge, D. (2002). Give and Take? What's the Matter with Foreign Aid? , Zed Books. p78
} 
most suitable for the receiver are on the increase (Government Decision, 2013-0711, Development Today 2012-04-11). ${ }^{413}$

Plenty of well-intended policies have been written in recent years, but without adequate funds to go with them they remain without great effect maintain Wohlgemuth and Odén. Aid is now perceived more as "Swedish activities in foreign countries" rather than support to activities in partner countries. They are critical of this trend and maintain that it erodes sustainability of cooperation.414 A recent dissertation by Tomas Kjellkvist (former director at Sarec, 2008-2010) is also critical of how Swedish foreign aid has developed in the last two decades. His main research question asks in what way Swedish aid has enabled innovation through its policies and practices. ${ }^{415}$ Through studies of parliamentary records and state investigations he writes a history of Swedish aid, concluding that aid has become very abstract and policy-driven in the last decade:

The debt crisis and the end of the Cold War changed the aid goals in favor of democracy and human rights rather than economic growth and independence. Along with this change grew increasing demands on conditionality connected to Swedish aid. Work modalities changed to favor "policy aid" instead of material interventions. Knowledge and technology got a much more marginalized role under this regime. 416

Among other things, Kjellqvist maintains that the concept of capacity building has been reconfigured as a top-down approach, serving the interests of donors rather than lowincome countries. ${ }^{417}$ Kjellqvist's dissertation includes an account of Sarec, focused on describing its history as an organization and from the point of view of government documents. The study presents how political principals have acted to define and influence the direction of Sarec's organization and activities through parliamentary work.

Swedish research aid could somewhat ironically be said to be underresearched. Sida and or Sarec in relation to research aid is mentioned in quite a number of books, articles and reports but very few works focus solely or mainly on this, and it is worth mentioning that some of the publications are written by researchers who have also evaluated Sarec for example. There are a few researchers, however, who have looked a little bit closer. I will discuss both kinds of studies.

Among those that discuss Sarec in comparison to other donors is Van Audenhove, whose work I discussed above. In an article from 1998, he claimed that Sarec was among the "leading institutions in international discussions on higher education and

\footnotetext{
413 Odén, B. and L. Wohlgemuth (2013). Swedish Development Cooperation Policy in an International Perspective, School of Global Studies, University of Gothenburg. p60 ${ }^{414}$ Ibid. p64

${ }^{415}$ Kjellqvist, T. (2013). Biståndspolitikens motsägelser om kunskap och tekniköverföring - från konkret praktik till abstrakt policy. doctoral dissertation series, Blekinge Institute of Technology. p27

416 Ibid. p7

417 Ibid. p271
} 
development and play an emancipatory role towards Southern institutions of higher education and research." 418 The other institutions were the Canadian IDRC, the Dutch Nuffic and the Norwegian NORAD. ${ }^{419}$ He maintained that their emancipatory potential has had to do with for example the level of responsibility given to the low-income country partners. The more supply- or donor-driven, the less emancipatory. A working paper by Joanna Chataway et al from the Open University argues along similar lines and states that Sarec had a broad view of capacity and promoted low-income country ownership of the research agenda-setting:

SAREC's support has differed from other donors in one important respect. It has explicitly supported institutional development of research capabilities in African universities, and exhorted others to join it in coordinated support led by the local universities themselves [...] Sarec's decision not to emphasize research institutes, individual scientists outside the national research institutes, and NGO research units is made in an attempt to build longer-term research structures. The thinking is also linked to the idea that research institutions should also be key national cultural centres not short-term ways of responding to particular development problems - although much of the research supported is applied, problem-oriented and strategic. Thus, there is a move within even this university-centred approach in the direction of Mode 2.420

The authors maintain Sarec has focused clearly on universities in order to build long-term research structures but that they have started moving in the direction of Mode 2 science, where more actors (academic and non-academic) in a national setting are involved in the capacity building process. They also state:

The experiences of Sida-SAREC in supporting African universities as hybrid research and learning institutions illustrates that focus on support for the single best institution within a particular resource-poor setting can place universities within national systems of innovation. This approach provides short-term project support and also longer-term infrastructural program support, including library and ICTs, support for research management, laboratory development, and technician training. The model is one way of supporting the short-term within the context of the longer-term - as an institutional approach and potentially as part of a systemic approach. As such it is a much more flexible support system than much other project based, time boundaried bilateral support. ${ }^{421}$

\footnotetext{
${ }^{418}$ van Audenove, L. (1998). "Development cooperation and linkages in higher education: Key issues concerning policy and organisation." International Review of Education 44 (5/6). p542 ${ }^{419}$ See also Jones, N., M. Bailey, et al. (2007). Research capacity strengthening in Africa Trends, gaps and opportunities, Overseas Development Institute (ODI).

${ }_{420}$ Chataway, J., J. Smith, et al. (2005). Partnerships and Building Capabilities for Science, Technology, Innovation and Development in Africa, The Open University, Research Centre on Innovation. Knowledge and Development. pp10-11 ${ }^{421}$ Ibid. p22
} 
It appears unclear to me whether they consider the "Mode 2" entirely positive but the idea of envisioning universities as part of a bigger national system is portrayed in a fairly positive manner, as a win-win situation.

There are some more critical voices as well. Education researcher Jacques Gaillard paints a slightly different picture and discusses Sarec in an article about Tanzania and dependent science. He maintains that Sarec had been a very important donor in the area of research in Tanzania. The support modalities of the 1970's and 1980's, however, had in some ways inhibited independent identification of national research priorities. The project collaboration model, Gaillard states, had nonetheless strengthened the internationalization of Tanzanian science as well as Swedish development research capacity. The institutionally oriented university support is a more appropriate and demand-driven way to support research. ${ }^{422}$

Lea Velho (Campanas Uni, Brazil) published a set of articles between 2002 and 2006 about Sarec's support to research capacity at four public universities in Nicaragua. Though I do not classify evaluations as previous research, I looked at the Sidacommissioned evaluations concerning this specific case since Velho's critique so clearly related to my research questions. I was curious to see what kind of critique was voiced in the evaluations. Although this only refers to one country, and although I cannot account in detail for the extensive discussion I found, I will describe it briefly because I think it raises some interesting questions of relevance to my study.

Velho claims that while the policies of Sarec reflect a commendable, nonlinear, and systems-based view of capacity building - the cooperation in practice instead shows that the linear model (in 'Mode 1' style) has not been abandoned. ${ }^{423}$ She argues that the dominant focus on supporting the career development of individual scientists (attainment of MSc's and PhD's through sandwich program training for example) does not necessarily result in the kind of capacity that helps advance the development of Nicaragua. ${ }^{424}$ The concentration on the skills of individuals occurs at the cost of other aspects of capacity such as the links between researchers and other actors like civil society and industry. ${ }^{425}$ A Dutch government-commissioned evaluation a few years earlier by Velho, Kaplan and Bautista seemed to reach a slightly different conclusion:

The university-based programmes respond to the demand from local universities and society at large for academically qualified researchers and teachers [...] The research areas covered by these programmes reflect the themes that permeate the new discourses (poverty alleviation, gender and the environment), as well as the salient problems of the countries concerned [...] Moreover, many of the

\footnotetext{
422 Gaillard, J. (2003). "Tanzania: A Case of 'Dependent Science'." Science Technology Society 8(2): 317-343. pp328-329

423 Velho, L. (2004). "Research Capacity Building for Development: From Old to New

Assumptions." Science Technology Society 9(2): 171-207. p179

${ }^{424}$ Sandwich programs entail that for example MSc or PhD students spend parts of their training period at an HIC university and the other parts at their university in the LIC

425 Velho, L. (2004). "Research Capacity Building for Development: From Old to New

Assumptions." Science Technology Society 9(2): 171-207. pp179-182
} 
programmes (e.g. the natural science SIDA/SAREC programmes in Vietnam and Nicaragua [...]) have developed mechanisms to consult or to link up with the intended research beneficiaries outside academia. 426

Similar criticism as voiced in Velho's research was voiced in a 1994 Sida-commissioned evaluation conducted by Jaime Behar and Mats Lundahl:

Summing up, SAREC's support to research in Nicaragua has worked well in one sense, but not in another. It has financed a number of projects and programs which have produced output in terms of research results and high-caliber training. However, the support provided has not always been clearly in keeping with development objectives of the country and has been spread out among too many institutions and projects. The capacity-building aspects have been somewhat overlooked. These factors have, in turn, tended to lower the efficiency of the

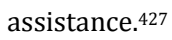

Another Sida-commissioned evaluation of the research cooperation with Nicaragua, written by Edgardo Moreno and Thomas Alveteg in 2003, refers to the quote by Behar and Lundahl above, and the authors state that though they agree with them to a large extent, the support to individual scientists was mainly dominant during the 1980's and early 1990's, and that this still had positive (albeit indirect and long-term) effects on Nicaragua's research capacity and subsequently its development and quality of life. ${ }^{428}$ Another argument presented in this evaluation (in the commentaries section) in defense of the individual training focus was that it is difficult to foster links between research and other actors in society when there is no critical mass of trained scientists:

All in all, the report includes an elaborate introduction about "development discourse", which ends up with denying itself. It namely concludes that innovations occur at the interface of research and economic activity. However, both are weak or not developed in Nicaragua and must be strengthened. There is, thus, no chance for a fruitful "interface" until the universities and research institutes are occupied with competent scientist who will be able to provide one side of the interface. How to develop the economic structure is not dealt with in the report, but if it will not be developed, there is little realism in proposing the "interface model" as an alternative to the currently operated model. ${ }^{429}$

\footnotetext{
426 Banzon Bautista, M. C. R., L. Velho, et al. (2001 ). Comparative study of the impacts of donorinitiated programmes on research capacity in the South The Hague, Ministry of Foreign Affairs/Directorate-General for Development Cooperation, the Netherlands p15 ${ }^{427}$ Behar, J. and M. Lundahl (1994). Now's the time. An evaluation of the Swedish development with Nicaragua, Secretariat for analysis of Swedish Development Assistance (SASDA). ${ }^{428}$ Moreno, E. and T. Alveteg (2003). Collaboration between Sweden and the Public Universities of Nicaragua Sida evaluations 03/31, Sarec. pp9-10 ${ }^{429} \mathrm{Dr}$. Jari Valkonen, SLU, one of the commentaries to 2003 evaluation, p198
} 
The 2003 evaluation seems to have been a contentious one, and though this example focuses on just one country, it illustrates the many tensions that can arise when discussing the why's and how's concerning research aid.

King's and McGrath's book Knowledge for Development (2004) includes a quite extensive analysis of the knowledge-related activities of Sida - including those of Sarec - in a comparison with British, Japanese and World Bank Aid. The study included both interviews and document studies and focused on exploring the knowledge discourse in aid. They conclude that despite talk of partnership, local ownership and capacity, aid still includes a troublesome amount of conditionalities. These conditionalities are in turn further encouraged by the increased demand for detailed accountability of public spending in high-income countries. ${ }^{430}$ They also maintain that the aid climate is such that speedy fund disbursements are desirable, something which does not necessary benefit indigenous capacity building efforts. ${ }^{431}$ They point out that despite evidence to the contrary, many donors within the area of "knowledge-based aid" seem to assume that knowledge, policy and development outcomes are automatically connected (linear reasoning). One assumption, for instance, is that stakeholders will act rationally according to the knowledge available. 432

In terms of the four aid actors they studied, King and McGrath conclude that in what they call technical cooperation and capacity development (which includes research) Sweden, through Sida - and not least Sarec - has made the clearest efforts to shift from a "deficit view" (focus on gaps) towards more "mutuality." 433 They also state, however, that Sarec's definition of knowledge (in the 2000's) seems quite "scientific and technical" when compared to the rest of Sida: "It is possible that this also leads to a greater sense of deficit and transfer than in other elements of Sida's discourse." 434 At the same time, they maintain that this is outweighed by the clear emphasis on demand-driven research agendas. According to them, the deficit view - closely coupled with a linear view of development - remained when Sarec was created in the 1970's, but gradually changed into a more systemic approach, much like the gradual change they claim took place at Sida in the view of how to promote development with increased knowledge. The first decades were characterized by the linear technology transfer view, and the 1990's and 2000's were characterized by a more systemic view of the role of knowledge, where local capacity played a more important part. 435

Swedish research cooperation with Laos was explored in a dissertation from 2007 by Ann-Louise Bäcktorp. She explored the intersection of education and gender in relation to development aid as expressed by aid actors (the World Bank and Sida) and

\footnotetext{
${ }^{430}$ King, K. and S. McGrath (2004). Knowledge for Development? Comparing British, Japanese, Swedish and World Bank Aid. New York, Zed Books Ltd. pp26-28 \& 44

431 Ibid. p29

432 Ibid. pp50-51

433 Ibid. pp45 \&134-135

434 Ibid. p136

435 Ibid. pp139-141
} 
local actors (the National University of Laos). ${ }^{436}$ The National University in Laos cooperated with Umeå University in Sweden on capacity building (research training for example). Bäcktorp asked, for example, whether the discussions about gender in cooperation agreements have any transformative effect. She concludes that Northern discourses on gender seem to be hegemonic. Similarly to Eriksson Baaz, she concludes that the concept of "partnership," 437 for example, is not easily realized in practice.

Gunilla Priebe's dissertation from 2009 (Gothenburg University) focuses on Swedish aid to Malaria research in Africa (MIM - the Multilateral Initiative on Malaria) but does not analyze the policy or role of Sarec in depth. Her study focuses more on how malaria research is constructed in a specific African context, addressing the broader problem of balancing donor and low-income country research inputs:

If the organisations that support research in and about Africa do not wish to reproduce colonial orders, it is essential for them to pay attention to the points made within Postcolonial Theory that fall within the Africanisation concept, i.e. to pay attention to the right to ownership and involvement in all stages of knowledge production, so that a continuing reproduction of discriminatory and unequal arrangements can be diminished or (ideally) put to an end. This means for research support not to imagine scientific work as an autonomous activity, and to not only focus on financial, infrastructural and institutional support, but to also evaluate the political and social effects of different forms of support. ${ }^{438}$

The MIM case illustrated that universal taken-for-granted views of what malaria is can be challenged in research cooperation. Knowledge other than academic and scientific knowledge is necessary in order to fully understand malaria. ${ }^{439}$

\section{Concluding reflections and the contribution of this study}

To summarize the "verdict" on Sarec judging from previous research - in all its diversity - one could say that while it has sometimes been considered as bordering neocolonial science, altogether it has been engaged in comparatively praiseworthy activities during its existence. The methods and scopes of the studies vary greatly, covering a wide spectrum of disciplinary areas and topics. A systemic approach (which is often represented by the use of systems of innovation and mode 2 for example) is upheld by previous research as preferable to a linear approach (where support is focused on smaller parts of the system, like research training or individual projects). The risk of maintaining or increasing dependency is an ever-present dilemma, and research aid seems to contain unavoidable tensions, such as the one of resource inequality between partners. Another tension consists of the sometimes conflicting time-frames of development research

\footnotetext{
${ }^{436}$ Bäckstorp, A.-L. (2007). When the first world goes local. Education and gender in postrevolution Laos, Umeå University. pp18\&22

437 Baaz Eriksson, M. (2005). The Paternalism of Partnership, Zed Books.

438 Priebe, G. (2010). Att afrikanisera vetenskaplig kunskap. MIM och malariaforskningen i ett postkolonialt dilemma, Göteborgs universitet. pp300-301

439 Ibid. pp299-300
} 
versus research capacity building. The fact that research aid straddles the boundary between research and aid policy is clearly a challenge, considering that these areas in and of themselves are challenging enough.

Some of the researchers I have discussed in this chapter have presented topics and areas that they believe should be further explored. Bradley claimed that the "donor side" has received a large portion of the attention - which could potentially be an argument against my choice of focus. Nevertheless, a study of Swedish research aid in this perspective has not been done. Shedding light on the ideas and imaginaries that characterize the policy direction of a pioneer aid actor is something that can be interesting within several field of research as well as for development practitioners and policymakers. The discourses and imaginaries of Sarec do not just reflect Swedish aid, it can provide interesting contrast to other countries' aid policies as well. 



\section{1973-1979: Tracing foundations}

The connexion between research [...] and development is just as obvious as the thesis that increased knowledge is necessary to enable man to deal with and master the situation confronting him. . $^{40}$

International and regional [aid] projects are sometimes used to preserve colonial influence, to establish neo-colonial dependence and to circumvent national priorities. $^{441}$

- Sarec's first annual report 1975-1976

Sarec's first years seem to have been quite eventful and exciting. There were paradigmatic clashes between academic and political schools of thought. Social democrat Olof Palme was prime minister. There was a leftist political wave for much of the 1970's after the 1968 movements, but towards the end of the decade, neoliberal values became more dominant. ${ }^{442}$ As discussed in chapter 1 , aid politics were characterized by the effects of for example high oil prices, reduced economic growth in high-income countries and budding financial crises. There was growing critique of the strong focus on economic growth in aid policies; poverty reduction and distribution of resources came higher up on the agenda. ${ }^{443}$ Swedish aid was provided to independence movements in for example Guinea Bissau, Mozambique and Angola, and support was also provided to anti-apartheid movements in South Africa and Namibia. Swedish aid policy, along with that of Canada, the Netherlands, and Norway was underpinned by a "humane internationalism", according to development policy researcher Olav Stokke. This entailed solidarity-based goals focused on poverty reduction grounded in a conviction that the social and economic development of low-income countries also benefited the so-called Western or industrialized countries. ${ }^{444}$

Research politics in the 1970's were, according to Melander, affected by many of the same world events as aid politics, such as current debates on for example the war in Vietnam and the nuclear threat associated with the Cold War. The potentially destructive role of research was a hot topic and demands were made to politicize and

\footnotetext{
${ }^{440}$ Sarec (1977). Sarec's First Year, Annual Report 1975/1976. p8

${ }^{441}$ Ibid. p32

${ }^{442}$ See for example Nederveen-Pieterse, J. (2010). Development Theory (2nd ed), Sage

Publications. p7

${ }^{443}$ Odén, B. (2006). Biståndets idéhistoria: från Marshallhjälp till millenniemål. Lund,

Studentlitteratur. pp74-76

${ }^{444}$ In line with the ambition of the New International Economic Order (NIEO) was presented in 1974 at a UN conference as an alternative to the Bretton Woods international economic system (which was considered by low-income countries as mostly beneficial to its founders), Stokke, 0 . (1989). Western Middle Powers and Global Poverty. The Determinants of the Aid Policies of Canada, Denmark, the Netherlands, Norway and Sweden, the Scandinavian Institute of African Studies. pp10-11
} 
democratize science. Research politics of the 1950's and 1960's conceived of science as progress, whereas the 1970's came to be more about problem-solving. ${ }^{445}$ There were fundamental differences of opinion regarding the production and use of knowledge, including the value of scientific knowledge and rationality. The OECD produced a number of significant reports during the early 1970's that defined what was to be regarded as relevant research for society. ${ }^{446}$ Problem solving was the goal, and the concept of "sector science" was used to symbolize an alliance between science and politics. ${ }^{447}$ Benner calls this a combination of knowledge pessimism ${ }^{448}$ and steering optimism; something very clearly embraced by Sweden. ${ }^{449}$ Some of the "waves" described above can be seen in the material - sometimes very clearly - and sometimes more subtly.

The main purpose of this chapter is to trace part of Sarec's foundations and provide an analysis of the policy development of the first years. The chapter is partly chronological and partly thematic and discusses how Sarec's policies developed and changed during this period as portrayed by annual reports and other central documents. More specifically, I illustrate how Sarec framed their task discursively, how the relationship between science and technology, aid and development was portrayed and how programme areas and methods of work ${ }^{450}$ were seen to contribute to the goals.

Two main discourses are identified - the universalist and the localist. These discourses will be discussed in more detail at the end of the chapter, but to facilitate the reading of the chapter it is necessary to saw a few words at the beginning as well. The universalist and the localist discourses can be seen as two central perspectives that flow through the policy development of Sarec during its entire existence. They represent different views of science, knowledge and development. Having said that, they share some common ground. Both discourses believe in the power of Western science to enable development in low-income countries, and they consider local/national research capacity to be central. They differ in views of how to achieve development through the use of research; defining development problems in different ways and underlining certain modes of support over others for example. The localist discourse, with its stronger

\footnotetext{
445 Melander, F. (2006). Lokal forskningspolitik. Institutionell dynamik och organisatorisk omvandling vid Lunds universitet 1980-2005, Lund University. pp119-120

${ }_{446}$ According to political scientist Magnus Eklund, the OECD has had and continues to have very strong legitimacy in science policy issues. Eklund, M. (2007). Adoption of the Innovation System Concept in Sweden, Uppsala University. pp12-14

${ }^{447}$ Benner, M. (2008). Kunskapsnation i kris. Politik, pengar och makt i svensk forskning, Nya Doxa. pp26-28

${ }^{448}$ Benner exemplifies this budding and rapidly increasing critique of science with reference to early STS publications like Mulkay, M. (1979). Science and the Sociology of Knowledge, Allen \& Unwin. and Woolgar, S. and B. Latour (1979). Laboratory Life: The Social Construction of Scientific Facts, Sage Publications.

${ }^{449}$ Benner, M. (2008). Kunskapsnation i kris. Politik, pengar och makt i svensk forskning, Nya Doxa. pp26-27

450 Programme areas refer to the areas that Sarec divided its activities into, such as bilateral research cooperation, support to international research organizations and support to Swedish development research. I call the programme areas modes of support. The different modes of support are associated with specific types of activities, such as research training, projectsupport, or support to infrastructure.
} 
emphasis on context and reflexivity, is dominant during the first and founding years. The universalist discourse is always by its side, however, underlining the general validity of international research results and defining development in more linear terms. The concepts of boundary organization and sociotechnical imaginaries are also used in this chapter to discuss what characterized Sarec's existence during its first years.

\section{Swedish research-related aid before Sarec: setting the scene}

Research-related support in different forms had been a part of Swedish aid since 1952. This first type of research aid consisted mainly of large grants for stipends and to some extent also applied development research through support to various UN organizations for instance. ${ }^{451}$ Government bill 1962:100 - also known as the "foreign aid bible" 452 among other things stated that there were no "principal obstacles" to including support for research in aid projects as long as it was tied to practical application in areas such as family planning and nutrition. International organizations - such as different UN bodies were considered more adequately equipped to conduct development research of the more basic kind. ${ }^{453}$ In other words, the focus of research aid in the beginning was mainly on development research where the research itself tended to be conducted in high-income country settings and the results were to be applied in the low-income countries.

In 1965, an expert group involved in research policy advice was given the task to suggest guidelines for the newly formed Sida concerning support to research. The group's suggestions were in line with those in the 1962 bill - applied research aimed at central "problem areas" could be included, and preferably within bilateral projects. ${ }^{454}$ In addition to family planning and nutrition - farming, microbiology, biotechnology and population research were seen as reasonable areas to include, given that they were considered relevant and applicable in low-income countries. The group also suggested that Sida should establish a special cooperation committee with the Swedish research councils. ${ }^{455}$ The parliament discussed the role of research in development more frequently towards the end of the 1960's and demands for a proper investigation into the issue were made several times. ${ }^{456}$ In 1970 , Sida requested the possibility to support local research institutions in their bilateral aid projects and their research aid efforts then expanded in quantity and kind. 457 The focus remained mainly on applied development research but a new kind of discussion was under way.

${ }^{451}$ SOU1973:41 (1973). Forskning för utveckling. Betänkande av u-landsforskningsutredningen. Statens offentliga utredningar. Stockholm., pp9-10, and ch4\&6

${ }^{452}$ See for example Odén, B. (2006). Biståndets idéhistoria: från Marshallhjälp till millenniemål. Lund, Studentlitteratur. p65

453 SOU1973:41 (1973). Forskning för utveckling. Betänkande av u-landsforskningsutredningen.

Statens offentliga utredningar. Stockholm. p112

${ }^{454}$ Ibid. p112-113

455 Ibid. p113

456 Ibid. pp113-114

457 Ibid. pp114-115 


\section{Research for Development - the 1973 investigation report}

A committee was appointed in 1971 by Cabinet Minister Sven Moberg (social democrat) with the purpose to investigate issues surrounding the organization and direction of research-related to problems in low-income countries. They were asked to suggest which research areas Sweden should focus on, what mix of activities to pursue, as well as how an organization could be put together. 458

The report summarizes trends in development theory and reviews Sweden's previous development research-related activities as well as of other high-income country agencies such as those of Great Britain, the Netherlands and Canada. According to the authors, in the late 1960's and early 1970's, development-related research was beginning to yield useful results within both the social and natural sciences and the importance of research for development became more widely recognized. 459

The committee consisted of university researchers and representatives from Sida and the Ministry of Education: Nils-Gustav Rosén (previous chancellor of Swedish universities), Sune Bergström (The Karolinska Institute), Gunnar Hambraeus (The Swedish Academy of Engineering Sciences), Lennart Hjelm (The College of Agriculture), Ernst Michanek (director-general of Sida), Karl Eric Knutsson (Stockholm University), and Manfred Ribbing (The Ministry of Education). ${ }^{460}$ They presented their investigation report in 1973 - Research for Development (SOU 1973:41). 461 Given that the report by the committee on development research was the base on which Sarec was created, I will delve a little deeper into some parts of it as well as some of the aftermath of its circulation. ${ }^{462}$

\section{Redefining central concepts}

Detailed discussions about concepts like development, underdevelopment, research and development research introduce the main body of the report. The authors are critical of the different concepts that are used to describe the countries in question - for example the concept developing country (u-land):

One may for example choose countries South of a certain latitude, countries with a national income lower than the world average or countries with a literacy level under a certain percentage. [...] Among Southern countries are South Africa and Australia. If we depart from national per capita income, Venezuela ranks higher than

\footnotetext{
458 Ibid. p12

459 The reports written after the first UN conference on science and technology in 1963 (United Nations Conference on the Application of Science and Technology for the Benefit of the Less Developed Areas (UNCSAT) in Geneva) are referred to as important reasons for this increased recognition.

460 Several other people were also involved. See the report.

${ }^{461}$ SOU1973:41 (1973). Forskning för utveckling. Betänkande av u-landsforskningsutredningen. Statens offentliga utredningar. Stockholm.

462 The investigation report is in Swedish so the quotes are my translation.
} 
Italy and Ireland. When it comes to literacy, countries like Argentina and Chile are on a Southern European level. ${ }^{463}$

It can be seen as an attempt to highlight the diversity that is hidden when using such a homogenizing terms. The discussion on the difficulty of finding adequate definitions continues in the report. Development, they maintain, is an "irreparably ethnocentric" Western concept "building on the perception of development as organic growth which is continuous, occurs by an inner logic, has a certain direction and implies increased differentiation and complexity". ${ }^{464}$ Low-income countries are expected to follow the same stages as high-income countries have gone through, and if they do not - it is because something is missing. There is a large degree of generalization in this way of thinking, not mirroring the diversity within and between countries very much.

The authors position themselves against these traditional, more strictly economic views of development like modernization theory with reference to Walt Rostow and the stages of economic growth. ${ }^{465}$ Stage theories, they maintain, have been used to justify the imperialism of the West. They attempt to redefine development by adhering to dependency theory instead, including perspectives on power and context using the work of for example Samir Amin and Gunnar Myrdal. The committee advocates a structural view of development and underdevelopment, where the inequalities in the world are seen as a result of international system of dependencies which has centres and peripheries. ${ }^{466}$ Underdevelopment - the result of a country's disadvantaged place in a larger system of dependencies - is historically contingent and makes development very difficult, claims the committee. ${ }^{467}$ Underdevelopment can be described economically, socially and politically as having the preconditions but not the ability to use appropriate technology, have access to education, health and security as well as power to affect one's own life. ${ }^{468}$

"The growing capacity of individuals, groups and nations to control their own situation and to make improvements of it" (based on their own values), therefore, is central to development according to the report. 469 This line of reasoning makes underdevelopment the opposite of capacity. Capacity was a key concept throughout Sarec's history even though it was not mainstream in development language until the 1990 's. ${ }^{470}$ The concept of third world is advocated (with reference to Louis Irving Horowitz

463 SOU1973:41 (1973). Forskning för utveckling. Betänkande av u-landsforskningsutredningen. Statens offentliga utredningar. Stockholm. p24

464 Ibid. pp23-24

465 Economic development according to Rostow's theory (1959) could be divided into five stages: the traditional society, preparations for "take off", "take off", the mature society, and the society of mass consumption.

466 SOU1973:41 (1973). Forskning för utveckling. Betänkande av u-landsforskningsutredningen. Statens offentliga utredningar. Stockholm. pp22-25

467 Ibid. p25

468 Ibid. p25

469 Ibid.

470 See for example Lusthaus, C., M.-H. Adrien, et al. (1999). Capacity Development: Definitions, Issues and Implications for Planning, Monitoring and Evaluation. Universalia Occasional Paper. 
book Three Worlds of Development from 1966) because it opens the possibility of a third road, independent of set stages. ${ }^{471}$

The report delves deeper into the question of what research is - and what it is not. Research is divided into primary and secondary activities, where the former includes knowledge production, method development and theoretical contribution. Secondary activities refer to things such as capacity building through for example PhD education, infrastructure establishment, institution building and efforts to spread research results. ${ }^{472} \mathrm{~A}$ parallel is drawn to $\mathrm{R} \& \mathrm{D}$, but the committee claims that this classification builds on a static view of the research process which isolates basic research from applied research: "Our opinion is that the relationship between these types of research is best described from a view of research as a unified, continuous process." 473

The committee takes a stand against what they in different places call a static, linear, modernistic and economistic view of science and technology and instead supports a relational, systemic perspective (or structural as they call it). ${ }^{474}$ They make a distinction between different kinds of development research - for example that which is thought to contribute to economic growth and that which is thought to contribute to other values, more difficult to quantify:

\begin{abstract}
Within development research it is of essence that the researcher as much as possible relates their work to expected results. This does not necessarily mean a demand for strictly economic estimates. Other results which provide convincing arguments for financing of research is the development of intellectual, innovative capacity, increase in methodological competence, talent and of course an increase of the total body of knowledge. 475
\end{abstract}

The different stands taken concerning definitions and views of example development and research seems largely built on a development theory literature review by economic historian Björn Hettne (a study which is also attached as an appendix in the committee report). Hettne maintains in his review that the debate on views of development up until then could be said to represent two approaches - the studies which were based on a static descriptive perspective and those based on a historic structural perspective (herein forth shortened to descriptive versus structural). ${ }^{476}$ The descriptive perspective tended to result in studies which described underdevelopment through focusing on gaps or things lacking; economic, technological, demographic, social or psychological aspects or dimensions (lack of education or lack of capital for example). Common solutions to these

35. and Whyte, A. (2004). Landscape Analysis of Donor Trends in International Development. Human and Institutional Capacity Building. t. R. Foundation.

471 SOU1973:41 (1973). Forskning för utveckling. Betänkande av u-landsforskningsutredningen.

Statens offentliga utredningar. Stockholm. p17

472 Ibid. p27

473 Ibid.

${ }^{474}$ Ibid. p29

475 Ibid.

476 Ibid. pp163-164 
problems were increased international trade or more foreign investment, to help the countries "catch up". 477

The structural perspective, on the other hand, tended to study the reasons behind underdevelopment and the mechanisms sustaining these states. Many factors were considered relevant, and of different significance depending on the historical situation in focus. ${ }^{478}$ Hettne uses a sports metaphor (from a 1972 conference, Science and the World Tomorrow) to describe the structural perspective:

\begin{abstract}
We imagine a number of commercially driven soccer teams playing in the same league. Some of them are more successful than others. They attract bigger audiences to their games and therefor get greater income. As a result, they can offer their players better training possibilities, become even more successful and make more money. They can start buying the less successful teams' best players, whereby these teams become worse and have a harder time improving their position in the league. ${ }^{479}$
\end{abstract}

Once an imbalance has been established, it is difficult to break patterns and resource flows. Representatives of this view according to Hettne were Andre Gunder Frank, John Desmond Bernal and Marxist perspectives such as the dependency school and other centre-periphery models. Assumptions they shared in common were that underdevelopment is to a large degree the result of imperialism and colonialism, which have been characterized by political oppression and economic exploitation. 480

The committee applies this perspective to research, maintaining that the little research taking place in the poor countries at the time was largely of the same kind as in rich countries, conserving dependencies rather than being a result of independent problem identification. ${ }^{481}$ This does not mean, they say, that research activities from different traditions have not taken place but rather that different historical settings have valued knowledge in different ways and the specific "Western" science tradition (as the authors call it) has become dominant. It has, furthermore, focused not least on natural sciences and technology and increasingly been used to serve economic interests. ${ }^{482}$ As a complement, they advocate increased multi- and/or cross-disciplinary research based on an understanding of development problems as complex and in need of attention from various academic disciplines and not primarily with the goal of contributing to economic growth. The committee argues that capacity - being central to development in their definition - should be one of the main goals of the research activities to be supported. 483

The case the committee makes, in other words, is that high income countries have a tradition where natural and technological sciences have been the model for other

\footnotetext{
477 Ibid. pp19-21

478 Ibid. pp19-21

${ }^{479}$ Ibid. p25

480 Ibid. p160

${ }^{481}$ Ibid. p23

482 Ibid. p26

483 Ibid. p15
} 
sciences. These model sciences have also associated with increases in economic productivity for example. The committee maintains that this model should not to be taken for granted, and research in low-income countries has to spring from priorities in their own context. On a scale from localist to universalist, the committee's discourse could be labelled localist given that it is critical of certain taken-for-granted assumptions about both science and about high versus low-income countries for example. A greater number of futures are theoretically made possible with a localist sociotechnical imaginary. Research aid policy, however, is of course placed within a larger aid discourse, which makes possible certain discussions and not others. In other words, what I call localist is relative to what are established as more traditionally accepted assumptions. For example, at the time it was still fairly common to view the role of science and technology in development as consisting of directly transferring the results of high-income country development-relevant research to low-income countries based on the assumption that "Western" knowledge was universal (technology transfer). This view would, according to my reasoning above, belong to the universalist discourse.

So what kind of research was to be supported? As mentioned earlier, the committee suggests that cross-disciplinarity is particularly relevant for development research because they claim that solutions to development problems require many different scientific perspectives as well as a problem-based approach. ${ }^{484}$ Furthermore, they underscore that the research should be value-relevant; based on the priorities of the low-income country. A certain level of normativity was therefore demanded; the "weaker" part was to be strengthened, and academic colonialism was to be avoided. ${ }^{485}$. In the same context, an interesting division between different sciences is made in regard to how much they were considered to be affected by the researcher's values.

No researcher can in their work rid themselves of their values, that is - ideas about desirable and undesirable within their area where he does research. Within certain sciences, this relation is so straight forward that it does not create problems, since the values are generally accepted. ${ }^{486}$

The formulation above illustrates that some sciences were regarded as more straightforward and universal (the values are considered generally accepted). Medical science was at the time considered the least problematic since it "in its whole is based on the fundamental value of improving health status." 487 This assumes that all countries agree on what "good health status" is or that there are no commercial interests embedded in medical research for example.

The same reasoning is used when discussing natural sciences and technology, where value-related issues are not seen to be of consequence until after the researcher has done their job - in the application phase. The committee holds that the

\footnotetext{
484 See for example ibid. pp16, 18, 20, 29 \& 30

485 Ibid. pp29-32

486 Ibid. p31

487 Ibid. p31
} 
issue of values, however, is constantly present in social science research given the types of questions it deals with. ${ }^{488}$ This issue is raised in other parts of the report as well (in the context of discussing Swedish researchers and their capacity to engage in development relevant research):

It is necessary to distinguish between research which is general in character and generalizable and research which is completely dependent on locally given circumstances. To the former belong the majority of the natural sciences, not least the basic kind. To the latter belong the majority of the social sciences and cultural research, botany, ecology, geology, hydrology etc. ${ }^{489}$

Here it is even more clearly established that there is a difference in how the sciences are perceived. With regards to the values of researchers then, while the Committee acknowledges the "situatedness" of researchers, they seem to consider it kind of a problem and underscore that increased cross-disciplinarity and development relevance should not occur at the expense of scientific quality. ${ }^{490}$ This illustrates that there is a tension between what is considered scientific quality vis-à-vis development relevance. Development relevance is essentially considered less important than scientific quality. It expresses an ambition to acknowledge the importance of context and local conditions - even when it comes to science - but taking a step back soon thereafter.

The committee agreed that regardless of discipline and tradition, all research has in common that it seeks to "increase knowledge about - and deepen understanding of - different phenomena, as well as such principles and relationships which increase the ability to solve problems and control events". ${ }^{491}$ In this sense, research is seen as vital for development regardless of whether the goal is economic growth or standard of living, for example. Which specific areas or problems to research, however, need to be independently identified in order to be relevant for the low-income country in question, and not modelled on high-income country research priorities. ${ }^{492}$ At the same time, the Committee claims that it is important to engage in both basic and applied research based on the assumption that scientific innovation is dependent on both kinds. ${ }^{493}$ Several kinds of research are presented as relevant for development; mapping and statistical investigations (in line with the descriptive view), thematic research (areas like tropical medicine or agricultural research), and development theory research (in line with the structural view). ${ }^{494}$

A number of tensions arise. The Committee simultaneously sustained and tried to deconstruct what "research for development" was and should be. It is evident that adopting a localist view of development was not straightforward. The low-income

\footnotetext{
488 Ibid. p31

489 Ibid. p125

${ }^{490}$ Ibid. pp30-31

491 Ibid. pp25-26

${ }_{492}$ Ibid. pp19-21

${ }^{493}$ Ibid. p34

${ }^{494}$ Ibid. pp27-29
} 
countries should independently identify priorities for research instead of imitating highincome countries - but at the same time they should do this in a certain way. Even though countries are said to have different preconditions and historical context, the picture of how research works is clear (universally valid?), and it is also clear what is missing in order for development research to be able to be conducted (traces of stage theory?). What the Committee was saying, essentially, was that the low-income countries first needed to imitate the high-income country research systems to then be able to independently prioritize which kind of development research to engage in. This could perhaps be described as a kind of system transfer, as opposed to technology transfer.

Two different and partly competing perspectives are articulated in this founding document; the universalist discourse and the localist discourse. Both of them value modern science as a solution to development problem, and consider national research capacity as important. The discourses and the central objects that define them will be discussed in more detail at the end of the chapter, and can more or less explicitly be followed throughout Sarec's entire existence.

\section{The organization-to-be}

The Committee suggested that the most important conditions that should steer the initiative's direction were (in order of priority) the premises of development theory, foreign aid goals, the available research capacity in Sweden and lastly the demands for international coordination. Research activities should to be tied to the specific foreign aid goals of each context, and the organization-to-be was to be based on a number of principles such as value-relevance problem-orientation and multi- or crossdisciplinarity. 495

The direction should have as its point of departure a well thought through view of the problem, nature and causes of underdevelopment so that the research, regardless of the area in which it is conducted, can contribute to breaking the conditions of underdevelopment and in the long term counteract the forces that create or maintain underdevelopment. ${ }^{496}$

With regard to foreign aid goals (or development goals as they sometimes call them), the report states that in order to make them concrete in each specific context, prior efforts need to be assessed with regard to their success and the national preconditions (political, economic, sociocultural, etc.) should be taken into consideration.497 Situations characterized by underdevelopment, they maintain, have certain basic features in common which constitute obstacles to "the general goal of development work", things like the inability to:

- build new political structures;

\footnotetext{
495 Ibid. pp133-134

496 Ibid. p123

497 Ibid. p124
} 
- distribute wealth adequately to reduce poverty;

- offer meaningful occupation to a large part of the population;

- attain good balance in the international exchange between developing and developed countries;

- mobilize enough people in development efforts;

- to start effective population politics both in terms of human reproduction and of reducing the concentration of people in large cities;

- to avert human rights violations from those in power. ${ }^{498}$

The Committee puts forth that these situations are so partly because of lack of political will but also because the causes of underdevelopment need to be better understood. I will return to this but one could reasonably claim that the identification of inabilities above is associated with the universalist discourse and is akin to the identification of gaps in stage theory.

The committee recommended that both long-term and short-term research efforts should be supported in order to avoid tendencies to engage only in applied research for example. Active efforts were to be made to support social science research since it tended to be under-prioritized. ${ }^{499}$ A precondition to being able to support development research at all, they maintain, is research infrastructure. In defining what kind of research infrastructure is relevant, they align themselves with the classifications that UNESCO had developed together with the Canadian IDRC and the University of Sussex. 500 It consisted of four "levels of function":

1. Planning, decisions and follow-up. These functions tended to be closely aligned with government.

2. Coordination, support and financial issues on a national level. These functions tended to be very split up depending on the types or levels of research (different subject areas, and whether it was basic or applied research)

3. All institutions which conduct the research: institutions for teaching and research, technical institutes, research and experiment institutions (sector-driven, applied research)

4. The scientific and technical service functions of UNESCO. Not directly responsible for teaching or research but essential for enabling science and technology for development (such as topographical institutes, databases, museums, and innovation actors) ${ }^{501}$

The Committee aligns itself with the above, but they also add that all support to research capacity needs to be based on an analysis of countries' preconditions in relation to research infrastructure, administration and personnel. ${ }^{502}$ It is common, they claim, that the few researchers that exist are too aligned with problem identification according to Western academic traditions and not in tune with the social and cultural context of the

\footnotetext{
${ }^{498}$ Ibid. paraphrased from 124

${ }^{499}$ Ibid. p34

500 Ibid. p44

501 Ibid. paraphrased from pp44-45

502 Ibid. p46
} 
low-income country. Increasing the amount of researchers, they claim, is something which is made difficult by the state of current research environments and brain drain to more "advanced" countries or to highly qualified positions within the country in question.

...problems which can be summarized as "external" and "internal" brain drain. Furthermore, there is a social and psychological climate which provides insufficient intellectual stimulus and which in many cases is directly innovation-hostile. ${ }^{503}$

What they mean, more exactly, with "social and psychological climate" or "innovationhostile" is not clear, but it is interesting to note the associations being made between wellfunctioning research environments and innovation. Judging from the report, innovation in this context seems to refer to the ability of low-income country researchers to contribute to the independent solution of problems by being able to conduct research on their own as well as interpret and adapt results from other research (regardless of which kind of development it is for). ${ }^{504}$ Referring again to the work of the UN Advisory Committee on Application of Science and Technology (ACAST), the Committee mentions institutional networks as a way of conceptualizing how each "research unit" is part of a "larger integrated system, where the different components are coordinated with the purpose of guaranteeing an effective use of the research resources". ${ }^{505} \mathrm{~A}$ systemic view of science and technology is underlined.

Swedish research capacity concerning development issues also required improvement, according to the Committee, Swedish researchers needed to become more familiar with development issues. International coordination of research cooperation that is, staying informed on the work done by the UN for example - and working towards creating links with Swedish research and with research in (and between) the developing countries - was also seen as an important task for the organization to be. ${ }^{506}$ In general, they often underscore the importance of making sure that the research be conducted in the developing country context as much as possible, at the same time as they claim that some efforts may need to start or be built up in the industrialized country due to costs or other resource availability. ${ }^{507}$

Organizationally, the Committee proposed that it be an independent development research board (nämnd för utvecklingsforskning). One option was to suggest that it be a research institute, but the task was considered too wide for this. Dividing the task between the existing research councils was another option, but this was rejected on the grounds that this would not satisfy the need for cross-disciplinarity. Adding a new research council would not cover the other tasks required by the organization-to-be. ${ }^{508}$ Instead, an independent board was recommended, to operate under the Ministry of

\footnotetext{
503 Ibid. p46

${ }^{504}$ See for example ibid. pp46-47

505 Ibid. p47

506 Ibid. pp124-126

${ }^{507}$ See for example ibid. p131

508 Ibid. pp134-135
} 
Foreign Affairs, funded by the foreign aid budget (to be $5 \%$ of the total annual budget). It was to have a board of directors, a secretariat, a secretary general and an administrative director. Its board of directors was to be composed of both researchers and representatives from the foreign aid administration and public interests. Their task would be to act proactively, judge applications (a research council function), and provide advice. They were to have an international advisory group tied to them, to be composed of different representatives depending of the nature of the advice sought and they could create temporary Swedish consultative researcher groups as well.509

The Committee stated that the development research board was to be a complement to Sida as well as to the existing research councils. While Sida supported research more as a practically oriented part of other on-going aid, the organization-to-be would focus on supporting research more long-term. This did not imply that the two should not overlap in tasks; this was in fact encouraged when deemed necessary. ${ }^{510}$ The same principle was to be adhered to in relation to the research councils, the tasks overlapped to some degree and cooperation was desirable.

\section{Economists protest. A battle to define the problem and its solution.}

Several of the recommendations by the Committee could be interpreted as a critique of both foreign aid and research at the time since they proposed a number of new definitions and approaches. As I mentioned earlier, the report nonetheless received mostly positive response from the agencies and organizations to which it was sent for consideration. ${ }^{511}$ The report, however, did lead to some clashes of opinion in the Swedish journal Economic Debate. The definitions of development and the appendix about development theory were the main issues discussed.

The Committee report's definition portrays levels of development as relative and dependent on past and present structural options and restrictions. It does not in itself seem to prescribe what kind of development is desirable, and it does not lift any specific aspect (such as income, education or access to healthcare) as central indicator of development as more central than others. Economists Bo Södersten and Mats Lundahl (at the time based at the universities of Lund and Gothenburg respectively) criticized the report and the Committee members, claiming that the economic discipline dominated development research because economics is central to development. They stated that the report did not adequately acknowledge this, and said that too much time was spent on for example defining concepts like underdevelopment in terms that seemed to them like "straining mosquitoes and swallowing camels." 512 Furthermore, they wrote:

\footnotetext{
${ }^{509}$ Ibid. pp135-138

510 Ibid. p140

511 (1975). Regeringens proposition med förslag till statsbudget för budgetåret 1975/76 pp29-

32

512 Södersten, B. and M. Lundahl (1974). Forskning för utveckling. Ekonomisk debatt, Nationalekonomiska Föreningen. 2. p115
} 
..to say that a fundamental aspect of the development concept is to be in charge of one's own situation and being able to improve it is the same as saying that development is about the ability develop. A more futile definition of development is hard to imagine. ${ }^{513}$

Instead, they maintained, it should have focused on the most important challenges for development research to solve (such as low production capacity and income inequality for example). In other words, Lundahl and Södersten suggested that the Committee did not approach their task appropriately. Furthermore, they claimed that the development theory review in the report (by Björn Hettne) was faulty and did not present an up-todate picture of development research, especially not of development economics. They argued that Hettne presented out-of-date "grand theories" rather than the kind of theory and application which was relevant at the time,514 and that he did not have enough evidence to state that development research was becoming more cross-disciplinary. They did not think that it was necessarily a good idea with more cross-disciplinarity either, arguing that specialization more often allows for the required depth. ${ }^{515}$

The reply from Hettne and Karl Eric Knutsson labelled the critique as being lacking in nuance and too narrowly focused on economics. They rejected Södersten's and Lundahl's claim that economic research was not given attention in the review of development theory since a third of the references in the review were to economists. ${ }^{516}$ They also maintained that the critique concerning cross-disciplinarity was "odd", and they presented some examples of economists who explicitly pointed out the need for broader perspectives and approaches to development problems (Gunnar Myrdal, Samir Amin and Hans Singer). ${ }^{517}$ Södersten and Lundahl countered by calling the examples "peripheral"; though they also concurred that cross-disciplinary efforts could sometimes be appropriate. ${ }^{518}$

On the topic of the proposed organization, Södersten and Lundahl agreed that that independence was a good idea, stating that critical and creative research needed a non-bureaucratic atmosphere: "Bureaucracy in research contexts almost always turn out to be a purpose of its own: good coins are out crowded by bad, seeds are replaced by shells." 519 They clearly did not hold Sida in such high regard, but they believed Sida and the board would be able to have fruitful cooperation (as well as conflicts). They also underscored the importance of including scientifically competent people to the secretariat. ${ }^{520}$ They ended their article by saying that the lack of economic perspectives in the report was bizarre. In response to this critique, Knutsson and Hettne maintained that

\footnotetext{
513 Ibid. p120

514 Ibid. pp436-437

515 Ibid. pp116-119

516 Hettne, B. and K. E. Knutsson ibid.Tvärvetenskap eller ämnesimperialism i u-

landsforskningen? 6. pp373-374

517 Ibid. pp374-375

${ }^{518}$ Södersten, B. and M. Lundahl ibid.Forskning för utveckling. 2. p119

519 Ibid. p121

520 Ibid. pp121-122
} 
the protests by Södersten and Lundahl were contradictory, sweeping and relatively trivial. ${ }^{521}$

The exchange above ended with a short reply from Lundahl and Södersten Knutsson, in which they maintained that Hettne and Knutsson clearly did not understand the critique. The diversity within economic research on development was much wider than the Committee report showed, they wrote, asking for continued investigation into the issue..$^{522}$

Another article on the subject appeared the year after, by economist Arne Bigsten (then at Gothenburg University). It further questioned the definition of development that the Committee report put forth. Bigsten maintained that it was not necessary for a definition of development to include an explanation of the causes of development. He questioned the decision to include power (ability to control one's own situation) as a variable, claiming that the definitions of development provided by economics were more useful (distinguishing between growth, economic development and development for example). ${ }^{523}$ No reply was provided by Hettne or Knutsson, but all the articles were filled with harshly phrased remarks - illustrative of a major clash in views about what was considered central to development at the time.

Karl-Eric Knutsson unfortunately passed away in 2002, so his perspectives cannot be analyzed here in the same manner as subsequent directors. I have, however, interviewed Björn Hettne given that he wrote the appendix on development theory in the Committee Report. During our interview, I asked Hettne about the discussion on development theory in Economic Debate, and part of his reflection was that it was a paradigmatic war during a time when tough exchanges were more common:

It was very much the spirit of the time - very polemic after 1968 - some sort of radicalism in the air. The fact that I discussed Marxism and the bourgeoisie in the beginning isn't something one would do today - and not before then either - but at the time it was legitimate [...] The debate was harsh and polemic. ${ }^{524}$

Hettne goes on to say that it was not uncommon for people from different disciplines and perspectives to get quite furious during joint seminars, but he claims that the international research trends at the time provided support for the findings put forth in the Committee report. ${ }^{525}$ Another point of controversy was the political decision of the proposed independence of the organization-to-be. Hettne stated that the Committee was very eager to avoid Sarec becoming a mere extension of Sida:

\footnotetext{
521 Hettne, B. and K. E. Knutsson ibid.Tvärvetenskap eller ämnesimperialism i ulandsforskningen? 6. p376

522 Lundahl, M. and B. Södersten ibid.U-landsforskningen. Replik till Hettne och Knutsson. 7.

${ }^{523}$ Bigsten, A. (1975). Om u-landsforskningsutredningens forskningsbegreppibid. 2.pp135-136

524 Transcription (2013). Interview with Björn Hettne 020513. p2

525 Ibid.
} 
We pursued very strongly that it was to be an independent organization with intellectuals who themselves were to prioritize what was worth prioritizing... and that it should not be subordinate to regular aid. 526

This is a clash between different discourses on both development and knowledge. The issue of cross-disciplinarity could be seen as one that captures major aspects of this clash. The economists adhere to the idea that disciplinary research, in this case economics, is most apt to deal with development. Development is to large degree about economic growth, even though contexts can vary somewhat. The anthropologist and the economic historian, on the other hand, believe that contexts vary much more and that development is a multi-dimensional problem which is best approached through the cooperation of several disciplines. Both, however, believe in modern science as a solution to development problems. The exchange in economic debate and the interview with Hettne illustrate some of the intense boundary work that was going on at the time. How much influence should politics have over science, and who within science could decide which kind of research was relevant to support as a state agency?

\section{Sarec takes form}

The question of the organizations' independence divided some of the organizations to which the report was sent for comments. Some believed the independence was essential for research-related aid while others thought it should remain closely tied to Sida or at least until the impending investigation regarding Swedish aid was finished. This division was also clear in parliament on April 23 ${ }^{\text {rd }} 1975$ when the decision to instate a research aid organization was put to the vote. A majority of the parliament were positive to the instatement per se, but the conservative opposition was against the proposed independence. ${ }^{527}$ The division of opinion on the issue resulted in a tie of 158 to 158 (three did not vote). The vote then had to be re-done and resulted in Sarec becoming a temporary organization - awaiting the completion of an investigation on the organization of Swedish foreign aid.528 During the years 1975-1979, Sarec remained an advisory body to the government and Sida. During this time, Sida remained responsible for making major budgetary decisions. ${ }^{529}$

\section{Interpreting the task. The first annual reports.}

The government underlined two main reasons why they considered it important for Sweden to support development research and research cooperation: 1) the poor state of

\footnotetext{
${ }^{526}$ Ibid. p1

527 For a more detailed discussion about this, see Kjellqvist, T. (2013). Biståndspolitikens motsägelser om kunskap och tekniköverföring - från konkret praktik till abstrakt policy. doctoral dissertation series, Blekinge Institute of Technology. pp175-179

528 For details see (1975). Regeringens proposition med förslag till statsbudget för budgetåret $1975 / 76$

${ }^{529}$ Responsibility for budget decisions concerning development research in Sweden, however, was given to Sarec in 1977.
} 
research capacity in Third World countries (as low-income countries were then referred to as) and 2) the need to improve Swedish knowledge and understanding of low income countries. ${ }^{530}$ In the beginning, the general mandate of Sarec was to "to promote research which can support the developing countries ${ }^{531}$ in their efforts to achieve self-reliance and economic and social justice." 532

Furthermore, the purpose was to "...strengthen the role of research in development cooperation and to ensure that scientific competence is maintained when research projects are prepared and scrutinized."533 Sarec was also to advise the government and aid agencies about this research and cooperate with research councils and research organizations in preparing projects. ${ }^{534}$ Their task, in other words, encompassed several levels - to strengthen research capacity in low-income countries and mobilize Swedish researchers in this effort, to strengthen development research in Sweden, and to advise the Swedish government and Sida on issues relating to research. The task of Sarec was also related to the general aim of Swedish development cooperation, which was to "assist developing countries in the efforts to achieve a development which satisfies the basic needs of the people: for housing, clothing, education and human dignity." 535 In the process of interpreting the goals in the first annual report, Sarec summarizes the overarching focus of its operations for the first decade:

Sarec attaches priority to measures that will help the Third World countries to increase their own ability to carry out research and to accumulate knowledge needed for their development, and to mobilise Swedish researchers and research institutes in support of this endeavour to increase domestic capacity in Third World countries. ${ }^{536}$

When Sarec became an independent government agency 1979, it received a decree which did not differ significantly from the guidelines that had been in place previously. ${ }^{537}$ Throughout the first decade, it was often emphasized that it was Sarec's task to promote research that would "support the third world countries in their effort to achieve selfreliance, economic and social development and equality." 538 These statements reflected very clearly the idea that research aid should be "value-relevant." Similar statements were

\footnotetext{
530 Sarec (1977). Sarec's First Year, Annual Report 1975/1976. p18

531 There are a number of different terms used for low-income countries, though developing countries is the term most frequently used: Third World, poor, underdeveloped, South, and collaborating partner. The same variation exists for high-income countries: rich, wealthy, industrialized, developed, donor, technologically advanced, North, and Western.

532 Sarec (1977). Sarec's First Year, Annual Report 1975/1976. p18

533 Ibid. p18

534 Ibid.

${ }^{535}$ Sarec (1979). Sarec's Third Year, Annual Report 1977/1978. p25

536 Sarec (1977). Sarec's First Year, Annual Report 1975/1976. Regeringskansliet (1979).

Förordning (1979:832) med instruktion för styrelsen för u-landsforskning (Swedish Agency for Research Cooperation with Developing Countries, SAREC). Utrikesdepartementet.p1 537 Regeringskansliet (1979). Förordning (1979:832) med instruktion för styrelsen för ulandsforskning (Swedish Agency for Research Cooperation with Developing Countries, SAREC). Utrikesdepartementet.

${ }^{538}$ See for example Sarec (1977). Sarec's First Year, Annual Report 1975/1976. p18
} 
made regarding the importance of context-specific support based on the demands of the low-income countries.

The term capacity is central from the beginning in relation to Sarec's task, and research capacity 539 is the most frequently used term. It is defined in Sarec's first annual report and based on the definition by the Development Research Committee from 1973. This definition reappears throughout the first two decades, albeit with slightly different wording. Research capacity was seen to involve the following abilities:

- Ability to identify independently and define research tasks and their relation to the development problems and the development work

- Ability to plan and to carry out important research or to commission and direct such research which cannot be successfully tackled with domestic technological, financial, and human resources

- Ability to assess, choose, and adapt research results for domestic application

- Ability to offer the country's own research workers and environment that is sufficiently stimulating to counteract migration to technologically advanced countries

- Ability to disseminate and apply research results

- Ability (in terms of finance and staff) to utilize opportunities offered by international research cooperation and to take an active part in such cooperation. ${ }^{540}$

This attempt at defining what constitutes research capacity illustrates the complexity of the task at hand. Efforts were made to further specify and break down the purpose and overarching goals. This seems to have been easier to do concerning the support to Swedish development research since this measure consisted of funding research applications using the same process as the other Swedish research councils did. The reasons for supporting international research organizations were also quite clear, given that this kind of support had already been provided for over a decade when Sarec was created. The goals for support to low-income country research capacity, however, remained relatively vague for several years; they became more specific later on.

The early years included longer, critical and essay-like introductions situating the task of Sarec. Karl-Erik Knutsson, ${ }^{541}$ for example, writes in the 1976/77 annual report of the need to see both development and research in a more holistic way as opposed a series of separate compartments:

One of the most common and at the same time one of the most dangerous misunderstandings prevailing in the industrialized countries is that reality itself is only the sum of a number of separate and specialized "sectors". One is the "market"

\footnotetext{
539 Capacity and research capacity shows up in different variations in the annual reports:, domestic research capacity, domestic competence, innovative capacity, absorption capacity, research capability, national research capacity, endogenous science and technology capabilities, and institutional research capacity.

${ }^{540}$ Sarec (1977). Sarec's First Year, Annual Report 1975/1976. p15

541 The first director of Sarec, an anthropologist - whom also headed the committee on development research
} 
which is left to economists to study; another is the political sector (political scientists). Religion and law are two other such compartments in the Reality Room... [...] And if we, within the Western type of society which still is the dominating producer of science, scientists and scientific modes of thought - look outside the research community, we find the same pattern. ${ }^{542}$

The essence of what he is saying seems to be that the whole is more than the sum of all its parts and that the dominance of "Western" science is problematic because it is a proponent of sectorization and compartmentalizing. He goes on to claim that the negative consequences of these traits increase when research and researchers produced within this system are transferred to a different context - making it more likely that research is modelled on Western priorities (imitation) and not development-relevant:

In combination, such factors [imitation processes and lack of development relevance] together with dominant political and economic forcers - have generated a tremendously powerful transnational intelligence industry, of which the western research community and many of its branches in the third world are integrated parts. As many other multinationals - it imports raw material not least from the third world. Huge amounts of raw material in the form of students are processed and transformed into "intellectual Barbie-dolls" and re-exported, thus guaranteeing the successful continuation of center dominance and mimetic development strategies. $^{543}$

Knutsson makes it clear here that he adheres to the definition of development which is advocated in the Committee report from 1973 - a system of dependencies where the "Western" centres continue to dominate over the "Third World" peripheries. It is representative of the character of annual reports of the first few years - dominated by the localist discourse which at the time aligns itself with dependency theory and seeks to change the centre-periphery relationships by strengthening local research capacity.

\section{Modes of support: old and new priorities}

The Committee on Development Research had recommended that research efforts be problem-oriented, multidisciplinary, and value-relevant; that is, aimed at changing the conditions of underdevelopment. ${ }^{444}$ As with the task and goals, programmes, sectors and methods of work of Sarec became more clear and specific towards the end of the first decade. In the following section of the chapter, I will present the different ways in which Sarec's annual reports portrayed their programmes and methods of work and how priorities developed between 1975 and 1979.

During the first couple of years, Sarec worked on guidelines for research aid. They divided low-income countries into three groups with the purpose to identify need

\footnotetext{
${ }^{542}$ Sarec (1979). Sarec's Second Year, Annual Report 1977/1978. pp11-12

543 Ibid. p13

${ }^{544}$ Sarec (1977). Sarec's First Year, Annual Report 1975/1976. p14
} 
for collaboration and aid. ${ }^{545}$ It was stated that no country belonged definitely to one category, but the first group comprised countries that had no national policies dealing with science and technology for development. The second group of countries had development-oriented research policies but lacked resources. The third group of countries already had a certain level of development-relevant research capacity. Countries with characteristics like those in the second group were identified as having the best preconditions for Sarec support. ${ }^{546}$ This entailed that depending on how well developed the research capacity of a country, university or research area was - the support would be designed to match the need at hand - to either strengthen basic capacity through for example research training or to focus more directly on cooperation with development relevant results as the main goal.

During the 1970's, the annual reports relatively often highlighted the importance of ensuring that the cooperation was to be based on national priorities of the low-income country. Certain important sectors (in addition to, or instead of nationally defined priorities) were nevertheless identified quite early on:

\begin{abstract}
Sarec has established no special priorities among the sectors to which support for research is to be assigned. It is not possible to decide in advance and as a general principle whether to support a given branch of forest research or health research. [...] However, from the analysis of the developing countries' situation and in the effort to promote a development which satisfies basic human needs, certain sectors emerge as vital for research. ${ }^{547}$
\end{abstract}

The vital sectors were 1) health and nutrition research, 2) agriculture and rural development, 3) technology and industrialization, and 4) development theory and development economics. ${ }^{548}$ The first two sectors were given most funds during the first decade. How these sectors emerged was not discussed in detail. One could argue that the insistence on basing cooperation on national priorities is part of the localist discourse and the valuing of the "vital sectors" is more linked to the universalist discourse. The former assumes that knowledge cannot be legitimate or useful without being locally prioritized and produced, while the latter believes that knowledge can be relevant irrespective of the origin. The quote above exemplifies very clearly how the two lines of argument coexist in Sarec's policy.

\title{
International research programmes
}

This is the oldest form of support. Direct financial support was provided annually to for example the Consultative Group on International Agricultural Research (CGIAR), The World Health Organization (WHO) and various UN organizations. Sarec's rationale for supporting research in international organizations was inherited along with the method

\footnotetext{
545 Ibid. p26

546 Ibid. pp26-27

${ }^{547}$ Sarec (1979). Sarec's Second Year, Annual Report 1977/1978. p30

548 Ibid. p30
} 
of support itself; it made good use of scarce resources and the results would benefit the countries that were lacking in research capacity. The support was furthermore assumed to result in more generalizable findings, and it would facilitate undertaking research in areas that may not be considered politically acceptable in some countries. ${ }^{549}$ The reasons for supporting international organizations were universalist in the sense that the research findings were considered generalizable and applicable to many, if not all, lowincome countries. Sarec agreed with the "inherited rationale" but was also of the opinion that it could in fact inhibit the development of national research capacity in low-income countries:

\begin{abstract}
International and regional projects are sometimes used to preserve colonial influence, to establish neo-colonial dependence and to circumvent national priorities and country programmes. They may have the effect of delaying the buildup of national capacity, contributing to the emigration of researchers and distorting national investment. 550
\end{abstract}

Although the international research programmes were considered important and received a considerable portion of the budget throughout the entire period - critique of their work methods is present in almost all the annual reports. This is an expression of the pluralist discourse. Sarec consistently encouraged increasing the involvement of lowincome country researchers in the processes of planning and implementation of research projects in the international organizations. ${ }^{551}$ Sarec evaluated the international programmes during the late 1970's with the assistance of low-income country researchers. They concluded that the research by the international organizations was of high quality but often lacked in relevance in relation to the contexts of specific low-income countries. Furthermore, Sarec maintained that research results from the international research organizations were often difficult to absorb and use due to weak national research capacity in low-income countries. As a result of these conclusions, Sarec decided that more resources should be dedicated to strengthening national capacity in lowincome countries. ${ }^{552}$ Support to international research organizations nevertheless remained the largest budget post during the first decade.

\title{
Bilateral research cooperation
}

Bilateral cooperation was direct support to cooperation between universities in lowincome countries and Sweden with the main aim to increase the research capacity of the low-income country. Support in the beginning was provided mainly via research councils but also though support to projects and institutions depending on the existing research infrastructure. The agreements made during the late 1970's were with Sri Lanka, Tanzania, Vietnam, Zambia, Ethiopia, Botswana, Guinea Bissau, Mozambique, India and

\footnotetext{
${ }^{549}$ Sarec (1977). Sarec's First Year, Annual Report 1975/1976. p32

550 Ibid. p34

551 For example in Annual Reports 1977/1978, p39, 1978/1979, pp24-25, and 1979/1980, p30

552 Sarec Annual Report 1979/1980, Sarec, 1981, pp5-6
} 
Cuba. ${ }^{553}$ Most of the countries belonged to the category which Sarec determined as having very little research capacity at the time. The support was not intended for long-term projects to begin with because they were seen to risk creating dependencies. ${ }^{554}$ At the conference of Science and Technology for development in 1979, low-income countries demanded more long-term support. Sarec had changed position on the issue around the same time because it was seen as necessary to cooperate for longer periods of time in order to be able to build capacity. This mode of support was taking form at the time so the activities undertaken were in part experimentation. The intention of it, however, was illustrative of the pluralist discourse.

\section{Swedish development research}

This programme was undertaken in order to strengthen the development research capacity in Sweden and to increase Swedish researchers' interest and involvement in research on low-income country problems by reinforcing the funding available for development research provided by other research councils. This capacity and interest could then for instance be used in bilateral cooperation projects and as a resource for Sarec evaluations. These efforts were also seen to contribute to the internationalization of higher education and research in Sweden.555 Sarec used between 8 and $10 \%$ of its budget for this but pointed out that the main responsibility for this kind of research still rested with the universities and the other research councils. Sarec's research council function evaluated applications from Swedish researchers with the help of interdisciplinary groups. They accepted applications that could be classified as having to do with the vital sectors discussed above.556 If one assumes that the end goal is to contribute to development in low-income countries, this support is clearly more related to the universalist discourse. If one, however, considers Sarec's overarching task - it includes building Swedish capacity to do development-relevant research. It is not just results-oriented, but also geared towards building an ability to cooperate with lowincome countries.

\section{Regional cooperation and special initiatives}

Due to the relative isolation of many researchers in low-income countries, regional cooperation through networks was seen as the only realistic way to engage in research activities. This was most common in relation to the social sciences, where the isolation was much more common. This is another case where the two discourses can be seen to closely intertwine. The support is actually aimed at building local capacity but sees no other way to do so than to support regional networks for example. The capacity building efforts in regional cooperation and special initiatives are not tied to national institutions in the same direct way as in bilateral support.

${ }^{553}$ (1985). Tio år med Sarec. En utvärdering av SARECs verksamhet med särskild tonvikt på de bilaterala insatserna (Ds UD 1985:2). Utrikesdepartementet. p15

${ }^{554}$ Sarec (1979). Sarec's Second Year, Annual Report 1977/1978. pp21-22 \& p30

555 Sarec (1977). Sarec's First Year, Annual Report 1975/1976. p34-35

556 Sarec (1979). Sarec's Third Year, Annual Report 1977/1978., p43 
Below is a table with examples of activities undertaken within each mode of

support.

\begin{tabular}{|l|l|}
\hline Mode of support & Example activities \\
\hline $\begin{array}{l}\text { International research } \\
\text { organizations }\end{array}$ & $\begin{array}{l}\text { Support to the World Health Organization (WHO) for research on } \\
\text { human reproduction and the development of better contraception. } \\
\text { Support to the Consultative Group on International Agricultural } \\
\text { Research (CGIAR) for research on increasing food production in the } \\
\text { developing countries, focused on major cereals. Research on animal } \\
\text { husbandry and the economic and social aspects of agricultural } \\
\text { production was also done.557 }\end{array}$ \\
\hline Bilateral Cooperation & $\begin{array}{l}\text { Much of the cooperation was budding during these first years. Visits, } \\
\text { discussions and planning. Examples of actual projects include: } \\
\text { Cooperative archaeology project between University of Maputo in } \\
\text { Mozambique and Stockholm University. Support to the Tanzania } \\
\text { National Scientific Council (TNSRC), which began by establishing a } \\
\text { centre for scientific documentation and information with the help of a } \\
\text { Swedish expert. Research training cooperation with University of Dar } \\
\text { es Salaam and University of Lund was also going on.558 }\end{array}$ \\
\hline $\begin{array}{l}\text { Swedish development } \\
\text { research }\end{array}$ & $\begin{array}{l}\text { In 1977/1978, 89 Swedish development research projects were } \\
\text { financed by Sarec. The topic areas included were: Development theory } \\
\text { and social science research, technology and industrialization, } \\
\text { agriculture and rural development, health and nutrition and education } \\
\text { and communications. Social sciences dominated. 559 }\end{array}$ \\
\hline and special initiatives & $\begin{array}{l}\text { Support to social sciences and development theory through funding } \\
\text { research networks like the Latin American Social Science Council } \\
\text { (CLACSO) and the Council for the Development of Economic and Social } \\
\text { Research in Africa (CODESRIA).560 }\end{array}$ \\
\hline
\end{tabular}

\section{Renewed economist protest}

As a way to illustrate how some aspects of Sarec's founding years were perceived as controversial, I will return to sources like Economic Debate and others, where critique of Sarec was voiced from time to time. On the issue of Sarec's research priorities and budget allocations - economist Carl Hamilton wrote an article in 1977 which criticized them for leaning too much on the perspectives of Marxist, cross-disciplinary researchers, actively

557 Sarec (1979). Sarec's Second Year, Annual Report 1977/1978. pp23-25

558 Sarec (1979). Sarec's Third Year, Annual Report 1977/1978. pp32-34

559 Ibid. p43

560 Sarec (1979). Sarec Annual Report 1978/1979. pp38-39 
excluding economic perspectives. ${ }^{561}$ The occasion was a workshop in Västerhaninge (Sweden) in August 1977 on development theory and specifically cross-disciplinary research, although part of the debate included a question about the purpose of the meeting. Hamilton claimed that it was a meeting to discuss criteria for judging future research application, and he opposed the composition of researchers present:

The group was dominated by researchers who maintained that they represented a cross-disciplinary alternative perspective to other ("conventional"), first and foremost economic research. Those in the group who considered themselves economists has a historical-sociological, often Marxist, perspective on development problems. In other word, it was strongly underlined that it was important to study historic and social processes, mainly on a global level. Studies of specific internal problems, different underdeveloped countries internal conditions and preconditions were given less weight, if any at all! 562

Hamilton was very critical of how economists - and economics as an area of research were generalized, stating that the field was considerably more dynamic and context sensitive than the Marxist historians would have it. He maintained that the representation at policy-informing meetings had to mirror a wider group of subjects and perspectives, and that it was highly questionable to include people who also were applying for grants from Sarec. ${ }^{563}$ Knutsson's response was that it was not in fact a meeting to discuss criteria, and that it followed the recommendations put forth in the Investigation report from 1973, to follow the trends within this kind of research. He stated that there were several economists there, including Swedish ones, and also referred to a similar seminar planned for the year after, more focused on the field of economics. ${ }^{564}$ Regarding the issue of the focus on internal conditions, Knutsson stated:

On this issue I just want to point out, as a social scientist, that I do not understand how one can discuss processes of underdevelopment and development without also applying a historic, structural point of view. The statement that the group was not interested in internal, national problems is entirely untrue. Among others, representatives from the Association of Third World Economists underlined this especially. In general, one of the most important results from the meeting was the critique, from several directions, against the development theoretical debate up until now: namely that it has paid far too little attention to local and national problem variations. ${ }^{565}$

${ }^{561}$ Hamilton, C. (1977). Vem styr användningen av Sarecs forskningspengar? Ekonomisk Debatt, Nationalekonomiska föreningen. p382

562 Ibid.

563 Ibid. pp383-384

${ }^{564}$ Knutsson, K. E. (1977). Användningen av Sarecs forskningspengar. Replik till Carl Hamilton. Ekonomisk debatt Nationalekonomiska föreningen. p497

565 Ibid. p498 
Knutsson lamented that some researchers called neoclassical economics "conventional" but maintained that what was conventional in one field could be uncoventional in another. He gave the example of structuralist views of development and stated that it was conventional within anthropology and sociology, but not economics. Knutsson stated that neoclassical economic theory should be allowed "theoretical hegemony" on the topic of development. ${ }^{566}$ Hamilton replied and claimed that Knutsson did not answer his critique and that he mispresented many of his statements, insinuating that Swedish economists were narrow-minded and non-pluralistic. Hamilton upheld that he welcomed a diversity of perspectives and that that this was not the case in Västerhaninge. ${ }^{567}$

Both Knutsson and Hamilton used a polemic tone and made claims and statements that the other did not answer. Regardless of the details in this case, it is clear that Sarec irritated economists. Whether it was Sarec's explicit adherence to what was considered "alternative" perspectives at the time or something else is not possible to determine here. Either way, it is clear that they were both battling for their right to define and stake out relevant borders pertaining to the study of development.

\section{From research to development through aid}

The following section focuses more closely on the question of how Sarec in their annual reports construct the relationship between research and development. I start by following the arguments concerning the links and then proceed to discuss the discourses I have identified and tensions between then.

The annual reports contain various answers to the question of what the links between research and development are. The essence of the argument is the same, despite variations in formulation and emphasis: in order for a country to develop autonomously, there is a need for local/national capacity that can identify and produce the knowledge most suited to that particular context and problem. Coupled with this argument is also a more or less explicit critique of low-income country dependence on external capacity (often from high-income countries), which implies that low-income countries cannot escape "underdevelopment" without developing their own capacity in science and technology. The aid actor Sarec was constructed as a temporary facilitator. Research capacity was consistently portrayed as a prerequisite for development, but the more specific issue of what methods to pursue to best support the process of building capacity without promoting aid dependence was more complicated.

\section{Sarec as the context-sensitive and emancipatory donor}

The first few annual reports discussed at length the effects of colonialism and the current domination of Western science to argue for more demand-led cooperation based on lowincome country priorities. The domination of Western science and patterns of research is

\footnotetext{
566 Ibid. p499

${ }^{567}$ Hamilton, C. (1977). Slutreplik till professor KE Knutsson. Ekonomisk debatt, Nationalekonomiska föreningen. p500
} 
portrayed as a continuation of colonialism in a sense. ${ }^{568}$ Despite the recognition of the value of indigenous knowledge systems, many quotes and illustrations in the reports could be seen as upholding high income countries as the provider of the "right" kind of knowledge. The concept of indigenous knowledge systems does not return again in coming reports, and the discussion about the dominance of Western research is discussed in less explicit ways. Perhaps this is because the whole idea in a way would have undermined Sarec's very existence. Nevertheless, power relations in the world and control over resources are discussed frequently in the reports:

Advances in science and technology have contributed to the high material standard of living in industrialized countries. Resources for developing science and technology knowledge - and control over such resources - have a strategic importance. [...] External technological dependency makes it very difficult for developing countries to be self-reliant and to build up capacity for autonomous decision-making, and a capacity for generating and absorbing those elements of technical knowledge which suit their particular conditions. ${ }^{569}$

Science and technology capacity are seen to be necessary for independent and contextrelevant decision-making, which in turn is assumed to improve the possibility of the countries in question to reach their political and economic goals. ${ }^{570}$ Though statements surrounding research and development such as the one above may seem less controversial today, it is interesting to consider them against the backdrop of dominant development discourses during these decades. As illustrated by the debate between economists and other social scientists (in Economic Debate), the challenges surrounding development could be described in very different ways.

The annual reports contain clear ambitions to create modes of cooperation and support that are based on the prioritized needs as expressed by the low-income countries. The heterogeneity of low-income countries is often discussed; “... an awareness of the unique local conditions in each instance is crucial. It is important for Sarec to be able to "plug in" into many different systems." 571 The type of support offered by Sarec thus differed from country to country, though the general goals and principles remained the same. Sarec stated in its first annual report that "the fact that the needs of the third world countries govern the overall orientation of Sarec's support gives Sarec a special position in relation to other research funding bodies." ${ }^{72}$ This is another example of Sarec positioning itself as flexible and context-sensitive in relation to "others" (though no specific organizations are mentioned). Another example that illustrates the centrality of context in Sarec's reports is the discussion about the "situatedness of researchers":

\footnotetext{
568 Sarec (1977). Sarec's First Year, Annual Report 1975/1976. pp8-9

569 Sarec (1979). Sarec's Second Year, Annual Report 1977/1978. pp18 \& 40

${ }^{570}$ Sarec (1979). Sarec's Third Year, Annual Report 1977/1978. p26

571 Sarec (1981). Sarec Annual Report 1979/1980. p11

572 Sarec (1977). Sarec's First Year, Annual Report 1975/1976. p18
} 
Science is what scientists do, trapped as they are by their background, interests and the direct or indirect sponsors of their trade, not some independent reservoir of knowledge which gradually can be tapped. ${ }^{573}$

The individual researcher, in other words, is often constructed in much the same way as research capacity on an institutional or national level is during this period- as contextdependent. It assumes, in line with the localist discourse, that both history and present conditions affect what can be done, what is done, when, and by whom.

\section{Sarec as a temporary provider of priorities and expertise}

During the first years, the main form of support was still financial support to research in international organizations. Also, while the ambition of Sarec was to engage in demanddriven research cooperation based on the priorities of the low-income countries, there were - as discussed earlier - also certain areas that were prioritized as they were identified more pressing than others. Certain sectors were deemed as vital in terms of development relevance. Though the choice of these sectors may appear as "logical" from some sort of global perspective, it may be considered inconsistent in relation to the policy of basing the support to low-income countries entirely on their own priorities:

In order to promote development research and research cooperation, an organization having close contacts with the research community is required...at the same time...such an organization [Sarec] should ...endeavour to serve as a bridge between research and the practical implication of its results, between the "searching process" and the "implementation process". 574

Simplifying it a bit, Swedish expertise was to help fill the science and technology gap through acting as catalyzing experts in certain areas of research internationally deemed as development relevant. At some point, the low-income countries would become capacitated enough to do all parts of the research process on their own. Sarec portrays itself as a bridge.

\section{The boundary organization's conundrum}

The dilemma of priorities is not limited to the donor-recipient relationship; it is further complicated by the different goals that researchers and policy-makers have, as portrayed by the first annual report for instance:

Those who are themselves involved in research tend to emphasize the free, unplannable and innovative aspects and to stress the long-term usefulness of the research activity, while those who are not themselves engaged in research often put

${ }^{573}$ Sarec (1979). Sarec's Second Year, Annual Report 1977/1978. p14

574 Sarec (1977). Sarec's First Year, Annual Report 1975/1976. p9 
the emphasis on the goals, steering, planning and more immediately useful aspects of the same process..$^{575}$

Here, Sarec suggests that their task is not an easy one. It is not specified exactly which political principal they are referring to, it could be the parliament, the Ministry of Foreign Affairs or Sida for example; but it is a clear reflection of the pressures of combining two areas which are in several ways incompatible.

\section{Concluding discussion: discourses and tensions between them}

This chapter has shown that Sarec's research for development discourses are firmly based on a modern science model, often labelled as "Western". The role of the aid actor is portrayed as a catalyst and a bridge, a temporary facilitator of expertise. An ambition to play a more emancipatory role is restricted by path-dependence and the unequal relationship that characterizes "donor-recipient". It is further complicated by the different goals and roles of scientists and politicians and their respective political areas.

As I have already suggested, the first few years of Sarec's policy is characterized by the struggle between two main discourses - the universalist versus the localist discourse. These two discourses do not always stay neatly separate, they cross and blend in different ways but can nonetheless be identified with some consistency and each one can associated with a number other views as exemplified below.

\section{Universalist}

Development focuses on the present and the future. Economic growth is central.

The interests and priorities of HIC actors dominate

HIC actors as experts and catalysts. Not critical of aid actor role.

Universal knowledge and technology. Results in focus. Technology transfer. Absorptive capacity.

System important, but single factors are very significant.

Disciplinary research seen as superior. Some research less value-laden than others.

Modernization, neoclassical economics.

\section{Localist}

Development is conditioned by history. Multiple factors important.

The interests and priorities of LIC actors dominate

HIC actors as temporary facilitators. Critical of aid actor role.

Local production and development of knowledge and technology. Process in focus. Indigenous capacity.

Many factors important, the system

Cross-disciplinary research highly valued. All research is value-laden.

Centre-periphery models, dependency theory.

Modern Western science as model for development Local/national research capacity is necessary

Table 5: The discourses

575 Ibid. p10 
The table will be relevant for the following three empirical chapters as well. It is a simplification of course, but it enables an analysis of the complexity of the research aid actors' construction of science and technology for development. An important point to make here is that how one choses to conceive of the "development problem" has consequences for what kind of "solution" one strives for. Hence if one sees development as relatively universal and predictable, then it is not as logical to ask the question whether investment in a research council model is adequate in Mozambique for example. The context may still be considered important, but the context would be expected to adapt to enable the council rather than the other way around. A more localist view of development would be more likely to ask whether a science council is the best means to achieve the goals of research aid in that particular country and context.

An equally important point is that both views in this case stem from the basic assumption that regardless of definitions - modern science is important for development. Science as a solution is not questioned, even though the pluralist discourse to a larger degree actively reflects on the value of other knowledge systems. The two can be said to differ in the way they define central objects such as:

- The meaning of development.

- The kind of research considered most relevant for development

- The role of the high-income countries and aid actors

- How to build capacity

At times the universalist discourse emphasizes individual researchers as a more important part of research capacity while the localist discourse emphasizes enabling contextual factors like policy, infrastructure, and so on. Both, however, situate these as dependent on each other. The localist discourse also emphasizes the importance of local capacity and knowledge more than the universalist discourse, which tends to see knowledge as more universal and thus less dependent on being produced in the lowincome countries. According to this line of reasoning, support to international organizations is supported much more by the linear discourse than the systemic one which tends to favour national and regional support and bilateral cooperation.

It would be incorrect to simply say that the localist discourse was dominant during these first years, the two discourses rather appear as main branches stemming from the same trunk - as illustrated by the table above. Even though certain development theories can be associated with each discourse, they are both modernistic in the sense that Western research is the model for low-income country development, and they both have emancipatory ambitions in that low-income country self-reliance is a goal. The sociotechnical imaginary which characterizes the founding years of Sarec's policy envisions the low-income country with a self-reliant system for research that is not dependent on neither the aid actor nor Western research in general. The researchers identify their own problems, relevant to their context, and contribute to national development. Modern science is certainly questioned during the early years, but it nonetheless remains the model, otherwise one might claim that Sarec did not have a 
raison d'être. Scientific research is considered as a means to solve problems and control events, regardless of whether extended goal is to reduce poverty or increase economic growth, or both. Capacity building as a method can be seen as a unifying object.

It is clear that the boundaries between politics and science are being intensely negotiated during this period by Sarec and other actors. The dominant economic theories of development were challenged by dependency theory and other centreperiphery models, and Sarec positioned itself as supportive of the latter perspectives. Opinions were strong about what Sarec should do, why and how - from Sarec itself, Sida, researchers and evaluators. Boundaries between politics and science were also negotiated in the act of deciding which types of research to support. Medical sciences and certain natural and/or basic sciences were considered less political than social sciences for example.

\section{Entering an independent phase}

In 1979, Sarec became a free-standing state agency, based on a government proposition concerning the organization of Swedish foreign aid. ${ }^{576}$ The proposition underlined that Sarec was living up to the original intentions of the government and was starting to build important links between Swedish research institutions and their counterparts in lowincome countries. 577

The autonomy of Sarec was seen as vital, at the same time as continued close contacts and cooperation with Sida was seen as necessary given that research-related aid also formed part of Sida's bilateral programmes. ${ }^{578}$ The next chapter focuses on the 1980 's, which were rather different in character when compared to the first years. Sarec started its independent phase, was evaluated for the first time, and faced a different political and economic situation than at its start.

\footnotetext{
576 (1979). Proposition 1978/79:113 om riktlinjer för u-landsinformation och biståndets organisation m.m. Utrikesdepartementet.

577 Another state actor working with research-related aid was the Swedish Commission for Technical Cooperation (BITS) - set up in 1979 to promote technical cooperation between Sweden and middle-income countries Sarec, however, remained the main actor in efforts to contribute to development through research. See for example Annerstedt, J. and A. Jamison (1986). Science and Technology for Development - Scandinavian efforts to foster development research and transfer resources for research and experimental development to developing countries. UNESCO. p17

578 (1979). Proposition 1978/79:113 om riktlinjer för u-landsinformation och biståndets organisation m.m. Utrikesdepartementet.
} 


\section{KESEARCH COOPERA- TION IN Africa}

Bilateral research cooperation

SAREC support to bilateal mesarch copperation with stricat

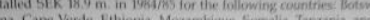
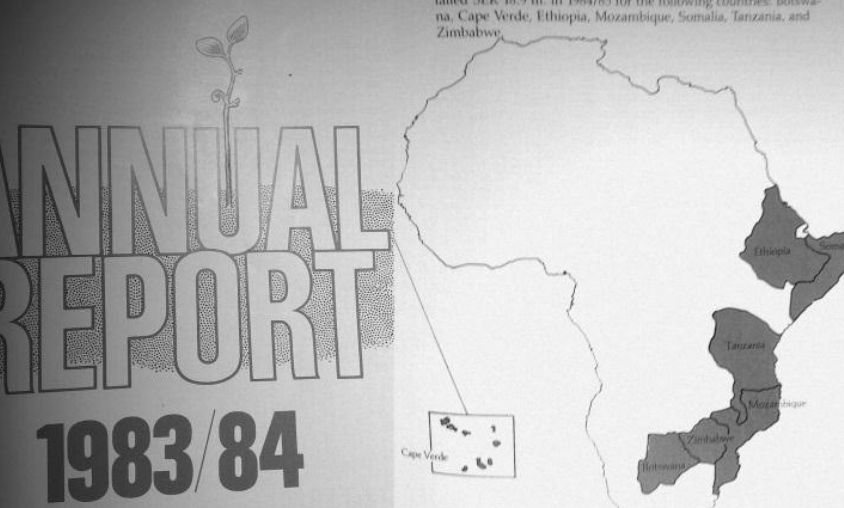

TABLE OF CONTENTS

Foreword

Introduction. The Evaluation committe and its Terms of Reference

SAREC - Ten Years of Activity. The Financial Development

The Changed Conditions for Research Assistance Perspective, SAREC's objectives, Sub-Targets and the Fulfilment of Targets
3

10

10

10

13

14

14

15

16

17

18

19

21

24

26

$2 E$

3.

3

3 Support to Developing Countries

The Development of Swedish Bilateral Research Support: The Cases Ethiopia Sri Lanka and Tanzania

Introduction

ETHIOPIA

Background

The SAREC Support

Some Priorities for the Future

SRI LANKA

Background

The SAREC Support

Some Conclusions

TANZANIA

The Research Situation

SAREC's Support

Some Conclusions

Other Bilateral Programmes

The Choice of Strategy - Analysis, Comments and Ideas

The Research Council Model

Research Training

Support to Research Infrastructure: Libraries and Laboratories Concentration

SAREC's Support in a Development

SAREC PिPOR 1

lapter 8

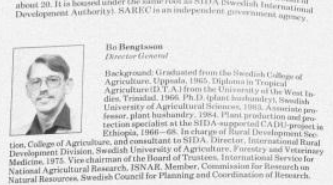

\section{SAREC - THE FIR}

An English Summary of the Report on the Swedish Age Co-operation with Developin "Tio år med SAREC - en SARECs verksamhet med to bilaterala insatserna"

UNCTAD The United Nations Conference for Trade and Deveciopment UNCTA De the Transfer and Development of Tetrinology aboul

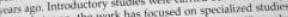
wivis Later on the work has which combine scientific analy with interpretation of results in the form of policy dations
The work is organised by the UNCTAD Technology Division. which has received SAREC support totalling (1977/75), the dustry (1980/81-1981/82), and the energy sctor (1052 and with 1963/84). The first two studies have bern compling eight the energy project five as well as a synthesis report. In the fiscal year 1924/85, SAREC allocald "The Fin that

Ds UD 1986: 1

\section{Ministry for Foreign Affairs}

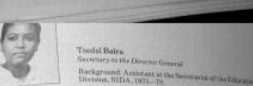

\section{Kerstin Ande
Serevitury}

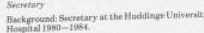

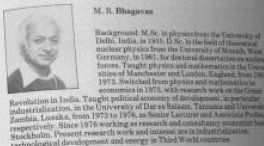

Paze

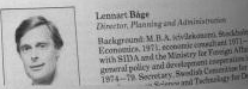

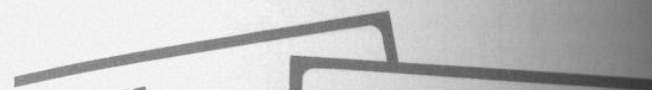




\section{1981-1990: Settling in and becoming pragmatic}

There were some controversies at Sarec earlier, among other things the decision to believe in a certain development paradigm - dependency theory. This created some gloom amongst economists. It was a mistake which I think we corrected. We as a scientific organization could not have such a definite opinion about certain research being right and other research being wrong - it is an impossible stance in relation to the scientific community. 579

- Former Director Lars Anell (1979-1983)

In its initial phase, during the still optimistic seventies, it was hoped that the programme would have dissemination effects and more and more [Swedish] researchers become interested in third world problems. This is not the way things turned out. In a harder economic climate horizons tend to shrink and what is immediately useful gets the upper hand. At several universities development researchers have become marginalized and now get drawn to the few hospitable institutions available. ${ }^{580}$

- Sarec annual report 1980-1981

The director in the quote above suggests that a boundary organization like Sarec simply cannot pay too much heed to the interests of individual scientific agents - in this case neoMarxist dependency theorists - it has to remain as neutral as possible. ${ }^{581}$ The second quote illustrates another, albeit slightly different break with the aspirations expressed during Sarec's first years. A harsher economic climate was seen to push Swedish development research into a more marginalized position. Man-made and natural catastrophes, inflation, unemployment and the arms race threat were some of the things the annual reports presented as obstacles for development in the low-income countries. ${ }^{582}$

Against the backdrop of financial crises across the globe in the 1980's, foreign aid in general was criticized for being inadequate in several ways. ${ }^{583}$ According to the editors Christian Andersson (radio editor and former employee at the Ministry of

\footnotetext{
${ }^{579}$ Transcription (2010). Interview with Lars Anell 032210. p1

${ }^{580}$ Sarec (1982). Sarec Annual Report 1980/1981. p42

${ }^{581}$ Anell's response was to a question about the most important changes during his time at Sarec.

582 See for example Sarec (1980). Sarec Annual Report 1979/1980. p5, Sarec (1984). Sarec Annual Report 1983/1984. p5, Sarec (1988). Sarec Annual Report 1987/1988. p6, and Sarec (1989). Sarec Annual Report 1988/1989. p6

583 Some examples of Swedish publications on the issue are Andersson, C., L. Heikensten, et al. (1984). Bistånd i kris. En bok om svensk u-landspolitik, Liber förlag. and Rydén, B. (1984).

Bistånd under omprövning, Studieförbundet Näringsliv och Samhälle.
} 
Foreign Affairs) and economists Lars Heikensten and Stefan de Vylder, the goal to provide $1 \%$ of GDP for foreign aid was questioned during this time; could Sweden afford it? Solidarity and low-income country interests took a backseat to "more efficient aid."584 Neoliberal ideologies dominated the agendas of many economically influential countries, entailing a strong faith in markets, trade liberalization and privatization. ${ }^{585}$ Sweden moved closer to the middle of the OECD countries in terms of policies, which emphasized macroeconomic structural adjustments and debt relief. The Brundtland commission report Our Common Future was published in 1987 and environmental consideration was included in a new Swedish aid goal in 1988.586

In Sweden, how science was being steered was criticized, as was the situation in universities, ${ }^{587}$ and the OECD took a few steps back in relation to the instrumental view of scientific knowledge:

Society, and governments, have a valid claim upon the expertise in the university, but to turn the university into a centre primarily of applied research is an abuse and a misuse of that expertise (OECD 1981:35 cited in Blume 1985:157).588

Research politics in Sweden during the late 1970's and early 1980's focused on breaking the "sector principle", democratization and steering of research towards usefulness changed somewhat, in favour of more autonomous decision making for the universities. According to Elzinga and Jamison, this was a reflection of the dominating ideology of the time and the economic policy culture that went along with it. ${ }^{589}$ The research bills of the 1980's underlined the importance of research for staying internationally competitive as well as for national development, and sector agencies were turned into research councils. 590

A relatively pessimistic view dominated regarding both the poorest countries' potential to benefit from aid and Sida's ability to deliver this aid given the goals and methods. ${ }^{591}$ At the same time, according to Sarec, the interest from low-income countries in science and technology policy was on the increase due to the UN Conference

\footnotetext{
${ }^{584}$ Andersson, C., L. Heikensten, et al. (1984). Bistånd i kris. En bok om svensk u-landspolitik, Liber förlag. p7

585 Odén, B. (2006). Biståndets idéhistoria: från Marshallhjälp till millenniemål. Lund,

Studentlitteratur. pp95-96

586 Ibid. pp101-102

${ }^{587}$ Benner exemplifies with reference to Elzinga, A. and B. Wittrock (1985). The University Research System. The Public Policies of the Home of Scientist, Almqvist \& Wiksell International. p194 where Elzinga introduced the concept of epistemic drift to illustrate that the flexibility of university had been tested to its limits; scientific criteria and quality were being destroyed. ${ }^{588}$ Benner, M. (2008). Kunskapsnation i kris. Politik, pengar och makt i svensk forskning, Nya Doxa. p30

${ }^{589}$ Melander, F. (2006). Lokal forskningspolitik. Institutionell dynamik och organisatorisk omvandling vid Lunds universitet 1980-2005, Lund University. pp124-125

590 Ibid. pp129-130

591 The so-called " $1 \%$ goal" not least; the idea that $1 \%$ of the annual state budget was to go to foreign aid. See for example Rydén, B. (1984). Bistånd under omprövning, Studieförbundet Näringsliv och Samhälle. pp16-17
} 
on Science and Technology for Development in 1979.592 Towards the end of the decade, the number of Swedish universities engaged in research cooperation with low-income countries increased greatly. In other words, the preconditions for research aid seemed mixed.

In relation to the founding years, Sarec's policy development in the 1980's can in general be characterized as more strongly aligned with the universalist discourse discussed in the previous chapter. Elements of the localist discourse remain clearly present, however, and the branches could be said to overlap a bit more in this decade. Sarec's role as a boundary organization is tested; they were forced to defend the importance of research for development in general and to re-evaluate their modes of work in particular. As the title suggests, becoming pragmatic and showing results are characteristic for this time period.

The purpose of this chapter is to explore how Sarec's research for development discourses evolve during the 1980's. How are universities and researchers seen to contribute to development and what is the role of the aid actor in this process? These questions are explored with the help of the 10 year evaluation, annual reports and two interviews. The 10 year evaluation is discussed relatively early in the chapter because its critique and recommendations make for interesting contrast to the other materials. There is a shift in the policy in the middle of the decade which will be clearer with the 10 year evaluation as background.

\section{Attempting to construct a more pragmatic and concise task}

Sarec's official task after 1979 (when it became an independent agency) in essence remained the same as it was before: "to promote research which can facilitate increased self-reliance in developing countries as well as economic and social justice".593 The annual reports of the 1980's, however, are characterized by somewhat more concise and pragmatic interpretations, such as:

...to support developing countries in their endeavours to strengthen their research capacity. Or to put it in more quantifiable terms; Sarec aims at helping developing countries increase the number of qualified scientists who are able to work under reasonable conditions. ${ }^{594}$

The interpretations are not surrounded by as much questioning, and the "whys" are not elaborated on in as much detail. Formulations can generally be interpreted as less valueladen than those of previous years. Sarec considered some development problems which required large amounts of money as being outside their reach. ${ }^{55}$ They could, however,

\footnotetext{
592 Sarec (1981). Sarec Annual Report 1979/1980. p10

593 (1979). Förordning med instruktion för styrelsen för u-landsforskning (Swedish Agency for Research Cooperation with Developing Countries, SAREC). 1979:832. Riksdagen. Svensk författningssamling. punkt 2

594 Sarec (1983). Sarec Annual Report 1981/1982. p5

595 Sarec (1985). Sarec Annual Report 1983/1984. pp5-6
} 
help the low-income countries to increase the number of qualified researchers and to improve the environments in which they operated in certain ways. By the middle of the decade, the interpretation of the overarching task was as follows:

\section{...to assist third world countries}

- to build up a national research capacity comprising research environments of good quality, education and training of national scientists, methods for planning and setting priorities for research and allocation of resources for these purposes.

- with financial and scientific resources with the purpose of providing research results in problem areas of great importance to developing countries and of transferring available research results of significance to their development

- to promote scientific contacts and, when needed, create scientific collaboration with research institutions in Sweden or other countries. 596

As for the definition of research capacity and its relation to development, it remains essentially the same as well, but it is broken down into more concrete details. Improved research capacity was said to enable independent and nationally relevant problem solving. It was also seen as enabling better use of internationally available knowledge and as contributing to the quality of higher education. ${ }^{597}$ Well-functioning research is portrayed as essential in a country's ability to use its resources efficiently: "To a large extent it is the level, quality and organization of scientific and technological skills that decide how well a country can make use of all other resources, e.g. labour, land, capital and natural resources." 598 The efficient use of resources had not previously been raised as quite so central. Discussing in terms of efficiency can be associated with a more narrow definition of development, including an emphasis on economic growth.

\section{The 10 year evaluation: questioning models and measures}

The first large review was published in 1985 and covered all of Sarec's activities as well as its policy. It was conducted by professor Carl-Gösta Widstrand (then based in Ottawa, Canada), Dr.Olav Stokke (then at the University of Oslo), Karl-Erik Norrman (councellor, the Ministry of Foreign Affairs) and professor Göran Hydén (then based in Nairobi, Kenya). It focused on the bilateral cooperation in particular, and it was based on three country visits (Sri Lanka, Tanzania and Ethiopia) as well as previously conducted internal evaluations. ${ }^{599}$ The review was sent out for consideration to around 70 authorities, research institutions and organizations. Low-income country actors and partners were provided with an English summary the year after, and it was also discussed 1986 at an international seminar in Sigtuna, Sweden. ${ }^{600}$

\footnotetext{
596 Sarec (1986). Sarec Annual Report 1984/1985. p11

${ }^{597}$ See for example Sarec (1983). Sarec Annual Report 1981/1982. p5

598 Sarec (1984). Sarec Annual Report 1983/1984. p6

${ }^{599}$ DsUD1985:2 (1985). Tio år med Sarec. En utvärdering av SARECs verksamhet med särskild tonvikt på de bilaterala insatserna Utrikesdepartementet. pp4-6

${ }^{600}$ Sarec (1988). Sarec Annual Report 1987/1988. p5
} 
During the first decade, Sarec considered national research councils to be the best entry point for starting research cooperation. This was because they were assumed to be able to articulate the country's research priorities. This was criticized by the evaluators, who were of the opinion that though the intention was well-grounded, many of the countries did not in fact have well-functioning research councils. ${ }^{601}$ Sarec's solution to this was to encourage and initiate the creation of research councils, something which the evaluators considered highly problematic:

We have no objection to the philosophy behind the choice of strategy. It is important that priorities should be designed by the recipient countries. It is, however, a paradox that the very concept of research support is, to a large extent, the result of donor priorities, since donors rather than recipients have given a priority to research as such as a necessary precondition for development... ${ }^{602}$

The evaluators put forth that research in developing countries was very much modelled on Western standards and often dependent on foreign support and advice. ${ }^{603}$ They claimed that the idea of a research council pursued by Sarec was modelled on Swedish research councils, which had quite a different organization and different tasks compared to the research councils being built in some of the low-income countries. For example, a research council in a low-income country may need to have responsibility for and knowledge about all the research going on in a country, whereas Sweden had several councils, some of which only had to deal with certain limited subjects or one sector. ${ }^{604}$ They objected to creating new levels of organization and bureaucracy in settings where it would not necessarily fill the same purpose as in Sweden. Instead, they recommended that Sarec negotiate directly with research institutions where possible. ${ }^{605}$ Universities were seen as more capable of creating continuity and more direct support to them was also considered a better way to support democracy and national identity. ${ }^{606}$ Cooperation with African institutions was considered an especially high priority given that the research capacity had deteriorated due to economic and other crises. ${ }^{607}$

Other conclusions of the 10 year evaluation were that support to research training was considered successful and should be continued, and that support to research infrastructure like libraries and laboratories should also be emphasized more. ${ }^{608}$ The evaluators recommended a slight concentration of activities, but the division of funds between thematic areas was considered relevant (medical and agricultural research received one third each of the budget, and other areas received the remaining third). ${ }^{609}$

\footnotetext{
${ }^{601}$ DsUD1986:1 (1986). Sarec - The First Decade, The Ministry of Foreign Affairs. pp27-28

${ }^{602}$ Ibid. p27

${ }^{603}$ Ibid. pp6 \& 10

${ }^{604}$ Ibid. pp27-29

${ }^{605}$ Ibid. pp12-14

${ }^{6} 06$ Ibid. pp12-14

${ }^{607}$ Ibid. pp38-40

${ }^{608}$ Ibid. pp32-35

${ }^{609}$ Ibid. pp36-37
} 
Support to international organizations was not to be reduced further, they claimed, since it was considered an important part of Swedish foreign affairs. At the same time, the evaluators said that this was not just the responsibility of Sarec - cooperation with different authorities and even other Nordic countries could assist in maintaining these important and necessary relations. ${ }^{610}$ They recommended the reorganization of the system for supporting Swedish development research to stimulate long-term development of research capacity through increased support to research environments instead of just individual researchers. ${ }^{611}$

With regard to whether and how Sarec was fulfilling its objectives, the evaluators maintained that it was ambitious and commendable to attempt to measure and account for results of aid to research given the difficulty of such a task:

...progress in science is closely linked to mechanisms that are similar to concepts like success and "greatness" in artistic activity. To take a drastic example we may well ask: What is an effective piano concert? Can we measure its efficiency in a meaningful way? Probably not. ${ }^{612}$

The evaluators concluded that Sarec seemed to have been fulfilling their targets well, but they also stated that there were many external factors which affected how results come to be, and that measuring quality was more difficult than quantity. ${ }^{613}$ While it was perceived as a good thing to attempt to follow-up, the bigger picture does not lend itself to detailed control. The evaluators' comments and recommendations are largely reflective of the localist discourse, downplaying the significance of single factors and highlighting the system together with basing activities on local conditions. In light of this, too closely copying the Western science system was not desirable.

\section{Evolving modes of support and priorities}

Sarec was now an independent agency and its budget was steadily increasing. The effects of decisions made in the 1970's together with new priorities as a result of experience and various evaluations together led to significant shifts in Sarec's methods and priorities during the 1980's. For instance, bilateral support went from next to nothing in 1976 to taking up $23 \%$ of the budget by 1984, and support to international organizations decreased from $93 \%$ to $49 \%$ of the budget during the same period. ${ }^{614}$ Support to regional cooperation increased from about $2 \%$ to $15 \%$, and Swedish development research was allocated around $8.7 \%$ from having been around just $3 \% .615$ The money spent on social sciences was reduced while the focus on health, natural sciences and technology

\footnotetext{
610 Ibid. p55

611 Ibid. pp61-63

612 Ibid. p45

613 Ibid. p45

${ }^{614}$ DsUD1985:2 (1985). Tio år med Sarec. En utvärdering av SARECs verksamhet med särskild tonvikt på de bilaterala insatserna Utrikesdepartementet. p18 615 Ibid.
} 
increased. In relation to the differences in priorities during the 1980's when compared to the 1970's, former director Bo Bengtsson (1983-1992) maintains that Sarec wanted to diversify their activities and deliver results:

There was some criticism regarding a few of the activities we started in the 1970's, there was a corruption issue in the Latin American Program which we had to sort out for example. This influenced our working procedures. Things got more concrete and at the same time, support to social sciences was reduced and the balance between subject areas became more even. ${ }^{616}$

During my time, there was probably more focus on contributing to results. For example, the cholera vaccine, the way of managing healthcare, research on sexually transmitted diseases and maternal health. It affected a national process in that it raised issues that were important to think about.617

The modes of support - or programmes as they were called - were divided into four different kinds and all of them were seen to contribute to building research capacity in different ways ${ }^{618}$ (bilateral research cooperation, research cooperation between developing countries and special projects, international research programs and Swedish development research).

Since the overarching purpose of Sarec's activities was to contribute to the development of "endogenous" research capacity, the annual reports underscored that all the modes of support needed to be coupled to low-income country efforts and needs in some way. ${ }^{619}$ The focus was on assisting in building capacity on a broad scale - from individual research training to research policy and planning - but to transfer already available research results was also a part of their task. This latter fact seemed troublesome for Sarec in some respects, since aiming for capacity or results implied different strategies as well as different views of knowledge and development. This clash of discourses, as one might call it, is visible in both the documents and the interviews.

In the annual report from 1982/1983, for example, Sarec states that the international organizations conduct research systematically and efficiently, they produce results which are then available for dissemination. Sarec maintained, however, that they were not primarily interested in "fish distribution" (disseminating general results) but rather in "fishing instruction" (support to national capacity building). ${ }^{620}$ Without their own capacity, the low-income countries would not be able to tackle their basic development problems nor would they be able to make relevant local use of internationally produced knowledge. Though there were several reservations to international organization research, for example, Sarec still saw it as strategically important to support both results and capacity building. This was partly because certain

\footnotetext{
616 Transcription (2010). Interview with Bo Bengtsson 101011.p3

617 Ibid. p9

${ }^{618}$ Sarec (1981). Sarec Annual Report 1979/1980. p12

${ }^{619}$ Sarec (1985). Sarec Annual Report 1983/1984. p6

${ }^{620}$ Sarec (1984). Sarec Annual Report 1983/1984. p12
} 
research deemed important (on vaccines for instance) demanded a sizeable amount of resources which would take time to build up in low-income countries. They saw the two approaches as "mutually reinforcing." 621 This strategy is illustrative of the fact that Sarec construct both a universal and a localistic research for development discourse. The sociotechnical imaginary that this combination would seem to entail includes a partial continued dependence for the low-income countries on external research results.

Sarec's response to the conclusions in the external 10-year evaluation - as portrayed in the annual reports - did not raise the issue of research councils in the same critical way that the evaluators did. These details, however, were included in the English version published by the Ministry of Foreign Affairs in 1986 which was made available to - and discussed with - Sarec's partners in low-income countries. Sarec maintained that that it was important to be able to vary their "point-of-entry" from country to country, but direct support to universities and their departments gradually became more prevalent at the end of the decade. ${ }^{622}$ Research training and individual project support remained an important method of support, but Sarec noted that several other donor organizations engaging in research aid focused on individual research projects and research training at the expense of the long-term endogenous capacity building process at research environments in low-income countries. ${ }^{623}$ They claimed that in order for research training for individual scientists to contribute to research capacity in low-income countries, cooperation efforts should focus on the needs of entire institutions. In relation to how the different modes of support worked together, Sarec portrayed itself as having a sort of palette to choose from:

The principle of Sarec has been to develop a mode of cooperation which is flexible enough to be adapted to the specific conditions of each country... an awareness of the unique local conditions in each instance is crucial. It is important for Sarec to be able to "plug in" into many different systems. ${ }^{624}$

Sarec's support was portrayed like a flexible piece that could be made to fit any puzzle essentially. Theoretically, according to this reasoning the uniqueness of each country determined which modes of support were relevant and pursued. Despite the flexibility described here, some "base resources" were to be financed by the "recipient country"; salaries and administrative costs for example. 625

Below is a table which illustrates some of the activities Sarec financed and engaged in. The aim has been to include projects from all continents where Sarec was active, and to reflect the various different kinds of activities going on under the umbrella of research aid. The descriptions tend to be lengthier/more detailed in the first half of the

621 Ibid.

622 See for example Sarec (1988). Sarec Annual Report 1987/1988. pp5-7 and Sarec (1989).

Sarec Annual Report 1988/1989. p6

${ }^{623}$ Sarec (1984). Sarec Annual Report 1983/1984. pp6-7

624 Sarec (1981). Sarec Annual Report 1979/1980. p11

625 Sarec (1983). Sarec Annual Report 1981/1982. p6 
decade, whereas the second half is characterized by much more concise descriptions. ${ }^{626}$ Interesting to note is that the support did not just involve actors like research institutes and universities but also government agencies, hospitals, organizations and private companies. ${ }^{627}$ Interests, knowledge and expertise from a wide variety of actors were represented.

\section{Mode of support Example activities}

Bilateral Cooperation Joint research programme with India on the production of oil seed (mustard and rape seeds) to stimulate the increased consumption of edible oil. Research, research training and equipment. Some of the actors involved (changed during the decade): The Indian government's Department of Science and Technology, the Swedish Seed Association, Uppsala University, Karlshamns oljefabriker, the Royal Institute of Technology (KTH), Swedish University of Agricultural Sciences (SLU). 628

Support to bilateral projects on botany, history, medicine (like diarrhoea and hepatitis) and energy and policy planning in Ethiopia. Researcher exchange visits, design of research programmes, support to master's and $\mathrm{PhD}$ training programmes. Some of the actors involved: The Ethiopian Science and Technology Commission, Addis Ababa University, Alemaya University of Agriculture, the Ethiopian Water Works Construction Authority, Gothenburg University, Uppsala University, University of Umeå, The Beijer Institute, and the Karolinska Institute. ${ }^{629}$

Support to bilateral projects in Tanzania such as agriculture research projects on local nitrogen-fixating trees, health research projects focused on Malaria and AIDS for example, scientific training of women (in veterinary medicine, forestry and agriculture) and livestock feed research. Equipment support, research training, research exchanges. Some of the actors involved: University of Dar es Salaam, Sokoine University, The Tanzania Ministry of Natural Resources and Tourism, Tanzania Ministry of Finance and Planning, Uppsala University, Swedish University of Agricultural Sciences (SLU), The Swedish Department of Forest Site Research, University of Umeå, Chalmers University of Technology, and University of Gothenburg. ${ }^{630}$

${ }^{626}$ Swedish development research, for example, is only presented as a mode of support in several years of the decade, without any practical examples of the research itself. ${ }^{627}$ Apart from the examples in the table, see the support to Nicaragua and Somalia in Sarec (1983). Sarec Annual Report 1981/1982. pp22-25

628 This cooperation went on during the whole decade, but see for example Sarec (1983). Sarec Annual Report 1982/1983. p22 and Sarec (1984). Sarec Annual Report 1983/1984. pp23-24 for more detailed information.

${ }^{629}$ See for example Sarec (1983). Sarec Annual Report 1982/1983. pp19-20 and Sarec (1989). Sarec Annual Report 1988/1989. pp27-28

${ }^{630}$ See for example Sarec (1987). Sarec Annual Report 1986/1987. p19 and Sarec (1989). Sarec Annual Report 1988/1989. pp32-33 


\begin{tabular}{|c|c|}
\hline & $\begin{array}{l}\text { Bilateral cooperation with Cuba on water pollution, plant diseases, zoo- } \\
\text { hygienic research, technical and scientific information, breast cancer } \\
\text { research and Hodgkins disease research. Some of the actors involved: } \\
\text { Instituto de Oncología y Radiobiología (INOR), the Cuban Institute for } \\
\text { Hydroeconomy, National Centre for Agrarian Health (CENSA), Cuban } \\
\text { Academy of Sciences (IDICT), the Royal Institute of Technology (KTH), } \\
\text { Karolinska Instutite, Gävle Hospital Department of Mammography, } \\
\text { Swedish University of Agricultural Sciences (SLU), Environment Group } \\
\text { AB, and Swedish Air Pollution Research Institute (IVL).631 }\end{array}$ \\
\hline $\begin{array}{l}\text { Research cooperation } \\
\text { between developing } \\
\text { countries and special } \\
\text { research projects }\end{array}$ & $\begin{array}{l}\text { Support to regional research council CODESRIA (The Council for the } \\
\text { Development of Social Science Research in Africa) - economic and social } \\
\text { research. It had } 56 \text { members in } 28 \text { African countries in 1984. Sarec } \\
\text { funded together with the Canadian IDRC and the Ford Foundation.632 } \\
\text { Support to AAWORD (the Association of African Women for Research } \\
\text { and Development) - activities to improve the status of women and } \\
\text { transforming gender relations in African societies. Areas like women } \\
\text { and reproduction, women and employment, feminism in Africa and } \\
\text { feminine roles in the mass media.633 } \\
\text { The LAP (Latin American Programme). Grants to regional and national } \\
\text { research institutions in the area of social science such as CLACSO (El } \\
\text { Consejo Latinoamericano de Ciencias Sociales) a social science research } \\
\text { council, and CIDE (Center of Development and Education Research, } \\
\text { Chile). The grants were seen to contribute to independent and critical } \\
\text { research in contexts which were sometimes repressive.634 } \\
\text { ISP (International Science Programs, earlier called the International } \\
\text { Seminars in Physics and Chemistry) at Uppsala University. Started in } \\
\text { 1960. Basic research training, } 30 \text { stipends awarded annually to low- } \\
\text { income country researchers.635 } \\
\text { IFS (International Foundation for Science in Stockholm). By 1984, for } \\
\text { example, } 935 \text { low-income country scientists from } 82 \text { countries had } \\
\text { received stipends enabling them to do research in their home countries } \\
\text { on applied biology and agriculture.636 }\end{array}$ \\
\hline
\end{tabular}

${ }^{631}$ See for example Sarec (1985). Sarec Annual Report 1983/1984. pp19-20 and Sarec (1986). Sarec Annual Report 1984/1985. p31

${ }^{632}$ Sarec (1984). Sarec Annual Report 1983/1984. p36

${ }^{633}$ See for example Sarec (1983). Sarec Annual Report 1982/1983. p35 and Sarec (1984). Sarec

Annual Report 1983/1984. pp35-36

${ }^{634}$ See for example Sarec (1989). Sarec Annual Report 1988/1989. pp 20 \& 53

635 See for example Sarec (1988). Sarec Annual Report 1987/1988. p39

${ }^{636}$ Sarec (1986). Sarec Annual Report 1984/1985. p40 


\begin{tabular}{|c|c|}
\hline $\begin{array}{l}\text { International research } \\
\text { organizations }\end{array}$ & $\begin{array}{l}\text { WHO (the World Health Organization) Research on human } \\
\text { reproduction, mother and child health, tropical diseases } \\
\text { CGIAR (Consultative Group on International Agricultural Research) } \\
\text { Founded by the FAO and the World Bank in } 1971 \text { with the purpose of } \\
\text { improving food production in developing countries through research. } \\
\text { Research institutes are located in many parts of the world. Research on } \\
\text { for example cultivation systems, rice varieties, livestock production, } \\
\text { drought resistance and improvement of protein quality in wheat and } \\
\text { barley.637 } \\
\text { UNRISD (the United Nations Research Institute for Social } \\
\text { Development). Focused on global issues related to the achievement of } \\
\text { UN development goals, such as the improvement of development data, } \\
\text { research on food systems and food security, refugee issues and urban } \\
\text { development.638 }\end{array}$ \\
\hline $\begin{array}{l}\text { Swedish development } \\
\text { research }\end{array}$ & $\begin{array}{l}\text { Problem areas supported were: Development theory and social science; } \\
\text { Technology and industrialization; Agriculture and rural development; } \\
\text { Health and nutrition and Education and communication } \\
\text { Examples of topics that received funding: } \\
\text { - Soil-organic nitrogen dynamics-changes in tropical rainforest } \\
\text { soil } \\
\text { - Food-production of locally available biomass and of traditional } \\
\text { - pseudo-cereals } \\
\text { - Tropical diseases, diarrhoea } \\
\text { - Cultural aspects of development such as music, modernity and } \\
\text { - the communication of a national identity in Nepal. } \\
\text { - Housing and building techniques } \\
\text { - Patterns of technology transfer } \\
\text { - Water supply } \\
\text { - Desertification and land degeneration } 639\end{array}$ \\
\hline
\end{tabular}

${ }^{637}$ See for example Sarec (1984). Sarec Annual Report 1983/1984. pp41-43 and Sarec (1989). Sarec Annual Report 1988/1989. p59

638 Sarec (1984). Sarec Annual Report 1983/1984. p47 and Sarec (1988). Sarec Annual Report 1987/1988. p41

${ }^{639}$ Sarec (1981). Sarec Annual Report 1979/1980. pp36-39 and Sarec (1986). Sarec Annual Report 1984/1985. p45 
The support to Swedish development research (about $8 \%$ of the budget) was expected to produce development relevant results but also to increase the number of researchers willing and able to participate in bilateral cooperation with low-income countries. Towards the end of the decade, and seemingly as a result of the 10 year evaluation, support was not only given to individual researchers but also to research environments and research groups. 20 environments or groups and 100 individual research projects were given support in 1988 for example. 640

Environmental issues found their way onto the political agenda in the late 1980's. A special environmental goal was also added to the goals for Swedish foreign aid in 1988, something which Sarec claimed made clear that environmental issues needed to be integrated within all aid programmes instead of being a "sector" of its own. ${ }^{641}$ Sarec presented all the environment-related projects they already had, but also stated that they would increase their efforts in the area. This would affect the sociotechnical imaginaries in Sarec's policies, but environmental issues were not particularly central until the early 1990's. In the mid-1980's, the 10-year evaluation was published, and the Swedish parliament passed a bill which included a proposal that a comprehensive research programme be initiated on the problems of desertification and deforestation. Half of the proposed budget was to go to Sarec and the other half to two Swedish national research councils. ${ }^{642}$

\section{The battle to define development problems and their solutions. Part 2: converging ideas?}

As mentioned earlier, as part of this study I have also tried to identify critique of Sarec for each decade. During the 1970's and 1980's, the journal Economic Debate is one such place where this kind of material was found. It is interesting to present some of this critique since it provides historical context and it assists in nuancing the discussion about research aid discourses. This time around, there was no visible debate, such as the one during Sarec's founding years, but it is nonetheless an interesting set of opinions to highlight.

Cross-disciplinarity as a way to combat development problems more efficiently was not underlined as strongly in Sarec's policies during the 1980's, but statements like "development research must be inter-disciplinary in nature" 643 could still be found. Mats Lundahl wrote in 1981 about the role of theory in development economics and posed the question whether or not inter-disciplinary studies were useful. ${ }^{644}$ To make a long story short, he gives examples from both traditional and Marxist economic theory and concludes that while uncritical use of either tradition is risky, it is not worth totally discarding one or the other:

\footnotetext{
${ }^{640}$ See for example Sarec (1990). Sarec Annual Report 1989/1990. p67

${ }^{641}$ Sarec (1989). Sarec Annual Report 1988/1989. pp7-8

${ }^{642}$ Sarec (1987). Sarec Annual Report 1986/1987. p7

${ }^{643}$ Sarec (1988). Sarec Annual Report 1987/1988. p6

${ }^{644}$ Lundahl, M. (1981). Teorins plats inom utvecklingsekonomin. Ekonomisk Debatt, Nationalekonomiska Föreningen. 8, ibid. pp607
} 
As unjustifiable as it would be to just transfer our common Western models of thought to the underdeveloped countries, it would be equally meaningless to throw the baby out with the bathwater, that is, to automatically - without reflection discard all "traditional" forms of economic analysis. ${ }^{645}$

Development economics, he states, was by that time no longer only focused on economic growth but also on the distribution of resources and employment issues, the theories and the methodological toolbox had been diversified since the 1950 's. ${ }^{646}$ He maintains that one should be sceptical of certain mathematical methods and grand theories that are not specific enough to be flexible and useful, yet one should also avoid getting bogged down completely in un-generalizable results. ${ }^{647}$ Useful inter-disciplinary research needs an economic base, he maintains, to be able to analyze how the distribution of resources plays in. ${ }^{648}$ Arne Bigsten argues in a similar vein (in 1984) about the role of theory in development economics, stating that grand theories were long gone (such as Rostow's stage theory), that dependency models were not that successful either, and that a certain convergence of ideas (structuralist, neoclassical and even Marxist) could be observed at the time. ${ }^{649}$ This makes sense in light of the development theory diagrams in chapter 1 of this book for example, which show that during the 1980's - both the ideas of neoliberalism and human development were influential.

Lundahl returns in $1985^{650}$ and examines in greater detail the crossdisciplinary approach to studying development - again underlining the centrality of an economic framing. ${ }^{651} \mathrm{He}$ maintains the fact that there are different kinds of disciplinary combinations (multi-, cross- and inter-disciplinarity) that can be used to tackle development problems and concludes that they can indeed be useful. Multi-disciplinary research in this case is two or more disciplines providing their perspectives on a problem without integrating methods or theories. Inter-disciplinarity involved such integration, theories or methods were more combined to shed new perspectives on the problem. Cross-disciplinarity was somewhere in between. Lundahl does not consider the cross- or inter-disciplinary option as optimal or efficient because it presumably requires too much knowledge of each field and demands a lot of resources in itself. In other words, multidisciplinary efforts would be the most efficient and useful, according to him. Furthermore, Lundahl claims that because development economics and other, more socially oriented, sciences were very far down on the hierarchy of and within disciplines, more crossdisciplinarity risked making development research classified as second-rate. "Good"

\footnotetext{
645 Ibid. p608

646 Ibid. p612

647 Ibid. p608

648 Ibid. p210

${ }^{649}$ Bigsten, A. (1984). Ekonomisk utveckling i fattiga länder. En teoriöversiktibid. 1. pp26-34

650 With an article that was based on a presentation at a Sarec seminar in Båstad, Sweden in

September 1984. Lundahl was also a part of Sarec's board

${ }^{651}$ Lundahl, M. (1985). Bör utvecklingsforskningen vara tvärvetenskaplig? Ekonomisk debatt, Nationalekonomiska föreningen. 2. p141
} 
researchers would tend to choose disciplinary work, in other words. ${ }^{652}$ His solution to this problem was for Sarec to ensure that all cross-disciplinary projects undertaken were held to high international standards. 653654

Since "cross-disciplinarity" is not raised consistently in the annual reports, it is unclear how many of Sarec's projects were considered as such, but the articles above can be seen as a snippet of the academic discourse on development theory in relation to Sarec's operations. This discussion also mirrored the national discussions on science policy and the usefulness of research which were going on at the time. ${ }^{655}$

\section{Bilateral cooperation as a way to build national capacity}

One of the main conclusions concerning international organization research from the late 1970's and early 1980's was that problems stemmed from "an inadequate understanding of the situation in which the problems arose and in which the research results were to be applied." 656 Sarec maintained, furthermore, that the weak link in the global science and technology system was the national level in low-income countries and its "weak integration with the domestic system." 657 In other words, there may have been a research council but it did not have well-functioning cooperation with universities or the government for example, or vice versa. This conclusion remained intact through the 1980 's and was one of the reasons given for why bilateral support as a method to support national research capacity increased.

Towards the middle of the decade, it was the mode of support which Sarec upheld as the most central way to contribute to building endogenous capacity. After the 10 year evaluation, the focus on Africa increased significantly, and mostly through bilateral cooperation. ${ }^{658}$ Sarec cooperated with 14 countries by then, and around one fourth of Sarec's budget was allocated to this kind of support. By 1988, 80 Swedish research departments were involved in bilateral cooperation of some kind, and Sarec considered it an efficient way to meet urgent needs as well as create a base for long-term capacity development. ${ }^{659}$ In countries with "more developed" research capacity - like Cuba and Argentina - the cooperation was mainly aimed at producing results.

An important part of the bilateral cooperation was research training, which came to be known as the "sandwich model" - where researchers from low-income country universities did field research in their home country but spent between 1 month and two

\footnotetext{
652 Ibid. pp143-146

653 Ibid. pp146-147

${ }^{654}$ There was no reply from Sarec, but he had presented this article at a Sarec seminar the year before.

${ }^{655}$ See for example the discussion in Benner, M. (2008). Kunskapsnation i kris. Politik, pengar och makt i svensk forskning, Nya Doxa. Chapters 1 and 7 on the issues of applicable versus basic research, sector science and usefulness.

${ }^{656}$ Sarec (1981). Sarec Annual Report 1979/1980. p5

657 Ibid.

${ }^{658}$ See for example Sarec (1988). Sarec Annual Report 1987/1988. p5 and Sarec (1989). Sarec

Annual Report 1988/1989. p6, and Sarec (1990). Sarec Annual Report 1989/1990. p6

${ }^{659}$ Sarec (1990). Sarec Annual Report 1989/1990. pp6-7
} 
years (usually up to 4 four months) in Sweden for training and collaboration. 500 researchers visited Swedish institutions in 1988, and 400-500 Swedish researchers visited their counterparts in low-income countries.660 According to Bengtsson, the Swedish universities were chosen if and when they were "demanded, competent, and willing to work according to developing country premises". ${ }^{661}$ From a foreign aid perspective, this was not common practice. The discussion on tied versus untied aid was well under way, but aid tended to be designed in order to benefit the donor countries where possible.

Towards the end of the decade, bilateral cooperation was diversified and expanded when compared to previous years. Cooperation remained highly project-based and agreements often included research training. Actors receiving support were research councils, university departments and various types of research institutes. More institutionally oriented support was provided to some of the countries, including support to entire departments and library support.662 This institutionally oriented support increased as the decade drew to a close, perhaps indicating a strengthening of the localist discourse's perspective on how capacity building was best achieved. Individual training and specific projects were still considered essential, but a wider type of support was seen as necessary to contribute to the long-term sustainability of research institutions. It also - at least theoretically - implied that the low-income country actors were given greater freedom in decisions concerning allocation of resources. Attempts to create more locally based research training programmes could be considered a step in that direction as well.

\section{Essential versus luxury research}

The annual reports underlined that despite the difficulties of predicting results in research, it was important to develop concrete criteria for evaluating and following up the impact of this aid, in order to justify the investments being made. ${ }^{663}$ In response to a question about what kind of research was seen as relevant for development, Bengtsson maintained that it was not unusual to have to defend the idea that research could help the poor. One way of explaining how research was not a luxury, he said, was to present concrete results:

...many people said that research does not help to solve problems in the developing countries. Yes it can, I said, but you have to show that results are achieved as well. I worked to show that development research, conducted in the right way, can lead to results. 664

\footnotetext{
${ }^{660}$ Sarec (1989). Sarec Annual Report 1988/1989. p6

661 Transcription (2010). Interview with Bo Bengtsson 101011. p6

662 See for example Sarec (1987). Sarec Annual Report 1986/1987. pp19-20, Sarec (1988). Sarec

Annual Report 1987/1988. pp16-17, Sarec (1989). Sarec Annual Report 1988/1989. pp27-29

${ }^{663}$ Sarec (1985). Sarec Annual Report 1983/1984. p12

664 Transcription (2010). Interview with Bo Bengtsson 101011. pp2-3
} 
At the same time, he maintained, concrete results did not imply that just applied research was relevant: "Good research is problem solving research. Whether it is basic or applied depends on which phase the research is undertaken." 665 Defence of the role of research was also common in the annual reports:

...research capacity is also a prerequisite for effective use of factors of production. In this sense, research capacity is perhaps the scarcest of resources. Therefore, development of endogenous resources within science and technology can never be seen as a luxury that has to give way to pressing short-term priorities. 666

Often, the necessity of research capacity was defended with reference to the inadequacy of knowledge and technology transfer where no attention is paid to contextual differences. Basic needs and research are not seen as mutually exclusive priorities. Without knowledge, they maintain, there will be no precondition for action. Science and technology was to be seen as a dimension of society. 667

Research results and techniques obtained in other, more developed, countries are often not applicable and the problems to be solved not the same. It is sometimes argued that research is a luxury commodity in a country where the basic needs of the majority of the population are not yet satisfied. This argument, however, is not valid even in a short-term perspective. The most important prerequisite for action is knowledge, and so the developing countries must both be given access to existing relevant knowledge and enabled to acquire such knowledge on their own. ${ }^{668}$

Research is portrayed as essential in enabling a country to use its other resources efficiently and independently, something which should be out-crowded by other shorter term priorities. Bengtsson maintains that Sarec at the time was focused on broadening its areas of support. The support to relatively marginalized areas during Sarec's first years nevertheless had positive effects, though they were perhaps controversial at the time:

..one of the areas of support was Samir Amin's network on the negative effects of colonialism and how industrialized countries dominated the developing world. His research was acknowledged because it received international support. It was a way to help get in "on the agenda", even though it was controversial to finance it, not least as seen by the Swedish parliament at the time. Another example was women's research. It was unusual to give money to something run entirely by women, and in Africa too. It showed the importance of highlighting different activities and effects related to gender, and it became very well established eventually. ${ }^{669}$

\footnotetext{
665 Ibid. p2

${ }^{666}$ Sarec (1982). Sarec Annual Report 1980/1981. p5

${ }^{667}$ Sarec (1985). Sarec Annual Report 1983/1984. p6

${ }^{668}$ Sarec (1986). Sarec Annual Report 1984/1985. p5

${ }^{669}$ Transcription (2010). Interview with Bo Bengtsson 101011. p9
} 
I argue that this can be seen as part of the localistic discourse as it emphasizes the potentially positive effects of research on democratic processes as a goal. Research aid is not tied to development results as a short-term primary goal. The sociotechnical imaginaries that this might entail involve independent research capacity as an enabler of democracy, including the visibility of marginalized perspectives. The 10-year evaluation discussed these marginal areas of support in the context of being projects that received "risk-money":

...SAREC - particularly during its first years had to pay a certain amount of "riskmoney" for a number of projects, some of which may not have been successful. We think, anyhow, that it may have been worthwhile to pay this "risk-money" and that SAREC's "midwife activity" is useful both for recipients and the Secretariat. ${ }^{670}$

Exactly how they have been useful is not discussed, but it is mentioned in a section that discusses the need for Sarec to consolidate and concentrate their activities somewhat. In other words, they saw the value of such investments (similarly to Bengtsson, above), but suggested that it was too much work to manage many smaller projects. This is something that was raised by later directors as well in relation to the support for regional organizations.

The emphasis on results becomes even more prominent in the annual reports after the 10year evaluation. More space is dedicated to presenting countries and thematic areas and corresponding projects, and staples and diagrams are used much more to illustrate priorities and financial distribution. ${ }^{671}$ Efforts were also made to reach the Swedish public with the results being produced. In 1990, Sarec published a report called Knowledge that creates change (Kunskap som förändrar).

Bengtsson's introduction (see image to the right) very explicitly addresses "tax payers", and explains how a seemingly insecure type of aid investment indeed produces results of great value to the low-income countries. ${ }^{672}$ It goes through examples from all the thematic areas (health, rural development and the environment, natural sciences and technology, and social sciences and the humanities). It also discusses briefly how Sarec operated, its' goals, programme areas and modes of

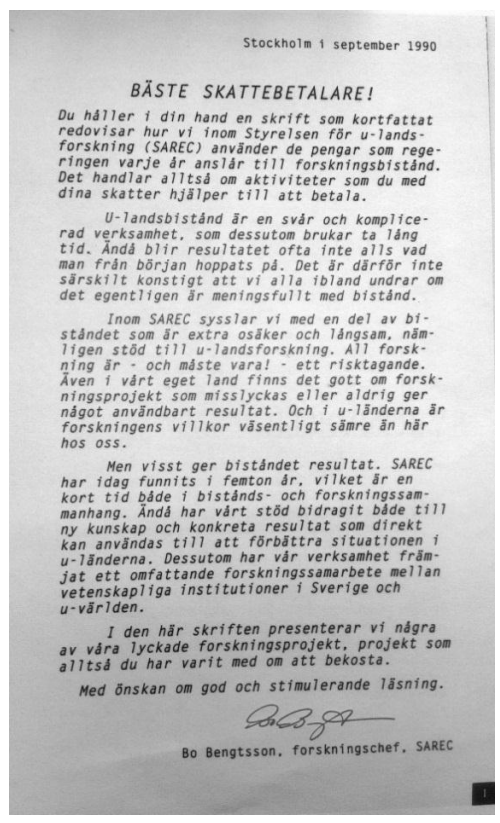

\section{Figure 5: Knowledge that creates change}

\footnotetext{
${ }^{670}$ DsUD1986:1 (1986). Sarec - The First Decade, The Ministry of Foreign Affairs. p45

671 Sarec (1988). Sarec Annual Report 1987/1988. pp10-11

672 Fruhling, P. (1990). Kunskap som förändrar. Resultat av forskningsbiståndet, Berlings. p1
} 
support. It is reflective of the need to defend research as an area in aid. It explains concretely the many benefits that could be achieved with this kind of support, enabled by Swedish tax payers.

\section{The critical and context-sensitive aid actor}

As I mentioned in the beginning, pragmatism characterized the 1980's, and even though self-critique was not as prevalent during the 1980's, it was far from absent. In the beginning of the decade, Sarec made it a point that it was crucial to always be ready to "question and redefine its activities". ${ }^{673}$ As I discussed earlier, the practice of traditional technology transfer as a development method (coupled with a linear view of innovation) still remained strong among aid actors worldwide during the 1970's and 80's despite being heavily criticized. Sarec positioned itself against this approach:

It is an illusion to view technology as embodied in capital equipment which would make it a commodity to be imported and ready to use. Technology is part of its native organisational culture with its network of directorial responsibilities, maintenance system, level of education and structure of incentives. ${ }^{674}$

A context-sensitive view of technology is promoted here; they maintain that its function is dependent upon the system of which it is part. Transfer of technology is problematic, Sarec maintains, even when "stages of development" are similar, and for low-income countries it can be especially difficult. ${ }^{675}$ As support to infrastructure was becoming more relevant and common, Sarec seemed to embrace a somewhat cautious approach in its policy. In relation to laboratory equipment, for instance, they stated that old and modern equipment were often mixed, resulting in quite great contrasts. Without adequate surrounding infrastructure, Sarec maintained, this was not meaningful - research capacity would "not increase just by buying a new piece of equipment". 676

During the early 1980's, Sarec frequently underlines the need to see research, technology and development problems from a systemic perspective, where social, economic and technical aspects all play a role. They do so not least when comparing themselves to other donors:

Often, third world countries are faced with the problem of combining gifts of scientific equipment of a range of makes from various donors. Usually, this results in an even more complex laboratory structure than at a Western research institution. 677

\footnotetext{
${ }^{673}$ Sarec (1981). Sarec Annual Report 1979/1980. p11

${ }^{674}$ Sarec (1984). Sarec Annual Report 1983/1984. p6

675 Ibid.

676 Sarec (1985). Sarec Annual Report 1983/1984. p10

677 Ibid. p13
} 
In other words, inadequate foreign aid can result in low-income country laboratories with an incompatible and much too diversified equipment collection which cannot be appropriately maintained. This, Sarec implies, is clearly not support which is based on the low-income country priorities. Instead, "step-by-step betterments within the existent infrastructure" 678 are needed.

In a similar critical fashion, Sarec reinforces the importance of context in relation to their own role. Science and politics are portrayed essentially as opposites, and Sarec is struggling in the middle - an explicit example of the tricky place of boundary organizations. Sarec states explicitly in the 1982/1983 report (referred to below) that they are a government agency and that this means they have objectives defined by political superiors.

Sarec is placed at the intersection of the scientific community with its clear cut priorities and dislike for financial constraints and the democratic polity with its general objectives and obligation to set limits. ${ }^{679}$

This, they argue further, implies that they do not just prioritize amongst research areas, but that they are held accountable to the goal of building research capacity. ${ }^{680}$ Sarec actively reflects on their role as a boundary organization and the challenges that this can entail. They talk about the difficulty of having a "domestic context" while their main task relates to responding to the priorities of low-income country governments and universities. ${ }^{681}$ They also tie this discussion to the challenge of basing aid on low-income country priorities, something which I will return to below.

The critical aid actor is also visible in relation to the support of large international research organizations such CGIAR, the WHO and the UN - a method of support which Sarec inherited from Sida and the Ministry of Foreign Affairs. The fact that a high proportion of the budget went to international organizations in the beginning of Sarec's existence was justified by the fact that they enabled resource concentration. Furthermore, research problems were considered regional or global in nature; hence international organization research was an efficient and well-functioning means to an end.682 This support, however, was something Sarec was supposed to change, given that the results were not seen as relevant enough to low-income countries and given that the international organizations lacked adequate points of cooperation with the low-income countries. ${ }^{683}$ The international organization perspectives were sometimes portrayed as flawed from the outset, since the research priorities were set from a high-income country perspective.

\footnotetext{
678 Ibid.

${ }^{679}$ Sarec (1984). Sarec Annual Report 1983/1984. pp9-10

680 Ibid. p5

${ }^{681}$ Ibid. p9

${ }^{682}$ Sarec (1981). Sarec Annual Report 1979/1980. preface

683 Ibid., p6
} 
Almost all significant research programmes, even those sponsored by UN agencies, were created by scientists from the North. Thus the research programmes designed to solve Third World problems, WHO's research programme on human reproduction (HRP) or the Consultative Group for International Agricultural Research (CGIAR), are based on how American and European scholars perceived the problems of developing countries. ${ }^{684}$

Sarec conducted evaluations of the international organizations with the goal to improve their low-income country relevance. In the quote below, Bengtsson is referring to these evaluations:

They irritated a lot of people internationally, I got very angry letters. Nobody had criticized them like that before, and it reflected the views of the developing country researchers. But then we as an organization got a relatively good reputation since we didn't just criticize, we came with suggestions for changes and improvements. ${ }^{685}$

Sarec remained active in improving the development relevance of the research and increasing connections to low-income country capacity building. ${ }^{686}$ It is not least manifested through the repeated commitment to voicing the opinions of low-income country researchers. The consulting with a network of "third world scientists" on Sarec's policy development is portrayed as essential: "without the commitment of these people, SAREC would gradually lose its sense of purpose and direction". ${ }^{687}$ The critique remained, but by the mid 1980's, Sarec maintained that the international organizations had begun cooperating much more with low-income countries, and the flaws of this kind of support are not discussed as much in the latter half of the decade. 688

Given, however, that Sarec's task according to their annual reports was heavily focused on building endogenous research capacity - and increasingly so as the decade progressed - it is relevant to point out that half of Sarec's budget still went to international research organizations. The international organizations were - and are very diverse in their make-up, modus operandi and locations. Some are in low-income countries and others are in high-income or middle-income countries for example. Though the percentage of the budget to this post did not increase, the amount of money to international organizations in fact continued to increase as Sarec's total budget did. Whether this was an effect of path dependence, political decisions, or other reasons, is not possible to answer in this context. It is, nevertheless, an interesting fact to point out since one could reasonably view support to international organizations as contributing significantly to high-income country research capacity as well as international research priorities rather than local capacity and low-income country priorities.

\footnotetext{
${ }^{684}$ Sarec (1984). Sarec Annual Report 1983/1984. p7

685 Transcription (2010). Interview with Bo Bengtsson 101011. p4

${ }^{686}$ See for example Sarec (1985). Sarec Annual Report 1983/1984. p6

${ }^{687}$ Sarec (1981). Sarec Annual Report 1979/1980. p6

${ }^{688}$ Sarec (1984). Sarec Annual Report 1983/1984. p7
} 


\section{Questioning agenda-setting while setting the agenda}

Sarec clearly and repeatedly underlined the importance of research aid being based on the priorities of the low-income countries. At the same time, as we saw in chapter 5 , they saw it as necessary to question and reconsider how these priorities were set; since they were not always easily defined by the cooperating partners either.

Most countries, whether developed or developing, do not have clear-cut lists of priorities indicating the priorities accorded different projects. The important thing, however, is that SAREC funds are used for projects which are regarded as highly important by the planning authority as well as the researchers. ${ }^{689}$

It is a seemingly open discussion about the potentially problematic process of setting the agenda; Sarec stated that international priorities tended to be translated uncritically to national priorities. There was often a need for discussion between the low-income country actor and Sarec regarding the feasibility of the priorities. To this effect, Sarec would also sometimes suggest specific areas of research, which could then be accepted by the "cooperating country." These suggestions, however, were to be made with caution to ensure national relevance and adequacy, according to the annual reports. ${ }^{690}$ In 1984, Sarec maintained that the rhetoric surrounding priorities is misrepresentative of the practice.

The priorities of developing countries", is probably, in fierce competition, the most misused phrase in the vast field of development rhetoric. It, or words to the same effect, is written into the aid legislation of almost all donor countries, but it comes out very differently in practice. ${ }^{691}$

Sarec also criticized other donors, maintaining that long-term capacity building processes need to take time, not least in the beginning stage when priorities and preconditions are established: "very often international donors are impatient and tend to rush the process. The donor wants to run faster than is actually in the interest of the participating country and scientific community". ${ }^{692}$ So one might wonder how Sarec saw themselves in this respect; were they also misusing the rhetoric? In response to a question about the issue of priorities, Bengtsson maintained that while they absolutely had the ambition of basing all support on local priorities, it was also a question of current resources for example, whether the country in question had the capacity at that time to do the kind of research they wanted. Things had to be negotiated. In some situations, international or Swedish priorities came to be more central:

\footnotetext{
${ }^{689}$ Sarec (1982). Sarec Annual Report 1980/1981.p6

${ }^{690}$ Ibid. p7

691 Sarec (1984). Sarec Annual Report 1983/1984. pp9-10

${ }^{692}$ Sarec (1981). Sarec Annual Report 1979/1980. p6
} 
Well we shouldn't do research for them, they have to do research for themselves. We can help with money and ideas or discussion, but it's their decision. That's why I was somewhat against how fast the institutional cooperation developed (towards the end of the decade) because sometimes dominant priorities may have been chosen (within the bilateral cooperation between Swedish universities and lowincome country universities) and tested in developing country contexts. ${ }^{693}$

According to Bengtsson, "dominant" priorities were sometimes used despite ambitions to the contrary, a priority-dilemma which is also raised in the annual reports:

There will never be a lasting societal consensus on any neat hierarchy of scientific priorities. But this is a problem only for those with a yearning for perfect solutions. In the real world of second-best solutions we know that tradition, on-going research programmes, existing centres of excellence, perceptions of future problems and political aspirations fuse into a pattern of resource allocation between broad areas of research. It cannot be defended with rigorous logic, but it works. ${ }^{694}$

The picture that Sarec paints here of how priorities are set is complex and messy, and it portrays a relatively pragmatic attitude. They also seem to adhere to the idea that perceptions about the future (ideas about future problems and political aspirations, see quote above) play into how resource allocation pans out. The annual report covering $1982 / 1983$ discusses the various pleas and attempts to underline the importance of particular research areas, like population research or energy research for example. The report argues that similar pleas could essentially be made for all sciences, but that financial aspects need to be taken into account and that the most important aspect for low-income countries is self-sufficient research capacity. ${ }^{695}$

\section{More politics than science?}

Adding to the list of factors affecting the construction of research aid, Sarec had several principals that both directly and indirectly steered their priorities. One of Sarec's strengths, according to Anell (director 1980-1983), was its ability to make choices about project support based on scientific criteria rather than political considerations:

We could say no to things that did not maintain high enough quality scientifically. When Sida said no, it was a political issue. We could handle the no in a much easier way. 696

Using scientific criteria is portrayed as being more straightforward than needing to consider political issues when deciding whether or not to provide support to certain projects. The focus on low-income country priorities in Sarec's support to building

693 Transcription (2010). Interview with Bo Bengtsson 101011. p9

${ }^{694}$ Sarec (1984). Sarec Annual Report 1983/1984. p9

${ }^{695}$ Sarec (1983). Sarec Annual Report 1982/1983. pp8-11

${ }^{696}$ Transcription (2010). Interview with Lars Anell 032210. p3 
research capacity, argued Anell, enabled independent problem solving as opposed to delivering ready-made solutions. ${ }^{67}$ Sarec sometimes had to argue against the use of predefined priorities by the parliament for instance:

It is the problems of the low-income countries that have to steer things. We have encouraged them to formulate a program on which we can base cooperation, and that program has to be the point of departure. 698

The discussion about scientific versus political criteria in the annual reports were not so explicit, but at the end of the decade, in 1988, Sarec received a new decree which removed the word "self-reliance" and tied the definition closer to Swedish foreign politics: "SAREC has as its task to strengthen underdeveloped countries' capacity for research and to promote such research that can contribute to development in line with the goals of Swedish foreign politics." 699

Around the same time, in 1989, a new national research bill was presented which described Sarec as being "...an aid agency first and foremost, with the task of promoting research which can facilitate underdeveloped countries' development..."700 The bill states that the responsibility for development-related research activities is not only Sarec's. It mentions the Nordic Africa Institute (NAI), Sida and the Bureau of Investment and Technology of Sweden (BITS) as other actors who engage in research in relation to low-income countries. Furthermore, the bill makes clear that while Sarec supports some Swedish development related-research, the general education system and the universities had the greatest responsibility for developing knowledge in this area. ${ }^{701}$

The research bill tries to spread the responsibility for development research widely, implying that is not just an aid-issue, it is in the interest of other actors - research councils and Swedish universities for example - to engage in these topics on their own accord. Later research bills are not as detailed in its discussions about development research, but during the 1980's, there is a clear push towards more university engagement in development issues.

\section{Concluding discussion}

Sarec experiences pressure from both principals and agents during this decade. External evaluators essentially accuse them of being neocolonial through the insistence on creating Swedish-relevant research infrastructure in order to build capacity instead of analyzing what is adequate in each setting. As the bilateral cooperation mode of support grows, Sarec sometimes has to mediate between Swedish researchers and low-income country researchers in order to minimize the effect of the inequalities. Two important political

\footnotetext{
${ }^{697}$ Ibid. p2

698 Ibid. p2

${ }^{699}$ (1988). Förordning (1988:532) med instruktion för styrelsen för u-landsforskning (SAREC).

D. o. F. Affairs. point 1

700 (1990). Regeringens proposition 1989/90:90 om forskning. p114

701 Ibid. p115
} 
principals - the Ministry of Foreign Affairs and the Ministry of Education tied Sarec's task more closely to the goals of Swedish aid in general, framing them as a political actor above all. Sarec, however, upheld the scientific nature of their work as their biggest strength, continuing to distinguish itself from aid in general for example. These were not necessarily incompatible framings, but they show that there were slightly different conceptions of Sarec's role.

The sociotechnical imaginary which seems to characterize the 1980's is one where the universities in low-income countries have enough researchers to conduct development relevant research in a wide variety of areas, teach and engage in international collaboration. Researchers also help to ensure that the countries' resources are used efficiently. Towards the end of the decade, universities are portrayed as necessary for all countries. This view suggests that research is a national endeavour where results are also used for national progress. At the same time, the annual reports underline that research transcends borders and cannot be nationally steered. With this view, research and its results are to a large degree international. This is not a surprising tension in the sense that research has been, and still is, based in national settings while networks and international collaboration form a central part of the work. This is reflected in Sarec's modes of support and strategies, which aim to cover different kinds of research. The different modes of support - aimed at capacity building and/or producing results can be partly coupled to certain views of how knowledge affects development, and these views continue to exist side by side.

The universalist discourse takes the upper hand - not least during the second half of the decade. There is greater emphasis on "global" priorities for research, and the importance of Swedish expertise. Economic growth is also increasingly mentioned as an important goal for development. The localistic perspectives remain present and strong, however, and Sarec retains clear emancipatory ambitions and underlines the importance of self-reliant research systems with nationally-based priorities that serve democratic development. Sarec in essence continues to marry a strong faith in modern Western science with a commitment to improving the influence of low-income country voices.

\section{Heading towards the 1990's}

As the 1980's came to an end - there were many big changes under way affecting the preconditions for research aid. The cold war ended for example, and world aid politics would change significantly as a result. Environmental problems and issues of sustainable development climbed high up on the agenda, and Sweden was preparing to enter the European Union. 

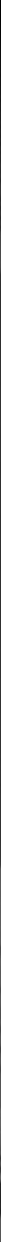

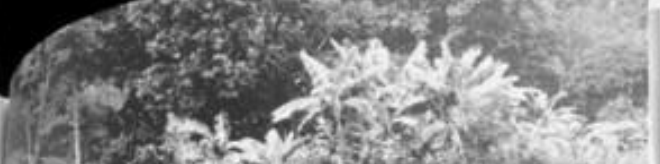

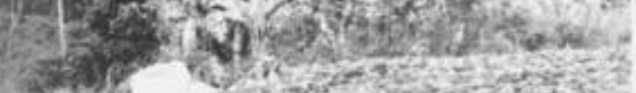
4.

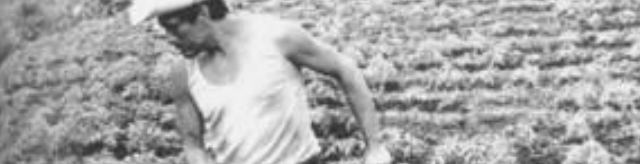

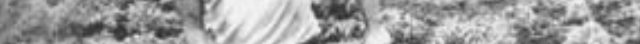

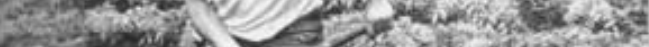

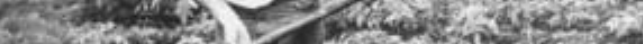

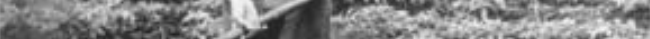

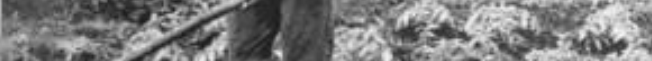
Allocations for $75 / 76-1991 / 92$
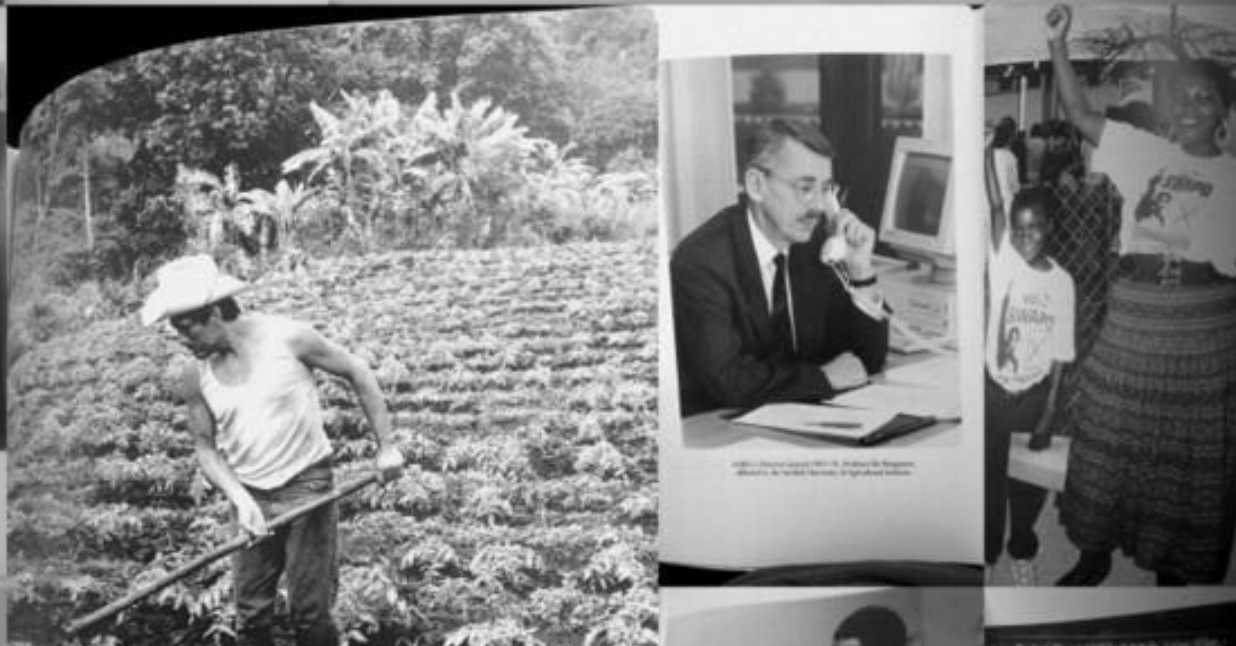

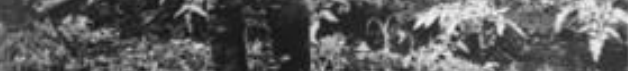

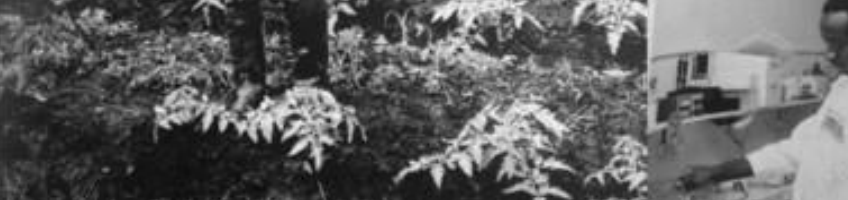
$-7$

4

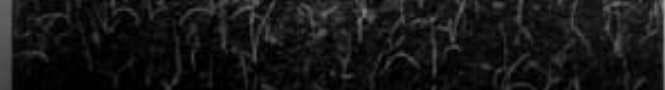




\section{1991-1997: Revival and change}

The main argument for strengthening national capacity is of course that any other alternative would make the South's dependence even greater than it is today. National capacity is the only way to promote independence! There is no shortcut to progress. ${ }^{702}$

- Sarec annual report 1991/1992

Science then is very much looked upon as an instrument for competition and efficient industrial production. I know we all agree when saying that we expect more from science than that! Science has to do with culture. Science has to do with ethics and values. Moreover, we need an actively critical science - which is ready to apply its scientific methods also to the analysis of its own basic assumptions and organization. ${ }^{703}$

- Sarec annual report 1992/1993

You do not exactly get a neat regression analysis, but I maintain that it is ignorant to claim that research aid does not contribute to poverty reduction. ${ }^{704}$

- Former Director Johan Holmberg (1994-1995)

The 1990's was a very intense period of change within both foreign aid and research politics. Development theory started paying more attention to the particular, and grand narratives took a step back at the same time as theories engaging with globalization as a phenomenon gained ground. Aid actors began discussing the protection of "global public goods", calling for agreements to protect vital border-defying resources like water and air. ${ }^{705}$ Critique of foreign aid is a more or less constant phenomenon, but the early to mid1990's was a period when such debate flared up. ${ }^{706}$ A Swedish anthology aimed at sparking debate on aid was published in $1992^{707}$ maintained that the 1980's showed how there is no one solution to development problems. Instead, the authors maintain, problems and solutions are various and sometimes contradictory. Concern was expressed regarding a budding lack of solidarity with low-income countries, pointing at a need for a

\footnotetext{
702 Sarec (1993). Sarec Annual Report 1991/1992.p9

703 Sarec (1994). Sarec Annual Report 1992/1993. p14

704 Transcription (2013). Interview with Johan Holmberg 021413. p7

705 Odén, B. (2006). Biståndets idéhistoria: från Marshallhjälp till millenniemål. Lund, Studentlitteratur. p35

706 There were also cuts in the aid budget, although research aid was not as severely affected.

${ }^{707}$ Uppbrott. Om u-länder, bistånd och solidaritet inför sekelskiftet. En debattantologi (1992) (A debate anthology on the issues of underdeveloped countries, aid and solidarity at the approach of a new century). Some of the authors were: Stefan de Vylder, Björn Hettne, Mats Lundahl, Marianne Laanatza, Bertil Odén, Pierre Frühling, Bo Göransson, Carl Tham, Maria Leissner and Birgitta Wrenfelt
} 
new kind of radicalism and interest in development characterized by pluralism. If this did not materialize, the authors feared a scenario where inequalities within and between countries would continue to widen as rich countries would be focused on their own business:

At the same time as hate and desperation grows in poor countries, a cynicist and rasist ideology breaks out amongst us, it will once again become acceptable to disregard - or see it as normal - that poor people die. ${ }^{708}$

The more optimistic scenario entailed continued positive effects of the spread of democracy, more self-reliant social and economic development coupled with aid based more on solidarity and less on political interests. ${ }^{709}$ Sharing this critical appraisal of past aid was the school of thought post-development which gained ground during this period. An example of the critique from researchers at the time was that people with traditional knowledge and beliefs in low-income countries had been undervalued and treated as "passive receptacles of progress". 710

In terms of research politics, Benner maintains that both the 1990's and the first decade of the 2000's were characterized by the strengthening of the complex and double view of scientific knowledge that emerged in the 1980 's. ${ }^{711}$ Tensions and conflicts regarding the role of research in society, maintained Benner, could be discussed by looking at concepts like ethics, responsibility, innovation, usefulness, quality and excellence. Issues like the dependence on complicated technical systems, challenges of sustainable development and the relation of science to the market and to democracy illustrate how scientific knowledge had become both more crucial as well as seriously questioned. ${ }^{712}$ The direction and usefulness of research was still considered central, but academic freedom was also valued. Melander maintains new systems of distribution of resources involved increased focus on evaluations. ${ }^{713}$ During the 1990 's, these tendencies were budding; systems of innovation as a concept gained some ground, ${ }^{714}$ as did the discussion about Mode I and II. These models as well as systems for controlling and measuring scientific output and quality were to become even more central in the

\footnotetext{
${ }^{708}$ Sandberg, S., Ed. (1992). Uppbrott. Om u-länder, bistånd och solidaritet inför sekelskiftet. En debattantologi, Svensk Volontärsamverkan. p10

709 Ibid. p11

${ }^{710}$ Swantz, M. L. and M. A. Tripp (1996). Development for big fish or for small fish?: A study of contrasts in Tanzania's fishing sector. Decolonising Knowledge from Development to Dialogue. F. Apffel-Marglin and S. A. Marglin, Clarendon Press. p44

${ }^{711}$ Benner, M. (2008). Kunskapsnation i kris. Politik, pengar och makt i svensk forskning, Nya Doxa. p31

712 Ibid. pp31-32 \& 35

713 Melander, F. (2006). Lokal forskningspolitik. Institutionell dynamik och organisatorisk omvandling vid Lunds universitet 1980-2005, Lund University. pp133-134

${ }^{714}$ Eklund, M. (2007). Adoption of the Innovation System Concept in Sweden, Uppsala

University. pp15-16
} 
2000's. ${ }^{715}$ This period presented a unique opportunity for handling global scientific disparities, maintained Elzinga, but national interests or a "Eurocentric bias" continued to dominate the science policy agenda. ${ }^{716}$

A conservative government ruled Sweden in the early 1990's, and was replaced by a social democratic government in 1995. Quickly thereafter, Sarec was fused with Sida along with two other agencies - SwedeCorp and BITS. Sweden also joined the EU in $1995 .{ }^{717}$

This chapter analyzes Sarec's policy development in the 1990s, focusing on how the relationship between research and development portrayed. Following largely the same type of structure as the previous two chapters, I highlight the changes in Sarec's task definition and discuss the development modes of support and priorities. I then ask how research is considered to contribute to development, what kind of development, and how ${ }^{718}$

The discussion about Sarec's task is somewhat revived, a new methods document is produced and Sarec is evaluated once more. The universal and localist discourses both become enforced but at the same time seem to become intertwined; one could call it localist universalism. Many discussions in Sarec's various policy documents and the 20 year review are more polemic than in the previous decade. The local and traditional are brought forth (see post-development) at the same time as the significance of global problems and general knowledge about these increases. Environmental problems and sustainable development come into focus.

\section{The "Sarec model" - evolving modes of support and priorities}

Sarec had grown steadily and went from having 12 staff in the 1970's to over 40 during this decade. Its annual budget increased from 75 to around 450 million crowns between 1975 and $1998 .{ }^{719}$

Sarec had "twin-objectives", one being to assist in building national research capacity in developing countries, and the other to "produce research results on development issues of global relevance". ${ }^{720}$ These objectives do not change significantly during the early and mid-90's, but why research was important as well as the issue of how research aid could contribute to development was discussed quite a bit. A systems-

\footnotetext{
715 Benner, M. (2008). Kunskapsnation i kris. Politik, pengar och makt i svensk forskning, Nya Doxa. pp44-45

716 Elzinga, A. (1995). "Traces of Eurocentrism in Current Representations of Science." VEST 8(4): 85-96.

${ }^{717}$ Something Odén maintains resulted in restrictions on the manoeuvrability of governments in taking political stances that went against other EU countries. Odén, B. (2006). Biståndets idéhistoria: från Marshallhjälp till millenniemål. Lund, Studentlitteratur. p32

718 The material used in this chapter is weighted in a slightly different manner given that Sarec did not produce any annual reports of their own during the years following the fusion with Sida (1995-1997). Sida's annual reports are of a different character and significantly less detailed with regards to research

${ }^{719}$ During the 1990s, the budget first decreased and then increased again considerably in the other half of the decade.

${ }^{720}$ Sarec (1992). Sarec Annual Report 1990/1991. p5
} 
perspective was increasingly underlined, not least in conjunction with discussions about sustainable development. ${ }^{721}$

Up until this time, Sarec's policies and methods had been presented largely in their annual reports. In 1992, however, a methods document was published. Though it was mainly focused on bilateral support as a method, it discussed all Sarec's activities. According to the document's preface, written by former director Bo Bengtsson, it was in part a response to the great interest in their bilateral cooperation method expressed by low-income country research communities as well as other donors. The report's purpose was to describe and analyze how the bilateral method had worked until then, and reflect upon critique and how it could be further improved. ${ }^{722} \mathrm{~A}$ draft of the document was presented at an international conference organized in 1991 by Sarec and the United Nations Centre for Science and Technology (UNCSTD) called International Cooperation in Science and Technology for Development. It was held at the Tällberg foundation in Stockholm.

The report tied back to Sarec's original directives and broke it down into a number of operational aims followed by a definition of research capacity. As mentioned above, there are not significant changes in these formulations. The definition of the capabilities included in research capacity are described a bit differently, perhaps in part reflecting the challenges faced by many universities in Africa during the 1980's:

- to identify problems and define research projects about important development issues;

- to plan and carry out research

- to give advice on and to direct research which cannot be carried out with existing local manpower, and local financial and technical resources;

- to create attractive and functioning research environments;

- to participate in, and benefit from, international research, and

- to disseminate and implement research results 723

\section{Thematic priorities and activities}

Sarec's prioritized thematic areas ${ }^{724}$ were said to structure Sarec's work, and they were 1) health and nutrition, 2) rural development and environment, 3) natural sciences, technology and industrialization, and 4) social sciences and the humanities. ${ }^{725}$ The modes of support (or programme areas) remained unchanged and were used within all the thematic areas. The budget allocations were larger for the first three thematic areas than

\footnotetext{
721 This will be discussed more below, but see for example Annual report 1992/1993, pp8-9 and 1993/1994, pp5-6.

722 Bhagavan, M. R. (1992). The SAREC model: institutional cooperation and the strengthening of national research capacity in developing countries. Stockholm, SAREC. pp5-6

${ }^{723}$ Ibid. p10

${ }^{724}$ Or as they were called during part of the 1990's - "problem-cum-discipline oriented operational sectors"

725 Bhagavan, M. R. (1992). The SAREC model: institutional cooperation and the strengthening of national research capacity in developing countries. Stockholm, SAREC. pp10-11
} 
for social sciences and the humanities. A Sarec report from 1992 maintains that there was a lack of engineers and natural scientists in Africa, something which may partly explain this. ${ }^{726}$ Another reason, according to Sarec, was that the technological and natural sciences were associated with higher costs. A large part of the social science post in the bilateral efforts, furthermore, went to library infrastructure. The support to social science and the humanities within bilateral cooperation was in other words very marginal. This fact is acknowledged by Sarec, and they also stated that there was little demand from the low-income country partners for cooperation in this area and that more substantial support to these subjects was made within the regional programmes. ${ }^{727}$ This could be reflective of the idea that development relevance of science is more easily associated with subjects like medicine, agriculture and other such technologically oriented sciences. At the same time, the basic natural sciences such as physics, math and chemistry were also prioritized and they are neither necessarily technological nor as easily associated with short-term development effects.

There were no major changes in how support was described in this document when it comes to international research organizations, regional research programs and special initiatives, or Swedish development research. I will discuss these methods of support further down, and here focus on the central issues of the methods document - concerning bilateral cooperation.

Africa remained a prioritized continent while collaboration with many Latin American countries ended on account of either having reached the intended objectives, the countries being considered middle-income by then (such as Argentina, Uruguay and Chile) or because of the need to concentrate efforts in face of Swedish aid budget cuts. ${ }^{728}$ After the fusion with Sida, the support of Sarec was also to contribute to the main goals of Swedish foreign aid, which (in addition to poverty reduction) were gender equality, sustainable development and democracy and human rights. ${ }^{729}$

As a way to underscore the importance of support to social sciences and humanities research, the annual reports reflect on globalization and internationalization, analyzing the effects on low-income countries.

Two simultaneous processes are the accelerated global integration and the fragmentation of nation-states. The "Third World" notion is losing its meaning as a coherent concept identifying a group of countries which find themselves in very different situations. It is increasingly difficult even to describe countries as rich or poor. Even in the "First World", social and regional polarization is obvious in the wake of the global integration process. It makes more sense talking about rich and

\footnotetext{
726 Olsson, B. (1992). The Ownership and Cultivation of Knowledge. The rationale for Swedish support to universities in developing countries. Sarec. p15

727 Bhagavan, M. R. (1992). The SAREC model: institutional cooperation and the strengthening of national research capacity in developing countries. Stockholm, SAREC. pp27-28

${ }^{728}$ See for example Sarec (1994). Sarec Annual Report 1992/1993. and Sarec (1995). Sarec

Annual Report 1993/1994. p6

${ }^{729}$ Sida (1997). Sida årsredovisning 1995/1996. p1
} 
poor groups of people, favoured and ill-favoured sectors of society, regions, rural and urban areas. ${ }^{730}$

The quote above is indicative of a different view of the levels of development of low-, middle- and high-income countries compared to earlier. Poverty and other forms of disadvantage was no longer a phenomenon affecting just the so-called Third World - a more complex global interdependence was emerging in the discussion.

The annual reports from the late 1980's and onwards made much more use of graphs and tables to illustrate the numbers and distribution in a more specific way. Sarec's activities are presented in several different ways, divided into thematic areas primarily but also according to modes of support for example. Examples of activities during this decade are presented in the table below. It should be noted that the information concerning the projects and actors involved is less detailed in these reports compared to those of the 1980's.

\begin{tabular}{|c|c|}
\hline Thematic area & Example activities \\
\hline $\begin{array}{l}\text { Health and } \\
\text { nutrition }\end{array}$ & $\begin{array}{l}\text { Budget support to the World Health Organization (WHO). Research on } \\
\text { tropical diseases, human reproduction (infertility, family planning, } \\
\text { contraception for example), diarrhoeal diseases, tuberculosis, acute } \\
\text { respiratory diseases and essential drugs. }{ }^{731} \\
\text { Regional network (Tanzania, Mozambique, Zimbabwe and Zambia) on } \\
\text { reproductive health concerning issues like maternal mortality, family } \\
\text { planning and antenatal and delivery services. This includes some training } \\
\text { collaboration with Swedish universities. }{ }^{732} \\
\text { Bilateral cooperation and joint research program between University of } \\
\text { Gothenburg, Karolinska Institute and King Edward Medical College in } \\
\text { Lahore on child morbidity, growth, breastfeeding patterns. Research } \\
\text { training. } \text {. }^{333}\end{array}$ \\
\hline $\begin{array}{l}\text { Rural development } \\
\text { and environment }\end{array}$ & $\begin{array}{l}\text { Continuation of regional program about deforestation and desertification } \\
\text { aimed at strengthening research capacity and research about preventing } \\
\text { land degradation. Extended to cover agriculture, livestock, biodiversity, } \\
\text { marine and coastal zone research and environmental economics. Support } \\
\text { to different efforts in Africa, Asia and Latin America. }{ }^{734}\end{array}$ \\
\hline
\end{tabular}

\footnotetext{
${ }_{730}$ Sarec (1994). Sarec Annual Report 1992/1993. p53

${ }^{731}$ Sarec (1995). Sarec Annual Report 1993/1994. p13

732 Ibid. p14

${ }^{733}$ Sarec (1994). Sarec Annual Report 1992/1993. p29 and Sarec (1995). Sarec Annual Report 1993/1994. p13

${ }^{734}$ Sarec (1994). Sarec Annual Report 1992/1993. p40
} 


\begin{tabular}{|c|c|}
\hline & $\begin{array}{l}\text { The Pastoral Information Network Project (PINEP). Regional cooperation } \\
\text { in Eastern and Northeastern Africa. Soil and water research. Studying the } \\
\text { "interface between indigenous knowledge and university range } \\
\text { management knowledge".735 } \\
\text { Bilateral cooperation with focus on rural development and environment } \\
\text { varied between countries. Support to Sri Lanka and Vietnam focused on for } \\
\text { example rice research, water buffalo, marine areas and land conservation. } \\
\text { Support to Argentina, Uruguay, Chile, Costa Rica and Nicaragua includes } \\
\text { coastal marine research, forestry research, potato genetics and biological } \\
\text { nitrogen fixation. Support to African countries was more related to capacity } \\
\text { building - infrastructure support and research training. }{ }^{736}\end{array}$ \\
\hline $\begin{array}{l}\text { Natural sciences, } \\
\text { technology and } \\
\text { industrialization }\end{array}$ & $\begin{array}{l}\text { Bilateral cooperation with Asmara University, Eritrea. Support to capacity } \\
\text { building in the basic sciences (biology, chemistry, physics and } \\
\text { mathematics). } .^{737} \\
\text { Support to regional research network AFREPREN (The African Energy } \\
\text { Policy Research Network). Energy researchers and energy policy-makers } \\
\text { from Southern and Eastern Africa cooperate and produce policy studies. }{ }^{738} \\
\text { Swedish development research: hydraulics, food technology, } \\
\text { energy/environment, biotechnology, geographical information systems, } \\
\text { industrial and technology policy and renewable energy. }{ }^{739}\end{array}$ \\
\hline $\begin{array}{l}\text { Social sciences and } \\
\text { the humanities }\end{array}$ & $\begin{array}{l}\text { Support to PASS (The Programme for African Social Science), regional } \\
\text { research networks within for example political science, development } \\
\text { economics, and population-related research. } 100 \text { institutions and } 2000 \\
\text { researchers were involved in total. Conference, methods seminars and joint } \\
\text { publishing. CODESRIA (Development of Economic and Social Research in } \\
\text { Africa) was the council in the network receiving the most support } 740 \\
\text { Gender research. The Sarec board decided to integrate the Women's } \\
\text { Research Programme into the overall policy of Sarec. Gender research was } \\
\text { to be included in bilateral cooperation with African countries for } \\
\text { example. }{ }^{74}\end{array}$ \\
\hline
\end{tabular}

${ }^{735}$ Sarec (1995). Sarec Annual Report 1993/1994. p16

${ }^{736}$ Sarec (1993). Sarec Annual Report 1991/1992. p36

${ }_{737}$ Sarec (1995). Sarec Annual Report 1993/1994. p20

${ }^{738}$ Sarec (1993). Sarec Annual Report 1991/1992, Sarec (1995). Sarec Annual Report

1993/1994. p21

${ }^{739}$ Sarec (1993). Sarec Annual Report 1991/1992. p49

740 Ibid. pp55-56 and Sarec (1995). Sarec Annual Report 1993/1994. p25

${ }^{741}$ Sarec (1995). Sarec Annual Report 1993/1994. p27 


\begin{tabular}{|l|l|}
\hline & $\begin{array}{l}\text { Democracy and human rights. Support to cooperation between South } \\
\text { African universities and Nicaragua on security models. Cooperation } \\
\text { between Mozambique and Zimbabwe on documentation of political and } \\
\text { cultural change. }{ }^{742}\end{array}$ \\
\hline
\end{tabular}

Rural development and environment was an area which increased in importance, and the focus was to be aimed at small-scale, resource poor farmers and long-term environmental aspects in order to contribute to both social and economic development. The local and small-scale are referred to more:

The past approach with an almost exclusive focus on economics - although important - will not suffice. Most research for sustainable development is locationspecific. Thus for instance, there is a need for many more local plant breeding programmes rather than global ones..$^{743}$

The categorization of thematic modes of support changes, and the annual reports are not as detailed every year, so it is not as easy to track how much of the budget is spent on international organizations specifically. If one excludes regional research programmes and special research initiatives, the budget allocation to international research was around $30-35 \%$ during this period. This percentage cannot be compared to previous decades (during which the presentation of activities was slightly different). Sarec continues to criticize the international organizations, but not as much as before. At times, there is strong defence of continuing to provide them with support. Holmberg (director 1994-1995), underlined the importance of CGIAR research (in light of dwindling resources) in a position paper called Future Food Needs, International Agricultural Research and the Role of SAREC. ${ }^{744}$ The paper concerned the question of how to meet global food demands, and Holmberg is critical of the lack of action. He states that more donors should support research capacity building in low-income countries, and that international agricultural research is underestimated:

Sometimes our scientists are their own worst enemies when they say, almost flippantly, that "science is not the problem in raising future food supplies". Decisionmakers, pressed by a host of other problems, will then put that particular problem on the back burner, believing that science can at some later time be called upon to solve the problem if and when it has become more acute. What they conveniently forget, of course, is that, first, science is only part of the solution, second, that science needs to be mobilized and given more resources and, third, that a number of other requirements need to be met as well. And so a dialogue of the deaf continues and

\footnotetext{
742 Ibid. p27

${ }^{743}$ Sarec (1992). Sarec Annual Report 1990/1991. p27

${ }^{744} \mathrm{~A}$ text which was also published in a longer version in the 20 year review Sarec (1995).

Research for Development. Sarec 20 years Kristianstads boktryckeri.
} 
development workers have an increasing sense of frustration that the message is not hitting home.

We believe that the CGIAR has a most essential role to play to allow developing countries meet future food needs. We try to be as active and supportive in CGIAR governance structures and scientific debate as we can, given our limited resources. In summary, we feel that the apparent complacency of political decision makers in the donor community towards future food needs in developing countries is entirely misplaced. There is also the added argument that our politicians underestimate our dependency on agriculture in developing countries and therefore the mutual interest rich and poor countries alike have in international agricultural research. ${ }^{745}$

The mission of the paper is to protest about the complacency with which they consider both researchers and politicians (including other donors) to be handling the threat of food security in the world. The views and arguments put forth by both political principals and scientific agents are incomplete, maintains Holmberg, science and politics are both needed in these challenges. Furthermore, while this reflects a more positive view of the role of international organizations, it is also clear that this is partly conditioned by the ability of the aid actor to be present and active.

Given that universities were the main actors in bilateral support, and one of the major tasks of universities is usually to provide higher education, it is interesting to analyze how it was handled in Sarec's policy. Higher education is raised and discussed more often this decade than during the first two decades. Research capacity is seen to more or less directly improve the quality of higher education at the university. ${ }^{746}$ It was, however, not the task of Sarec to get directly involved with education. At one point it was suggested that Sida should support higher education and complement Sarec's activities, but this did not materialize. ${ }^{747}$ In 1994 , a liberal party politician (Ylva Annerstedt, fp) proposed to the parliament that Sarec's mandate should be expanded and include higher education, ${ }^{748}$ but this proposal was rejected by the foreign affairs committee (utrikesutskottet) on the grounds that they did not see any reason to change the direction of Sarec's activities. ${ }^{749}$ While higher education was envisioned as being benefited by research capacity, the political principals in question wanted Sarec's focus to remain on research.

\footnotetext{
${ }^{745}$ Holmberg, J. (1992). Future Food Needs, International Agricultural Research and the Role of SAREC, Sarec. p2

746 See for example Sarec (1994). Sarec Annual Report 1992/1993. p5

747 Transcription (2009). Interview with Berit Olsson 092509. p6 It was also discussed in

Olsson's paper from 1992

748 (1994). Motion 1993/94:U214, Biståndssamverkan rörande högre utbildning.

749 (1994). Utrikesutskottet betänkande 1993/94:UU15 Internationellt utvecklingssamarbete.
} 


\section{Bilateral cooperation in focus}

Research capacity continues to be constructed as something that will increase independence, and bilateral cooperation was the main method through which to achieve this. Former director Wijkman reflects upon the role of research in development:

...If you do not [...] build something that helps low-income countries being able to develop on their own, then these countries become dependent on aid forever. I see research capacity building as one important piece of the puzzle that can help strengthen the productive forces. ${ }^{750}$

Bilateral cooperation had been a fast-growing mode of support in the late 1980's and early 1990's as a result of previously expressed ambitions in Sarec policies and the recommendations in the 10 year evaluation. It had gone from 40 to 216 projects between 1982 and 1992.751 Sarec published a report in 1992 (it can also be called a methods document of sorts) that described "the Sarec model" of bilateral institutional cooperation. I will discuss this methods document and some of the issues associated with the model according to evaluators.

The model entailed two kinds of cooperation - one that was "capacityemphasizing" and one that was "result-emphasizing" - though they were considered as overlapping in several respects. ${ }^{752}$ The cooperation with countries that already had relatively strong research capacity like Argentina and India focused on producing research results of relevance to the country in question, but also to other middle- and lowincome countries. The cooperation had to be within areas where Sweden had "advanced expertise" and the quality needed to be of high international standard. ${ }^{753}$ Costs covered included travel and essential scientific equipment. No local costs were covered in the lowincome countries, but some part-time salary support was provided to Swedish researchers. ${ }^{754}$

Cooperation with countries that had relatively weak research capacity focused primarily on getting a critical mass of researchers and on supporting the environment where they worked, basically. Bilateral cooperation consisted of research training, certain collaborative research projects and support to scientific equipment and libraries. Costs covered were research training, scientific equipment (including procurement etc.), library support, travel and stay costs, minor equipment and some Swedish salaries. It did not necessarily have to involve cooperation with Swedish institutions (non-Swedish actors were allowed) but it was deemed preferable since it was more cost-effective essentially. ${ }^{755}$

\footnotetext{
750 Transcription (2010). Interview with Anders Wijkman 042910. p6

${ }^{751}$ Bhagavan, M. R. (1992). The SAREC model: institutional cooperation and the strengthening of national research capacity in developing countries. Stockholm, SAREC. p45

752 Ibid. pp12, 26 \& 44

753 Ibid. pp12 \& 19

754 Ibid. p21

755 Ibid. pp17-19
} 
Different types of research training were integrated with bilateral cooperation. The so-called "sandwich model" and "building up the indigenous base" were used in cooperation with countries that had weaker research capacity while short-term advanced courses were organized within the results-oriented cooperation. ${ }^{756}$ The first two were focused on Masters and PhD level research training, one which included stays in Sweden and one which was mean to support development of local research training capacity. In the sandwich model, students travelled to Sweden for some periods of their research, whereas in the indigenous model, Swedish researchers visited the low-income country to teach and supervise certain periods. ${ }^{757}$

Though the "content and form" of the bilateral cooperation was said to be determined by the low-income country in question, the availability of Swedish expertise was considered crucial, and a long-term commitment was important.758 The policy constructs the role of "advanced" foreign institutions as crucial for the low-income country institutions in the process of becoming independent:

To become eventually self-sustaining, the capacity-building process must be firmly rooted in the developing country institutions themselves, with adequate resources put at their disposal, and with the reassurance that their links to scientifically advanced institutions abroad will be longstanding and durable to ensure the consolidation and the continuity of the learning process. ${ }^{759}$

The policy envisions the low-income country institutions as needing help in the learning process, to eventually become sustainable. A certain level of dependence in the short term was deemed necessary for independence in the long-run. The aid actor is described as a catalyst in this process that could "help initiate and accelerate the process by providing appropriate, if modest, inputs at critical junctures". ${ }^{760}$

Former director Rolf Carlman (1995-1999) maintains that bilateral cooperation and its institutional focus was a successful model, but that Sarec sometimes had to mediate in order to ensure the fulfilment of this mutual interest:

It was an efficient way to attempt to stop the brain drain syndrome [...] Of course one had to be careful so the relationship did not become too asymmetrical [...] It became our task to ensure that it was not only serving the Swedish institutions' interest. ${ }^{761}$

Sarec's annual report from 1992 states that the standards were highly set and not entirely representative of reality, but a goal they wanted to strive for. They clearly uphold equality

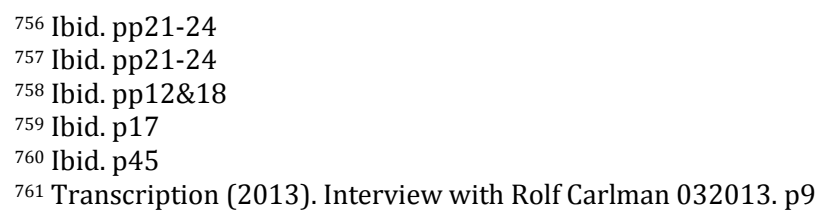


between the collaborating partners as central, and underline the importance of mutual interest. Sarec describes the ideal bilateral cooperation:

The research work and the research training undertaken are of strong mutual interest and designed to benefit both sides. Neither of the research groups is miniscule in size, but has some substantiality in numbers. Genuinely joint efforts are combined with true complementarity in project tasks. The two groups meet regularly to review ongoing work, plan future activities and jointly draft renewal applications. Both sides have full information on the budget allocations to each side and how funds are being spent. Scientific papers are written jointly, with the names from both sides appearing on the published articles. A key factor in determining the success of a project is whether the project leaders on both sides are senior scientists occupying central positions in their respective institutions. ${ }^{762}$

The period of Swedish cooperation with Cuba was one example Carlman raised as very fruitful and equal. Swedish researchers had certain methodological expertise for instance while the Cuban researchers had unique longitudinal health-data on their population and in some cases very good laboratories - the mutual interest was strong and efforts were made to keep the cooperation going after the formal aid was stopped. ${ }^{763}$

\section{Critical evaluation}

Before the publishing of some of the reports referred to above, Sarec commissioned an external review of bilateral cooperation which was presented in 1990. This evaluation was subsequently discussed at some length in the 1992 methods document about the Sarec model. The review was conducted by external consultants Carl Widstrand (professor in anthropology and archaeology) and Jan Valdelin (associate professor in economics), covering cooperation projects with 13 countries and including over 100 interviews. Widstrand and Valdelin concluded that low-income country researchers and other contacts seemed satisfied with the support in general. Furthermore, Sarec's focus on supporting research made them unique among state development organizations with its broad approach, long-term perspectives and an openness to collaborate with third country actors on certain aspects like research training. ${ }^{764}$ The evaluators maintained that while Sarec support clearly was having many beneficial effects both abroad and in Sweden, the bilateral model had several problems in its practical implementation. ${ }^{765}$ Some of these problems, including Sarec's responses, will be discussed below.

Several of these problems, according to the evaluators, were partly due to the fact that Sarec's administrative capacity had not matched the rapid increase in bilateral projects:

\footnotetext{
762 Bhagavan, M. R. (1992). The SAREC model: institutional cooperation and the strengthening of national research capacity in developing countries. Stockholm, SAREC. pp5-6

763 Transcription (2013). Interview with Rolf Carlman 032013. p9

${ }^{764}$ Widstrand, C. and J. Valdelin (1990). An Evaluation of the Bilateral Institutional Research Cooperation supported by Sarec. pp9 \& 17

765 Ibid. pp5
} 
It is quite obvious from the rapid accumulation over the last few years of collaboration agreements that SAREC has not stopped and looked at what they are doing. We believe that SAREC has taken on too much in this field without regard to its administrative capacity and without streamlining agreements, contract and the administrative routines for the running of the projects. ${ }^{766}$

They maintained that Sarec staff seemed stressed and overworked, something which hampered adequate handling of various tasks and prevented the kind of "feedback loops" required for an organization to learn from its mistakes. ${ }^{767}$

One issue Widstrand and Valdelin raised was that of setting priorities for research. They maintained that there was not enough development-relevant research to choose from at Swedish institutions, and that the priorities in practice were set by the Swedish institutions, not the low-income countries. Furthermore, they were of the opinion that the Swedish researchers in general had too little experience with low-income countries:

Many university institutions lack the least experience of working in developing countries. We observe that some DC institutions have, during their planning trips, met the wrong kind of researchers or the unsuitable university institution to collaborate with, One common problem is the involvement of self-promoting individuals, more interested in a diploma than in real knowledge and scientific pursuits. ${ }^{768}$

Sarec responded to this in their methods document, maintaining that because the Swedish institutions had more resources and capacity in general, the low-income country partners often became "junior" in comparison:

Under these conditions, it is almost inevitable that the Swedish side should find itself slipping into the role of deciding what, how and when things should be done in the project, with the other side having to defer willy nilly to the "superior experience and wisdom" of the Swedish side. ${ }^{769}$

Informal interventions by Sarec research officers were required, and sometimes formal evaluations, in order to balance this asymmetry. Regarding the priorities, Sarec's response was that though an important underlying principle has been that the priorities of low-income countries should determine scientific content, it had proven difficult to live up to.

\footnotetext{
766 Ibid. p29

767 Ibid. p29

768 Ibid. p31

${ }^{769}$ Bhagavan, M. R. (1992). The SAREC model: institutional cooperation and the strengthening of national research capacity in developing countries. Stockholm, SAREC. p42
} 
There are intense, and often bitter, rivalries between individuals and groups, who are competing for limited national and foreign resources. This is the case even in those countries with national research councils with official mandate to set priorities and coordinate research on a national basis. ${ }^{770}$

Instead, Sarec maintained, they studied the country's research landscape, consulted with research leaders and leading government officials for example, in order to decide how to best establish cooperation. A number of research areas and institutions are identified as potential cooperating partners, and if they in turn were interested - Swedish institutions were contacted. Sarec stated that they preferred this way of establishing partnerships since initiatives coming from Swedish researchers tended to emphasize their own priorities. ${ }^{771}$

The fact that part-time salaries were provided to Swedish researchers but not to low-income country researchers was considered a dilemma by the evaluators as well. Low-income country researchers often had to take on other jobs in order to be able to keep doing research, creating great inequality. The solution suggested is that Sarec start paying part of their salaries as well. ${ }^{772}$

Widstrand and Valdelin maintain that budget transparency should increase and that more economic costs should be taken by the Swedish universities as part of their internationalization efforts. The price for Swedish capacity was too high according to them, and they suggested setting a limit to how much money Swedish institutions could get (a maximum of $25 \%$ of the total budget). In the case of cooperation with middle income countries, Swedish universities should not get any money at all. ${ }^{773}$

In this perspective it is also a paradox that the "capacity building" type of support (where no one seems to expect any real output of research in many years to come) is being given to exactly those countries where salary levels in themselves are an obstacle to any "capacity" in research. To want to support a build-up of "long-term capacity" and at the same time only support training abroad and the imports of equipment, is really just to dodge the issue. ${ }^{774}$

The evaluators were of the opinion that the salaries issue was a serious one, but Sarec's response was that it was deemed justifiable to give Swedish researchers part-time salaries because their costs were higher than those in the low-income countries (yet still cheaper than international consultants), and it was a part of Sweden's national priority.

\footnotetext{
770 Ibid. p40

${ }^{771}$ Ibid. pp 40-41

772 Widstrand, C. and J. Valdelin (1990). An Evaluation of the Bilateral Institutional Research Cooperation supported by Sarec. p43

773 Ibid. pp19, 21-22. 28, 33 \& 43

774 Ibid. p33
} 
Furthermore, they argue, the Swedish researchers' time benefits the low-income country actors since much of the money is spent on research training. ${ }^{775}$

\begin{abstract}
It seems to us that the problem really is not one of Swedish costs, but of the fact that in some of the developing countries the salaries of local researchers and their support staff is so low that they simply cannot subsist on them. [...] If research is really a priority for a developing country, then that commitment should be shown, not least, through adequate remuneration of its nationals engaged in research work.776
\end{abstract}

A boundary is drawn here by Sarec with respect to what they believe to be the responsibility and priority of the low-income country. The same argument (expecting certain things to be prioritized locally/nationally in the low-income countries), however, could theoretically be used to question Sarec support to building libraries or labs as well. In other words, the different perspectives held by the evaluators and Sarec show that where the boundary is drawn regarding what is "ok" to finance is clearly a matter of negotiation. A few years later, a slightly different view is expressed by Sarec in a conference paper ${ }^{777}$ by Ann-Marie Fallenius, who writes that "one problem with the Sarec model is the relatively high cost for the participation of the Swedish institutions." 778 She suggests that the cost-effectiveness of institutional cooperation and research training is an area where comparative studies would be interesting, indicating a more flexible view of their own operations as an aid actor.

Another point of critique from Widstrand and Valdelin was the fact that Sarec had inconsistent procedures for sending money and for accounting and procurement of services and equipment as well. There were too many ad hoc solutions. ${ }^{779}$ In this context, the relationship with Sida was raised as problem since Sida could reasonably have been of assistance with procurement for example, having more administrative capacity. "Sida is Sida and Sarec is Sarec and the twain shall never meet" they write, and proceed to account for the seemingly non-existent relationship between the two agencies.

There is no central purchasing agency in SAREC. We have asked why researchers have not used SIDA's purchasing office, but have got some very interesting, but unprintable, replies. It would seem that SAREC purchases were never given any priority - maybe because of their rather limited size compared to the buying of locomotives or a harbour for Dar es Salaam. The services of the local SIDA office, the DCO, also took an intolerably long time. ${ }^{780}$

\footnotetext{
775 Bhagavan, M. R. (1992). The SAREC model: institutional cooperation and the strengthening of national research capacity in developing countries. Stockholm, SAREC. p36 \& 49

776 Ibid. pp36-37

777 On the topic of international scientific cooperation

778 Fallenius, A.-M. (1996). Research Capacity Building in Developing Countries. International Scientific Cooperation. Paris. p102

779 Widstrand, C. and J. Valdelin (1990). An Evaluation of the Bilateral Institutional Research Cooperation supported by Sarec. pp25-27

${ }^{780}$ Ibid. p27
} 
They suggest that Sarec find ways to use the embassies and local Sida offices to make cooperation more effective. ${ }^{781}$

Another problem with the bilateral model according to the evaluators was the lack of clarity and consistency in terms of how much time a collaboration was to go on. How was the length to be primarily determined and measured (the project objectives, the situation in the country or a set number of years)? And in relation to this, when was the collaboration to be stopped? They also point out that many collaborations basically consist of research training, and question whether Sarec should not specify standards to create a better balance between research and training, and improve the analysis and reporting of project output. ${ }^{782}$

The evaluators' view of Sarec's support was that it needed to be more clearly defined in order to be effective. It is a call for both more explicit and pragmatic support (including a clear exit-strategy) and for less steering in the low-income country context.

\section{0 years of existence; taking stock and "returning" to Sida}

Sarec spent its first four years as an advisory body tied to Sida, and in 1995 they were fused together once more, along with SwedeCorp and BITS (two other small aid agencies). Some of the reasons for the fusion, as presented in government bills, were that the Swedish aid administration landscape had become too diverse and risked appearing confusing to collaborating organizations and countries (the number of actors, sectors and countries were too many). Furthermore, changes in the world (concerning environment, wars and migration for example) were said to place new demands on Swedish aid, not least because Sweden was entering into the European Union. ${ }^{783}$

Though a potential fusion had been discussed in parliament, there had been no analysis carried out about the pros and cons, according to Wijkman (who was director until the merger). The decision came all of a sudden - less than one month after the new government took over - and it was more a matter of party politics than any well-thoughtthrough organizational change. ${ }^{784}$ Apart from the relatively brief information in the government bills referred to above, I have not found any investigation regarding the matter, but several other former directors express similar thoughts in relation to why the fusion happened so suddenly. Rolf Carlman (Director 1995-1999) for example, maintained that there was a sort of "investigation fatigue":

It would have been nearly impossible to start a new investigation because what was happening was that they [the government] caused a long period of uncertainty by initiating one investigation after another. [...] When the social democrats returned

\footnotetext{
781 Ibid. pp30-31

782 Ibid. pp16-17 \& 23

783 (1995). Regeringens proposition 1994/95:100 - Förslag till statsbudget för budgetåret 1995/1996 and (1993). Regeringens proposition 1992/93:244 - Om styrnings- och samarbetsformer i biståndet.

784 Transcription (2010). Interview with Anders Wijkman 042910. p5
} 
they turned things around by deciding on a merger and charging the appointed Director General, Bo Göransson with the task of proposing how it should be done.. [...] Of course there were good reasons for a merger... you have different aid instruments and if you put them together there is a bigger chance you will use them effectively. ${ }^{785}$

The former directors who were in some way involved maintain that they worked to ensure Sarec's organizational intactness and relative independence in the process of merging with Sida. The importance of management and their understanding of research aid is also raised. Bo Göransson (director general of Sida during the merger), for instance, was described as a person who understood the "special case" of research and supported a kind of continued independence for Sarec within Sida. ${ }^{786}$ This is not to say that there were no problems. The fact that Sarec was allowed to enter Sida without any major reorganization shows that the boundary between research aid and other aid - or science and politics as it was often constructed - was successfully maintained. This boundary, however, was contested, as will be discussed in coming sections of this chapter as well as in the next chapter.

In the same year that Sarec fused with Sida, Sarec published a 20 year review (Research for Development. Sarec 20 years), an anthology with the purpose of discussing various aspects of research aid and outline which areas should be in focus in the future. The book starts with an introduction by Wijkman, and is followed by 14 articles by different researchers on a wide range of topics. ${ }^{787}$ The introduction paints a relatively negative picture of the preconditions for development in general with diminishing aid budgets internationally at the same time as high ambitions and goals had been set at UN conferences. ${ }^{788}$ There are several references to big changes occurring, unprecedented technological development (not least biotechnology and ICT), deregulation of financial markets, the diminishing role of nation states and problems of unemployment. The risk of social and environmental dumping is also mentioned. ${ }^{789}$ These changes were said to be "superseding" the old Marxist tension between labour and capital, the tension instead becoming about who has access to new knowledge and who does not. ${ }^{790}$ The fears altogether expressed reflect a very bleak sociotechnical imaginary.

Against this backdrop, Wijkman states, it is ironic that an organization such as Sarec ceases to exist as an independent agency. He proceeds to say that the publication

\footnotetext{
785 Transcription (2013). Interview with Rolf Carlman 032013. p3

${ }^{786}$ See for example Carlman, p4 and Holmberg p4

787 Gudrun Dahl, Birgitta Odén, Mats Kihlberg, Sverker Sörlin, Stephen Karekezi, Erik W.

Thulstrup, Christine von Weizsäcker, Malur R. Bhagavan, Jan Holmgren, Ann-Mari Svennerholm, Jan S. Nilsson, Johan Holmberg, Madeleine von Heland, Ricardo Petrella, Martin Khor and Arne Jernelöv

${ }^{788}$ Sarec (1995). Research for Development. Sarec 20 years Kristianstads boktryckeri. pp7-8

789 Ibid. pp7\&9

790 Ibid. p7
} 
is not intended to be Sarec's "swan song", however, and recommends that Sida build on Sarec's experience and strengthen long-term capacity building efforts. ${ }^{791}$

The introduction also directs critique against disciplinary sciences, similar to the critique delivered in the annual reports in the first half of the decade. The centrality of universities is underlined, not just because they conduct research, but for higher education and democratic development. Wijkman asks for more engagement from the scientific community, and for a wider concept of development that includes social and environmental factors much more actively. ${ }^{792}$

Some of the authors' contributions and conclusions will be discussed here since the review contains interesting discussions about factors that affected the view of research aid at the time. One of the chapters is written by history and anthropology professors Gudrun Dahl and Birgitta Odén ${ }^{793}$ on the ideas of knowledge and how it is valued. Sweden has always had strong faith in research and development, they state, something which had increased with new ICTs: "The utopias of tomorrow are readily constructed in terms of the new knowledge society. Power over knowledge is coming to be seen more and more as a precondition of prosperity."794 They ask what things can be considered universal and question when values become imposed in a manner which overrides local interpretations, definitions and priorities. They conclude among other things, that beyond "basic economic security", any ideas about what improvement is - are culturally specific. ${ }^{795}$ Supporting research is important, but local knowledges have to be respected: "To put it more brutally, one must be able both to assert the value of the exclusiveness of one's own education and capable of respectfully listening to expertise of the illiterate".796 Odén's and Dahl's text illustrates, among other things, that the knowledge society discourse was gaining ground as a major frame of reference.

Environmental history professor Sverker Sörlin writes about research policy and how it was at the time still formulated in terms of national interest, making the solution of transnational development problems unattractive and - a "dubious" investment. He claims that this is unfortunate since global research is compatible with the national interest of competitive capacity and welfare in Sweden. The reason universities failed at this task in the 1970's, Sörlin maintains, was that the motive of solidarity did not suffice, they needed self-interest as a guide as well. ${ }^{797} \mathrm{He}$ is critical of the old development theories - from both sides of the spectrum (using Walt Rostow's and George Basalla's work from the 1950's and 60's as examples ${ }^{798}$ ) - maintaining that neither of them recognized the fact that there were scientific centres in the "South" even back then, just

\footnotetext{
791 Ibid. p8

792 Ibid. pp11-14

${ }^{793}$ The same chapter that Åke Thörn referred to in the quote at the beginning of chapter four in this book (previous research)

${ }^{794}$ Sarec (1995). Research for Development. Sarec 20 years Kristianstads boktryckeri. p24

${ }^{795}$ Ibid. pp25-26

796 Ibid. p36

${ }^{797}$ Ibid. pp49-61

798 Rostows work on stage theories of growth and Basalla's work on how unequal scientific relations were established through colonialism
} 
as there was "peripheries" in the North. Regardless of this, he states, there are inequalities which can be abated by research, and donor countries should not "evade responsibility by remarking that others too have short-term, selfish interests."799 In other words, Sweden should cooperate with low-income countries on development problems regardless of whether other, comparable countries are doing so. The transnationalization of science and technology taking place, maintains Sörlin, should not be based on geographic bias and only strengthen "North-North" relations. Sweden should engage in global sustainable development, researchers and students should be more present in "Third World Countries". If solidarity and scientific interest are not enough, industrial policies could be involved, states Sörlin. He suggests that the Swedish research councils ought to be able to include transnational scientific interests in their definitions of relevant research, so as to enable more cooperation with low-income countries. ${ }^{800}$

Another issue raised in the 20 year review include the problems and positive aspects of capacity building as a concept and method. Industrial engineer and environment specialist Stephen Karekezi maintains that since capacity building became a buzzword amongst aid actors, short-term perspectives had begun to take over. He maintains among other things that short-term capacity building efforts are much more expensive and do not contribute to autonomous development as much as long-term efforts do. ${ }^{801}$

There are several other topics covered in this review, such as the role of new technologies, support to basic sciences, aspects of international research, challenges of a growing population, environmental development scenarios and the effects of global economic liberalization. Suffice it to say, however, that the review raises both challenges and possibilities for research aid from a variety of different perspectives; not least the demands and possibilities of the knowledge society and the growing challenge of sustainable development.

\section{One research university per country}

Economic crises and other issues meant that resources for African universities were stretched thin and their capacity was seriously reduced by the early 1990's. Economic recessions together with very high and increasing demand for higher education and lack of research and management capacity made the situation at many African universities very difficult according to a report called The Ownership and Cultivation of Knowledge (1992) by Berit Olsson. ${ }^{802}$ An important point of departure, according to the report, was:

...the understanding that indigenous competence and capacity for analyses and research is of fundamental importance for the national development and

\footnotetext{
${ }^{799}$ Sarec (1995). Research for Development. Sarec 20 years Kristianstads boktryckeri. p51-52

${ }^{800}$ Ibid. pp54\&57-62

801 Ibid. p76

802 Olsson was working at Sarec, but not as director at the time. This report was later $(1995 / 1996)$ attached as part of a response from Sida and Sarec to the government about how to best abate the negative development in African universities.
} 
independence, and that the universities have an important role to play in this context. ${ }^{803}$

Excessive financial and intellectual dependence on high-income countries was common, and the importance of research capacity for the quality of teaching and the democratic function of the university was underlined. Without well-functioning universities, these important roles and tasks would not be fulfilled. ${ }^{804}$ Sarec support had been more focused on departments and/or individual researchers, whereas the suggestion was to look at the entire institution and support management levels and infrastructure as well as research training and certain department research. The aim was ultimately to assist the universities to retain and recruit qualified staff and be able to independently manage their affairs. ${ }^{805}$

The conference paper by Fallenius in 1996 (discussed earlier in the chapter) underscored that a central precondition for institutional support was that the country governments were interested in university development. Furthermore, quality was more important than quantity and it was not advisable for donors to spread their resources too thinly. Establishing new universities or colleges was something Sarec definitely advised against. ${ }^{806}$ This is reminiscent of the critique Sarec received in the 10-year evaluation, concerning the building of research councils from scratch. Creating structures from scratch as foreign actors mirrors a highly universalist approach against which Sarec in this case positions itself, instead recommending building on what is already there. Fallenius also called for increased donor coordination to reduce inefficiency and criticized other donors for being too controlling in relation to the low-income countries in terms of priorities and project management:

To take one example: in 1990/91, some 20 different donors provided around 10 million dollars to support some 150 agricultural research projects in Tanzania. The many consequences of these different projects include duplication, lack of overview and coordination and - for Tanzanian scientists - a general sense of being run by donors rather than by national plans. ${ }^{807}$

These problems were also discussed in Olsson's report. Capacity building became more common as a method in foreign aid around the world in the 1990's, but donor efforts pertaining to research were often short-term and heavily conditioned in terms of direction. Research training and scholarships abroad were common for example. ${ }^{808}$

803 Olsson, B. (1992). The Ownership and Cultivation of Knowledge. The rationale for Swedish support to universities in developing countries. Sarec. p6

804 Ibid. pp2,3\&7

805 Ibid. pp1-3

${ }^{806}$ Fallenius, A.-M. (1996). Research Capacity Building in Developing Countries. International Scientific Cooperation. Paris. pp102-104

807 Ibid. p104

808 Olsson, B. (1992). The Ownership and Cultivation of Knowledge. The rationale for Swedish support to universities in developing countries. Sarec. pp8\&11 
...the academics in the universities and researchers at the research institutes in developing countries may feel like perpetual trainees who never have the chance to take the initiative in research or to assume responsibility. 809

The focus on short-term projects implied among other things that the researchers were not as able to develop independent academic traditions. The fact that donors managed much of the projects and support (in part since the capacity to do so was low at the lowincome country university) also contributed to continued dependence and hampered independent capacity to manage university affairs, maintained Olsson.810 Eduardo Mondlane University (UEM) in Mozambique, for example, could only "control" one third of its budget and therefore invited all the involved donors to discuss its situation - as an attempt to increase coordination and efficiency. The fact that donors had certain mandates and preferences could lead to "prosperous, sometimes over-resourced, university departments existing alongside languishing departments which have virtually nothing." 811 This could indicate that donors had certain predetermined priorities in common that they wanted to support, and the report states that donors should not superimpose external ideas and instead align themselves more actively with the universities' own plans and priorities. ${ }^{812}$ This would presumably avoid the kind of extreme inequality between departments described above.

Well-educated people were needed "to fill key posts, partly to replace external advisers and consultants".813 In order to achieve this, Olsson suggested supporting entire universities, one research university per collaborating country. Institutional capacity would be supported through assistance in improving planning and administration on management levels, including issues like procurement and maintenance. "Core functions" were also to receive support; libraries, certain equipment and funds for staff development and research exchange and regional collaboration. University-based postgraduate training was to be encouraged and supported (in addition to, and sometimes instead of, sandwich programs). Experience with increasingly demandled projects had been positive according to Olsson and should be expanded. ${ }^{814}$ Increased cooperation between Sida and Sarec was also suggested, efforts were to be coordinated and could sometimes overlap, but in general Sarec was to have overall responsibility for

\footnotetext{
${ }^{809}$ Ibid. p15

${ }^{810}$ Ibid. pp11\&14

811 Ibid.pp23-24

812 Ibid. pp3-4 \& 24-25

813 Ibid. p7. An interesting reference in the report is when Olsson mentions that over 100,000 foreign experts were working in Africa at the time (according to reports by the World Bank) ${ }^{814}$ For example, where low-income country researchers themselves were required to contact Swedish universities to arrange and administer agreements for training. Regional cooperation programs based on already existing research projects (not externally defined), support to "domestic" postgraduate training programs and general budgetary support to universities. Ibid. pp32\&36
} 
support to research and Sida would be responsible for support to undergraduate education. ${ }^{815}$

There is no one model, states Olsson, but maintains that research and higher education are two mutually dependent functions that are needed in all countries:

This is a delicate task and there is no ready model to recommend. In general, however, certain choices must be made between quantity and quality. We assume in this discussion that it is essential for every nation ${ }^{816}$ to have at least one welldeveloped university ${ }^{817}$ with capacity for research and higher education in central areas. ${ }^{818}$

Olsson's report can be seen as a strong expression of the localist discourse, although there are also universalist assumptions at play, something which is partly illustrated by the quote above. The report is clearly anti-colonialist and reflexive of systemic complexity and specific country contexts at the same time as it advocates a relatively specific set of ingredients to create the research university.

\section{Framing horizontal research as key to sustainable development}

During the early 1990's, the annual reports once again had long essay-like introductions where basic policy questions are discussed in more detail. ${ }^{819}$ This time, a considerable amount of criticism is directed at the organization of science in general and the environmental issues are used as an example to justify the need for more interdisciplinary research. ${ }^{820}$ Scientific disciplines as a way to conduct research are both lauded and found inadequate as a method of contributing to development, and not least sustainable development. Reference is also made to a need for a change of value systems, where "we" in the high income countries must analyze our "culture of instant gratification" and begin to think more about future generations. ${ }^{821}$ The director at the time, Anders Wijkman, maintained that one of the biggest changes during his time there was the increased focus on environmental issues and sustainable development:

If I succeeded at anything it was to get sustainable development on the agenda as a research priority, and we started agricultural projects, energy projects, marine

\footnotetext{
815 Ibid. p42

816 Footnote in the quote: "with the possible exception of very small nations"

817 Footnote in the quote: "One university in this context means one university system. In Tanzania, for example, the Faculty of Agriculture is organized as an independent university. In Mozambique the Faculty of Education is at the independent teacher training college. 818 Olsson, B. (1992). The Ownership and Cultivation of Knowledge. The rationale for Swedish support to universities in developing countries. Sarec. p20

819 This sometimes seems to be when a new director is making their mark, but of course the character of the annual reports is also affected by many external and internal things that I cannot account for here.

${ }^{820}$ See for example Sarec (1994). Sarec Annual Report 1992/1993. pp9-10 and Sarec (1995).

Sarec Annual Report 1993/1994. p3

${ }^{821}$ Sarec (1995). Sarec Annual Report 1993/1994. p3
} 
sciences, environmental and ecological economics. But I had to fight hard for it in the Board because these were new issues. ${ }^{822}$

Wijkman's account illustrates what is also clear in the annual reports - a change in priorities during the early 1990's. The UN Conference on Environment and Development (UNCED) in Rio de Janeiro 1992 is portrayed as a challenge for science.823 Sarec maintained that UNCED changed the focus of development. In relation to the problem of deforestation for example, an annual report stated:

During and after the Conference the discussion has broadened. Focus now is more and more on land-use and not only on forests. Thus, the perspectives of local people come much more into the picture... it is essential to recognize the needs of local people, to tap their knowledge and to involve them in the development of sustainable management systems. ${ }^{824}$

The annual report from 1992/1993 maintains that in addition to the moral imperative there is also the issue of global security. Without a raised standard of living, the pressure on the global ecosystem and conflicts in and between nations will be increased, and mass migration will occur. ${ }^{825}$ Science is portrayed as a potential part of the solution to this development, more specifically science with a systems-perspective, traditional disciplines together with cross-disciplinary or horizontal research efforts. ${ }^{826}$ UNCED is criticized for not underlining the limits to growth enough, and economics is taken as an example of how science needs to be changed to contribute to sustainable development. ${ }^{827}$ Sarec maintains that the "disease of verticalization" - or a high degree of scientific specialization - is partly to blame for the environmental crisis:

Technocrats have a tendency to look at Nature as infinitely big - both as a source for raw materials but also as a sink for pollutions and waste materials. Hence economic models presently used give little incentives for conservation or for curbing pollution. To promote sustainable development a more integrated approach to environment and economics is needed. ${ }^{828}$

At the core of the problems just referred to seems to be the very organization of science. This is somewhat of a paradox. The progress of science during the last few centuries rests largely on the ability of the researcher to limit his or her scope when

\footnotetext{
822 Transcription (2010). Interview with Anders Wijkman 042910. P1

${ }^{823}$ See Sarec Annual Report 1991/1992, Sarec, 1993 and Sarec Annual Report 1992/1993, Sarec, 1994

${ }^{824}$ Sarec (1993). Sarec Annual Report 1991/1992. p10

825 See for example Sarec (1994). Sarec Annual Report 1992/1993. p5 and Sarec (1995). Sarec

Annual Report 1993/1994. p3

${ }^{826}$ See for example Sarec (1992). Sarec Annual Report 1990/1991. pp27-28 and Sarec (1994).

Sarec Annual Report 1992/1993. pp5-6

827 See for example Sarec (1995). Sarec Annual Report 1993/1994. p4

${ }^{828}$ Sarec (1993). Sarec Annual Report 1991/1992. p13
} 
formulating problems. Specialization has been very successful. However, many of the problems facing mankind are of a nature where a systems-view is required rather than a view focusing on the parts. ${ }^{829}$

As the decade progressed, the critique of the organization science seems to subside. As I have pointed out, the Sarec annual reports ceased temporarily when Sarec joined Sida, and a new director was appointed at the same time. The Sida reports were not nearly as extensive in their coverage of Sarec's activities. From my interviews with former directors, it seems that what characterized those years was mainly getting acquainted in the new organization and defending the "special case" of research.

\section{Localist universalism? The branches grow closer}

There is no clear dominating discourse in the 1990's; there are strong elements of both the localist and universalist discourses co-existing - and partly intertwining one could say. A localist systems-view is married with a univeralist "general solutions"-view. Research that focused too much on economic factors was criticized and a systemic, multi-factor perspective on development was underscored, at the same time as economic factors were actually slightly more underlined than before. Research capacity as emancipatory - a way to independent problem solving - is lifted once again.

The amount of statements to the effect of "this is how you do it", however, increase as well. The problems are global and there are solutions that are relevant to all countries.

In the methods document from 1992, Sarec states that "research capacity is an integrated complex made of intellectual, infrastructural, technical and organizational capabilities, embodied in human beings and material things". ${ }^{830}$ The abilities identified ranged from the individual level to the national level, and these abilities were seen as a precondition for more equality in the international research sphere. Discussions about equality are present, but the new focus - that of sustainable development - seems equally important. This implies an increased focus on local and traditional knowledge, small-scale projects, at the same time as it is very much about globally defined problems and solutions. ${ }^{831}$

Low-income countries are at times explicitly imagined to be following the steps of Sweden, and discussions about what countries "need" become more frequent:

All of us know the important role of science and education for development. The history of Sweden demonstrates that to move from poverty to prosperity a country needs professionals to identify problems, analyse them, propose policies and implement them. ${ }^{832}$

\footnotetext{
${ }^{829}$ Sarec (1994). Sarec Annual Report 1992/1993. p9

${ }^{830}$ Bhagavan, M. R. (1992). The SAREC model: institutional cooperation and the strengthening of national research capacity in developing countries. Stockholm, SAREC. p44

${ }^{831}$ Akin to the concept of glocalization. See for example Featherstone, M., S. Lash, et al. (1995).

Global Modernities, SAGE Publications. P26

832 Sarec (1994). Sarec Annual Report 1992/1993. p6
} 
All countries need a better understanding of how eco-systems function, in particular how to develop sustainable user systems. ${ }^{833}$

The number of scientists and technicians per capita in Sweden is then compared to the ratio in developing countries, and the conclusion is that there is a massive gap in capacity. This is not necessarily controversial; in one sense it is merely saying that knowledge is important. Furthermore, this uneven concentration of resources results in much more research being conducted on the problems of rich people, while for example the health issues faced by poor people are grossly under-researched. The quotes above can be seen as an expression of the universalist discourse in the sense that low-income countries are expected to follow "more developed"/high-income countries. At the same time, the reasoning attached to it is also localist - concerned with using research to reduce inequalities and increase self-reliance. More "indigenous expertise" is needed and less foreign experts. ${ }^{834}$

An example of how Sarec supports democracy and human rights implied more or less explicit critique of the Structural Adjustment Programs (SAPs) implemented by the World Bank and IMF:

Structural adjustment programs are being implemented in many countries, often supported by the World Bank and IMF. The developing country participation in shaping the terms of SAP:s is very limited. Sarec provides support to macroeconomic research with special emphasis on stabilization policies. ${ }^{835}$

This can be seen as an expression of the localist discourse in that Sarec clearly objects to the lack of low-income country involvement and they saw the need to go in as a type of buffer to support research aimed at stabilizing the effects of the programs.

\section{Concluding discussion. Dependency as a way to independence?}

In general one can see a small trend towards highlighting the interests of Sweden in the 1990's compared to the 1970's and 1980's. The policies started discussing mutual interest more, whereas the first two decades focused more actively on the interests of the lowincome countries. As was mentioned above, this was to a certain extent discussed by Sarec, and explained with the argument that it would require too much work for Sarec to involve too many foreign actors for example. Furthermore, they maintained that it was difficult to establish "real" representative low-income country priorities; therefore the available development relevant expertise in Sweden affected the possibilities available for bilateral cooperation. Efforts to make research aid more demand-driven were undertaken towards the middle of the decade as emphasis on all-encompassing institutional support was suggested. The sociotechnical imaginary characteristic of the

\footnotetext{
${ }^{833}$ Sarec (1993). Sarec Annual Report 1991/1992. pp9-10

${ }^{834}$ Sarec (1994). Sarec Annual Report 1992/1993. p6

835 Sarec (1992). Sarec Annual Report 1990/1991. p55
} 
1990 's was quite dramatic and fatalistic. At least one strong research university was envisioned each low-income country; it is self-reliant and has to handle large uncertainty and change in relation to environmental problems and technological development. They do this through increased focus on problem-oriented and cross-disciplinary research and by providing higher education to more people. The aid actor is considered a necessary catalyst to this independent future.

There are, as I have discussed before, several tensions in the policies of research aid. One that keeps on resurfacing both explicitly and implicitly is the fact that self-reliance as a goal and a localist view of development as a method exist at the same time as reliance on high-income country scientific institutions is considered a necessary part of this journey. High-income country trajectories are the model for how development is envisioned in Sarec's policies. There are several ambitions in the policies which are not compatible. Ambitions to make room for new tracks exist, but actually forging them seems difficult.

As Sarec approaches the end of the 1990's, it seems to have begun to find its place within Sida. A new extensive methods document is published and annual reports begin appearing again. 

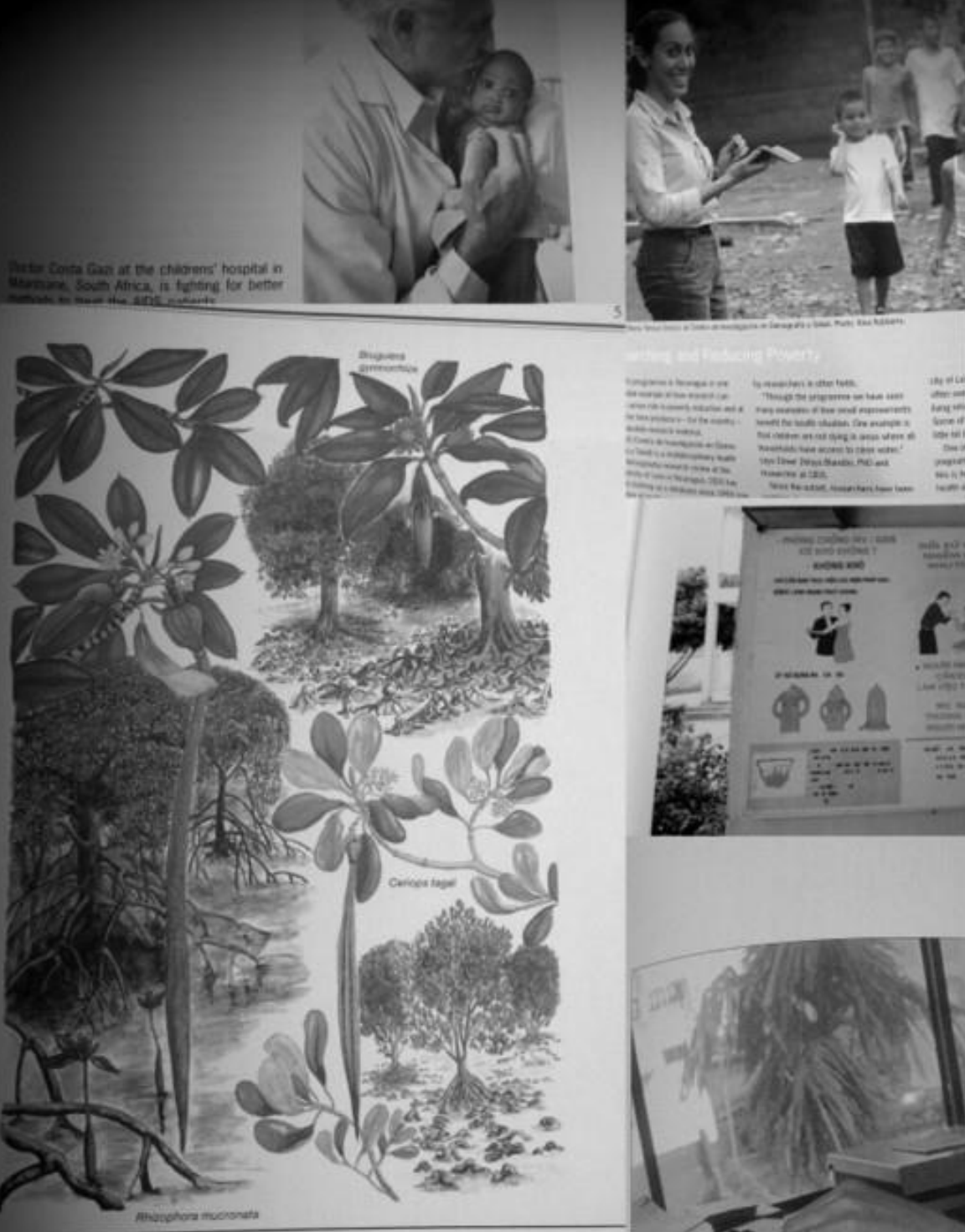

A Sea of ompringtin

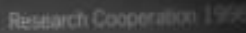
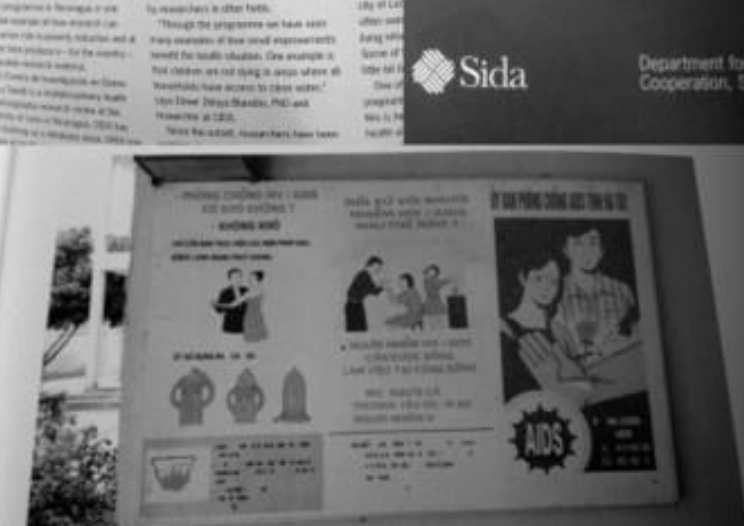

The mave flore and fauna "A guide to the seashores of eastern Africa and the weste "uds" was published as a result of the Marine Science Programme intiated in 1987. made by researchers participating in the programme. (See page 201 .

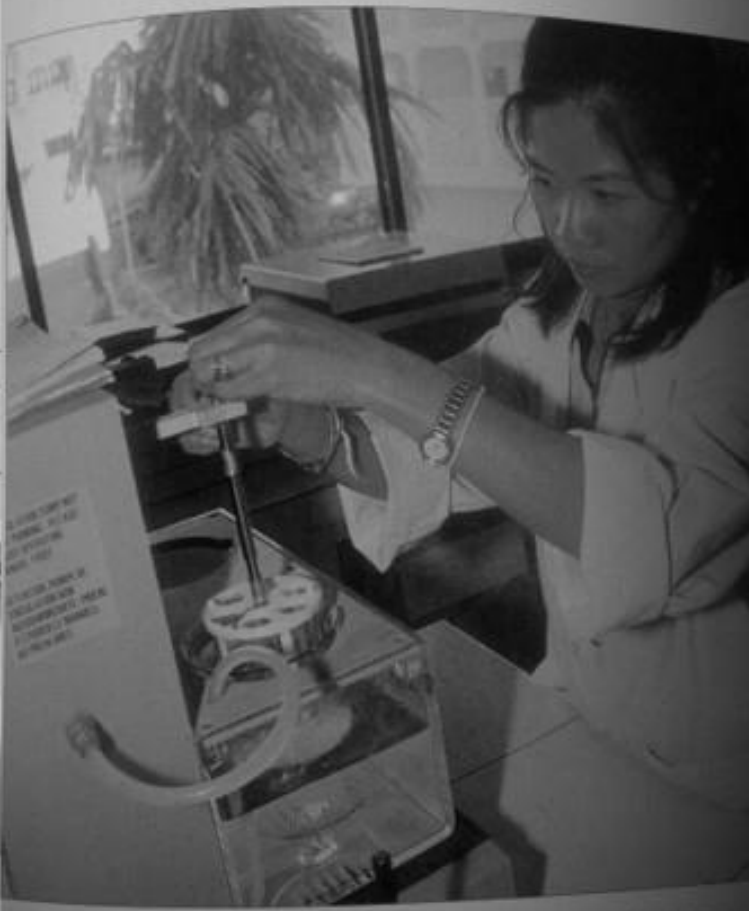

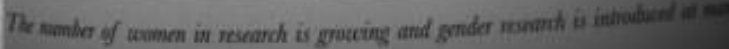




\section{1998-2008: Constructing sustainable knowledge societies}

Access to relevant knowledge, insights into conditions affecting the prevailing situation and capacity for qualified analysis are basic conditions for development. [...] Countries with a vital research community can analyse experiences locally, as well as those gained in other parts of the world thereby identifying opportunities for constructive change and development. ${ }^{836}$

- A Sea of Opportunities, Sida-Sarec annual report 1998

Capacity development is not primarily concerned with filling gaps; it deals with building on what is already there. 837

- Sida's Manual for Capacity Development (2005)

In order to further increase the developmental relevance of its research projects, Sida/SAREC should, without neglecting long-term goals, consider giving a higher priority to projects that are able to directly or indirectly improve conditions for the poor, including projects that are able to increase economic growth in general, while securing an equitable distribution. ${ }^{838}$

- Sida/SAREC Bilateral Research Cooperation: Lessons Learned (2006)

As globalization, information technology and the development of knowledge accelerate, increasing demands will be made on societies to become knowledge societies, i.e. to have the capacity to assimilate external knowledge and to profit from and apply this knowledge. 839

- Research Cooperation I. An Outline of Policy, Programmes and Practice 1998/2000)

This chapter begins when Sarec had been a part of Sida for three years; the new organization had begun to settle in. It continued to be a very eventful time for both foreign aid and research politics in general. Sweden elected a new conservative government in 2006, and one of the areas that was changed rather drastically was foreign aid. Sarec's policy development this decade reflects the diversity of changes occurring within the wider social practices framing Swedish research aid. Investigations, international agreements, and changing national political priorities create a diverse policy landscape; influences from many different directions meet in the central documents of Sarec. As the title of the chapter indicates - the knowledge society takes over as a sociotechnical

\footnotetext{
${ }^{836}$ Sida-Sarec (1999). A Sea of Opportunities. Research Cooperation 1998. p3

${ }^{837}$ Sida (2005). Manual for Capacity Development. p7

838 Boeren, A., T. Alberts, et al. (2006). Sida/SAREC Bilateral Research Cooperation: Lessons

Learned. Sida Evaluation 06/17.p6

${ }^{839}$ Sarec $(1998,2000)$. Research Cooperation I. An Outline of Policy, Programmes and Practice, Sida. $\mathrm{p} 9$
} 
imaginary; and it can be seen as binding the universalist and localist discourses together. This union is tense, however, and adamant defence of local priorities is combined with equally determined use of more or less general "models" for development. Emphasis on systems is stepped up, including systems of innovation towards the middle and end of this period.

The purpose of this chapter is to describe Sarec's research for development discourse between 1998 and 2008. A contextualizing section will introduce the chapter, including a glance into how the concept of capacity building is seen within Sarec's new context, Sida. An analysis of annual reports and policy and methods documents comprises the next section. The chapter then discusses how the evaluations of 2006 portrayed Sarec's activities and rounds off with a discussion on the disbanding of the organization in 2008. I seek to identify what futures are imagined, and how research is perceived to contribute to these. How does Sarec as a boundary organization fit into this equation? ${ }^{840}$

\section{The wider social practice - a snapshot}

Large international development organization policy focused more on the role of science, technology and knowledge for development ${ }^{841}$, and supporting research became a part of the aid agendas of more countries. Odén maintains that some of the most significant events affecting development cooperation and foreign aid around the world were the events of 9/11 in the United States and the wars in Afghanistan and Iraq. ${ }^{842}$ International relations were negatively affected by this, and an increase in unilateral policies (more upholding of national interests) and changing global economic relations (the economic growth of China and India for example) added to this development. ${ }^{843}$ At the same time, global problems like climate change demanded international cooperation, marked by for example the World Summit of Sustainable Development in Johannesburg 2002, ten years after Rio.

There was continued debate concerning which factors were central in order for aid to contribute to development, and discussions were focused on donor coordination and achieving a combination of economic growth and poverty reduction. ${ }^{84}$ The Millennium Development Goals (MDGs) were set in 2000 - poverty was to be halved by 2015 by targeting issues concerning human rights, conflict prevention and democracy. The achievement of the goals were though to depend on significant increases of aid

\footnotetext{
840 The main materials used in this chapter are annual reports (1998-2005), policy and methods documents $\left(1998 / 2000^{840}\right)$, interviews with two former directors and evaluations (2006).

Complementary materials used are smaller evaluations and secondary literature.

${ }^{841}$ Exemplified by things like the UN World Science Conference in 1999, Dahlman, C. and T. e. Vishwanath (1999). World Development Report 98/99: Knowledge for Development, The World Bank. and (2000). Higher Education in Developing Countries - Perils and Promise. The Taskforce on Higher Education and Society. T. W. Bank.

842 Odén, B. (2006). Biståndets idéhistoria: från Marshallhjälp till millenniemål. Lund,

Studentlitteratur. p125

843 Ibid.

${ }^{844}$ Ibid. pp125-126
} 
budgets, not least for countries in Africa. ${ }^{845}$ Several efforts to increase donor coordination and make increase efficiency of support to the low-income countries. The largest of these efforts was the signing of the Paris declaration on aid effectiveness by high- and lowincome countries and international organizations in 2005. Commitments were made regarding ownership, use and strengthening of "receiving" countries' budget systems, and coordination of activities between donors. ${ }^{846}$ Coherence between different areas of politics was also a much debated issue - priorities within one policy area were not to negatively affect priorities in other areas (examples debated were for example agriculture, fishery and trade policies). Concerns were also voiced with regards to the effects of "land-grabbing" and the "race for Africa" by for example China and the US.847 While multipolarity affected the global distribution of power, Western states continued to dominate the agenda of international organizations like the World Bank and the IMF. ${ }^{848}$

In Sweden, a parliamentary investigation called Globkom took place and eventually resulted in a policy for global development (PGD) in 2003 which stated that the general goal for all within all political areas (trade, security, migration, environment, etc., not just foreign aid) should be to contribute to fair and sustainable global development in order to assist in achieving the Millennium goals. ${ }^{849}$ Human rights and the perspectives of the poor were in focus and cooperation between various actors was encouraged. Odén claims that there are similarities between the aid policies of the 1970's and the 2000's in its emphasis on education and health for example, the difference being that the reasons for it. In the 1970's, it was to create employment, and in the 2000's to benefit economic markets. ${ }^{850}$ The PGD was revised by the new government in 2008, and among other things, the central goal formulations were changed to include economic growth.

The discussion about the usefulness of research was turned up at notch during the 2000 's, and with a slightly different direction, according to Benner. ${ }^{851}$ Research became more associated with innovation but the links to application did not happen automatically; a big question therefor became how to go from innovation system to social and political action. ${ }^{852}$ The complexity of the research landscape (including policy) in Sweden is reflective of the presence of many different rationalities and norms, according

\footnotetext{
845 Ibid. p127

846 Ibid. p131

847 Ibid. pp34-35

${ }^{848}$ See for example King, K. (2004). Development Knowledge and the Global Policy Agenda.

Whose Knowledge? Whose Policy? Occasional Paper, . UNRISD Social Knowledge and International Policy-making: Can Research Make a Difference? Centre of African Studies, University of Copenhagen and Wade, R. (2013). "The Art of Power Maintenance. How Western States Keep the Lead in Global Organizations." Challenge 56(1).

${ }^{849}$ (2002). Regeringens proposition 2002/03:122. Gemensamt ansvar: Sveriges politik för global utveckling. p1

850 Odén, B. (2006). Biståndets idéhistoria: från Marshallhjälp till millenniemål. Lund,

Studentlitteratur. pp75-76

${ }^{851}$ Benner, M. (2008). Kunskapsnation i kris. Politik, pengar och makt i svensk forskning, Nya

Doxa. p329

852 Ibid. p329
} 
to Melander. Mode 2 coexists with Mode 1, for example, and the PLACE-norms are complementing CUD0S. ${ }^{853}$ Three research bills were produced in Sweden during this period ${ }^{854}$ The first two - from 2000 and 2004 - discuss research aid more than the last one from 2008. The 2000 bill stated that research aid benefitted the internationalization of Swedish universities, and this in turn positively impacted the preconditions for SidaSarec cooperation with other research councils. The 2004 bill focuses on the policy for global development, and upholds the importance of other research councils than SidaSarec taking responsibility for development-related research. Applied research in general was underlined as being especially important, and particularly applied research within health and medicine. ${ }^{855}$ The research bill from 2008 (the new conservative government's first research bill) encouraged international research cooperation primarily on the basis of a shorter term mutual-interest argument, mentioning countries like China, India, Brazil and South Africa. ${ }^{856}$ Low-income countries were mentioned as important - but as a group - and in relation to Sida's work for capacity development. 857 One interpretation of this is that research cooperation with low-income countries was considered relevant only on the basis of solidarity, not mutual interest.

\section{Sarec within Sida. Building new capacities?}

The concept of capacity building was central in the policies of Sarec from the beginning so one might wonder if there were any changes after the merger with Sida. Around the same time as Research Cooperation I and II came out (1998/2000), Sida published a policy for capacity development as a way of renewing commitment to this method in its work: "Our principal method is capacity and institution development. Knowledge is our most important resource."858 This document also maintained that the relationship between the state, the market and civil society was changing - suggesting that capacity needed to be strengthened in all three parts. ${ }^{859}$ It was not more specific as to what these changes consisted of, but the policy stated clearly that Sida's support to "national systems of education, training, and research" would increase in all projects and programmes. ${ }^{860} \mathrm{It}$ becomes clear from a comparison of policies that though capacity building or development as a method was portrayed somewhat differently by Sida and Sarec, there were also many similarities.

\footnotetext{
${ }^{853}$ Melander, F. (2006). Lokal forskningspolitik. Institutionell dynamik och organisatorisk omvandling vid Lunds universitet 1980-2005, Lund University. pp102-113

854 (2000). Regeringens proposition 2000/01:3 Forskning och förnyelse.,(2004). Regeringens proposition 2004/05:80 Forskning för ett bättre liv. and (2008). Regeringens proposition 2008/09:50 Ett lyft för forskning och innovation.

855 (2004). Regeringens proposition 2004/05:80 Forskning för ett bättre liv. pp190-191

856 (2008). Ett lyft för forskning och innovation. Regeringens proposition 2008/09:50. T. S. Government. p205

857 Ibid. p234

${ }^{858}$ Sida (2000). Sida's Policy for Capacity Development a Strategic Question in Development

Cooperation $\mathrm{p} 8$

859 Ibid. p9

860 Ibid. p10
} 
Capacity was defined as "the conditions that must be in place, for example knowledge, competence, and effective development-oriented organizations and institutional frameworks, in order to make development possible." 861 The policy for capacity development also discussed definitions of various concepts relevant to capacity building. One example of this was the distinction between knowledge transfer and knowledge development, where the policy stated that the two concepts represented two different approaches to the learning process. The idea of knowledge transfer was compared to traditional technology transfer - the import of "ready-made" technology from high-income countries to low-income countries. Knowledge development, on the other hand, was seen as valuing the process of social interaction between different actors - rejecting the idea that there any ready-made solutions exist that fit everywhere. ${ }^{862}$ The policy urged Sida staff to conduct detailed contextual analyses in the planning phases of projects, bearing in mind a systems perspective as represented by the model of capacity building. ${ }^{863} \mathrm{~A}$ way to operationalize this would be to use checklists as the one exemplified below:

\section{Overall problem: Human rights are not respected in the police force}

\begin{tabular}{|c|c|c|c|}
\hline & \multicolumn{3}{|c|}{ Reasons why policemen do not respect human rights } \\
\hline & $\begin{array}{l}\text { Don't know what to do } \\
\text { (= lack the knowledge) }\end{array}$ & $\begin{array}{l}\text { Don't want to do it, } \\
\text { or not allowed to do it. }\end{array}$ & $\begin{array}{l}\text { External limitations } \\
\text { (money or material). }\end{array}$ \\
\hline Individual level & $\begin{array}{l}\text { - Lack of knowledge } \\
\text { about human rights } \\
\text { - Lack of knowledge about } \\
\text { police methods, e.g. } \\
\text { methods of interrogation } \\
\text { (which might lead to the } \\
\text { use of force to make a } \\
\text { suspect confess). }\end{array}$ & $\begin{array}{l}\text { - Believe that criminals } \\
\text { have forfeited their rights. } \\
\text { - Consider the traditions of } \\
\text { their own ethnic groups to } \\
\text { be superior (e. g. in respect } \\
\text { of women's rights). } \\
\text { Their own living and working } \\
\text { conditions are not in } \\
\text { accordance with human } \\
\text { rights standards, e. g. the } \\
\text { staff quarters are as bad } \\
\text { as the lock-ups. }\end{array}$ & $\begin{array}{l}\text { - Lack of tools, e.g. for } \\
\text { examining the scene of } \\
\text { the crime, for taking } \\
\text { fingerprints, and so on. } \\
\text { - The wrong equipment, } \\
\text { e. g. automatic weapons } \\
\text { instead of batons. }\end{array}$ \\
\hline Organisational level & $\begin{array}{l}\text { - There is no human rights } \\
\text { perspective in the ordinary } \\
\text { police training. }\end{array}$ & $\begin{array}{l}\text { - The police authorities } \\
\text { o not take action against } \\
\text { violations of human rights } \\
\text { by policemen. } \\
\text { - Corruption among police } \\
\text { management. }\end{array}$ & $\begin{array}{l}\text { - Lack of resources for } \\
\text { improving the condition } \\
\text { of the lock-ups. (e. g. } \\
\text { latrines, sleeping mats). }\end{array}$ \\
\hline $\begin{array}{l}\text { The institutional } \\
\text { framework }\end{array}$ & $\begin{array}{l}\text { - There is no clear division } \\
\text { of responsibilities between } \\
\text { the authorities where } \\
\text { education and training in } \\
\text { human rights is concerned. }\end{array}$ & $\begin{array}{l}\text { - The penal code has not } \\
\text { been reformed in } \\
\text { accordance with the human } \\
\text { rights conventions (e.g. } \\
\text { corporal punishment...) }\end{array}$ & $\begin{array}{l}\text { - Other authorities do not } \\
\text { fulfil their obligations (e. g. } \\
\text { the court proceedings for } \\
\text { detained persons are not } \\
\text { carried out within the time } \\
\text { laid down in the law). }\end{array}$ \\
\hline
\end{tabular}

Figure 6: Matrix for assessing capacity development needs

861 Ibid. p9
862 Ibid. pp18-19
863 Ibid. p21-23 
All manner of problems are framed from a capacity perspective, in this example illustrated with an assessment of the needs for capacity development in a police force in order to prevent human rights violations. ${ }^{864}$

Five years later, in 2005, a manual for capacity building was published with the goal to further concretize how staff at Sida were to work with the method, how to do the contextual analyses and decide on appropriate measures. It was document to guide Sida employees in their planning daily work. The report aimed to answer a number of questions, for example: "How can we, as outsiders, contribute to something which basically concerns learning and which must grow from the inside? What should the interaction between partners look like? Which role should and can Sida play?"865 These questions highlighted the importance of context-specific development, and pointed to the potential problem of attempting to contribute to local processes from an external point of view. ${ }^{866}$ To make the demand-driven and context-sensitive aspect clear, the manual underlined the difference between capacity development and capacity building, where the latter implies that there was nothing there to begin with. Capacity, the manual states, has to grow from the "inside" - though certain stimulus from "outside" can help. ${ }^{867}$

These issues were further problematized with a reference to the need to work more intensively with other donors - having different definitions of what capacity was and how to build capacity could be a challenge. At the same time, the manual states that the focus on capacity and cooperation as opposed to knowledge and technology transfer among donors had only become clear in the late 1990's/early 2000's, and that the level of agreement surrounding its meaning was increasing. 868

The manual's model for analysis is similar to the on in the policy for capacity development document from $2000,{ }^{869}$ portraying capacity as consisting of the following levels:

\footnotetext{
${ }^{864}$ This was an "analytical tool" presented, "intended to provide guidance in project preparation and project assessment. It shall assist Sida staff and other actors to define needs for capacity development. It will thus help to identify factors that are important for sustainable development." Sida (2000). Capacity Building - Sida Working Paper No 4. Analysis of Needs for Capacity Development. , Department for Natural Resources and the Environment, Policy Secretariat for the Sector Departments. pp1\&3

865 Sida (2005). Manual for Capacity Development. Foreword

866 Ibid. Foreword \& p6

867 Ibid. p13

868 Ibid., Foreword, pp6 \& 11

${ }^{869}$ Sida (2000). Sida's Policy for Capacity Development a Strategic Question in Development Cooperation p21
} 


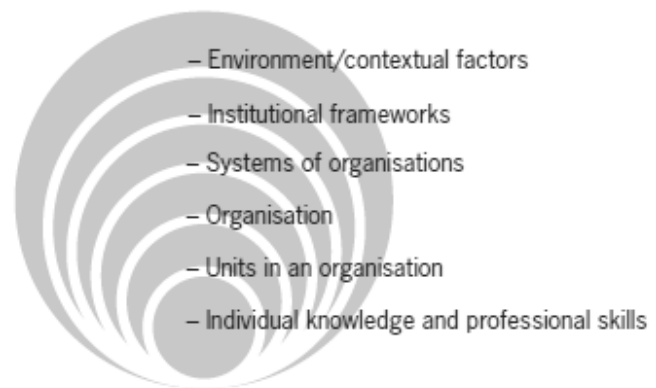

Figure 7: Sida's model of capacity

This discussion is very similar to the one in Sarec's own policies. The different levels are then discussed in turn, focusing on five points of departure and what examples of questions that can be asked in order to assess current capacities and decide on appropriate measures and methods. This approach is also compared to previous capacity-oriented measures, which according to the manual had until the end of the 1980's focused more heavily on individual capacity. 870 The guidelines in the manual were quite vague in one sense and very concrete in another. Each context is portrayed as unique, so the list of assessments to be complete prior to "engaging" would potentially be very long.

Capacity development is thus both a goal and a means to achieving goals throughout all development cooperation... there are no ready-made solutions to the problem or how individuals, groups or organizations can develop their capacity. Sida works in extremely complicated environments and the needs for capacity have to be analysed on the basis of their specific context. ${ }^{871}$

Capacity building is here said to be both a goal and a method, something which exemplifies the plasticity of the concept. The quote above might imply that the manual remains relatively general, yet it gets very specific as it breaks down this broad ambition into concrete recommendations. One of this chapter's introductory quotes from the manual discussed above suggests that capacity development does not focus primarily on filling

Motivation staircase

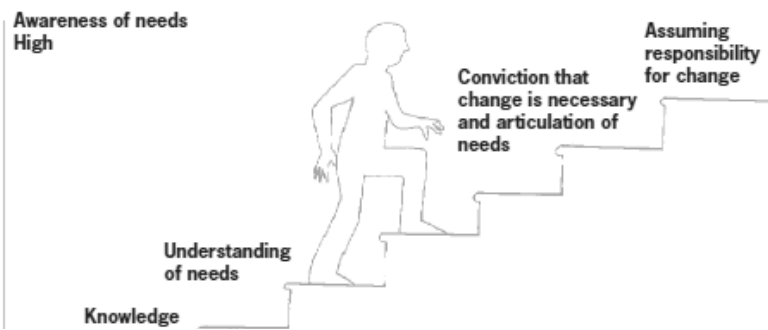

Figure 8: The motivation staircase gaps. Later on in the same document, however, it is suggested that staff identify existing capacity gaps in organizations and that these should serve as points of departure. ${ }^{872}$ This might illustrate that it is difficult to be a careful outsider as well as a productive "aider" or cooperative partner. ${ }^{873}$ The

\footnotetext{
${ }^{870}$ Sida (2005). Manual for Capacity Development. pp7-8 \& 15-16

${ }^{871}$ Ibid. p12

872 Ibid. p39-40

${ }^{873}$ See ibid. p58 for another discussion on gap-filling.
} 
manual also includes a figure depicting a person's staircase of motivation in the context of discussing continuous learning and incentives for change (see fig 8).

One could argue that this staircase is incompatible with the idea of contextdependence. ${ }^{874}$ The figure might give the impression that this motivation process is true for all people and situations. Figures like these are necessarily simplified, yet they nonetheless convey and or cement ideas of how things work, and one might argue that the origin of these ideas are highly relevant in the aid context. The manual contained several models and definitions relating to learning, how organizations work and so on at the same time as it stated that there are no set models and all situations needed to be tailor-made. ${ }^{875}$ It seems to be difficult to be both context-flexible and prescriptive at the same time. This is a theme that also can be followed in the subsequent evaluations of capacity development policies.

The policy and the manual for capacity development were of central kind at Sida, but several evaluations and working papers on the topic were also produced during this decade. One of these was a report published just one year after the manual, in 2006. It was based on a two day seminar in Stockholm held in order to discuss mainly the effects on Sida's capacity development approach of Sweden's Policy for Global Development (PGD) and the Paris Declaration.876 The seminar discussions underlined a need to strengthen the notion of capacity development as an "endogenous process that can be stimulated, but not engineered, from outside." 877 One of the conclusions was that these two policies (PGD and Paris Declaration) created considerable challenges for Sida's work with capacity development since they prioritized potentially competing aspects of capacity.

Apart from the need for improved donor coordination, the concern was that the more directly pro-poor capacity development discussed in the PGD might be outmanoeuvered by the capacity discussed in the Paris Declaration - which focused more on the capacity of governments and other national actors to manage finances. ${ }^{878}$ The report included summaries of discussions, but also texts authored by presenters at the seminar, and thus provided many different perspectives on capacity development:

Sida and other donors need to let go of the control approach and instead look more for opportunities for learning, thereby allowing for much more flexibility in our support. We must let go of the underlying notion of viewing Sweden as the norm.

\footnotetext{
874 Thought it would be easy to do, it would be wrong to call it universalistic in this context, since that would imply drawing a strong parallel to Sarec's policies, but this is Sida's discourse. I cannot see that Sarec's universalist and localist discourses clash in any significant manner in relation to the importance of capacity building. It does not go into this kind of detailed discussion (both discourses assume that local/national research capacity is necessary for all kinds of reasons), their differences become more visible in other aspects, as the discussion in the empirical chapters has shown.

875 Sida (2005). Manual for Capacity Development. pp39-40

${ }^{876}$ Sida (2006). Time for Rethinking. Capacity Development in a Changing Landscape of

Development Cooperation. p5

877 Ibid. p6

878 Ibid. pp6-7
} 
Consequently, we should not only use Swedish resources in the programmes. There are additional possible solutions, such as tripartite, south-south and local consultants. ${ }^{879}$

Capacity is such a strange concept. It does not fit well into a system of bureaucratic control. [...] Although it is acknowledged to be important, it is not deemed important enough to make the agencies change their procedures to deal with it in a serious way. 880

There are more examples, but what the quotes above seem to reflect is a lack of faith in the method of capacity development as it was being used by development agencies - due to path dependence for example. Certain ideas - explicit or implicit - were not seen as compatible with capacity development - such as upholding Sweden as the norm, or using Swedish resources where better ones may be found in other countries. Development agencies in general were seen as not committing well enough to the policies in this area. The authors of the second quote also lamented the growing focus on measurable results in aid, claiming that capacity is difficult to evaluate since it "relates to issues with little specificity or visibility, such as legitimacy, 'positioning', empowerment, relationships (social, personal, professional), trust, dialogue, protecting space, volition, identity." ${ }^{81}$ It may or may not be a contradiction, but there were many references to the need for more flexibility in the method of capacity development, yet one of the concluding remarks of the report was that more concrete tools were needed. ${ }^{882}$ The policy and manual for capacity development do not seem to have been revised since. ${ }^{883}$

There had clearly been a considerable amount of discussion going on about capacity building - including a push to emphasize a systems perspective and contextspecific measures - not least since the late 1990's. The story told above illustrates the complexity of balancing different policies and demands (demand- or supply-led, resultsor process-orientation, management capacity or more directly pro-poor capacity). The tale could continue, but suffice it to say that capacity building seemed to be contentious concept in the 2000's, quite different in what it entailed when compared to Sarec's earlier

\footnotetext{
${ }^{879}$ Ibid. p17

${ }^{880}$ Ibid. p31

${ }^{881}$ Ibid. p34

882 The report lifts Sarec as the actor within Sida with most experience in building endogenous capacity within the area of research, but it does not delve very deep into how this can contribute to the wider discussion.

883 The Swedish National Audit Office conducted an evaluation in 2009 of Sida's capacity building efforts in relation to public administration in partner countries. The report was very critical and suggested among other things that Sida had consistently failed to conduct adequate assessments of the existing capacity before starting new programmes. Furthermore, it stated that efforts often lacked adequate goals and monitoring plans. The manual for capacity development was not seen as concrete enough and not sufficiently aligned with the Paris Declaration.

Riksrevisionen (2009). Sida's support for capacity development in the public administration of partner countries. RiR:2009:15 Summary, pp3-5
} 
use of it for example. ${ }^{884}$ Kjellqvist maintains in his dissertation that this late form of capacity building conceptualization within Swedish aid had forgotten the human and material aspects and risked increasing dependencies instead of the reverse. 885

\section{Localist universalism continued. Evolving modes of support and priorities.}

Sarec's priorities were more clearly outlined in the official policy and methods documents from the 1990's and onwards. 886 The picture of the priorities becomes more nuanced and complex when also taking into account the annual reports, evaluations and interviews. This particular period's annual reports - in contrast to previous years - had a different kind of titles, highlighting certain aspects of research aid. A Sea of Opportunities, for example, refers positively to all the possibilities that research aid had created since Sarec's inception, and Research for Life focuses on the importance of all kinds of healthrelated research. ${ }^{887}$

As with the organizational changes implied by the merger 1995, Sarec stopped publishing annual reports when the government decided to reorganize Sida. Resources were prioritized differently at times like that. For the period of 2006-2008, I have looked at Sida's annual reports and some smaller research-related evaluations instead, though not all of them have been explicitly used in the chapter.888 As with the period 1995-1997, the information on the research aid activities in Sida's reports tended to be less detailed than in Sarec's reports. They nonetheless provide interesting snapshots of continued activities and issues, such as illustrated by the quotes below from Sida's annual reports 2006, 2007 and 2008:

Ideas about knowledge driven economic development has reached the aid debate in recent years, increasingly pointing at the value of research and development.

\footnotetext{
${ }^{884}$ See for example Kjellqvist, T. (2013). Biståndspolitikens motsägelser om kunskap och tekniköverföring - från konkret praktik till abstrakt policy. doctoral dissertation series, Blekinge Institute of Technology. pp271-272

885 Ibid. p272

886 For example Bhagavan, M. R. (1992). The SAREC model: institutional cooperation and the strengthening of national research capacity in developing countries. Stockholm, SAREC., Olsson, B. (1992). The Ownership and Cultivation of Knowledge. The rationale for Swedish support to universities in developing countries. Sarec., Sarec $(1998,2000)$. Research Cooperation I. An Outline of Policy, Programmes and Practice, Sida., Sarec $(1998,2000)$. Research Cooperation II. Trends in Development Research, Sida.

${ }^{887}$ Sida-Sarec (1999). A Sea of Opportunities. Research Cooperation 1998. p3

888 Such as Johansson de Château, L. and S. Billfalk (2007). Building Research Partnerships - an evaluation of the Swedish Research Links programme., Asingwire, N., S. Kyomuhendo, et al. (2008). Sida's Support to the Agency for Cooperation and Research in Development (ACORD) to the HIV and AIDS Support and Advocacy Programme (HASAP) in Uganda., and Sundin, P., B. Göhl, et al. (2008). The Asian Regional Research Programme on Environmental Technologies (ARRPET).
} 
Sida's experience of the area is unique thanks to the systematic and long-term support it has provided to research institutions. ${ }^{889}$

Few donors have developed mechanisms for bilateral research support. The research supported is mainly for knowledge development and go to either international or regional research programs or to projects which are applied for and managed by the countries' own researchers. [...] With growing preconditions in the cooperating countries it is reasonable to expect bilateral research cooperation to grow amongst other funders. ${ }^{890}$

Investments in research contribute to economic growth in many different ways. Academic research increases capacity to solve scientific and technical problems and creates new instruments and methods. Research contributes to higher quality in the education of students and thereby to increasing the level of knowledge of the workforce in general. ${ }^{891}$

The Sida reports continue to uphold the two-pronged strategy of contributing to research capacity building and supporting development research. One can find similar types of arguments as in the Sarec reports, except they are presented in a more condensed manner. Long-term capacity building and the importance of coordination with other donors is highlighted given the increasing attention being given to research for development. Sida-Sarec's experience is upheld as unique and empancipatory in this context, other donors were expressing interest in following their bilateral cooperation example - and rightly so, according to Sida.

Research Cooperation I and II - the policy and methods documents from 1998 and 2000 - were produced in order to lay out guidelines for all activities at Sida concerning research, and to present the central ideas and methods concerning research aid activities. Furthermore, the publications were intended to serve as a basis for comments, debate and discussion on the principles and practices of aid to research.892 A distinction is made between research as a support function versus research as a subject for support, where the latter involved capacity building and support to thematic research (Sarec's main task). The research as support function was more short-term and directly linked to the need for new knowledge in relation to development projects. ${ }^{893}$

${ }^{889}$ Sida (2006). Årsredovisning. p61

${ }^{890}$ Sida (2007). Årsredovisning. p68

${ }^{891}$ Sida (2008). Resultatbilaga till Sidas årsredovisning 2008. p50

${ }^{892}$ Sarec $(1998,2000)$. Research Cooperation I. An Outline of Policy, Programmes and Practice, Sida. pp3-4

${ }^{893}$ Most funds for research were for research as a subject for support and went through Sarec ( 670 of the 700 million crowns going to research in 2000). Other research activities (research as support function) at Sida were included in the standard development programs or funding of research for internal use. There still was still a separate Sarec budget, though some of the research cooperation projects had begun being incorporated into Sida's country strategies. The part of the budget that went to Sida's standard development programmes was used to produce impact studies and evaluations for example. Ibid. pp7, 10 \& 34 
Research capacity is framed as necessary for producing knowledge for "positive and sustainable development, including the eradication of poverty." 894 Scientific knowledge is essential; it can improve agricultural yields and health care, it can alleviate environmental problems, promote democratic processes and prevent conflicts for example. ${ }^{895}$ Research is portrayed as being important for three main reasons; one being that it enables locally relevant knowledge production (including the ability to make use of "general knowledge" and international research findings) as a means to solve national problems. The second reason was that universities are "important cultural institutions and constitute one of the most important forums for critical analysis and debate on various social conditions." 896 Finally, research capacity is also seen as contributing to the quality of higher education. ${ }^{897}$ These reasons will sound familiar by now, indicating a kind of stability in the policy over the decades. Nevertheless, ideas about which activities contributed to these goals continued to evolve and some novel conceptualizations developed this decade. As the chapter's beginning alluded to, the policy envisions research as crucial part of knowledge societies. Higher education and research are considered important parts of a country's knowledge system which in turn involves interaction and links with the rest of society as important factors. ${ }^{898}$

Sarec's overarching goal was to "strengthen the research capacity of developing countries and to promote development-oriented research," 899 and they did so mainly through supporting bilateral cooperation (building national research capacity) and thematic research (which mainly consisted of support to international and regional research organizations). Research capacity was seen as a prerequisite for being able to conduct development-relevant research, but the two modes of support were seen as often overlapping. In other words, the policies uphold that there are usually capacity building aspects to the thematic support and bilateral support could include support to development-related research projects (results).

Between 55 and $63 \%$ of the research aid budget during this decade was allocated to thematic research, and between 25 and $32 \%$ to bilateral support. Swedish development research was allocated between 8 and $12 \% .{ }^{900}$ Africa was the prioritized continent. ${ }^{901}$ Some examples of activities supported are listed in the table below. It is worth noting that although the annual reports are quite informative, the level of detail when it comes to description of activities in different countries varies greatly. The annual reports from 2004 and 2005 were organized more thematically than the other ones for

\footnotetext{
${ }^{894}$ Ibid. p7

${ }^{895}$ It is also pointed out that these do not just represent acute problems. Ibid. p8

896 Ibid. p9

${ }^{897}$ Ibid. p7

898 Ibid. pp9\&12

${ }^{899}$ Ibid. p10

${ }_{900}$ A summary of the statistics provided in the annual reports between 1998 and 2005 .

901 The countries that Sarec worked with (as of 1999) were Eritrea, Ethiopia, Mozambique,

Tanzania, Zimbabwe, India, Sri Lanka, Vietnam and Nicaragua, and 130 Swedish university departments were involved in bilateral cooperation (Sarec $(1998,2000)$. Research Cooperation I. An Outline of Policy, Programmes and Practice, Sida. p33)
} 
instance. The 2005 report was the most differently organized - being divided into sections based on the Millennium Development Goals and how Sarec activities contributed to the achievement of these. This is interesting in that it provides different perspectives on what Sarec did, but it also makes it more difficult to get an overview of all the things being done within one mode of support and/or in one country any given year. Funds spent are reported according continent or thematic area rather than per organization.

The 1990's saw a reduction in priority of social sciences and the humanities within Sarec's activities for example; natural sciences and technology, health and agricultural research dominated the agenda. By 2001, however, renewed interest in social science perspectives on development and poverty reduction was expressed, not least since low-income countries had to write poverty reduction strategy papers (PRSPs) in order to get loans from the IMF and the World Bank. ${ }^{902}$ It is an example of how a boundary organization had to balance demands from both the academic and political spheres.

\section{Mode of support $\quad$ Example activities}

Bilateral Cooperation $\quad$ Support to strategic planning for university development in Mozambique. 1998 marked 20 years of cooperation with and results at Eduardo Mondlane University (UEM) included many trained staff, a stronger institution and a significantly reduced dependence on external teaching staff. Focus turned to lessening dependence on external finances through development of strategic plans alongside continued institutional support and support to research training. Some supported areas included: anthropology, biotechnics, chemistry, history, engineering, law, marine biology, medicine, and physics. Some of the institutions involved from Sweden: Chalmers University, Göteborg University, Karolinska Institute and Lund University. Other universities: University of Pretoria and University of Durban, South Africa, University of Northcumbria, UK. ${ }^{903}$

Support to research in Bolivia focused on the public university work on policy and research management at Universidad Mayor de San Andrés (UMSA) in La Paz and Universidad Mayor de San Simón (UMSS) in Cochabamba. Lecturers were enrolled in $\mathrm{PhD}$ training, research teams were formed and certain infrastructure support was provided. Projects going on were within history, archaeology, environmental science, chemical engineering and biogas research. Institutions involved included: Lund University and Uppsala University, Sweden. The Latin American Faculty of Social Sciences

902 PRSP's replaced the much criticized structural adjustment programs (SAP's). See for example Craig, D. and D. Porter (2003). "Poverty Reduction Strategy Papers: A New Convergence." World Development 31(1): 53-69.

903 Sida-Sarec (1999). A Sea of Opportunities. Research Cooperation 1998. p10 and Sida-Sarec (2004). Research Cooperation 2003. Forging Links. p14 


\begin{tabular}{|c|c|}
\hline & $\begin{array}{l}\text { network (FLACSO) and the Bolivian Center of Multidisciplinary } \\
\text { Studies (CEBEM).904 } \\
\text { Information and communication technology (ICT) projects as part of } \\
\text { bilateral cooperation. Universities were seen as important "focal } \\
\text { points" for ICT in society in the struggle to overcome the "digital } \\
\text { divide", hence both Sida and Sarec were in different ways } \\
\text { contributing to building "ICT backbones" in the low-income } \\
\text { countries. Sarec's emphasis was to ensure the connectivity of } \\
\text { universities. Examples: Universities in Sri Lanka, Tanzania, } \\
\text { Mozambique, Ethiopia, Zimbabwe, Uganda, Vietnam, Nicaragua and } \\
\text { Bolivia collaborated with Stockholm University, Uppsala University } \\
\text { and Lund University in Sweden and University of Delft, The } \\
\text { Netherlands.905 }\end{array}$ \\
\hline $\begin{array}{l}\text { Thematic research } \\
\text { programmes: } \\
\text { International research } \\
\text { organizations, regional } \\
\text { cooperation, Swedish } \\
\text { development research } \\
\text { and special initiatives }\end{array}$ & $\begin{array}{l}\text { Swedish research links (2002-ongoing). Regional research } \\
\text { cooperation between countries in Asia and South Africa and Swedish } \\
\text { universities. Funded by Sida and administered by the Swedish } \\
\text { Research Council in cooperation with other research councils. Its' } \\
\text { main aim was/is to promote internationalization of Swedish research } \\
\text { through cooperation with developing countries (middle-income } \\
\text { countries mainly) focused on results and based on mutual interest.906 } \\
\text { Support to BIO-EARN (The East African Regional Programme and } \\
\text { Research Network for Biotechnology, Biosafety and Biotechnology } \\
\text { Policy Development): A regional research network through which } \\
\text { researchers from Ethiopia, Kenya, Tanzania and Uganda built } \\
\text { capacity within biotechnology issues and promoted research and } \\
\text { policies in order to minimize the risks with biotechnology and } \\
\text { sustainably improve livelihoods and food security.907 } \\
\text { Support to organisations that provide grants for regional research } \\
\text { councils like CLACSO, the Latin American Council of Social Sciences, } \\
\text { CODESRIA, the Council for Development of Social Science Research in } \\
\text { Africa, OSSREA, the Organisation for Social Science Research in } \\
\text { Eastern and Southern Africa and APISA Asian Political and } \\
\text { International Studies Association. This enables funding for research }\end{array}$ \\
\hline
\end{tabular}

904 Sida-Sarec (2004). Research Cooperation 2003. Forging Links. p23

${ }^{905}$ Sida-Sarec (2001). Science for Development - Searching for Keys to the Future. Research Cooperation 2000. p21, Sida-Sarec (2002). Towards Freedom from Poverty. Research Cooperation 2001. p21 and Sida-Sarec (2005). Research Cooperation 2004. Research Makes Sense. pp22-25

906 Johansson de Château, L. and S. Billfalk (2007). Building Research Partnerships - an evaluation of the Swedish Research Links programme.

907 Sida (2006). Biotechnology and the Future of Africa. A presentation of the BIO-EARN Programme. pp2-3 


\begin{tabular}{|l|l|}
\hline $\begin{array}{l}\text { and stronger links between researchers and policymakers in low- } \\
\text { income countries and regions. }\end{array}$ \\
$\begin{array}{l}\text { With the support of Sida-Sarec, Swedish researchers took } \\
\text { responsibility for the secretariat for the Multilateral Initiative on } \\
\text { Malaria (MIM). It had as a goal to intensify efforts to combat malaria } \\
\text { through cooperation with WHO, the U.S. National Institute of Health, } \\
\text { the Global Fund, the European Union's European and Developing } \\
\text { Countries Clinical Trials Programme (EDCTP) and the European } \\
\text { Malaria Vaccine Initiative. The secretariat was also supported by the } \\
\text { Swedish Research Council, the Swedish Foundation for Strategic } \\
\text { Research. Activities included mobilizing researchers from different } \\
\text { disciplines in international, regional and bilateral research } \\
\text { cooperation. }{ }^{909}\end{array}$ \\
\hline
\end{tabular}

\section{Strengthening entire institutions}

The idea of one university per country was launched in the early 1990's and had become central in the policies of this decade. The argumentation for having one research university per country continued to be based on the same kind of reasoning as in Olsson's position paper from 1992 (discussed in chapter 7). ${ }^{910}$ A systemic view of the role of research in development is put forth in the policy and methods document from the beginning of the decade. Sarec argues, with high-income country universities as the comparison, that the building of national capacity requires supporting the "whole":

While research, in advanced countries, is considered to be of strategic importance for economic growth and development, such a connection is less obvious in poor, developing countries. The impact of research is rarely direct and immediate. Research projects that lead to sensational breakthroughs invariably build on a significant amount of earlier research. Applied research is based on a solid basis of theories and methods and on a cadre of researchers following research in relevant disciplines. In poor countries, where such a basis is very weak, the likelihood of producing applied research of reasonable quality is meager. When endeavouring to build up an essential basis of national research, it is not enough to look for individual research skills, the whole "architecture for research" must be considered.911

One of the most important tasks of the university, according to Olsson, was the contribution to the quality of higher education; an increased number of qualified

\footnotetext{
${ }^{908}$ Sida-Sarec (2005). Research Cooperation 2004. Research Makes Sense. p29

${ }^{909}$ Sida-Sarec (2004). Research Cooperation 2003. Forging Links. p46

${ }^{910}$ Before Berit Olsson became director, she was responsible for idea of one university per

country.

${ }^{911}$ Sarec $(1998,2000)$. Research Cooperation I. An Outline of Policy, Programmes and Practice, Sida. p22
} 
researchers were able to teach, and also made current research a part of the education. ${ }^{912}$ At the same time, it was important to highlight higher education and research as separate issues due to trends within foreign aid in general:

Somehow it seemed like foreign aid in general had this idea that universities in lowincome countries should teach - not do research. Certain individuals can get a chance to do research, but not the universities in general. So we decided that each country needs a research university. There should be at least one university which can both teach and "reproduce its own capacity."

Sarec framed universities as a part of a country's knowledge system, and the aid actor (Sarec) contributes to development by both strengthening research capacity at universities (through bilateral support) and supporting development research (through thematic support). Different levels of capacity are defined in Sarec's policy and methods documents; individual, institutional, national, regional and international. ${ }^{914}$ Universities are seen to have many roles, and though Sarec's policies focus on research, other important roles are often mentioned as well, like provision of higher education and contribution to democratic development. The figure below aims to illustrate how Sarec's policies construct how research aid contributes to development.

The end goal: $\quad$ Strong universities within national knowledge systems that: provide better higher education; are able to produce locally relevant knowledge; can make use of externally produced knowledge; collaborate more with other actors in society; and can contribute to sustainable development and poverty reduction

Expected outcome: Produce research results Build research capacity

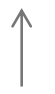

Sarec's modes of support:

Activities:

\section{Regional research \\ International research \\ Swedish research}
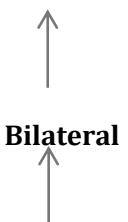

\section{Research training organization/infrastructure policy and management}

Figure 9: Research aid as portrayed by Sarec's policy.

\footnotetext{
912 Transcription (2009). Interview with Berit Olsson 092509. p18

913 Ibid.

914 Sarec $(1998,2000)$. Research Cooperation I. An Outline of Policy, Programmes and Practice, Sida. p23
} 
Many other agencies, stated Olsson, tended to focus on quite narrow and thematic support instead of institutional capacity building. ${ }^{915}$ If one wants to support capacity building, Olsson maintained, it is better to approach a university and ask "in what way can our agency best support your university development plans?"916 This way, structures and processes are supported without a priori steering which the priorities should be; something which she meant was fairly common when thematic assistance was offered. Thematic support tended to be more specific and narrow she said, more tied to the donor countries interests and expertise (and not necessarily something which will contribute to the capacity of the university). Olsson also considered it important to coordinate amongst donor agencies together with the low-income countries in question in order to make efforts effective and relevant. ${ }^{917}$

Sandwich training remained the main method through which to contribute to individual capacity building, where the $\mathrm{PhD}$ students spent time both in their home country and at institutions in Sweden. Since the sandwich program included an intention to counteract brain drain, it is interesting to note that the GlobKom investigation warned Swedish Universities not to attract students and PhD's from low-income countries. This was in the context of suggesting that Swedish universities should take more responsibility for including low-income countries in their internationalization strategies and not just rely on aid money. ${ }^{918}$ It could be seen as a manifestation of the tension between values and policies coupled to aid versus those related to research.

Based on the view of the enabling capacity of new information and communication technologies (ICTs), Sida and Sarec supported the development of ICT infrastructure at universities. This was seen to enable more efficient communication between researchers as well as to improve access to scientific publications. ${ }^{919}$ New ICTs were also considered as having many potentially positive impacts on education (distance learning, student active learning, etc) and the administrative capacity of the universities could be significantly improved (regarding student registration, library information systems, website management etc). In general, universities were considered focal points, they could play an important role for the countries ICT development. ${ }^{920}$

\footnotetext{
915 And other actors, like the World Bank, has pushed for privatizing reforms within higher education in low-income countries, treating knowledge as a private rather than a public good. According to a book by history researcher Mahmood Mamdani, such reforms at Makerere University in Uganda resulted in several problems. Mamdani, M. (2007). Scholars in the Market Place. The Dilemmas of Neoliberal Reform at Makerere University 1989-2005, the Council for the Development of Social Science Research in Africa (CODESRIA). 916 Transcription (2009). Interview with Berit Olsson 092509. p23

917 Ibid.

918 Globkom (2002). En ny svensk politik för global utveckling (SOU 2001:96). ,.pp96-97

${ }^{919}$ Sarec $(1998,2000)$. Research Cooperation I. An Outline of Policy, Programmes and Practice, Sida. p16

${ }_{920}$ Sida-Sarec (2005). Research Cooperation 2004. Research Makes Sense. pp23-25
} 


\section{Thematic research}

Thematic support could only modestly contribute to sustainable development, maintained Sarec. This kind of support was framed as a supplement to - and enhancement of - the support to national capacity building (bilateral support). ${ }^{921}$ Thematic research was called "research for developing countries" whereas bilateral support was "research within and by the countries." 922 Sarec continued to distinguish very clearly, in other words, between the different modes of support and the kind of knowledge production they entailed. The effects of thematic research (general knowledge aimed at being relevant for many contexts) were not considered optimal, as exemplified by the quotes below:

The purpose of these programmes [such as the WHO and CGIAR] is to provide an overview of existing knowledge and research, to identify neglected research areas, promote relevant research on such gaps, and to translate research findings into recommendations for different situations. Unfortunately, the impact of such findings has been marginal in many of the least developed countries. They have limited capacity to follow and make use of new knowledge, as well as limited capacity to participate in and influence international research. As evident from the development literature, problem formulation and analysis is often dominated by researchers from the North. 923

In our support for international research, a "South perspective" is being promoted in terms of the research agenda and in terms of ensuring proper representation from "the South" in decision- making structures. This influences not only the orientation of the research. It contributes as well to situated perspectives on global issues. ${ }^{924}$

As in previous decades, however, thematic support continues to receive a very large part of the budget, and the policies also relatively consistently uphold the importance of both kinds of knowledge: "Problems, such as lack of water or a high infant mortality rate, are linked to various local conditions and must be met with a combination of general and local knowledge."925 Furthermore, Sarec maintained that a trend had started within international organizations in 1990's which implied greater cooperation with low-income countries on agenda setting for example. ${ }^{926}$

In order to achieve "optimum impact", research funding was to be as catalytic as possible, limited in terms of geography or thematic areas, and directed towards areas where Sida and Sweden were seen to have comparative advantage in terms of capacity

\footnotetext{
${ }^{921}$ Sarec $(1998,2000)$. Research Cooperation I. An Outline of Policy, Programmes and Practice, Sida. p14

922 Ibid. pp8-9

923 Ibid. p20

924 Sida-Sarec (2002). Towards Freedom from Poverty. Research Cooperation 2001. p4

925 Sarec $(1998,2000)$. Research Cooperation I. An Outline of Policy, Programmes and Practice, Sida. p9. See also $\mathrm{p} 15$

${ }^{926}$ Sarec $(1998,2000)$. Research Cooperation II. Trends in Development Research, Sida. p27
} 
and resources. ${ }^{927}$ The focus of thematic support was to be guided by a number of criteria and ambitions, for example Sida's action programmes: poverty reduction, sustainable use of natural resources, gender equity, and democracy and human rights. Cooperation with other Sida programmes was desirable where possible, as well as collaboration with other agencies when appropriate. Potential innovation opportunities were also to guide the focus. ${ }^{928}$ Together, all these considerations resulted in a number of thematic priorities:

- Sustainable use of resources (issues like food security, sustainable agriculture, energy technology, environmental economics)

- Health (health systems and health policies, children's health, sexual and reproductive health, HIV/AIDS, tropical diseases and vaccines.

- Technology (biotechnology research capacity, bio-safety, biotechnology policy, support to basic sciences)

- The political, economic and social dimensions of development (changes in political systems, economics, systems for education and research, gender equality). ${ }^{929}$

Multidisciplinary research is also mentioned in this context, as a kind of knowledge that takes research closer to policy relevance. ${ }^{930}$ With the exception of increased focus on biotechnology and associated issues, most of the prioritized areas existed prior to this decade and in that sense do not represent anything new - though they are presented in a slightly different way.

Swedish development research is classified as thematic because it was not by default coupled to bilateral support. Its results, however, could be of interest to low income countries. Two main reasons for supporting Swedish research with development relevance was to ensure that Sweden had - and improved - its development-related research capacity and it also made more universities able to engage in development cooperation projects. ${ }^{931}$

\section{Reducing poverty through sustainable development}

Sarec's policy and methods documents maintained that natural catastrophes, civil wars and environmental destruction added tensions between national and global interests, also affecting aid.932 Global security was a concept that became commonly used within aid circles; it captured the problems of threats to both human welfare and the environment. ${ }^{933}$ At the same time, positive development trends were clear; child mortality rates had halved by 2000 compared to 1960, malnutrition rates were

\footnotetext{
${ }_{927}$ Sarec $(1998,2000)$. Research Cooperation I. An Outline of Policy, Programmes and Practice, Sida.p10

928 Ibid. pp14-15

${ }^{929}$ Ibid. p15

930 Ibid. p15

${ }^{931}$ Ibid. p18

932 Sarec $(1998,2000)$. Research Cooperation II. Trends in Development Research, Sida. p7

933 Ibid. p7
} 
significantly reduced, and primary school enrollment had improved. ${ }^{934}$

The relationship between research capacity and development was framed in relation to sustainable development during the 1990's, and the increased focus on poverty reduction in the 2000's as a Swedish foreign aid goal strengthened this framing. The focus on poverty reduction also sparked a renewed interest the social and economic aspects of sustainable development. The annual report from 2001 maintains that the first decade of Sarec's existence included a more active support of social sciences since it was a way to counteract political oppression in Latin America for instance, whereas the attention in the 1980's and 1990's was more directed towards natural sciences and technology:

Today, countries are expected to formulate and implement strategies for poverty reduction. Economic growth remains an important part of such strategies. However, increasing attention is now being directed to the social context. In order to assess opportunities and develop appropriate strategies, countries must analyse the complex causes and multi-dimensional expressions of poverty. ${ }^{935}$

Social problems are often linked to health and technical issues. Accordingly, social science components are to an ever-increasing degree integrated in projects and programmes that formerly had a tendency to be of an exclusively "technical" nature, such as construction of various forms of infrastructure, agricultural development and health programmes. Sida is consequently stimulating social scientists to cooperate with natural scientists and technicians. ${ }^{936}$

The report talks about the general importance of "critical scientists" for the countries, but the focus on social science is - as illustrated by the quote above - also considered important in light of the demands for Poverty Reduction Papers (PRSPs) by The World Bank and IMF. By 2005, more funds had been provided to subjects like economic planning, democracy and human rights, pedagogy, and gender and demography, mostly within regional and bilateral support. ${ }^{937}$

In this context it is of interest to mention a Sida report from 2003 which dealt with the relationship between environmental problems and poverty. It was a joint publication by Sarec and the environmental policy division intended as a contribution to an evaluation being conducted of the Swedish Foundation for Strategic Environmental Research (MISTRA). The evaluators of MISTRA wanted input on the environmental challenges facing low-income countries in order to make suggestions for MISTRA's future strategies. ${ }^{938}$ The report was critical of a number of things and points out that the way

\footnotetext{
934 Ibid. p8

935 Sida-Sarec (2002). Towards Freedom from Poverty. Research Cooperation 2001. p3

936 Ibid. p24

937 Sida-Sarec (2006). Yearbook 2005. Research Capacity. Towards the Millennium Goals. pp6 \& 33

938 Sida (2003). Environmental Research Challenges in Developing Countries - some reflections. Future Environmental Research, Environment Policy Division and Sarec. foreword
} 
economic factors were allowed priority at the time was not conducive to sustainable development in any way:

Economic incentive structures play a major role in driving environmental change, as individuals (and nations) act in their self-interest with little regard for others or for future generations. [...] There is a complex and mutually reinforcing, two-way relationship between poverty and the environment, sometimes referred to as the poverty-environment nexus. ${ }^{939}$

Poverty and environmental degradation are seen as mutually reinforcing given that environmental problems make livelihood more difficult for people with less resources; every-day challenges of survival are prioritized over long-term issues. Environmental problems are not - and cannot be - the fault or the priority of poor people. ${ }^{940}$ The report takes a critical stance in relation to those who did not recognize the value of nature or those who put too much faith in the power of science:

\begin{abstract}
Ultimately policy is a function of prevailing power structures, norms, values and knowledge. There is often insufficient knowledge of the economic consequences with regard to the environment of a particular set of policies. Frequently there is little understanding of the value of the resilience of biodiversity to human life and processes. There is a common belief that the biosphere is endless, that nature has its own healing mechanisms, and that environmental destruction is not irreversible because science can always fix whatever change is occurring. ${ }^{941}$
\end{abstract}

The global and the local are portrayed as inextricably intertwined, something which is made clearly visible in the case of environmental problems and its unequal effects on already unequal relations. The sociotechnical imaginary this projects is bleak; visualizing science and technology contributing to a strengthening of destructive forces, driving society and the environment in a negative direction. The imaginary was equally bleak a few years earlier, in the policy and methods document, where Sarec stated that "to avoid irreversible global catastrophes," high and low-income countries must "jointly embark on the road to sustainable development" by innovating and reducing consumption. ${ }^{942}$ The environmental problems are in the policies mostly the fault of the high-income countries, but sustainable development is constructed as something only possible if the high and low-income countries join forces.

Among the recommendations for MISTRA's future priorities ${ }^{943}$ was that

\footnotetext{
939 Ibid. pp5-6

${ }_{940}$ Ibid. p8

941 Ibid. p9

${ }_{942}$ Sarec $(1998,2000)$. Research Cooperation II. Trends in Development Research, Sida. p21

${ }^{943}$ Which they suggested should be within the areas of (i) human development needs and ecological system survival, (ii) satisfying future food demand, (iii) sustainable livelihoods in degraded areas, (iv) sustainable management of coastal habitats, (v) energy for sustainable development, (vi) climate change adaptation, (vii) atmospheric haze and development, and (viii) sustainable urbanization.
} 
research should be interdisciplinary given that sustainable development has several dimensions requiring several disciplines (social, economic and environmental). The report also underlined that results should be applicable, and that collaboration with lowincome country researchers and contribution to local capacity building was essential. ${ }^{944}$ Sarec's annual report from 2004 argues along similar lines, natural resources have to be managed sustainably in order for a country to be able to achieve development:

Sustainable use of natural resources is a precondition for economic growth and crucial if developing countries are to escape poverty. It involves innovation, development of new products and adaptation of technologies. Economic policies, institutions and systems that are conducive to growth are also important. However, economic growth does not eradicate poverty by itself but needs to be combined with governmental interventions that allow for a fair distribution of resources and investment in sectors such as health, education and social security systems. ${ }^{945}$

What is interesting to note here is that sustainable development is framed as a prerequisite for economic growth, which in turn can only reduce poverty if measures are taken to ensure equitable distribution of wealth. How these pieces of the puzzle are all seen to fit together, however, is not as consistently portrayed this decade. Both the localist and the universalist discourse are strongly expressed to the point where quite concrete contradictions appear. One such example concerns how economic growth is seen to play into development, something which becomes clearer when one looks at the discussions about innovation.

\section{Imagining research within innovation-systems for development}

The concept of innovation had tagged along since Sarec's beginning, and a "systemsthinking" was not new either in the sense that different actors, policies, institutions and other components and conditions had been envisioned to depend on each other in the national context. In the 2000's, however, the use of "systems of innovation" appeared more consistently, implying something a little different, as illustrated by this quote from the 2004 annual report:

A term that is used diligently is "innovation", in particular in an attempt to intensify cooperation between universities, authorities, politicians and the private sector in order to convert research into practical solutions. One of the challenges for cooperating countries is in building a national capacity to modernise innovation structures and policies. Research councils and universities have central roles, as do the private sector and authorities. ${ }^{946}$

944 Sida (2003). Environmental Research Challenges in Developing Countries - some reflections.

Future Environmental Research, Environment Policy Division and Sarec. p6

945 Sida-Sarec (2005). Research Cooperation 2004. Research Makes Sense. p33

946 Ibid. p40 
It is not clear from the 2004 report where the term is used diligently, but universities are envisioned as important parts of national innovation systems; they produce peerreviewed research results which should then "find their way to applications and users" 947 through cooperation with other actors. A more detailed discussion can be found in a Sida-Sarec report about innovation systems in Latin America ${ }^{948}$ from 2005.

Reference is made to Joseph Schumpeter's ideas from the 1930's and 1940 ' $\mathrm{s}^{949}$ regarding the importance of research and development and entrepreneurship, and the cooperation between firms and organizations in the production of innovations. The report also refers to others who have studied innovation later in the century, such as Christopher Freeman (1987), Carlota Perez (1990), Bengt-Åke Lundvall (1992), Richard Nelson (1993) and Charles Edquist (1997). ${ }^{950}$ The existence of research on the Triple Helix is mentioned (with reference to Etzowitz and Leydesdorff 1995 and 2000) and innovation clusters. ${ }^{951}$ On the basis of these references, the report underscores the importance of supporting knowledge flow between local actors (as well as their connections to important international actors) as a way to support innovation. ${ }^{952}$ The role of innovation in economic development and job creation in industrialized countries is used as an example to follow, and many crucial links between the significant actors were described as missing in low-income countries:

...developing countries do not typically show these characteristics of well integrated local innovation systems. Instead, both essential actors may be missing and in addition essential links between the existing actors could be missing, a condition where the local innovation system can be seen as an "infant local network" (Alänge 1987, pp238-239) ${ }^{953}$

The role of economic growth vacillates a bit, sometimes it is a prerequisite for sustainable development and sometimes it is an effect of sustainable development. Where poverty reduction comes in is not always clear either, the main point is that all of these are seen as interdependent. The parallel increased focus on social sciences seems somewhat separate from discussions about what is important for innovation systems, where the "hard" sciences more often figure:

Engineering sciences, technological skills and analytical capacity are required for direct and indirect ways of combating poverty. It is therefore important for low-

\footnotetext{
947 Ibid. p17. See also pp15 \& 39

${ }_{948}$ A study commissioned by Sarec to assess the use of innovation systems as a concept. ${ }^{949}$ Schumpeter, J. (1934). The Theory of Economic Development, Harvard University Press. and Schumpeter, J. (1942). Capitalism, Socialism and Democracy, George Allen \& Unwin. 950 There are others as well, such as Sverker Alänge and Staffan Jacobsson (1992), Bo Carlsson (1997), Rodrigo Arocena and Judith Sutz (2000), Magnus Holmén (2001), Corona Treviño (2001), Sven Lindmark (2002), and Carlos Aguirre (2003)

951 With reference to Örjan Sölvell et al (2003)

952 Sida (2005). Innovation Systems in Latin America. Examples from Honduras, Nicaragua and Bolivia. p12

953 Ibid. p12
} 
income countries to reinforce their capacity in finding their own niche for product development. Research may lead the way to production suitable for local conditions, as well as for export. A significant extension of the Sida support to strengthening research capacity at three faculties in Eastern and Southern Africa (Makerere University in Uganda, University Eduardo Mondlane in Mozambique and the University of Dar es Salaam in Tanzania) was approved in 2004. This will focus on technology given national priority within the countries, i.e. environmentally friendly technology for sustainable utilisation of natural resources, development of rural and urban infrastructure, renewable energy and energy systems and development of ICT. 954

Innovation systems were also referred to as techno-economic systems in the literature that the Sida-Sarec report from 2005 referred to, something which reflects the centrality of technological sciences as well as the goal of economic growth in the academic history of the framework. Though technologies are considered important in Sarec's policy documents overall, they are also regarded as entailing risks: "as the countries of the South are drawn into the net of a globalized economy, they cannot avoid responding to the promise and threat of borderless Science and Technology".955 Suitable policies are required in order to counteract the uneven distribution of its benefits. New ICTs, biotechnology and new materials technology were technological transformations referred to as significant at the beginning of this decade. It was one of the themes Sarec thought were important to consider when planning future research aid:

They (the technological transformations) have brought about deep changes in the production, distribution and consumption of goods and services, right across the economy and society, with more unforeseeable changes in the offing. They are radically altering the living and working conditions of people in the North and will do so in the South in the not too distant future. [...] Just as the advance of the first industrial revolution two hundred years ago proved unstoppable, the new technology is here to stay, its global march seemingly inexorable. 956

These technologies are in the policy and methods document from 2000 portrayed as creating considerable changes and challenges for society. While the description above might appear slightly technologically deterministic in tone, the discussion continued and deals with issues of how the "South" can meet these challenges and the impact of new technologies through policies and actions. Research capacity building is portrayed as an important readiness, as well as "institutional reforms and innovations, accompanied by the mobilization of indigenous stakeholders for agreed action". ${ }^{957}$ Research on - and

\footnotetext{
954 Sida-Sarec (2005). Research Cooperation 2004. Research Makes Sense. p40 955 Sida-Sarec (2001). Science for Development - Searching for Keys to the Future. Research Cooperation 2000. p27

956 Sarec $(1998,2000)$. Research Cooperation II. Trends in Development Research, Sida. p11 957 Ibid. p11
} 
transfer of - sustainable technologies are also considered an important part of the solution. ${ }^{958}$

Returning to systems of innovation. It would seem from the annual reports that this framework was enthusiastically "rolled out" and received, promising potential leapfrogging effects:

\begin{abstract}
Harnessing innovation to reduce poverty and raise standards of living is the goal of the Innovation Systems and Clusters Programme in Eastern Africa, which aims to fast-track economic development in the region. Supported by Sida, the programme involves the University of Dar es Salaam in Tanzania, Makerere University in Uganda, and Eduardo Mondlane University in Mozambique. The seed of the idea was planted in 2003 and in 2005, with Sida's support, intensive training courses were held in Tanzania and Uganda. The result was 15 pilot projects established in both countries, with first results expected during 2006. Cluster initiatives are organised efforts to increase growth and competitiveness, involving firms, governments and the research community. ${ }^{959}$
\end{abstract}

Innovation is framed as a way to turn research results into concrete poverty reduction action through economic growth. As a result of positive experiences with the African case, Sarec decided to also test working with the framework in Latin America. On the basis of the research discussed in the Sida-Sarec report on innovation systems in Latin America, Sverker Alänge and Sari Scheinberg (the evaluators who conducted the study and wrote the report) set out to examine to which extent universities were entrepreneurial, how the researchers perceived their relation to commercialization of research, whether or not stakeholders in the region collaborated, and how other factors (such as laws, values, customs, history or competence) hindered or enabled innovation activities. ${ }^{960}$ Part of the purpose of the study was to engage the "cooperating countries" in a discussion about innovation systems:

In order to establish a dialogue with cooperating countries concerning innovation, Sida has supported seminars and workshops with researchers, politicians and representatives of the industrial sector in Eastern Africa and in Bolivia, Nicaragua and Honduras. The main purpose of the workshops has been to stimulate awareness, cooperation and debate on the role of clusters in the development of innovations. ${ }^{961}$

There is debate regarding what innovation systems are for. Some researchers maintain that it has leftist origin and aims to adapt to local contexts and can lead to development in a wide sense, while others underline certain kind of technological output and/or

\footnotetext{
${ }^{958}$ Ibid. p23

959 Sida-Sarec (2006). Yearbook 2005. Research Capacity. Towards the Millennium Goals. p31 ${ }^{960}$ Sida (2005). Innovation Systems in Latin America. Examples from Honduras, Nicaragua and Bolivia. p15

961 Sida-Sarec (2005). Research Cooperation 2004. Research Makes Sense. p40
} 
economic aspects, growth, etc. ${ }^{962}$ It is of relevance to ask how Sida and or Sarec understood the concept given that it has several different "schools." In the beginning of the decade this was quite diffuse, but towards the middle and end of the decade innovation systems are more clearly defined as systems to promote both economic growth and poverty reduction. All sciences are seen as important in this system, but technological sciences are somewhat more prioritized.

This conceptualization of innovation systems is an interesting example of how the discourses intertwine and/or clash, depending on how one sees it. One the one hand it is framed as a model that is firmly based on local conditions; "Innovative approaches to capitalize on research findings for economic growth share a common theory but in practice build on local actors and conditions." 963 At the same time, it consistently identifies gaps, and recommends a presumed adequate form for development, telling the low-income countries "how" to develop in some sense. To a certain extent it also prescribes what is reasonable to pursue within this model, all the while singing praise to the importance of local priorities, local context and the situatedness of learning.

\section{The picture of the aid actor: unique, context-sensitive and empancipatory}

In the $1998 / 2000$ policy and methods documents, Sarec's history is discussed in broad terms, telling a story about how priorities went from supporting just international research organizations, to funding national research councils, to focusing on sandwich research training and certain research projects, to research infrastructure and universitywide/institutional support. ${ }^{964}$ The impression one might get is that Sarec's modes of support have developed with time and gotten wiser, so to speak. Another view might be that each decade or mode of support is a product of its time, each with its own strengths and weaknesses. Either way, Sarec reflects upon it history from time to time, and continues to portray itself as different to other donors, as exemplified by the 2000 annual report:

...Sida remains fairly unique in its systematic efforts of supporting research. Representatives of national, regional and international research organisations, invited to examine Sida policies and practices for research cooperation, agreed that conclusions drawn from Sida's experiences could contribute to shaping new commitments for research in development cooperation at large. ${ }^{965}$

\footnotetext{
962 See for example Benner, M. (2008). Kunskapsnation i kris. Politik, pengar och makt i svensk forskning, Nya Doxa. pp39-41 and Eklund, M. (2007). Adoption of the Innovation System Concept in Sweden, Uppsala University. pp42-43

963 Sida (2005). Innovation Systems in Latin America. Examples from Honduras, Nicaragua and Bolivia. p5

964 Sarec $(1998,2000)$. Research Cooperation I. An Outline of Policy, Programmes and Practice, Sida. pp28-30

965 Sida-Sarec (2001). Science for Development - Searching for Keys to the Future. Research Cooperation 2000. p3
} 
Unlike traditional research funding, Sida chooses to strengthen research capacity at the institutional level, rather than limiting support to research projects or research training of individuals. 966

Sarec upheld the importance of basing support on low-income country priorities and not on pre-defined research agendas. ${ }^{967}$ Certain thematic priorities are deemed relevant, but creating capacity is consistently lifted as the most central issue. They are critical of the dominance of externally proposed research cooperation in aid. ${ }^{968}$

Sarec is portrayed as an empancipatory actor in its critique of privatizing trends within research. In relation to the development of biotechnology, the 1998 annual report stated:

More than $70 \%$ of the poor in developing countries live in rural, marginally productive areas largely untouched by modern technology. They depend for their livelihoods on indigenous genetic resources, developed and nurtured for hundreds of years. However, in recent decades, a shift has taken place concerning the ownership of the world's genetic inheritance. The private sector has been increasingly able to reap the benefits of agricultural research on plant improvement. Genetic resources are no longer considered the common heritage of humanity. ${ }^{969}$

Similar criticism is delivered in relation to health research and the role of profit making industries. Tropical disease is not a lucrative business, which is highly problematic given that so many people in the world suffer from these non-lucrative diseases. ${ }^{970}$ Sarec maintains that support to CGIAR and WHO is one way to highlight these problems. Support to an African regional network on biotechnology issues was another. Despite the quite broad approach to capacity building that Sarec had, and the emphasis on local or national priorities, the annual reports sometimes frame the results of the support in a much more "globally oriented" manner. In the annual report from 2005, countries that had received Sarec support were said to have gained increased ability to:

- Exploit natural resources to further the country's economy

- Develop society in a way that is consistent with the principles of sustainable development

- Choose technologies that attract foreign direct investments

- Negotiate on the international arena ${ }^{971}$

\footnotetext{
966 Sida-Sarec (2006). Yearbook 2005. Research Capacity. Towards the Millennium Goals. p8 967 See also Sarec $(1998,2000)$. Research Cooperation I. An Outline of Policy, Programmes and Practice, Sida. pp26-27

${ }^{968}$ See for example Sida-Sarec (2006). Yearbook 2005. Research Capacity. Towards the Millennium Goals. p11

${ }^{969}$ Sida-Sarec (1999). A Sea of Opportunities. Research Cooperation 1998. p3

970 Ibid.

${ }^{971}$ Sida-Sarec (2006). Yearbook 2005. Research Capacity. Towards the Millennium Goals. p8
} 
The increased abilities above can be seen as quite a strong expression of the universalistic discourse given that they are all oriented towards ideas and issues that are thought to ring true for all countries. It is assumed that foreign direct investments are the goal when choosing technologies, for example. Exploiting natural resources for economic growth could be considered an somewhat odd description of an ability to have gained in light of the ability that follows underneath - to develop society sustainably. In relation to the marriage of discourses this decade, however, it is not surprising. The principle of sustainable development is an expression of both the universalist and the localist discourse.

\title{
Sarec within Sida. Embracing change while resolutely defending boundaries between science and politics
}

The "special case of research" (forskningens särart) is a recurring theme in both the documents and the interviews concerning this decade. The differences between research aid and other aid (Sarec and Sida) was an issue since the start of Sarec, but it becomes extra pronounced during the 1990's and 2000's, after the fusion.

Sarec remained much the same in its organizational form, and research retained a separate budget though part of the funds were managed at other parts of Sida (parts of the thematic support for example). Sarec's staff remained in one place up until 2008. The merger with Sida is described in the annual reports and methods documents as having had positive effects, but there are comments marking the difference between aid to research and other aid:

\begin{abstract}
The new opportunities for coordination within Sida have many promising features. However, the balance is fine between supporting research as a long-term investment and supporting research of more immediately applicable use. Research cooperation should not be transformed into a short-term supportive instrument at the expense of building a national basis for research in partner countries. Such immediate research needs should continue to be met within various sector contributions in the future. ${ }^{972}$
\end{abstract}

The former directors I interviewed were all critical to the fusion. Some of them felt more strongly than others, but it was clear that they thought that Sarec would have been able to do a better job if it had remained a free-standing agency. One idea was that the credibility of the agency in the eyes of Swedish universities as well as universities in lowincome countries was greater when Sarec was independent. The long-term and scientific goals did not have to compete in with Sida's shorter and more political commitments. The directors uphold the boundary between politics and science in this respect. An example of this is when Olsson discusses a clash of priorities between Sida and Sarec concerning investments in the area of health sciences in Tanzania:

972 Sarec $(1998,2000)$. Research Cooperation I. An Outline of Policy, Programmes and Practice, Sida. p34 
Another example is Tanzania, where a lot of good research, staff development and other things were taking place. They had made some interesting discoveries within their HIV-research - research which was of relatively significant size at their medical faculty. A colleague at Sida said that since they had pulled out of supporting the health sector in Tanzania, why should Sarec continue to support health research? That view considers Sarec's support like a re-enforcing appendage to aid, while my view is that we are supporting the development of a research university in Tanzania. [...] and you cannot just switch areas of support like that after two years. 973

Olsson maintained that they had to fight to keep Sarec's separate budget intact during her time as director. Her impression was that within Sida at large, the long term role of research was less well understood and the Sarec staff felt that only immediate needs would be given priority if research funds were not protected. ${ }^{974}$ This is illustrative of the continuous tension between research as a special kind of aid versus research as a part of other aid. Research aid is associated with scientific values first and foremost, and longterm commitment - juxtaposed to Sida's general aid, portrayed as more politically determined and short-term. Though both types of aid worked with the method capacity building, for example, there were different time horizons and ways of working. Kjellqvist claims that this division is based on the same arguments as when the parliament was to decide about Sarec's instatement in 1975 (concerning the independent existence of Sarec). ${ }^{975}$

\section{Evaluated at 30 years}

Six evaluations were conducted of Sarec's work and published in 2006 focusing on bilateral cooperation, international and thematic programs, Swedish development research and Sarec's internal organization. ${ }^{976}$ Sida also published a synthesis report summarizing the findings of all of the reports. ${ }^{977}$ The studies focused on goal fulfilment, efficiency and relevance of Sarec's policy and activities. There were both positive and

\footnotetext{
973 Transcription (2009). Interview with Berit Olsson 092509. pp8-9

974 Ibid.

975 Kjellqvist, T. (2013). Biståndspolitikens motsägelser om kunskap och tekniköverföring - från konkret praktik till abstrakt policy. doctoral dissertation series, Blekinge Institute of Technology. pp178-179

976 Greenberg, A. and A. Muchanga (2006). Evaluation of Sida Information and Communications Technology Support to Universities. Sida Evaluation 06/13., Boeren, A., T. Alberts, et al. (2006). Sida/SAREC Bilateral Research Cooperation: Lessons Learned. Sida Evaluation 06/17., Lenefors, L., L. Gustafsson, et al. (2006). Sida Evaluation 06/22, Organisationsstudie av SAREC., Edqvist, 0. (2006). Sidas U-landsforskningsråd. Deiaco, E., A. Högberg, et al. (2006). SARECs stöd till svensk u-landsforskning., Rath, A., G. Björklund, et al. (2006). SAREC Support to International and Regional Thematic Research Programs 2000-2005. Individual reports and cases. and Rath, A., G. Björklund, et al. (2006). SAREC Support to International and Regional Thematic Research Programs 2000-2005. Main report. 977 Eduards, K. (2006). Review of Sida's Research Cooperation. Synthesis Report.
} 
critical conclusions, all of which also reflect certain views of the role of research in development. Some of the conclusions are summarized below:

\section{Positive aspects:}

- The long-term form of support.

- Sida-Sarec is one of the few donors who support basic sciences, which is necessary in order to be able to conduct applied research.

- The fact that it is demand-driven. Transferring of responsibilities to the LIC is positive, adapted to their administration etc.

- The systemic approach to capacity building.

- Interdisciplinary research is being stimulated, something which is thought to increase relevance and applicability.

- It is a positive trend that LIC universities can look for suitable research and training partners in the region when it is a better option.

- The staff at Sarec, committed and flexible. Joint learning approach.

- The links to national policies and Swedish development objectives.

- Sida has the possibility to be "lead agency" the area of research. Research should be a high profile area in Swedish aid.

\section{Critique and other recommendations for improvements}

- Overall objective with aid not easily combined with goals of research. Different cultures. The merger 1995 brought together organizations, not programmes.

- More university-industry/other society stakeholders cooperation would be positive. More "real-life activity". More priority to projects that directly or indirectly improve the conditions of the poor and promote equitable economic growth

- The connection between research and higher education could be stronger

- Links to other Sida programs, embassies and other donors are weak. Greater synergies could be achieved. Research as an area of aid crucial to sustainable development should be emphasized.

- Sustainability of various projects should be included in the planning phase so that universities more quickly start applying for other types of funding than that of Sarec.

- When local project selection processes are weak - Sarec and Northern reviewers dominate the approval processes.

- The fact that research aid has goals tied to both research and aid makes it more difficult to follow up - not least quantitatively. A clear, relevant and useful monitoring and evaluation framework is needed.

- There is an implicit principle that cooperation between universities should preferable take place with Swedish universities - something which interferes with the demanddrivenness of the programme.

- The long-term commitment is essential because research capacity is complex and takes time. However it can also lead to projects that are forever donor-dependent.

- The Policy for Global Development has not had much effect on Swedish research funding. Sida has gotten involuntary monopoly on Swedish development-related 
research. Funding of such research should be increased, but through the cooperation with other research councils. ${ }^{978}$

Several of the evaluations included in their main recommendations that research aid could or should have more short-term effects and be more closely tied to other aid, while others support the distinction between research aid and other aid:

There is the need to begin focusing on the broader question of "systems of innovation" at the national level, which take into account the use of research results and complementary inputs. ${ }^{979}$

There is a need to maintain the distinctiveness of Sida/SAREC:s domain of work, with a clear distinction from regular Sida programs (as a Research Committee member put it, "SAREC is a part of Sida, but also apart from Sida"). In general, support for research and higher education should not be confused with many wideranging development cooperation efforts because it has longer time horizons, involves different stakeholders, and requires different mindsets, experience, and expertise. ${ }^{980}$

In Sida's response to the evaluations, ${ }^{981}$ they agreed that the results of support to research should be applied in poverty reduction efforts but they also uphold the need to see research aid in two time-frames, one short-term and one long-term. Otherwise, the available research capacity risks being absorbed by consulting tasks and other investigations for example.982 Regarding innovation systems as a tool to increase applicability, Sida maintains that they had started cooperation with The Swedish Innovation Agency (VINNOVA) in order to promote the use of innovation systems in low income countries. ${ }^{983}$ Sarec was portrayed as a successful international agency, its positive

978 Rath, A., G. Björklund, et al. (2006). SAREC Support to International and Regional Thematic Research Programs 2000-2005. Main report., Deiaco, E., A. Högberg, et al. (2006). SARECs stöd till svensk u-landsforskning., Boeren, A., T. Alberts, et al. (2006). Sida/SAREC Bilateral Research Cooperation: Lessons Learned. Sida Evaluation 06/17., Edqvist, O. (2006). Sidas Ulandsforskningsråd., Lenefors, L., L. Gustafsson, et al. (2006). Sida Evaluation 06/22, Organisationsstudie av SAREC., Eduards, K. (2006). Review of Sida's Research Cooperation. Synthesis Report. and Schedvin, T. (2006). Översyn av verksamhetsgrenen forskning: sammanställning av rekommendationer, Sida. Sida-Sarec (2006). Letter to the Swedish Ministry of Foreign Affairs. Summary and comments regarding the evaluations published in 2006. 979 Rath, A., G. Björklund, et al. (2006). SAREC Support to International and Regional Thematic Research Programs 2000-2005. Main report., p50

980 Ibid. p9

981 Prepared in late 2006 by director general of Sida Maria Norrfalk and advisor Anders Berlin after consultation with evaluators True Schedvin and Ulla Andrén, and unit managers Berit Olsson and Eva Lithman.

${ }^{982}$ Sida-Sarec (2006). Letter to the Swedish Ministry of Foreign Affairs. Summary and comments regarding the evaluations published in 2006. p6

983 Ibid. p8 
impacts and uniqueness was underscored by several evaluators. ${ }^{984}$ In their response, Sida agreed that research should become a high profile area and further ideas about how to achieve this would be presented budget proposition for 2008.985

In summary, the 2006 evaluations had an array of suggestions for improvements, but in general they were all supportive of Sarec continuing its operations. Sida expressed support for most of the conclusions, with some modifications.

\title{
The disbanding of Sarec
}

In 2008, the politics governing Swedish aid were reformed, resulting in among other things far fewer collaborating countries and revised foreign aid goals. Some key words used by foreign aid minister Gunilla Carlsson in the information about changes to come within Swedish aid were efficiency and comparative advantage ("Sweden cannot do everything everywhere"). ${ }^{986}$ Similar to the fusion of Sida, Sarec, BITS and SwedeCorp in 1995, this reorganization was preceded by a change in government.

Sida was reorganized completely in 2008, and Sarec along with it. According to former director Kjellqvist (2008-2010), among others, the evaluations of Sarec had little to do with the disbanding of Sarec since the recommendations overall were supportive of continued activities by Sarec:

No relation whatsoever. The reorganization did not in any way consider what research cooperation was, the purpose was solely to steer everything in the same way, in a streamlined organization...[...] Research cooperation is not the only area that is different, everything is. If you try to mold a diverse set of operations like foreign aid into one form, it will fail.987

Former director Carlman's view was that research aid (in the form it was organized under Sarec) was the victim of a series of reorganizations:

\begin{abstract}
Nobody was really ever out to get Sarec, research just became some sort of innocent bystander... it started with the budget being divided, and then the organization was divided. Then came the reduction where several subject specialists were let go [...] So the sum of it all is that research aid today is significantly reduced in its capacity, and this is very unfortunate since it has never been the subject of a specific decision, it is the result of organizational changes $[\ldots]^{988}$
\end{abstract}

\footnotetext{
984 See for example Boeren, A., T. Alberts, et al. (2006). Sida/SAREC Bilateral Research Cooperation: Lessons Learned. Sida Evaluation 06/17. p5 and Rath, A., G. Björklund, et al. (2006). SAREC Support to International and Regional Thematic Research Programs 2000-2005. Main report. $\mathrm{p} 5$

985 Sida-Sarec (2006). Letter to the Swedish Ministry of Foreign Affairs. Summary and comments regarding the evaluations published in 2006. pp8-9

986 Carlsson, G. (2007). The New Development Cooperation (ppt), The Prime Minster's Office and the Ministry of Foreign Affairs.

987 Transcription (2010). Interview with Tomas Kjellqvist 100110. p4

988 Transcription (2013). Interview with Rolf Carlman 032013. p5
} 
Carlman elaborated on the side effects of the smaller organizational changes at Sida a bit more. One effect of splitting parts of the research budget was that Sarec could no longer as easily coordinate the different levels of support (international, regional and bilateral). This weakening of control, he said, was later exacerbated by the movement of staff to other parts of Sida. These types of changes, maintained Carlman, affected many aid areas though, not just research. 989

Olsson did not say much about the reasons for the disbanding since it was a relatively recent development at the time when I interviewed her (2009), but she talked about the same step-by-step reduction of control caused by different organizational logics that Carlman mentioned. She also raised the increased focus on producing short-term results as issues that reduced the strength of Sarec. ${ }^{990}$ Olsson maintained that it was a bad idea to reduce the capacity within research aid, not only because of the amount of good work that has been enabled in low-income countries, but for Sweden's image:

\begin{abstract}
Research aid gives Sweden a good name. Sweden as a Nobel Prize country, Sweden as a knowledge economy [...] it is hard to explain to the surrounding world why we should reduce support for research. I am biased, but I think it is a bad idea to remove the Sarec name. It is well-known and has a good reputation. Of course there are things that could be changed but it is fairly established and respected activity. ${ }^{991}$
\end{abstract}

Whether or not anyone was purposely "out to get" Sarec in the process of reform that followed the government change in 2006 is not something that can be answered here. What is clear, however, from both the documents and interviews, is that there had always been a kind of wall between Sarec and Sida - between research aid and other aid.

\title{
Concluding discussion
}

This decade, the rhetoric surrounding local priorities was intensified at the same time as global issues were more frequently discussed. The dominating sociotechnical imaginary was a future with knowledge societies that enable locally relevant sustainable development. Economic growth and poverty reduction are possible through innovations based on both international and national research. The role of research aid in this was to contribute to capacitating these universities and assisting in the connections with surrounding society actors. Research aid also assisted in the development of relevant knowledge, networks and capacity through support of international and regional research organizations.

Part of the reason why national systems of innovation gained influence was a rejection of neoclassical economics and its conceptualization of the role of technology in development. Innovation systems is a dynamic view, underlining things like the need for the cooperation of many different actors, different kinds of knowledge and the specificities of context. Perhaps it is an attractive combination because it would seem to

\footnotetext{
989 Ibid. pp3 \&5

${ }_{990}$ Transcription (2009). Interview with Berit Olsson 092509. p20

991 Ibid. p17
} 
fit anywhere in its adaptability. One might pose the question, however, why the innovation system model should be considered any different than other grand theories of development, why should it be promoted in all low-income countries? At the same time, if it is perceived to work well by those involved, why not? The question of whether or not is appropriate needs to be answered by those affected by it.

In contrast, the directors did not talk much about innovation or economic growth; they underlined the importance of research capacity as crucial for independent problem-solving and higher quality in university education first and foremost. Development research was considered important but secondary, and the relationship to poverty reduction and economic growth was regarded as being necessarily indirect and long-term, and efforts to make the effects more short-term risked being at the expense of building research capacity. The directors, too, share the fundamental belief in modern science - but would appear to express the localist discourse somewhat more strongly than the universalist one. I say this because they consistently attach value to supporting all kinds of sciences - a broad approach to building capacity is seen as more important than producing research results within specific pre-determined areas.

The boundary organization's context within a larger organization placed new demands on Sarec, adding new routines and structures. Did the wall between research and other aid lead to the disbanding of Sarec? This would entail that Sarec failed in fulfilling its role as boundary organization in relation to the political principals. Another interpretation is that with the strong entrance of innovation systems thinking in aid, scientific knowledge was one of several important knowledges. This would in effect remove some of the "specialness" of research aid and according to this logic, increased mainstreaming into other aid would make sense. 


\section{Concluding discussion: the boundary organization's conundrum}

Foreign aid is a contentious area of politics, full of opinions, perspectives and clashes in the struggle to define futures, "a dramatic and complex struggle" as Nederveen Pieterse states. ${ }^{992}$ Add research politics to that and imagine an organization trying to navigate the resulting vast and diverse ideational ocean and fulfil the goals of both political principals and scientific agents. This diversity and the struggles it may entail could be seen as a good thing in that it implies a sort of constant negotiation, ${ }^{993}$ but these negotiations also involve many tensions. Though some things do not seem to change significantly in Sarec's policies, such as the overall task of the organization, there have been several discontinuities and interesting breaks in how the policies envision the road to the goal. A good way to start a concluding discussion may be to return to the beginning and have another look at one of the quotes from Sarec's first annual report:

Those who are themselves involved in research tend to emphasize the free, unplannable and innovative aspects and to stress the long-term usefulness of the research activity, while those who are not themselves engaged in research often put the emphasis on the goals, steering, planning and more immediately useful aspects of the same process. ${ }^{994}$

The quote illustrates what I in chapter 5 called "the boundary organization's conundrum." It raises many interesting questions and illustrates that the combination of research and foreign aid politics can be problematic, foreign aid and research have different modus operandi, and are somewhat at odds with one other when it comes to the goals and definitions of capacity building for example. What kind of capacity should be built, why, where and how long should it take? Is it local individual capacity, institutional capacity or both? Is the purpose to contribute to development over a longer time period, or are general, internationally valid research results more important? How are these different capacities and results measured and evaluated?

In order to briefly recap what this study has found, I return to my theoretical framework, a framework which has followed along the chapters in a subtle manner, underpinning my analysis.

\footnotetext{
992 Nederveen-Pieterse, J. (2010). Development Theory (2nd ed), Sage Publications. p xviii

${ }_{993}$ In line with the reasoning of ibid.

${ }^{994}$ Sarec (1977). Sarec's First Year, Annual Report 1975/1976. p10
} 


\section{Four decades of science aid. Negotiating capacities and imagining research for development}

Returning to Jasanoff and Kim's question: Why do states support science? And why do states support science in low-income countries? A short answer might be; because of both solidarity and self-interest. The main purpose of this study has been to contribute to an understanding of how research policy discourse in the context of foreign aid has developed in the last few decades. I have focused on the case of Sarec due its pioneer status and because its existence is an expression of how the Swedish state has supported science for development. Through framing research aid discursively, I have explored how the role of research for development has been constructed in official Sarec texts and through the perspectives of former directors. What roles do the universities and individual researchers have, and how does the aid actor fit into the equation? I have sought to identify some of the dominant sociotechnical imaginaries and how they envision science and technology in future societies.

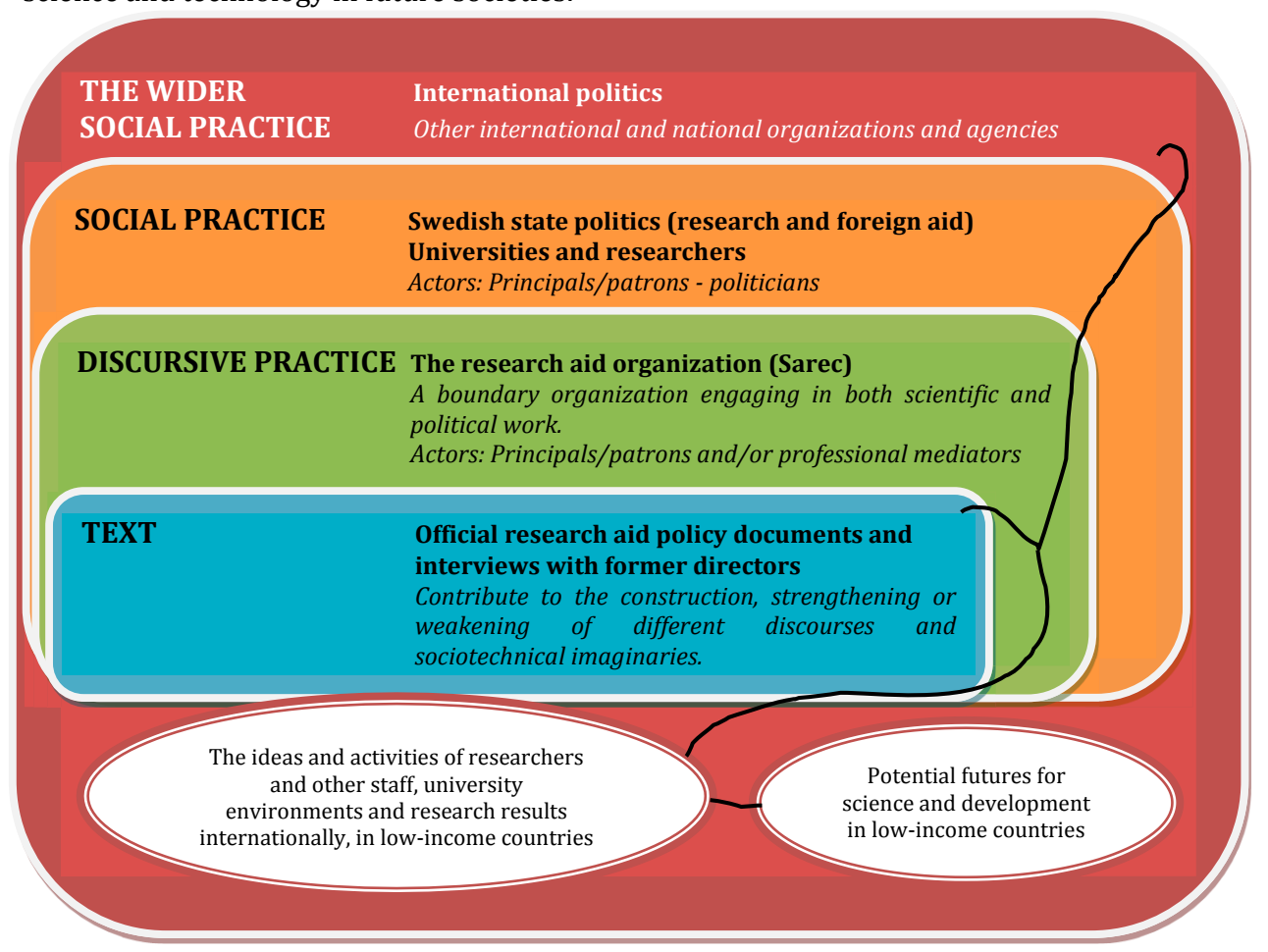

Figure 10: Theoretical framework

In relation to the figure above, my attention has been primarily directed towards the level of text and secondly towards the social practice and wider social practice. The discursive 
practice has also been accounted for, but to a much lesser degree; I have not aimed at capturing a complete picture of the organizational dynamics.

The decades studied have framed the questions above in slightly different manners, different discourses have struggled and sociotechnical imaginaries have varied, but I would say that the essential boundary organization conundrum and its capacity building negotiations have remained central. I chose to analyze the policy development through identifying and following discourses and their central objects - the two most central ones being the universalist and localist. These discourses are an intentional simplification; intertwinings, complexities and dependencies between them are both expected and recognized. The discourses represent an ideational heritage of sorts, which keeps being reflected, reinterpreted and renegotiated with time and new influences.

To recap, I maintain that the two discourses share the starting point that modern science can contribute to development and that local/national research capacity is important for the production and/or use of research results. The discourses differ in how they define or relate to a number of central objects, namely: the meaning of development, the kind of research considered most relevant for development, the role of high-income country and aid actors, and the views of how to best build capacity. Sarec's localist research for development discourse originated in Marxist and dependency theory ideals and can in later decades be associated with ideas from human development and post-development for example. The universalist discourse originates in ideas about modernization and linear progress, and is later fuelled by neoclassical economics and neoliberal ideology for instance. ${ }^{995}$ I would say that these two discourses reflect the different views of knowledge and development during the decades in question. This does not mean that Sarec explicitly adhered or opposed itself to all of the theories listed above. Sometimes the references were explicit, as I have shown, to dependency theory, neoclassical economics and systems of innovation for instance. Other times there are no specific associations or references, but lines of argument could be identified as compatible with certain views. My aim has not been to prove that Sarec adhered to this or that theory. Instead, I have illustrated the diversity in relatively general terms, the sometimes contradictory standpoints; both the continuities and discontinuities.

While keeping in mind that neither discourse operates alone, it is of interest to explore what consequences and implications the different ideas might have. If one has as point of departure the idea that science is universal, then research aid might appear less problematic than if one sees science alongside other systems of knowledge and knowing for example. The latter would imply that support has to be tailored considering many more contextual factors, and using Western science as a such a clear model would not be a given. How one defines the "problem" has consequences for what kind of "solution" is identified. It also affects which sociotechnical imaginaries gain ground. Which types of sciences and technologies are considered essential for future developments? Sometimes information and communication technologies are heralded as key for all development, sometimes health research or agricultural research. These

995 See the tables in chapter one of this book for an overview of development theories, pp28-31 
priorities may be short-lived or hang around for a long time, but they imply that certain research is especially crucial for the future, while others are not.

The policy of the early years was characterized by a strong critique of modern science associated with this discourse. There was also a clear belief in the potential of scientific research to enable development. Contributing to local capacity was expressed as the kind of support that should be dominant, but the "inherited" support to international organization research remained the largest budget post as Sarec worked to find its "place" and modes of work. The aid actor role was regarded with some unease in the first years' documents; avoiding dependence was an active topic of discussion which meant for example that short-term projects were considered preferable to long-term ones. The aid actor was framed as a catalyst which should preferably not remain involved for too long. Assisting in increasing the number of scientists in low-income countries was seen as a good way to contribute to the building of local research capacity. These scientists would then presumably study issues of development relevance and be able to make use of internationally available knowledge as well. Experimental collaboration with research council structures was also undertaken. The first years included expressions of both the universalist and localist discourses, though the localist perspective was more prominent in the critique of colonialism and dependencies for example. The universalist discourse was in support of the production of general knowledge and imagined the future of research in low-income countries to be very similar to the high-income country research system. The dominating sociotechnical imaginary was, nevertheless, low-income countries with independent capacity to solve their own problems.

The self-critique was toned down considerably during the 1980's, and the universalist discourse was strengthened through an emphasis on applicability and more pragmatic views of research for development. Natural, technological and health sciences were developed to a greater degree than during the 1970's. The universalist discourse was supportive of the idea of "filling gaps" in order to mould the low-income country research systems to match "Western" ones; constructing research councils from scratch for instance. The localist discourse is expressed through strong criticism of international organization research as it was organized at the time, as well as the emphasis on capacity building based on what was already there. Strong belief in the need and use for general knowledge persisted, however, and there was greater emphasis on "global" priorities for research. The sociotechnical imaginary most common in the 1980's documents was quite pragmatic. It was one where the universities in low-income countries have enough researchers to conduct development relevant research in a wide variety of areas, teach students and make used of international collaboration to solve local problems. Researchers would also help to ensure that the countries' resources are used efficiently.

Throughout the 1970's and 1980's, scientific knowledge was largely considered a public good, but during the 1990's, the commercialization of scientific knowledge started to increase. Swedish interests (mutual interests) and "comparative advantage" were further highlighted more towards the end of the 1990's as well as in the 2000 's, but the policy of the 1990's was characterized by a critical revival of sorts. Emancipatory ambitions and concern for grim futures with environmental deterioration 
dominated the sociotechnical imaginaries of the early 1990's. Sustainable development becomes a key concept through which Sarec's task is interpreted, and the two discourses become more pronounced and closely aligned; a localist universalism one might call it. Problems are considered global and local contexts are seen as unique, yet solutions are to some extent universal. The future universities needed to be strong in order to handle the many challenges posed by new technologies, economic globalization and environmental deterioration. Cross-disciplinary and applied research were central in this imaginary.

The intertwining of the discourses continued during the first decade of the 2000's; the localist anti-colonial critique remains present, but firmly coupled to universalist ideas about global priorities and quite clear ideas about what a university should be. Universities in low-income countries were at the centre of many expectations, and increasingly so after the entrance of the knowledge society discourse. Despite the fact that the conditions often were quite different to high-income countries (demands on higher education not the least), universities were portrayed as hubs for national innovation systems as well as facilitators of poverty reduction. They were expected to do the same as universities in high income countries, and more. It was assumed that science could be harnessed and steered to benefit national goals, at the same time as it was conceived of as a highly international endeavour. Economic growth becomes more central.

\section{Universalist localism}

Development focuses on the present and the Development is conditioned by history. Multiple future. Economic growth is central. factors important.

The interests and priorities of HIC actors The interests and priorities of LIC actors dominate dominate

HIC actors as experts and catalysts. Not HIC actors as temporary facilitators. Critical of critical of aid actor role. aid actor role.

Universal knowledge and technology. Local production and development of

Results in focus. Technology transfer. knowledge and technology. Process in focus. Absorptive capacity. Indigenous capacity.

System important, but single factors are Many factors important, the system very significant.

Disciplinary research seen as superior. Cross-disciplinary research highly valued. All Some research less value-laden than others. research is value-laden.

Neoclassical economics, modernization, Dependency theory, world systems theory, neoliberal values human development, post-development

Modern Western science as model for development Local/national research capacity is necessary

Table 6: The discourses II 
This merger of the localist and universalist discourses is exemplified by the increased use of systems of innovation and the emphasis on global priorities like the Millennium Development Goals; both of which have explicit ties to local contexts and their specific preconditions. Overall, Sarec's policies paid attention to the uniqueness of context and the priorities of local actors at the same time as they were concerned with filling gaps and producing general knowledge. This also seems to be in line with what Nederveen Pieterse illustrates; development paradigms have in certain respects converged. ${ }^{996}$

The fact that the two discourses seem to intertwine does not remove the tensions between some of these different views and standpoints. While the diversity in the policies can be considered a sign of productive negotiations, shedding light on the historical trends and tensions can be useful for a discussion on present and future policy. It is important to be aware of the imaginaries being pursued in order to counteract science being indirectly used to legitimate academic neo-colonialism.

\section{The special case of research aid}

In the 1992 evaluation on bilateral cooperation, Widstrand and Valdelin stated "Sida is Sida and Sarec is Sarec and the twain shall never meet,"997 illustrating the fact that research aid has been a special case in several ways. The task of research aid has clearly entailed strenuous boundary-balancing in order to fulfil its objectives in relation to both its main political principals (consisting of the Ministry of Foreign Affairs, the Ministry of Education and Research, and the Swedish Government and Parliament). I have not investigated the political principals in this case, their roles are black-boxed in that sense. The fact remains, however, that the government, the parliament and the two ministries are responsible for producing the general policies and goals that agencies like Sida and Sarec have to adhere to.

The figure below aims to illustrate that research aid entails handling political and scientific influences from several directions. If one were to be interested in exploring the organizational dynamics in more details, the relationship between the political principals would be of interest to investigate further. The relationship between the scientific agents and Sarec is of course another very interesting area to look into, in relation to how the explicit political intentions of research aid get translated on its way between actors.

\footnotetext{
${ }^{996}$ Nederveen-Pieterse, J. (2010). Development Theory (2nd ed), Sage Publications. p182 997 Widstrand, C. and J. Valdelin (1990). An Evaluation of the Bilateral Institutional Research Cooperation supported by Sarec. p27
} 


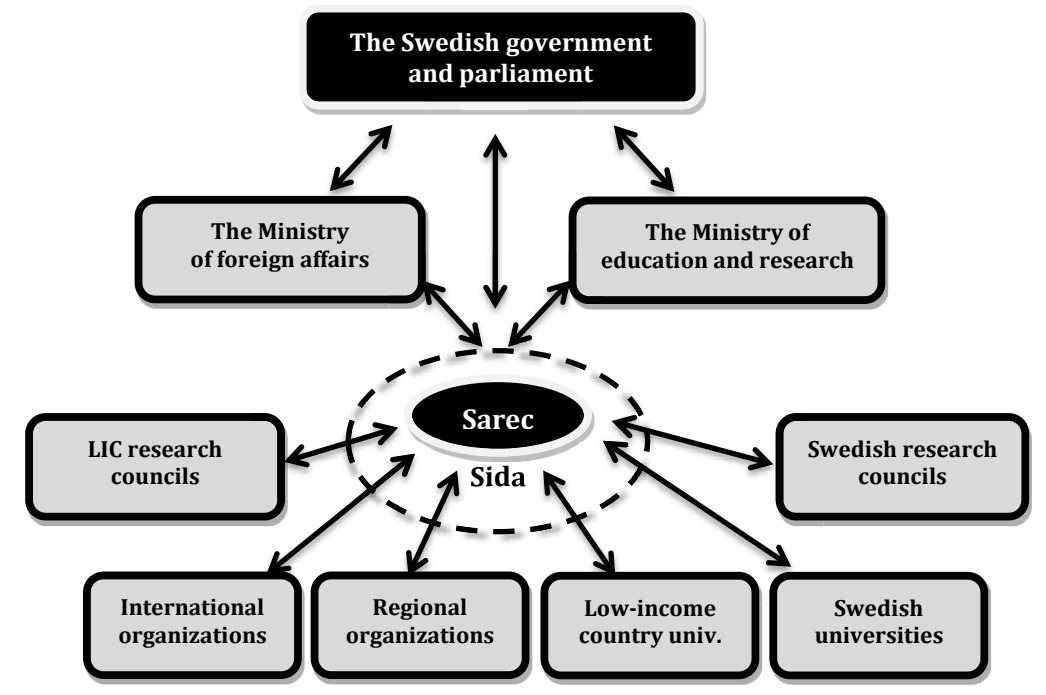

Figure 11: The boundary organization

More arrows could be drawn, and there are other actors, but suffice it to say that there are many organizations, policies and people involved in imagining and doing research for development.

It seems like Swedish research aid policy in the period studied was consistently both innovative and mainstream when compared to its principals research and aid politics. Sarec was a pioneer in the work with local capacity building through bilateral cooperation before the concept of capacity building was taken up by development organizations in general. Sarec also talked about innovations and conceptualized universities as a part of a bigger knowledge system before the knowledge society and innovation system buzz started. They talked about situated researchers and the context dependence of technology in the 1970's. They criticized Swedish university research priorities and advocated cross-disciplinary research at times when others did not. At the same time, Sarec's support to building research capacity also to some extent seemed to mirror mainstream conceptions of the role of science dominating at the time in relation to prioritized research areas for example.

A very prominent theme in the interviews was that Sarec was constructed as a scientific organization above all, and research aid as something which in fact was not compatible with other aid; other aid is considered much more political. Sarec first and foremost supported long-term capacity building through cooperation based on independent scientifically objective principles. The former directors consistently point out the difference between scientific evaluation of efforts and political decisions about what to do. In politics, decisions made are not built on as solid bases as science.

Starting out in a research policy climate that invested in sector science, it is perhaps not surprising that development-related research at Swedish universities has 
come to be funded mostly by Sarec, and not other research councils. Swedish research bills have relatively consistently marginalized development research. Developmentrelevant research has been considered less excellent than other research in a national perspective. Research cooperation with high- and middle income countries has in research bills been framed as more desirable and productive than cooperation with lowincome countries. It remains to be seen what the recent move of u-forsk (the research council function of Sida) to the Swedish Science Council entails in relation to the status of development research.

Since I have not studied research aid in practice I cannot say more than the evaluations say about the diversity of results of projects and cooperation in different countries. The same goes for how the low-income country actors perceive Sarec's policies and ways of working. I can, however, draw some conclusions in relation to previous research. Both researchers and policymakers claim that linear and stage-based development theories have been replaced by more dynamic and system-oriented views, yet the idea that the Western model of science and technology is the way forward is not often questioned. One could argue that this might instead enforce the "old" linear ideas, reducing the amount of futures that can be envisioned instead of embracing some sort of diversity. The consequence of this may be that inequalities continue to widen.

The tensions of the different boundaries is consistently present. The mix of sometimes incompatible perspectives could be considered problematic, but they could just as well be seen as creating a productive debate since it shows that new perspectives keep getting thrown in the mix. It becomes evident that Sida, other aid actors and the EU, had slightly different ideas about how and why to build capacity for example. One might pose the question whether too many new perspectives might have rocked the foundations after the fusion with Sida. The knowledge society discourse and innovation systems framework reconfigured research as part of larger system of knowledge, perhaps partly removing some of its status as "special case" within Swedish aid.

Using a systems of innovation approach or Mode 2 science in capacity building is by some of the previous research framed as an effective way to support development relevant application. In Sarec's policies, innovative knowledge societies seem to be the dominant sociotechnical imaginary during the 2000's. It seems to capture, at least in theory, all the different dimensions of knowledge production and capacity development that research aid has aimed to support. There is also plenty of critique of such models, not least from science policy researchers.

King and McGrath suggest that he trends from the late 1990's and early 2000 's reflect an attempt to more explicitly than before marry globalization with poverty reduction and solidarity with self-interest. I concluded from my review of the literature on research aid that Sarec's mode of work tends to be characterized as systemic and emancipatory to a greater degree than it is considered linear and neocolonial. These results are mainly coupled with the 1990's and 2000's (like King and McGrath's study 
referred to above), the modes of support of the 1970's and 1980's are by some considered to have been less emancipatory. ${ }^{998}$

The practice on the ground is likely to be quite diverse, as was illustrated by Velho's critique concerning research aid to Nicaragua for instance. The practical everyday implementation of research aid surely differs depending on country, time period and the people involved. Since this is focused on the policies, however, I would like to make the point that though the fervour with which views were expressed varied, Sarec's policies consistently underlined the need for local research capacity in accordance with national priorities. The policies also consistently framed local research capacity as part of a larger system nationally, regionally and internationally. In retrospect one might look at the support to individual research training or research projects as being based on linear views in comparison to the idea of supporting entire institutions. Tying back to development theories, the latter theoretically allows more local control over priorities and less micro-administration. In relation to its different historical contexts, however, Sarec's policy was consistently emancipatory or anti-colonial.

Against this backdrop and in light of the recent claims about how Swedish aid has changed from being solidarity-based to a stronger emphasis on mutual benefit and national interest, it would be interesting to study research aid, not least post-2008, with a focus on how policies have been implemented. What is research aid, how do the imaginaries and discourses "behave" and negotiate futures in the contexts of their concrete application?

998 Gaillard, J. (2003). "Tanzania: A Case of 'Dependent Science'." Science Technology Society 8(2): 317-343. pp328-329 


\section{EPILOGUE: Imagining futures post-2008}

There has been heated debate about the organization and direction of Swedish aid between 2008 and now. How should the results of aid be measured and reported? The phasing-out of aid from certain countries has been questioned, as has the increased detailed political steering of the aid organization and the closer ties to national interest that have resurfaced. ${ }^{999}$

A few turbulent years at Sida followed after 2008, and in 2010 a new strategy for research aid was put in place

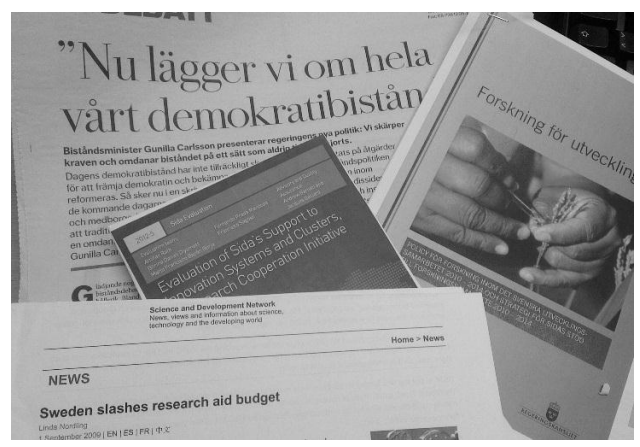

Figure 12: Media and policy documents by the government. The situation today is that the policy is very similar to its precedents concerning the task and major modes of work, but the emphasis on national systems of innovation and economic growth has been stepped up, as exemplified by the quote below:

A country's allocated resources to research is mirrored in international publications and patents which in turn correlate with the amount of researchers, research centres such as universities and institutes, libraries and laboratories as well as the level of strategic research planning. [...] Research is an important component in the development of what we call the "knowledge society." In this lies an interplay between research and society in general; a so-called innovation system. ${ }^{1000}$

The research function at Sida has been through a few reorganizations during this period as well, and is now called the Unit for Research Cooperation, staffed by around fifteen people. There are also nine research secretaries in other parts of the organization, including embassies in partner countries. ${ }^{1001}$ The budget for research aid has fluctuated during the period after 2008, but is now back to around one billion crowns. Roughly $50 \%$ of this goes to international organizations and $50 \%$ to bilateral and regional

\footnotetext{
999 Odén, B. and L. Wohlgemuth (2013). Swedish Development Cooperation Policy in an International Perspective, School of Global Studies, University of Gothenburg. 1000 (2009). Strategi för Sidas stöd till forskningssamarbete 2010 - 2014. Utrikesdepartementet. p7

10017 at embassies in low-income countries and 2 at Sida's department of programme cooperation (PROGSAM) who cooperate with the Unit for Research Cooperation. The amount of staff working on research aid in 2013 are almost $50 \%$ fewer than in 2008 according to the current head of unit Anders Granlund. Transcription Interview with Anders Granlund 032013. pp1-2
} 
cooperation. ${ }^{1002}$ Support to Swedish development research ( $u$-forsk) was taken over by Vetenskapsrådet (the Swedish Research Council). According to an evaluation from 2012 by development researchers Måns Fellesson and Mats Hårsmar, this was because Sida's Unit for Research Cooperation did not have enough resources to manage this programme anymore. ${ }^{1003}$ In sum, it would appear that capacity in terms of research staff at Sida has been reduced considerably while the tasks and goals have remained the same. ${ }^{1004}$

1002 Sida. (2013). Retrieved December, 2013, from http://www.sidaresearch.se/researchcooperation.aspx. and Transcription Interview with Anders Granlund 032013. pp1-2 1003 Fellesson, M. and M. Hårsmar (2012). "Review of Sida's Programme for Development Research. Evaluation of "U-forsk", 2006-2012." pp10-11

1004 My ambition with the epilogue initially was to delve a little deeper into the recent years' media debate about Swedish aid and the policy developments within research aid between 2008 and 2013, but that will have to wait! 


\section{Appendix A}

\section{Intervjuguide}

\section{Några bakgrundsfrågor}

- Skulle du kunna säga ditt namn och nuvarande befattning?

- Vad gjorde du innan \& hur kom det sig att du började arbeta på Sarec?

- Hur länge jobbade du där innan du blev chef?

\section{Sarecs utveckling under den tid du jobbade samt var chef där}

- Kan du berätta lite om hur du tycker att Sarec förändrades under den tid du jobbade där?

- Vilka har varit de viktigaste orsakerna till dessa förändringar?

- Kan du berätta lite om sammanslagningen mellan Sida, Sarec, BITS o Swedecorp 1995 ?

\section{Sambandet mellan forskning/forskningskapacitet och} utveckling/fattigdomsbekämpning?

- Hur ser du på sambandet? Fanns det olika uppfattningar om detta under din tid på Sarec?

De svenska universitetens och högskolornas roll i forskningssamarbetet - förutsättningar och incitament

- Hur ser du på de svenska universitetens och högskolornas roll i forskningssamarbetet?

- Hur utvecklades/förändrades deras engagemang under den tid du var chef?

\section{Forskningsbiståndets utveckling på 2000-talet}

- Forskningspropositioner, policy för global utveckling, Parisagendan,

- Andra forskningsbiståndsaktörer/ökat antal aktörer internationellt.

- EU-nivån: stöd till utvecklingsrelevant forskning

- Utvärderingarna 2006

- Omorganisationen 2008

- Utmaningar för framtiden

Har du något annat du skulle vilja tillägga? Får jag återkomma om jag har fler frågor? 


\section{Interview guide}

\section{Some background questions}

- Could you state your name and current occupation?

- What were you doing before, and how come you started working at Sarec?

- How long were you there before you became director?

Sarecs development during the time you were there and was director?

- Can you tell me about how you think Sarec developed during the time you were there?

- What were the most important reasons for this development?

- Can you tell me about the merger of Sida, Sarec, BITS and Swedecorp 1995?

The relationship between research/research capacity and development/poverty reduction?

- What do you think about the connection? Were there different views on this during your time at Sarec?

The Swedish universities role in research aid - preconditions and incentives

- How do you view the role of Swedish universities in research aid?

- How did their involvement develop/change during the time you were director?

The development of research aid in the 2000's

- Research bills, Policy for global development, the Paris Agenda

- Other research aid actors, the increased amount of actors

- The EU-level: support for development relevant research

- The evaluations from 2006

- The reorganization of 2008

- Future challenges

Do you have anything else to add? May I return if I have further questions? 


\section{References}

A Global Perspective on Research and Development (2009), UIS Fact Sheet, No. 2-09, UNESCO Institute for Statistics.

(1975). Regeringens proposition med förslag till statsbudget för budgetåret 1975/76

(1979). Förordning med instruktion för styrelsen för u-landsforskning (Swedish Agency for Research Cooperation with Developing Countries, SAREC). 1979:832.

Riksdagen. Svensk författningssamling.

(1979). Proposition 1978/79:113 om riktlinjer för u-landsinformation och biståndets organisation m.m. Utrikesdepartementet.

(1985). Tio år med Sarec. En utvärdering av SARECs verksamhet med särskild tonvikt på de bilaterala insatserna (Ds UD 1985:2). Utrikesdepartementet.

(1988). Förordning (1988:532) med instruktion för styrelsen för u-landsforskning (SAREC). D. o. F. Affairs.

(1990). Regeringens proposition 1989/90:90 om forskning.

(1993). Regeringens proposition 1992/93:244 - Om styrnings- och samarbetsformer i biståndet.

(1994). Motion 1993/94:U214, Biståndssamverkan rörande högre utbildning.

(1994). Utrikesutskottet betänkande 1993/94:UU15 Internationellt utvecklingssamarbete.

(1995). Regeringens proposition 1994/95:100 - Förslag till statsbudget för budgetåret $1995 / 1996$

(1999). The 10/90 Report on Health Research. G. F. f. H. Research. Geneva.

(2000). Higher Education in Developing Countries - Perils and Promise. The Taskforce on Higher Education and Society. T. W. Bank.

(2000). Regeringens proposition 2000/01:3 Forskning och förnyelse.

(2002). Regeringens proposition 2002/03:122. Gemensamt ansvar: Sveriges politik för global utveckling.

(2004). Regeringens proposition 2004/05:80 Forskning för ett bättre liv.

(2008). Ett lyft för forskning och innovation. Regeringens proposition 2008/09:50. T. S. Government.

(2008). Regeringens proposition 2008/09:50 Ett lyft för forskning och innovation.

(2009). Strategi för Sidas stöd till forskningssamarbete 2010 - 2014. Utrikesdepartementet.

Alatas, S. F. (2003). "Academic Dependency and a Global Division of Labour in the Social Sciences, Current Sociology, Vol.51." Current Sociology 51(6): 599-613.

Altbach, P., G. (2004). "Globalization and the University: Myths and Realities in an Unequal World." Tertiary Education and Management(10:1).

Altbach, P., G. (2007). "Peripheries and Centres: Research Universities in Developing Countries." Higher Education Management and Policy 19(2): 106-130.

Altbach, P., G. and J. Knight (2007). "The Internationalization of Higher Education: Motivations and Realities." Journal of Studies in International Education 11(3-4): 290-305

Amin, S. (1975). "New Forms of Collaboration in Development Research and Training." International Social Science Journal XXVII(4): 790 - 795.

Ampofo, A. A., J. Beoku-Betts, et al. (2004). "Women's and Gender Studies in EnglishSpeaking Sub-Saharan Africa. A Review of Research in the Social Sciences." Gender \& Society 18(6): 685-714. 
Andersson, B. (1991). Imagined Communities: Reflections on the Origin and Spread of Nationalism, Verso books.

Andersson, C., L. Heikensten, et al. (1984). Bistånd i kris. En bok om svensk ulandspolitik, Liber förlag.

Andersson, W. (2002). "Introduction: Postcolonial Technoscience." Social Studies of Science 32(5-6): 643-658.

Andersson, W. (2009). "From subjugated knowledge to conjugated subjects: science and globalization, or postcolonial studies of science?" Postcolonial Studies: culture, politics, economy 12(4): 389-400.

Angeles, L. and P. Boothroyd (2003). "Canadian Universities and International Development: Learning from Experience." Canadian Journal of Development Studies 24(1): 9-26.

Annerstedt, J. and A. Jamison (1986). Science and Technology for Development Scandinavian efforts to foster development research and transfer resources for research and experimental development to developing countries. UNESCO.

Appadurai, A. (1996). Modernity at large - cultural dimensions of globalization, University of Minneapolis Press.

Appadurai, A. (2000). "Grassroots Globalization and the Research Imagination." Public Culture 12(1): 1-19.

Arndt, C., S. Jones, et al. (2009). Aid and Growth - Have We Come Full Circle? . Discussion Paper No 2009/05, United Nations University World Institute for Development Economics Research.

Asingwire, N., S. Kyomuhendo, et al. (2008). Sida's Support to the Agency for Cooperation and Research in Development (ACORD) to the HIV and AIDS Support and Advocacy Programme (HASAP) in Uganda.

Baaz Eriksson, M. (2005). The Paternalism of Partnership, Zed Books.

Babb, S. (2003). "The Social Consequences of Structural Adjustment: Recent Evidence and Current Debates." Annual Review of Sociology 31: 199-222

Baldamus, W. (1972). The Role of Discoveries in Social Sciences. The Rules of the Game. T. Shanin. London, Tavistock Publications.

Banzon Bautista, M. C. R., L. Velho, et al. (2001). Comparative study of the impacts of donor-initiated programmes on research capacity in the South The Hague, Ministry of Foreign Affairs/Directorate-General for Development

Cooperation, the Netherlands

Bauchspies, W. and V. Gyberg Brodén (2013). Decolonization of Science and Technology: Why?, About Time!, or Impossible. 4S. San Diego.

Behar, J. and M. Lundahl (1994). Now's the time. An evaluation of the Swedish development with Nicaragua, Secretariat for analysis of Swedish Development Assistance (SASDA).

Benner, M. (2008). Kunskapsnation i kris. Politik, pengar och makt i svensk forskning, Nya Doxa.

Bergman, P., B. Berner, et al. (2005). Samhällsvetenskapens hantverk, Arkiv förlag.

Berthelemy, J.-C. (2005). Bilateral donor's interest vs. recipients' development motives in aid allocation: do all donors behave the same? The Political Economy of Aid. Hamburg

Bhagavan, M. R. (1992). The SAREC model: institutional cooperation and the strengthening of national research capacity in developing countries. Stockholm, SAREC. 
Biccum, A. R. (2005). "Development and the 'New' Imperialism: a reinvention of colonial discourse in DFID promotional literature." Third World Quarterly 26(6): 10051020.

Bigsten, A. (1975). Om u-landsforskningsutredningens forskningsbegrepp. Ekonomisk debatt, Nationalekonomiska Föreningen. 2.

Bigsten, A. (1984). Ekonomisk utveckling i fattiga länder. En teoriöversikt. Ekonomisk Debatt, Nationalekonomiska Föreningen. 1.

Birdsall, N. (2008). Seven Deadly Sins: Reflections on Donor Failings. Reinventing Foreign Aid. W. Easterly, MIT Press.

Blagescu, M. and J. Young (2006). Capacity Development for Policy Advocacy: Current thinking and approaches among agencies supporting Civil Society Organisations, ODI: 56.

Boeren, A., T. Alberts, et al. (2006). Sida/SAREC Bilateral Research Cooperation: Lessons Learned. Sida Evaluation 06/17.

Boshoff, N. (2009). "Neo-colonialism and research collaboration in Central Africa." Scientometrics 81(2): 413-434.

Bowen, G. A. (2006). "Grounded Theory and Sensitizing Concepts." International Journal of Qualitative Methods 5(3).

Bradley, M. (2007). On the agenda: North-South research partnerships and agendasetting processes International Development Research Centre (IDRC).

Bradley, M. (2008). "On the agenda: North-South research partnerships and agendasetting processes." Development in Practice 8(8).

Braun, D. and D. Guston (2003). "Principal-agent theory and research policy: an introduction." Science and Public Policy

30(5): 302-308.

Brodén, V. (2012). "Aiding research capacity for development: tensions and dilemmas." International Journal of Contemporary Sociology 49(1): 117-144.

Brodin, A. (2000). Getting politics right : democracy promotion as a new conflict issue in foreign aid policy Doctoral thesis, University of Gothenburg.

Brundenius, C., B.-Å. Lundvall, et al. (2009). The role of universities in innovation systems in developing countries: Developmental University Systems - Empirical, Analytical and Normative Perspectives. Handbook of Innovation Systems and Developing Countries - Building Domestic Capabilities in a Global Setting. B.-Å. Lundvall, K. J. Joseph and C. e. Chaminade, Edward Elgar Publishing.

Burnside, C. and D. Dollar (2000). "Aid, Policies, and Growth." The American Economic Review 90(4).

Burnside, C. and D. Dollar (2004). Aid, Policies, and Growth: Revisiting the Evidence, World Bank Policy Research Working Paper 3251.

Bäckstorp, A.-L. (2007). When the first world goes local. Education and gender in postrevolution Laos, Umeå University.

Bäckstrand, K. and E. Lövbrand (2007). Modernization and Civic Environmentalism. The Social Construction of Climate Change: Power, Knowledge, Norms, Discourses. M. E. Pettenger, Ashgate Publishing.

Carlsson, G. (2007). The New Development Cooperation (ppt), The Prime Minster's Office and the Ministry of Foreign Affairs.

Chataway, J., J. Smith, et al. (2005). Partnerships and Building Capabilities for Science, Technology, Innovation and Development in Africa, The Open University, Research Centre on Innovation. Knowledge and Development. 
Chouliaraki, L. and N. Fairclough (1999). Discourse in Late Modernity. Rethinking Critical Discourse Analysis, Edinburgh University Press.

Cogneau, D. and J.-D. Naudet (2005). "Who Deserves Aid? Equality of Opportunity, International Aid and Poverty Reduction." World Development 35(1).

Coleman, J. S. (1986). "The idea of the developmental university." Minerva 24(4): 476494.

Collier, D., F. D. Hidalgoa, et al. (2006). "Essentially contested concepts: Debates and applications." Journal of Political Ideologies 11(3): 211-246.

Cornwall, A. (2007). "Buzzwords and fuzzwords: deconstructing development discourse." Development in Practice Vol 17:4(4): 471-484

Costello, A. and A. Zumla (2000). "Moving to research partnerships in developing developing countries." British Medical Journal (BMJ) 321(September): 827-829.

Court, J. and S. Maxwell (2005). "Policy entrepreneurship for bridging poverty reduction: Bridging research and policy in international development." Journal of International Development 17: 713-725.

Cozzens, S. E., R. Hagendijk, et al. (2007). Research Summary 3: A Framework for Analyzing Science, Technology and Inequalities: Preliminary Observations.

Craig, D. and D. Porter (2003). "Poverty Reduction Strategy Papers: A New Convergence." World Development 31(1): 53-69.

Dahdouh Guebas, F., J. Ahimbisibwe, et al. (2003). "Neo-colonial science by the most industrialised upon the least developed countries in peer-reviewed publishing " Scientometrics 56(3): 329-343.

Dahlman, C. and T. e. Vishwanath (1999). World Development Report 98/99: Knowledge for Development, The World Bank.

Danemark, B., M. Ekström, et al. (2002). Explaining Society: Critical Realism in the Social Sciences, The Cromwell press.

de Laet, M. and A.-M. Mol (2000). "The Zimbabwe Bush Pump: Mechanics of a Fluid Technology." Social Studies of Science 30(2): 225-263

Deiaco, E., A. Högberg, et al. (2006). SARECs stöd till svensk u-landsforskning.

Dreyfus, H. L. and P. Rabinow (1983). Michel Foucault. Beyond Structuralism and Hermeneutics (2nd ed), The University of Chicago Press.

Drucker, P. F. (1969). The Age of Discontinuity - Guidelines to Our Changing Society, Harper and Row.

DsUD1985:2 (1985). Tio år med Sarec. En utvärdering av SARECs verksamhet med särskild tonvikt på de bilaterala insatserna Utrikesdepartementet.

DsUD1986:1 (1986). Sarec - The First Decade, The Ministry of Foreign Affairs.

Duque, R. B., M. Ynalvez, et al. (2005). "Collaboration Paradox: Scientific Productivity, the Internet, and Problems of Research in Developing Areas." Social Studies of Science 35(5): 755-785.

Easterly, W. (2005). "What did structural adjustment adjust? The association of policies and growth with repeated IMF and World Bank adjustment loans, ." Journal of Development Economics 76: 1-22.

Edgerton, D. (2004). The "Linear Model" Did not Exist. Reflections on the History and Historiography of Science and Research in Industry in the Twentieth Century The Science-Industry Nexus. History, Policy, Implications. K. Grandin, N. Wormbs and S. Widmalm, Science History Publications/USA \& The Nobel Foundation.

Edqvist, 0. (2006). Sidas U-landsforskningsråd.

Edqvist, O. (2009). Gränslös forskning, Nya Doxa.

Eduards, K. (2006). Review of Sida's Research Cooperation. Synthesis Report. 
Eklund, M. (2007). Adoption of the Innovation System Concept in Sweden, Uppsala University.

Elzinga, A. (1995). "Traces of Eurocentrism in Current Representations of Science." VEST 8(4): 85-96.

Elzinga, A. (2004). "Metaphors, models and reification in science and technology policy discourse." Science as Culture 13(1): 105-121.

Elzinga, A. (2004). The New Production of Reductionism in Models Relating to Research Policy. The Science-Industry Nexus. History, Policy, Implications. K. Grandin, N. Wormbs and S. Widmalm, Science History Publications/USA \& The Nobel Foundation.

Elzinga, A. and B. Wittrock (1985). The University Research System. The Public Policies of the Home of Scientist, Almqvist \& Wiksell International.

Enemark, S. (2005). Capacity Building for Higher Education in Developing Countries - A Part of the Western World University Portfolio? Capacity Building in Higher Education and Research on a Global Scale. Copenhagen UNESCO.

Etzkowitz, H. and L. Leydesdorff (2000). "The dynamics of innovation: from National Systems and "Mode 2" to a Triple Helix of university-industry-government relations." Research Policy 29.

Etzkowitz, H. and L. Leydesdorff (2000). A Triple Helix of University-IndustryGovernment Relations: »Mode 2 « and the Globalization of »National« Systems of Innovation, in "Science under pressure" The Danish Institute for Studies in Research and Research Policy

Fairclough, N. (1993). Discourse and Social Change, Polity Press.

Fairclough, N. (2003). Analysing Discourse - Textual Analysis for Social Research, Routledge.

Fairclough, N. (2010). Critical Discourse Analysis - The Critical Study of Language (2nd ed), Longman.

Fallenius, A.-M. (1996). Research Capacity Building in Developing Countries. International Scientific Cooperation. Paris.

Featherstone, M., S. Lash, et al. (1995). Global Modernities, SAGE Publications.

Fellesson, M. and M. Hårsmar (2012). "Review of Sida's Programme for Development Research. Evaluation of "U-forsk", 2006-2012."

Felt, U. (2013). Keeping Technologies Out: Sociotechnical imaginaries and the formation of a national technopolitical identity. Pre-Print, University of Vienna.

Fisher, E. and D. Holland (2003). "Social development as knowledge building: research as a sphere of policy influence." Journal of International Development 15(7): 911-924.

Forster, J. and O. e. Stokke (1999). Policy Coherence in Development Cooperation, Frank Cass \& Co. Ltd.

Foucault, M. (1972). The Archaeology of Knowledge \& the Discourse on Language, Tavistock Publications.

Foucault, M. (1977). Nietzsche, Genealogy, History. Language, Counter-Memory, Practice M. Foucault, Basil Blackwell.

Foucault, M. (1980). Questions of Method. Michel Foucault: Power. J. D. Faubion, The New Press: 223-238.

Frank, D. J. and J. W. Meyer (2007). "University expansion and the knowledge society." Theory and Society 36(4): 287-311.

Fruhling, P. (1990). Kunskap som förändrar. Resultat av forskningsbiståndet, Berlings. 
Gaillard, J. (1990). "Science in the developing world: foreign aid and national policies at a crossroad." Ambio 19: 348-353.

Gaillard, J. (2003). "Tanzania: A Case of 'Dependent Science'." Science Technology Society 8(2): 317-343.

Galis, V. and A. Hansson (2012). "Partisan Scholarship in Technoscientific Controversies: Reflections on Research Experience." Science as Culture 21(3): 335-364.

Gibbons, M., C. Limoges, et al. (1994). The New Production of Knowledge - The Dynamics of Science and Research in Contemporary Societies, SAGE Publications.

Giere, R. N. (2006). Scientific Perspectivism University of Chicago Press

Globkom (2002). En ny svensk politik för global utveckling (SOU 2001:96). ,.

Godin, B. (1998). "Writing Performative History: The New New Atlantis? ." Social Studies of Science 28(3): 465-483.

Godin, B. (2005). "The Linear Model of Innovation: The Historical Construction of an Analytical Framework." Science Technology Human Values 31(6): pp659-660.

Goonatilake, S. (1993). Modern Science and the Periphery. The "Racial" Economy of Science. S. Harding, The University of Indiana Press: 259-267.

Graham, L. J. (2005). Discourse analysis and the critical use of Foucault. Australian Association for Research in Education. Sydney.

Gramsci, A. (1971). Selections from the Prison Notebooks, International Publishers.

Greenberg, A. and A. Muchanga (2006). Evaluation of Sida Information and Communications Technology Support to Universities. Sida Evaluation 06/13.

Guston, D. (1999). "Stabilizing the Boundary between US Politics and Science: The Role of the Office of Technology Transfer as a Boundary Organization." Social Studies of Science 29(1): 87-111

Guston, D. (2001). "Boundary Organizations in Environmental Policy and Science: An Introduction." Science, Technology, \& Human Values 26(4): 399-408.

Göransson, B., R. Maharajh, et al. (2009). "Introduction: New challenges for universities beyond education and research." Science and Public Policy 36(2): 83-84.

Hajer, M. (1995). The politics of environmental discourse: Ecological modernization and the policy process, Clarendon Press.

Hajer, M. and H. Wagenaar (2003). Deliberative Policy Analysis- Understanding Governance in the Network Society Cambridge University Press.

Hamilton, C. (1977). Slutreplik till professor KE Knutsson. Ekonomisk debatt, Nationalekonomiska föreningen.

Hamilton, C. (1977). Vem styr användningen av Sarecs forskningspengar? Ekonomisk Debatt, Nationalekonomiska föreningen.

Hansen, H. and F. Tarp (2000). "Aid Effectiveness Disputed." Journal of International Development 12: 375-398.

Harding, S. (1998). Is Science Multicultural? Postcolonialisms, Feminisms and Epistemologie, Indiana University Press.

Harding, S. (1999). The Racial Economy of Science: Toward a Democratic Future Indiana University Press.

Harding, S. (2008). Sciences from Below- Feminisms, Postcolonialisms, and Modernities, Duke University Press.

Harris, E. (2004). Building scientific capacity in developing countries. EMBO reports VOL 5:1 7-11.

Healey, P., S. E. Cozzens, et al. (2008). Review Report: Policy Issues and Options in ResIST and the CARE model. 
Hettne, B. and K. E. Knutsson (1974). Tvärvetenskap eller ämnesimperialism i ulandsforskningen? Ekonomisk debatt, Nationalekonomiska Föreningen. 6.

Holland, D. G. (2006). Socializing knowledge: The production and circulation of social science in Malawi, 1964--2004, University of Pennsylvania.

Holland, D. G. (2009). "Between the Practical and the Academic: The Relation of Mode 1 and Mode 2 Knowledge Production in a Developing Country " Science, Technology and Human Values 34(5).

Hollanders, H. and L. Soete (2010). The UNESCO Science Report 2010. The Current Status of Science Around the World UNESCO: Executive Summary.

Holmberg, J. (1992). Future Food Needs, International Agricultural Research and the Role of SAREC, Sarec.

Horton, D. (2003). Evaluating capacity development experiences from research and development organizations around the world. The Hague :, ISNAR ;.

Hounsell, D. A. (2004). Industry Research. The Science-Industry Nexus. History, Policy, Implications. K. Grandin, N. Wormbs and S. e. Widmalm, Science History Publications/USA \& The Nobel Foundation.

Howarth, D. (2000). Discourse, Open University Press.

Howitt, P. (2004). Endogenous Growth, Productivity and Economic Policy: A Progress Report. International Productivity Monitor 3-15.

Hwang, K. (2008). "International Collaboration in Multilayered Center-Periphery in the Globalization of Science and Technology." Science Technology Human Values 33(1): 101-133.

Jamison, A., S. Hyldgaard Christensen, et al. (2011). A Hybrid Imagination. Science and Technology in Cultural Perspective, Morgan \& Claypool.

Jasanoff, S. (2006). States of Knowledge: The Co-production of Science and the Social Order, Routledge.

Jasanoff, S. and K.-S. Kim (2013). "Sociotechnical Imaginaries and National Energy Policies." Science as Culture 22(2): 189-196.

Jasanoff, S. and S.-H. Kim (2009). "Containing the Atom: Sociotechnical Imaginaries and Nuclear Power in the United States and South Korea." Minerva 47(2): 119-146.

Jasanoff, S. and M. Long Martello (2004). Earthly Politics, The MIT Press.

Johansson de Château, L. and S. Billfalk (2007). Building Research Partnerships - an evaluation of the Swedish Research Links programme.

Jolly, R., L. Emmerij, et al. (2004). UN contributions to development thinking and practice, Indiana University Press.

Jones, N., M. Bailey, et al. (2007). Research capacity strengthening in Africa Trends, gaps and opportunities, Overseas Development Institute (ODI).

Jörgensen, M. and L. Phillips (2002). Discourse Analysis as Theory and Method, Sage publications.

Kenny, S. and M. Clarke (2010). Challenging capacity building: comparative perspectives rethinking international development Palgrave Macmillan

King, K. (2004). Development Knowledge and the Global Policy Agenda. Whose Knowledge? Whose Policy? Occasional Paper, . UNRISD Social Knowledge and International Policy-making: Can Research Make a Difference? Centre of African Studies, University of Copenhagen

King, K. and S. McGrath (2004). Knowledge for Development? Comparing British, Japanese, Swedish and World Bank Aid. New York, Zed Books Ltd. 
Kjellqvist, T. (2013). Biståndspolitikens motsägelser om kunskap och tekniköverföring från konkret praktik till abstrakt policy. doctoral dissertation series, Blekinge Institute of Technology.

Knutsson, K. E. (1977). Användningen av Sarecs forskningspengar. Replik till Carl Hamilton. Ekonomisk debatt Nationalekonomiska föreningen.

Koopman, C. (2009). Two uses of genealogy: Michel Foucault and Bernard Williams. Foucault's Legacy. C. G. Prado, Continuum International Publishing.

Krishna, V. V., R. Waast, et al. (2002). "The Changing Structure of Science in Developing Countries." Science, Technology and Society 5(2).

Kvale, S. and S. Brinkmann (2009). Den kvalitativa forskningsintervjun, Studentlitteratur.

Lancaster, C. (2006). Foreign Aid: Diplomacy, Development, Domestic Politics, The University of Chicago Press.

Laredo, P. (2007). "Revisiting the Third Mission of Universities: Toward a Renewed Categorization of University Activities?" Higher Education Policy 20: 441-456.

Lenefors, L., L. Gustafsson, et al. (2006). Sida Evaluation 06/22, Organisationsstudie av SAREC.

Levidow, L. and T. Papaioannou (2013). "State imaginaries of the public good: shaping UK innovation priorities for bioenergy." Environmental Science and Policy 30: 36-49.

Limpach, S. and K. Michaelowa (2010). The Impact of World Bank and IMF Programs on Democratization in Developing Countries. CIS working paper No. 62 Center for Comparative and International Studies, ETH Zurich and University of Zurich.

Litfin, K. (1994). Ozone Discourse: Science and Politics in Global Environmental Cooperation.

Loomba, A. (2005). Colonialism/Postcolonialism. The New Critical Idiom (2nd ed), Routledge.

Loots, E. (2006). "Aid and Development in Africa: The Debate, The Challenge and The Way Forward." South African Journal of Economics 74(3).

Lundahl, M. (1981). Teorins plats inom utvecklingsekonomin. Ekonomisk Debatt, Nationalekonomiska Föreningen. 8.

Lundahl, M. (1985). Bör utvecklingsforskningen vara tvärvetenskaplig? Ekonomisk debatt, Nationalekonomiska föreningen. 2.

Lundahl, M. and B. Södersten (1974). U-landsforskningen. Replik till Hettne och Knutsson. Ekonomisk debatt, Nationalekonomiska Föreningen. 7.

Lusthaus, C., M.-H. Adrien, et al. (1999). Capacity Development: Definitions, Issues and Implications for Planning, Monitoring and Evaluation. Universalia Occasional Paper. 35.

MacKenzie, D., F. Muniesa, et al., Eds. (2007). Do Economists Make Markets? On the Performativity of Economics, Princeton University Press.

Mamdani, M. (2007). Scholars in the Market Place. The Dilemmas of Neoliberal Reform at Makerere University 1989-2005, the Council for the Development of Social Science Research in Africa (CODESRIA).

Marcus, G. (1995). Technoscientific Imaginaries: Conversations, Profiles, and Memoirs, University of Chicago Press.

Melander, F. (2006). Lokal forskningspolitik. Institutionell dynamik och organisatorisk omvandling vid Lunds universitet 1980-2005, Lund University.

Menon, V. and K. N. Nair (2002). Capacity Building for Demand-led Research: Issues and Priorities Maastricht: European Centre for Development Policy Management. 
Merson, J. (2000). "Bio-prospecting or Bio-piracy: Intellectual Property Rights and Biodiversity in a Colonial and Postcolonial Context." Osiris 15(282-296).

Miettinen, R. (2002). National Innovation System. Scientific concept or political rhetoric?, Edita.

Mills, S. (2003). Discourse, Routledge.

Mirowski, P. and E.-M. Sent (2008). The Commercialization of Science and the Response of STS. The Handbook of Science and Technology Studies (3rd ed). E. J. Hackett, 0. Amsterdamska, M. Lynch and J. Wajcman, the MIT Press: 636-637.

Moreno, E. and T. Alveteg (2003). Collaboration between Sweden and the Public Universities of Nicaragua Sida evaluations 03/31, Sarec.

Mosley, P., J. Hudson, et al. (2004). "Aid, Poverty Reduction and the New Conditionality." The Economic Journal 114.

Mowery, D. C. and B. N. Sampat (2005). Universities in National Innovation Systems The Oxford handbook of innovation. J. Fagerberg, D. C. Mowery and R. R. e. Nelson, Oxford University Press.

Moyo, D. (2009). Dead Aid. Why Aid Is Not Working and How There Is a Better Way for Africa, Farrar, Straus and Giroux.

Mulkay, M. (1979). Science and the Sociology of Knowledge, Allen \& Unwin.

Nederveen-Pieterse, J. (2010). Development Theory (2nd ed), Sage Publications.

Nederveen-Pieterse, J. (2011). "Discourse analysis in international development studies." Journal of Multicultural Discourses 6(3): 237-240.

Nilsson, R. (2006). Foucault - en introduktion, Egalité.

Nowotny, H. (2004). Does History of Science Have Policy Implications? The Science Industry Nexus. History, Policy, Implications. K. Grandin, N. Wormbs and S. Widmalm, Science History Publications/USA \& The Nobel Foundation.

Nowotny, H., P. Scott, et al. (2001). Re-thinking science: knowledge in an age of uncertainty, Polity Press.

Odén, B. (2006). Biståndets idéhistoria: från Marshallhjälp till millenniemål. Lund, Studentlitteratur.

Odén, B. and L. Wohlgemuth (2013). Swedish Development Cooperation Policy in an International Perspective, School of Global Studies, University of Gothenburg.

OECD (2012). Innovation for Development. A discussion of the issues and an overview of work of the OECD Directorate for science, technology and industry.

Ofori-Adjei, D. and J. Gyapong (2007). A Developing Country Perspective on International Research Partnerships on Health, Centre for Tropical Clinical Pharmacology, University of Ghana Medical School College of Health Sciences, Accra, Ghana Health Research Unit, Ghana Health Service.

Ogbu, O. (2006). The demand for policy research in Africa. Science and Technology Policy for Development: Dialogues at the Interface. L. Box and R. e. Engelhard, Anthem Press.

Olsson, B. (1992). The Ownership and Cultivation of Knowledge. The rationale for Swedish support to universities in developing countries. Sarec.

Openaid.se. (2013). "Sveriges totala bistånd." Retrieved 102213, from www.openaid.se.

Ordóñez-Matamoros, G., S. E. Cozzens, et al. (2011). North-South and South-South Research Collaboration: What Differences Does It Make For Developing Countries? - The Case of Colombia. Atlanta Conference on Science and Innovation Policy

Philip, K., L. Irani, et al. (2012). "Postcolonial computing - a tactical survey." Science Technology Human Values 37(1): 3-29. 
Pickersgill, M. (2011). "Connecting neuroscience and law: anticipatory discourse and the role of sociotechnical imaginaries." New Genetics and Society 30(1): 27-40.

Priebe, G. (2010). Att afrikanisera vetenskaplig kunskap. MIM och malariaforskningen i ett postkolonialt dilemma, Göteborgs universitet.

Radelet, S., M. Clemens, et al. (2004). Counting Chickens when they hatch: The shortterm effect of aid on growth Working paper \#44, Center for Global Development.

Radelet, S., M. Clemens, et al. (2005). Aid and Growth. Finance and Development, IMF. 42.

Rath, A., G. Björklund, et al. (2006). SAREC Support to International and Regional Thematic Research Programs 2000-2005. Individual reports and cases.

Rath, A., G. Björklund, et al. (2006). SAREC Support to International and Regional Thematic Research Programs 2000-2005. Main report.

Regeringskansliet (1979). Förordning (1979:832) med instruktion för styrelsen för ulandsforskning (Swedish Agency for Research Cooperation with Developing Countries, SAREC). Utrikesdepartementet.

ResIST. (2006). "Researching inequality through science and technology." Retrieved 110713, from http://www.resist-research.net/home.aspx.

Restivo, S. and W. Bauchspies (1997). "How to criticize science and maintain your sanity." Science as Culture 6(3): 396-413.

Retriever Sverige, A. Retrieved December, 2013, from http://www.mynewsdesk.com/se/retriever/pressreleases/download/resource_ attached_pdf_document/884760.

Riksrevisionen (2009). Sida's support for capacity development in the public administration of partner countries. RiR:2009:15

Rostow, W. (1959). "The stages of economic growth." The Economic History Review, New Series 12(1): 1-16.

Ryan, G. W. and R. H. Bernard (2003). "Techniques to Identify Themes." Field Methods 15(1).

Rydén, B. (1984). Bistånd under omprövning, Studieförbundet Näringsliv och Samhälle.

Said, E. W. (1978). Orientalism, Vintage books.

Sandberg, S., Ed. (1992). Uppbrott. Om u-länder, bistånd och solidaritet inför sekelskiftet. En debattantologi, Svensk Volontärsamverkan.

Sanyal, B. C. and N. V. Varghese (2007). Research Capacity of the Higher Education Sector in Developing Countries, International Institue for Educational Planning, UNESCO.

Sarec (1977). Sarec's First Year, Annual Report 1975/1976.

Sarec (1979). Sarec Annual Report 1978/1979.

Sarec (1979). Sarec's Second Year, Annual Report 1977/1978.

Sarec (1979). Sarec's Third Year, Annual Report 1977/1978.

Sarec (1980). Sarec Annual Report 1979/1980.

Sarec (1981). Sarec Annual Report 1979/1980.

Sarec (1982). Sarec Annual Report 1980/1981.

Sarec (1983). Sarec Annual Report 1981/1982.

Sarec (1983). Sarec Annual Report 1982/1983.

Sarec (1984). Sarec Annual Report 1983/1984.

Sarec (1985). Sarec Annual Report 1983/1984.

Sarec (1986). Sarec Annual Report 1984/1985.

Sarec (1987). Sarec Annual Report 1986/1987.

Sarec (1988). Sarec Annual Report 1987/1988. 
Sarec (1989). Sarec Annual Report 1988/1989.

Sarec (1990). Sarec Annual Report 1989/1990.

Sarec (1992). Sarec Annual Report 1990/1991.

Sarec (1993). Sarec Annual Report 1991/1992.

Sarec (1994). Sarec Annual Report 1992/1993.

Sarec (1995). Research for Development. Sarec 20 years Kristianstads boktryckeri.

Sarec (1995). Sarec Annual Report 1993/1994.

Sarec $(1998,2000)$. Research Cooperation I. An Outline of Policy, Programmes and Practice, Sida.

Sarec $(1998,2000)$. Research Cooperation II. Trends in Development Research, Sida.

Sawyerr, A. (2004). "African Universities and the Challenge of Research Capacity

Development1." Journal of Higher Education in Africa 2 (1): 213-242.

Schedvin, T. (2006). Översyn av verksamhetsgrenen forskning: sammanställning av rekommendationer, Sida.

Schott, T. (1998). "Ties between center and periphery in the scientific world system: Accumulation of rewards, dominance and self-reliance in the center." Journal of World Systems Research 4(2): 112-144.

Schumpeter, J. (1934). The Theory of Economic Development, Harvard University Press. Schumpeter, J. (1942). Capitalism, Socialism and Democracy, George Allen \& Unwin.

Selby, J. (2007). "Engaging Foucault: Discourse, Liberal Governance and the Limits of Foucauldian IR." International Relations 21(3): 324-345.

Seth, S. (2009). "Putting knowledge in its place: science, colonialism, and the postcolonial." Postcolonial Studies 12(4): 373-388.

Shaobo, X. (1997). "Rethinking the Problem of Postcolonialism." New Literary History 28(1): 7-19.

Shapin, S. (2008). Science and the Modern World Handbook of Science and Technology Studies (3rd ed). E. J. H. e. a. (eds), The MIT Press.

Shepherd, C. J. (2006). "From In Vitro to In Situ: On the Precarious Extension of Agricultural Science in the Indigenous 'Third World'." Social Studies of Science 36(3): 399-426.

Shinn, T. (2002). "The Triple Helix and New Production of Knowledge: Prepackaged, Thinking on Science and Technology." Social Studies of Science 32(4): 599-614.

Shinn, T., J. Spaapen, et al. (1996). Science and Technology in a Developing World, Kluwer Academic Publishers.

Shove, E. (2003). "Principals, agents and research programmes." Science and Public Policy 30(5): 371-381.

Sida-Sarec (1999). A Sea of Opportunities. Research Cooperation 1998.

Sida-Sarec (2001). Science for Development - Searching for Keys to the Future. Research Cooperation 2000.

Sida-Sarec (2002). Towards Freedom from Poverty. Research Cooperation 2001.

Sida-Sarec (2004). Research Cooperation 2003. Forging Links.

Sida-Sarec (2005). Research Cooperation 2004. Research Makes Sense.

Sida-Sarec (2006). Letter to the Swedish Ministry of Foreign Affairs. Summary and comments regarding the evaluations published in 2006.

Sida-Sarec (2006). Yearbook 2005. Research Capacity. Towards the Millennium Goals.

Sida. "From funding research to fighting poverty." Retrieved October, 2010, from http://www.sida.se/English/Partners/Universities-and-research/From-fundingresearch-to-fighting-poverty/.

Sida (1997). Sida årsredovisning 1995/1996. 
Sida (2000). Capacity Building - Sida Working Paper No 4. Analysis of Needs for Capacity Development. , Department for Natural Resources and the Environment, Policy Secretariat for the Sector Departments.

Sida (2000). Sida's Policy for Capacity Development a Strategic Question in Development Cooperation

Sida (2003). Environmental Research Challenges in Developing Countries - some reflections. Future Environmental Research, Environment Policy Division and Sarec.

Sida (2005). Innovation Systems in Latin America. Examples from Honduras, Nicaragua and Bolivia.

Sida (2005). Manual for Capacity Development.

Sida (2006). Biotechnology and the Future of Africa. A presentation of the BIO-EARN Programme.

Sida (2006). Time for Rethinking. Capacity Development in a Changing Landscape of Development Cooperation.

Sida (2006). Årsredovisning.

Sida (2007). Årsredovisning.

Sida (2008). Resultatbilaga till Sidas årsredovisning 2008.

Sida. (2009). "Zambiska Dambisa Moyo utmanar biståndet." Retrieved January, 2011, from http://www.sida.se/Svenska/Nyhetsarkiv/2009/Maj/Zambiska-DambisaMoyo-utmanar-bistandet/.

Sida. (2013). Retrieved December, 2013, from http://www.sidaresearch.se/researchcooperation.aspx.

Sieber, P. and T. Braunschweig (2005). Choosing the Right Projects. Designing Selection Processes for North-South Research Programmes, KFPE

Simon, H. A. (2000). "Bounded Rationality in Social Science: Today and Tomorrow." Mind \& Society 1: 25-39.

Sismondo, S. (2010). An Introduction to Science and Technology Studies (2nd ed), WileyBlackwell.

Smith-Doerr, L. A. and J. B. Croissant (2011). "A feminist approach to university-industry relations: Integrating theories of gender, knowledge, and capital." Journal of Women and Minorities in Science and Engineering 17(3): 251-269.

Smith, E. (2009). "Imaginaries of Development: The Rockefeller Foundation and Rice Research." Science as Culture 18(4): 461-482.

Sogge, D. (2002). Give and Take? What's the Matter with Foreign Aid? , Zed Books.

SOU1973:41 (1973). Forskning för utveckling. Betänkande av ulandsforskningsutredningen. Statens offentliga utredningar. Stockholm.

Standke, K.-H. (1997). Overview of past multilateral Conferences on Science and Technology. Third Meeting of the Steering Committee of the International Scientific Advisory Board of UNESCO. UNESCO.

Star, S. L. and J. Greisemer (1989). "Institutional Ecology, 'Translations' and Boundary Objects: Amateurs and Professionals in Berkeley's Museum of Vertebrate Zoology, 1907-39." Social Studies of Science 19(3): 387-420.

Stehr, N. (2005). Knowledge Politics: Governing the Consequences of Science and Technology., Paradigm Publishers.

Stirling, A. (2009). "Direction, Distribution and Diversity! Pluralising Progress in Innovation, Sustainability and Development." The STEPS Centre. 
Stokke, O. (1989). Western Middle Powers and Global Poverty. The Determinants of the Aid Policies of Canada, Denmark, the Netherlands, Norway and Sweden, the Scandinavian Institute of African Studies.

Strauss, C. (2006). "The Imaginary." Anthropological Theory 6(3): 322-344

Sundin, P., B. Göhl, et al. (2008). The Asian Regional Research Programme on Environmental Technologies (ARRPET).

Swantz, M. L. and M. A. Tripp (1996). Development for big fish or for small fish?: A study of contrasts in Tanzania's fishing sector. Decolonising Knowledge from Development to Dialogue. F. Apffel-Marglin and S. A. Marglin, Clarendon Press.

Svensson, J. (1999). "Aid, Growth and Democracy." Economics and Politics 11(3).

Svensson, J. (2001). Foreign Aid: Does it Work? Can it Work? Report to the Committee on Sweden's Policy for Global Development (Globkom).

Södersten, B. and M. Lundahl (1974). Forskning för utveckling. Ekonomisk debatt, Nationalekonomiska Föreningen. 2.

Taylor, C. (2004). Modern Social Imaginaries, Duke University Press.

Thulstrup, E., W. (1998). "Evaluation of Research Capacity Building in the Third World." Knowledge, Technology \& Policy 10(4): 90-101.

Thörn, Å. (2008). Vem ger verkligheten namn? Om forskningsbistånd och blinda fläckar, Hjalmarsson och Högberg.

Transcription Interview with Anders Granlund 032013.

Transcription (2009). Interview with Berit Olsson 092509.

Transcription (2010). Interview with Anders Wijkman 042910.

Transcription (2010). Interview with Bo Bengtsson 101011.

Transcription (2010). Interview with Lars Anell 032210.

Transcription (2010). Interview with Tomas Kjellqvist 100110.

Transcription (2013). Interview with Björn Hettne 020513.

Transcription (2013). Interview with Johan Holmberg 021413.

Transcription (2013). Interview with Rolf Carlman 032013.

Traweek, S. (1988). Beamtimes and lifetimes: The world of high energy physicists, Harvard University Press.

Triantafillou, P. (2012). New Forms of Governing. A Foucauldian Inspired Analysis, Palgrave Mcmillan.

UN. "The UN Millenium Goals." Retrieved March, 2013, from www.un.org/millenniumgoals/.

UNESCO. "Higher Education Section "Some general trends and Challenges" " Retrieved February, 2011, from http://portal.unesco.org/education/en/ev.php-

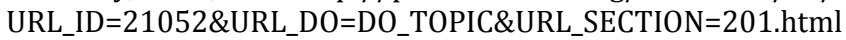

UNESCO (2004). A Decade of Investment in Research and Development (R\&D): 1990 2000 UIS Bulletin on Science and Technology Statistics Issue No. 1-04. U. I. f. Statistics.

UNESCO (2005). Towards Knowledge Societies.

UNESCO (2005). What do Bibliometric Indicators tell us about World Scientific Output? . UIS Issue No. 2-05. U. I. o. Statistics.

UNESCO (2009). A Global Perspective on Research and Development (2009). UIS Fact Sheet No. 2-09. U. I. f. Statistics.

Wade, R. (2013). "The Art of Power Maintenance. How Western States Keep the Lead in Global Organizations." Challenge 56(1).

Wagner, C. S., I. T. Brahmakulam, et al. (2001). Science and Technology Collaboration: Building Capacity in Developing Countries?, The World Bank. 
Wagner, C. S. and L. Leydesdorff (2005). "Network structure, self-organization, and the growth of international collaboration in science." Research Policy 34(10): 16081618.

van Audenove, L. (1998). "Development cooperation and linkages in higher education: Key issues concerning policy and organisation." International Review of Education 44 (5/6).

van de Sande, T. (2006). Priority Setting in Research For Development: A Donor Perspective. Science and Technology Policy for Development: Dialogues at the Interface. L. Box and R. Engelhard, Anthem Press.

Watson, R., M. Crawford, et al. (2003). Strategic Approaches to Science and Technology in Development. World Bank Policy Research Working Papers, The World Bank.

Weiler, H. N., S. Guri-Rosenblit, et al. (2006). Universities as Centres of Research and Knowledge Creation: An Endangered Species? Summary report from Colloquium on Research and Higher Education UNESCO.

Velho, L. (2004). "Research Capacity Building for Development: From Old to New Assumptions." Science Technology Society 9(2): 171-207.

Velho, L. (2006). Building a critical mass of researchers in the least developed countries: new challenges. Science and Technology Policy for Development, Dialogues at the Interface. L. Box and R. Engelhard, Anthem Press.

Veltmeyer, H. (2005). "Development as Globalization as Imperialism." Canadian Journal of Development Studies xxxvi(1).

Whyte, A. (2004). Landscape Analysis of Donor Trends in International Development. Human and Institutional Capacity Building. t. R. Foundation.

Widstrand, C. and J. Valdelin (1990). An Evaluation of the Bilateral Institutional Research Co-operation supported by Sarec.

Winner, L. (1986). The Whale and the Reactor: a Search for Limits in an Age of High Technology., University of Chicago Press.

Wodak, R. and M. Meyer (2009). Methods of Critical Discourse Analysis (2nd ed), Sage publications.

Woolgar, S. and B. Latour (1979). Laboratory Life: The Social Construction of Scientific Facts, Sage Publications.

Worldmapper. "Map 205, "Science Research"." Retrieved August, 2010, from www.sasi.group.shef.ac.uk/worldmapper/.

Worldmapper. "Map 206, "Science Growth", accessed in August 2010." Retrieved August, 2010, from www.sasi.group.shef.ac.uk/worldmapper/.

Ynalvez, M. A. and W. M. Shrum (2009). "International Graduate Science Training and Scientific Collaboration." International Sociology 24(6): 870-901.

Young, J. and N. Kannemeyer (2001). Building Capacity in Southern Research: A Study To Map Existing Initiatives. O. D. I. (ODI).

Ziman, J. (1996). "Post-academic Science': Constructing Knowledge with Networks and Norms." Science Studies 9(1): 67-80.

\section{Figures and tables}

Figure 1: Scientific papers published 2001

Figure 2: Fairclough's three-dimensional model p32

Figure 3: The boundary organization p63

Figure 4: Theoretical framework $\quad$ p65

$\begin{array}{ll}\text { Figure 5: Knowledge that creates change } & \text { p67 }\end{array}$ 
Figure 6: Matrix for assessing capacity development needs

Figure 7: Sida's model of capacity

Figure 8: The motivation staircase

p199

Figure 9: Research aid as portrayed by Sarec's policy

p208

Figure 10: Theoretical framework

p230

Figure 11: The boundary organization

p234

Figure 12: Media and policy documents

Table 1: Timeline

p11

Table 2: Meanings of development over time

p22

Table 3: Development perspectives and future options

p28

Table 4: Global hegemony and development theories

p30

Table 5: The discourses

p138

Table 6: The discourses II

p233 